VILNIAUS GEDIMINO TECHNIKOS UNIVERSITETAS

Vytautas BIELINSKAS

\title{
MIESTO APLEISTỤ TERITORIJŲ PASKIRTIES KEITIMO SCENARIJŲ VERTINIMAS DAUGIARODIKLIAIS SPRENDIMŲ PRIĖMIMO METODAIS
}

DAKTARO DISERTACIJA

TECHNOLOGIJOS MOKSLAI, STATYBOS INŽINERIJA (02T)

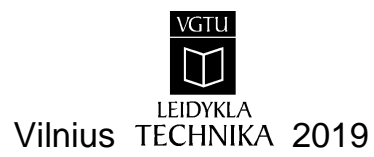


Disertacija rengta 2014-2019 metais Vilniaus Gedimino technikos universitete.

Vadovas

prof. dr. Marija BURINSKIENE் (Vilniaus Gedimino technikos universitetas, statybos inžinerija - 02T).

Vilniaus Gedimino technikos universiteto Statybos inžinerijos mokslo krypties disertacijos gynimo taryba:

\section{Pirmininkas}

prof. habil. dr. Leonas USTINOVIČIUS (Vilniaus Gedimino technikos universitetas, statybos inžinerija - 02T).

\section{Nariai:}

prof. dr. Jurgita ANTUCHEVIČIENE (Vilniaus Gedimino technikos universitetas, statybos inžinerija - 02T),

doc. dr. Rasa APANAVIČIENE (Kauno technologijos universitetas, statybos inžinerija - 02T),

prof. habil. dr. Joanicjusz NAZARKO (Balstogès technologijos universitetas, Lenkija, vadyba-03S),

doc. dr. Gintaras STAUSKIS (Vilniaus Gedimino technikos universitetas, menotyra $-03 \mathrm{H})$.

Disertacija bus ginama viešame Statybos inžinerijos mokslo krypties disertacijos gynimo tarybos posėdyje 2019 m. vasario $8 \mathrm{~d}$. 13 val. Vilniaus Gedimino technikos universiteto senato posèdžių salëje.

Adresas: Sauletekio al. 11, LT-10223 Vilnius, Lietuva.

Tel.: (8 5) 274 4956; faksas (8 5) 270 0112; el. paštas doktor@vgtu.lt

Pranešimai apie numatomą ginti disertaciją išsiųsti 2019 m. sausio 7 d.

Disertaciją galima peržiūrèti VGTU talpykloje http://dspace.vgtu.lt ir Vilniaus Gedimino technikos universiteto bibliotekoje (Saulètekio al. 14, LT-10223 Vilnius, Lietuva).

VGTU leidyklos TECHNIKA 2019-001-M mokslo literatūros knyga

http://leidykla.vgtu.lt

ISBN 978-609-476-127-0

(C) VGTU leidykla TECHNIKA, 2019

(C) Vytautas Bielinskas, 2019

vytautas.bielinskas@vgtu.lt 
VILNIUS GEDIMINAS TECHNICAL UNIVERSITY

Vytautas BIELINSKAS

EVALUATION OF SCENARIOS FOR

CHANGES IN THE PURPOSE OF URBAN BROWNFIELDS APPLYING MULTI-ATTRIBUTE DECISION MAKING METHODS

DOCTORAL DISSERTATION

TECHNOLOGICAL SCIENCES, CIVIL ENGINEERING (02T)

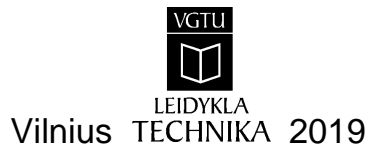


Doctoral dissertation was prepared at Vilnius Gediminas Technical University in 2014-2019.

\section{Supervisor}

Prof. Dr Marija BURINSKIENÉ (Vilnius Gediminas Technical University,

Civil Engineering - 02T).

The Dissertation Defence Council of Scientific Field of Civil Engineering of Vilnius Gediminas Technical University:

\section{Chairman}

Prof. Dr Habil. Leonas USTINOVIČIUS (Vilnius Gediminas Technical University, Civil Engineering - 02T).

\section{Members:}

Prof. Dr Jurgita ANTUCHEVIČIENE (Vilnius Gediminas Technical University, Civil Engineering - 02T),

Assoc. Prof. Dr Rasa APANAVIČIENE (Kaunas University of Technology, Civil Engineering - 02T),

Prof. Dr Habil. Joanicjusz NAZARKO (Bialystok University of Technology, Poland, Management - 03S),

Assoc. Prof. Dr Gintaras STAUSKIS (Vilnius Gediminas Technical University, History and Theory of Arts $-03 \mathrm{H}$ ).

The dissertation will be defended at the public meeting of the Dissertation Defence Council of Civil Engineering in the Senate Hall of Vilnius Gediminas Technical University at 1 p. m. on 8 February 2019.

Address: Saulètekio al. 11, LT-10223 Vilnius, Lithuania.

Tel.: +370 5274 4956; fax +370 5270 0112; e-mail: doktor@vgtu.lt

A notification on the intend defending of the dissertation was send on 7 January 2019.

A copy of the doctoral dissertation is available for review at VGTU repository http://dspace.vgtu.lt and at the Library of Vilnius Gediminas Technical University (Saulètekio al. 14, LT-10223 Vilnius, Lithuania). 


\section{Reziumè}

Disertacijoje pateikta apleistų miesto teritorijų paskirties keitimo poreikio ir vertinimo analizè. Pagrindinis darbo objektas - urbanizuotose miesto teritorijose išsidèsčiusias apleistas teritorijas apibūdinančių rodiklių sistema. Atlikus mokslinės literatūros analizę, ekspertini vertinimą ir panaudojus geografinių informacinių sistemų technologiją, sudaryta apleistas teritorijas apibūdinančių rodiklių sistema. Atlikti skaičiavimai sudare tinkamas sąlygas nustatyti reikšmingiausius rodiklius kiekvienu apleistos teritorijos paskirties keitimo scenarijaus atveju ir parinkti racionaliausias miesto dalis šiems pakeitimams iqgyvendinti, atsižvelgiant į miesto aplinką nusakančius parametrus. Pagrindinis darbo tikslas - moksliškai pagrịsti ir pasiūlyti miesto apleistų teritorijų paskirties keitimo scenarijų vertinimo modelị, kurị pritaikius galima parinkti tinkamiausią apleistų teritorijų naudojimo scenarijų.

Disertaciją sudaro ịvadas, 3 skyriai, bendrosios išvados, literatūros sąrašas, publikacijų disertacijos tema sąrašas ir 7 priedai. İvade trumpai aptariama tiriamoji problema, darbo aktualumas, aprašomas tyrimo objektas, formuojamas darbo tikslas ir uždaviniai, aprašomas mokslinis darbo naujumas, ginamieji teiginiai. Ivado pabaigoje pristatomos autoriaus paskelbtos publikacijos, pranešimai konferencijose, nurodomas dalyvavimas tarptautiniuose seminaruose ir pateikiama disertacijos struktūra. Pirmajame skyriuje pateikiama mokslinès literatūros, dokumentų ir kitų atliktų darbų disertacijos tema analizè. Išnagrinèti apleistų teritorijų sprendimo būdai, pateikiami pavyzdžiai ir ịvairūs apleistų teritorijų vertinimo principai. Antrajame skyriuje pateikta apleistų teritorijų sklaidos analizė taikant geostatistinę analizę skirtingais duomenų analizès aspektais. Nustatyti apleistų teritorijų sklaidos kiekybiniai ir kokybiniai parametrai skirtingose miesto dalyse, taip pat miesto seniūnijų skirstymo pagal svarbą sistema ir potencialūs apleistų teritorijų paskirties keitimo variantai. Pasiūlyta apleistų teritorijų pertvarkymo strategija ir igyvendinimo koncepcija, integruoti skirtingu paskirties keitimo scenarijų rinkiniai ir apibrěžti prioritetiniai jų iggvendinimo būdai. Trečiajame skyriuje pasiūlyti skaičiavimais pagrịsti apleistų teritorijų paskirties keitimo variantai. Pateiktas šiems scenarijams igyvendinti tinkamų miesto dalių atrankos modelis. Skaičiavimais pagrịstos rekomendacijos atspindètos sudarytoje apleistų teritorijų antrinio panaudojimo strategijoje.

Disertacijos tema pakelbtos septynios mokslinès publikacijos, iš kurių trys referuojamos duomenų bazès Thomson Reuters Web of Knowledge (Clarivate Analytics Web of Science) recenzuojamuose mokslo žurnaluose, dvi publikacijos pristatytos recenzuojamose tarptautinèse mokslo konferencijose ir dvi publikacijos - kitose tarptautinių ir respublikinių konferencijų leidiniuose. 


\section{Abstract}

The disseration presents the analysis and evaluation of demand for changes in land purpose in urban brownfields. The main object of thesis is a system of indicators describing the use of urban brownfields in a city. The carried-out analysis of research literature, expert evaluation and the application of technologies for geographic information systems as well as a scheme of descriptive criteria for brownfields have been proposed. The calculations made created suitable conditions for identifying the most significant criteria for each case of changes in brownfield purpose and selecting the most rational parts of the city for implementing the above-mentioned changes.

The aim of the disseration is to scientifically justify and propose a model for the assessment of urban abandoned land use change scenarios that can be used to select the most appropriate brownfield scenario. The dissertation consists of introduction, three chapters, general conclusions, the list of references, the list of author's publications on the topic of the disseration, summary in English and 7 annexes. Introduction describes the research problem and the relevance of the study, describes the subject of the research, defines the purpose and problems of the study and points out scientific novelty of the paper as well as the statements to be defended. Chapter 1 gives an overview of references, documents and other studies on this issue. The analysis of the normative documents issued in the Republic of Lithuania, the EU Member States and other countries is performed thus concentrating on the world regulating reuse of brownfields and the analysis of scientific studies. Chapter 2 deals with research on the sprawl of brownfields with reference to geostatistical analysis in terms of different aspects of cross-cutting analysis. The chapter defines quantitative and qualitative parameters for the sprawl of brownfields in different parts of the city and proposes a partition system for city neighbourhoods according to the importance and potential scenarios for brownfields. A readjustment strategy for brownfields and a concept of implementing it are proposed. The author suggests integrating different sets of scenarios for changes in land purpose and defines priority areas of implementing them. Chapter 3 provides a calculation model for scenarios concerning changes in land purpose of brownfields and explores appropriate parts of the city to implement them.

Seven scientific publications on the subject of the doctoral thesis have been published. Three of those are reported in the research journals reviewed by Thomson Reuters Web of Knowledge (Clarivate Analytics Web of Science). Two publications are presented at the reviewed international academic conferences and two publications are issued in the other proceedings of national and international conferences. 


\section{Žymëjimai}

\section{Simboliai}

$A$ - teritorijos plotas, ha;

$\alpha$ - reikšmingumo lygmuo;

$B$ - ekspertų $G$ suteiktų balų vertinimo rodikliams matrica;

$C$ - vertinimo rodiklių sistema;

$C_{E}$ - ekonominių rodiklių grupe;

$C_{j}^{*}$-TOPSIS metodu skaičiuojamas rodiklis;

$C_{m}-m$-asis AT vertinimo rodiklis;

$C_{N}-$ gamtinių rodiklių grupe;

$C_{S}$ - socialinių rodiklių grupé;

$C_{U}$ - užstatymo ir infrastruktūros rodiklių grupe;

$D_{i}-$ Vilniaus miesto $i$-toji seniūnija;

$D_{j}^{*}$ - TOPSIS metodu skaičiuojamas kiekvienas lyginamojo varianto bendras atstumas tarp geriausių sprendinių;

$E$ - periferinè Vilniaus miesto dalis;

$e_{i k}-i$-ajam rodikliui suteiktas rangas;

$F$ - miesto seniūnijų funkcinis tipas; 
$\varphi$ - vienodų rangų skaičius;

$G_{n}-n$-asis ekspertas, dalyvaujantis tyrime;

$I_{1}$ - maksimizuojamujų rodiklių indeksų aibè;

$I_{2}-$ minimizuojamujjų rodiklių indeksų aibè;

$K$ - paskirties keitimo scenarijų skaičius;

$k$ - rodikliui suteiktų rangų $e$ skaičius;

$M d$ - imties mediana;

$m$ - rodiklių skaičius;

$m_{i j}-j$-ojo objekto rodiklio vieta;

$n$ - alternatyvų skaičius;

$\operatorname{Pr}$ - seniūnijos prioritetiškumo lygis, siekiant pakeisti AT paskirtį;

$Q_{j}$ - kiekvieno rodiklio svarbos rodiklis (santykinis reikšmingumas);

$R$ - koreliacijos koeficientas;

$R n$ - AT vertinimo rodiklio rangas prioritetinèje eilutëje;

$r$-ekspertų skaičius;

$s$ - standartinė deviacija (standartinis nuokrypis); dydis, nusakantis atsitiktinio dydžio igyjamų reikšmių sklaidą apie vidurkį;

$S_{j}-\mathrm{SAW}$ metodo pasvertųų rodiklių reikšmių suma;

$S_{-j}-$ minimizuojamųų ịvertintų normalizuotų rodiklių suma;

$S_{+j}$ - maksimizuojamųjų įvertintų normalizuotų rodiklių suma;

$T$ - AT paskirties keitimo scenarijų masyvas;

$t_{\varphi}$ - vienodų rangų skaičių tarp $\varphi$ aibės;

$\omega_{i}-i$-ojo rodiklio $k$-tojo eksperto apskaičiuoti svoriai;

$\mathrm{v}$ - laisvès laipsnis;

$W$ - konkordancijos koeficientas;

$\chi^{2}$ - konkordancijos koeficiento reikšmingumas (Pirsono kriterijus);

$z$-erdvinès interpoliacijos būdu apskaičiuota nežinoma reikšmė.

\section{Santrumpos}

AT - apleista teritorija (angl. BF - Brownfield);

$\mathrm{BP}$ - bendrasis planas;

BD - didieji duomenys (angl. Big Data);

$\mathrm{BVP}$ - bendrasis vidaus produktas;

CABERNET - tinklas, vienijantis suinteresuotas šalis pagal sutartus veiksmus gaivinti apleistas teritorijas (angl. Concernet Action on Brownfield and Economic Regeneration Network); 
COPRAS - daugiarodiklio kompleksinio proporcingumo (angl. Complex Proportional Assessment of Alternatives Method) sprendimų prièmimo metodas;

DB - duomenų bazé;

DSPM - daugiarodikliai sprendimų prièmimo metodai (angl. Multiple-Attribute DecisionMaking - MADM);

EDAS - atstumo nuo vidutinio sprendimo (angl. Evaluation Based on Distance From Average Solution) vertinimo metodas;

EK - Europos Komisija;

ES - Europos Sajunga;

GIS - geografinès informacinès sistemos;

IDW - atvirkštinio atstumo vertinimo GIS metodas (angl. Inverse Distance Weighted);

JAV - Jungtinès Amerikos Valstijos;

$\mathrm{KPP}$ - koncentruotos plètros potencialo zona;

LDDC - Londono uosto teritorijų vystymo korporacija (angl. London Docklands Development Corporation);

LR - Lietuvos Respublika;

LRVPA - Liverpulio regiono vietinès partnerystès asociacija;

NT - nekilnojamasis turtas;

$\mathrm{TP}$ - transporto priemonè;

ML - kompiuterių mokymosi technika ir mokslas (angl. Machine Learning);

$\mathrm{HL}$ - hierarchinis klasterizavimas (angl. Hierarchical Clustering);

MP - mažmeninè prekyba;

ND - neigiamas atstumas (angl. Negative Distance);

PD - teigiamas atstumas (angl. Positive Distance);

SAW - paprastojo svorių sudejimo metodas (angl. Simple Additive Weighting);

$\mathrm{SP}$ - specialusis planas;

SPM - sprendimų prièmimo matrica;

TOPSIS - artumo idealiajam taškui metodas (angl. Technique for Order Preference by Similarity to Ideal Solution);

$\mathrm{TP}$ - teritorijų planavimas;

VGTU - Vilniaus Gedimino technikos universitetas;

ŽŪN - žemès ūkio naudmenos;

VRM - Vidaus reikalų ministerija.

\section{Terminai ir apibrèžtys}

Algoritmas - tai tam tikra veiksmų seka, kurią reikia atlikti norint pasiekti tam tikrą rezultatą. 
Ansktesnio naudojimo teritorija - bet kokia teritorija, kurioje buvo vykdoma nuolatinè veikla, turèjusi bendrą struktūrą, tačiau dabar nefunkcionuojanti ir neužimta.

Apleista teritorija (angl. Urban Brownfield) - miesto erdve, netekusi savo pirminès paskirties, nenaudojama jokiems miesto ir gyventojų poreikiams patenkinti ir yra nepatraukli naujoms investicijoms.

Bendrasis gėris - laisvai prieinamos gèrybės kasdieniams poreikiams tenkinti palaikant pakankamą gyvenimo kokybès lygị.

Centrinė miesto zona - miesto zona, pagal BP reglamentus priklausanti miesto centro teritorijai arba nutolusi nuo šios zonos atstumu, įveikiamu pesčiomis.

Efektyvumas - rezultato ir naudotų išteklių santykis.

Ekspertas - mokslo, meno ar kitų sričių specialistas, kviečiamas atsakyti ị specialius, su išmanoma sritimi susijusius klausimus.

Erdvinis duomenų jungimas - ryšių tarp atskirų erdvinių elementų sukūrimas per jų rodiklius.

Erdvinis duomenų siejimas - atributinių duomenų suteikimas erdveje persidengiantiems ar kitaip susaistytiems elementams.

Geokodacija - reikšmių suteikimas erdvèje esantiems elementams.

Priemiestinè miesto zona - miesto teritorijos, labiausiai nutolusios nuo miesto centro.

Rangas - hierarchijos lygmuo hierarchineje sistemoje, kurios elementus galima sudèti vienus su kitais ir dauginti iš skaičių: tarpusavyje tiesiškai nepriklausomų elementų skaičiaus.

Respondentas - asmuo, atsakinëjantis ị socialinių tyrimų anketas arba tyréjo žodžiu užduodamus klausimus.

Rudoji dėmè - apleistos teritorijos sinonimas.

Scenarijus - iš anksto suplanuota nauja teritorijos paskirtis.

Sistema - tam tikra tvarka sujungtụ komponentų visuma.

Teritorinė bendruomenė - teritoriniame vienete esančiu gyventojų grupé, kurią vienija bendri interesai ir poreikiai.

Tinkamas žemės paskirties scenarijus - visų geriausias apleistos teritorijos paskirties scenarijus pagal apibrèžtus planavimo tikslus, kuris negali būti pagerintas nè pagal vieną rodikli.

Užstatymo intensyvumas - visų pastatų antžeminès dalies patalpų bendrojo ploto sumos santykis su žemès sklypo plotu.

Vidurinė miesto zona - miesto dalis, esanti tarp miesto centro ir priemiestinès zonos.

Žalioji erdvè - viešoji erdvè, apimanti miestų parkus, rekreacines zonas, miškus ir pievas. 


\section{Turinys}

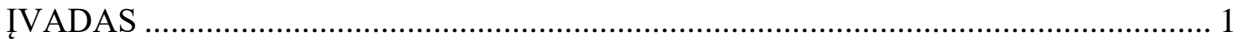

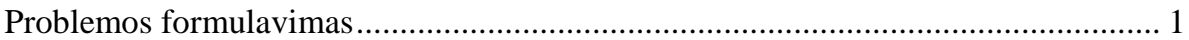

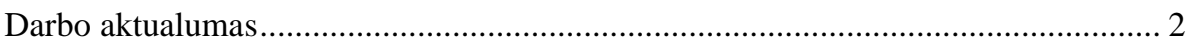

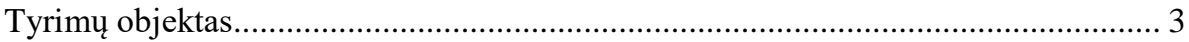

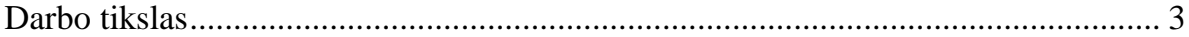

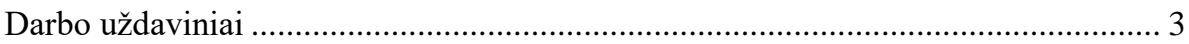

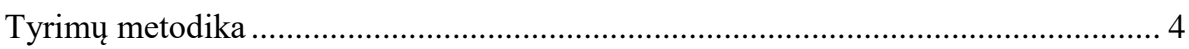

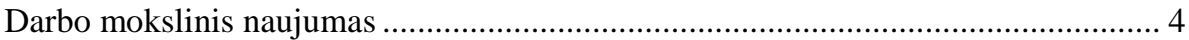

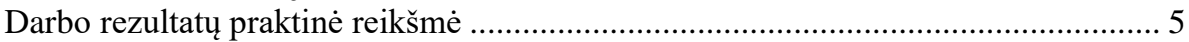

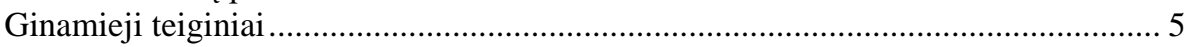

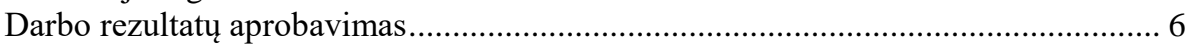

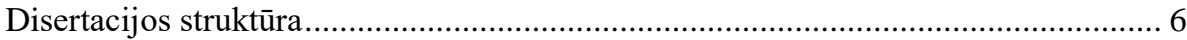

\section{APLEISTŲ TERITORIJŲ PASKIRTIES KEITIMO PROCEDŪRŲ TAIKYMO}

LIETUVOJE IR UŽSIENIO ŠALYSE APŽVALGA …………........................... 7

1.1. Apleistų teritorijų problemos kilmė ir jos atsiradimo priežastys ......................... 7

1.2. Apleistų teritorijų tipologija ir apibrěžimai skirtingose šalyse ........................... 11

1.3. Apleistų teritorijų klasterizacija taikant kompiuterinio mokymosi metodą....... 17

1.4. Apleistų teritorijų vertinimo principai. Paskirties keitimo tipai ........................ 18

1.5. Apleistų teritorijų apimties ir skaičiaus mažinimo būdai. Geroji užsienio šalių

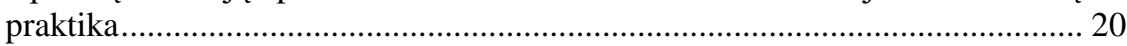

1.6. Demokratinio ir strateginio planavimo pavyzdžiai............................................ 25 
1.7. Apleistų teritorijų mastas Lietuvoje

1.8. Viešojo ir privataus sektorių partnerystès modelis, taikomas apleistų teritoriju paskirčiai keisti

1.9. Apleistų teritorijų naujos paskirties naudojimo patirtis Lietuvoje....................... 31

1.10. Pirmojo skyriaus išvados ir disertacijos uždavinių formulavimas..................... 34

2. APLEISTŲ TERITORIJŲ SKIRTINGOSE MIESTO DALYSE

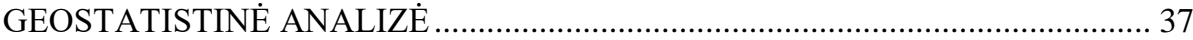

2.1. Apleistų teritorijų geostatistinès analizès planas ir metodika ............................. 37

2.2. Apleistų teritorijų kiekis ir pasiskirstymas Vilniuje ......................................... 42

2.3. Geostatistinè apleistų teritorijų analizè ir ekonominès aplinkos Liverpulio

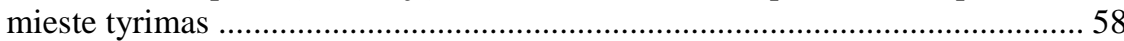

2.4. Apleistų teritorijų paskirties keitimo scenarijai .................................................. 65

2.4.1. Teorinis apleistų teritorijų Vilniaus mieste paskirties keitimo

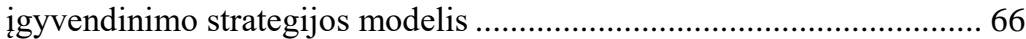

2.4.2. Apleistų teritorijų sutvarkymo koncepcijos miesto plètros strategijos

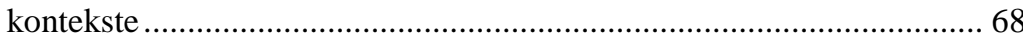

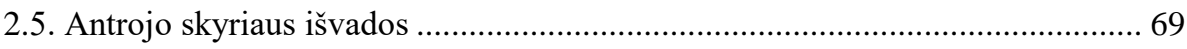

3. MIESTO APLEISTŲ TERITORIJŲ PASKIRTIES KEITIMO SCENARIJŲ

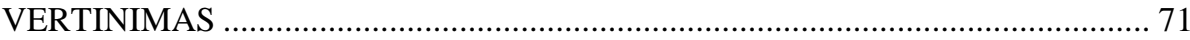

3.1. Apleistų teritorijų ir jų paskirties keitimo scenarijų vertinimo algoritmas ......... 71

3.2. Apleistų teritorijų vertinimo rodiklių sistemos sudarymo būdas ir jo taikymas 72

3.2.1. Ekspertinio vertinimo tvarka................................................................. 75

3.2.2. Svarbiausių apleistų teritorijų ankstyvujų ir alternatyviųų rodiklių

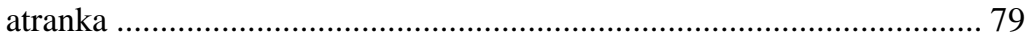

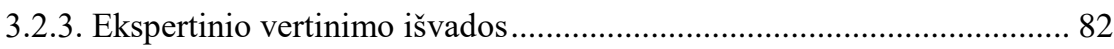

3.3. Erdvinè koreliacinè analizè, padedanti nustatyti priežastinį ryšị tarp apleistų teritorijų vertinimo rodiklių ir jų apimties seniūnijose ................................... 83

3.3.1. Erdvinès koreliacinès analizės modelis ................................................. 83

3.3.2. Erdvinès koreliacinès analizès rezultatai................................................. 85

3.4. Apleistų teritorijų paskirties keitimo scenarijų vertinimas ................................. 87

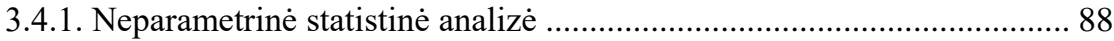

3.4.2. Svarbiausių rodiklių nustatymas skirtingų apleistų teritorijų paskirties keitimo scenarijų atvejais..................................................................... 91

3.4.3. Gautų rezultatų apžvalga ir vertinimas................................................... 94

3.5. Tinkamų miesto dalių atranka, siekiant ịgyvendinti apleistų teritorijų paskirties

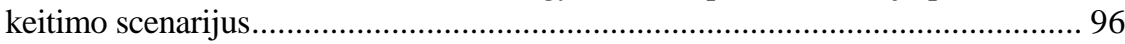

3.5.1. Daugiarodiklių sprendimų prièmimo metodų taikymas apleistų teritorijų žemès paskirties scenarijams vertinti miesto seniūnijose......... 98

3.5.2. Tinkamų seniūnijų parinkimo apleistų teritorijų žemès paskirties scenarijams igyvendinti rezultatai.

3.5.3. Tinkamų seniūnijų parinkimo konkrečiam apleistos teritorijos paskirties keitimo scenarijui rezultatų kokybinis vertinimas 106 
3.5.4. Apleistų teritorijų paskirties keitimo scenarijų iggyvendinimo strategija ir reglamentavimas

3.5.5. Integruoti skirtingų apleistų teritorijų paskirties keitimo scenarijų deriniai pagal planavimo pobūdị.

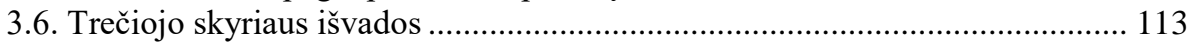

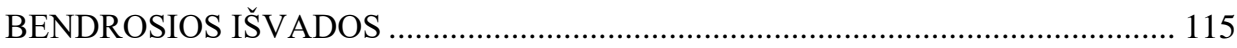

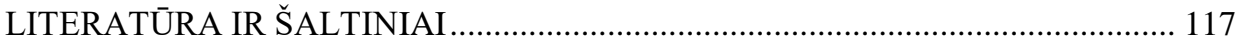

AUTORIAUS MOKSLINIŲ PUBLIKACIJŲ DISERTACIJOS TEMA

SĄRAŠAS

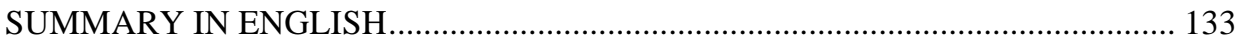

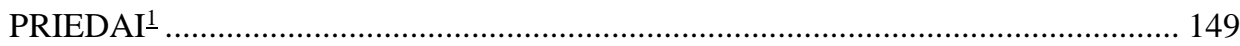

A priedas. Apleistų teritorijų automatizuotos klasterizacijos pagal

apibrèžtus rodiklius algoritmo Python programinis kodas

B priedas. Apleistų teritorijų ankstyvujjų vertinimo rodiklių ekspertinio vertinimo rezultatai

$\mathrm{C}$ priedas. Apleistų teritorijų rodiklių ekspertų vertinimo duomenys prieš

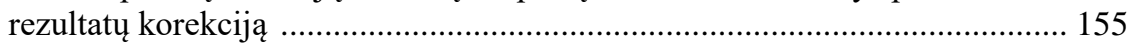

D priedas. Daugiarodiklių sprendimo prièmimo metodų vertinimo duomenys ..... 158

E priedas. Autoriaus sąžiningumo deklaracija ...................................................... 165

F priedas. Bendraautorių sutikimai teikti publikacijoje skelbtą medžiagą

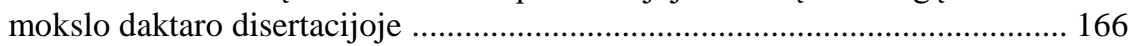

$\mathrm{G}$ priedas. Autoriaus mokslinių publikacijų disertacijos tema kopijos ................... 172

${ }^{1}$ Priedai pateikiami pridètoje elektroninèje laikmenoje. 



\section{Contents}

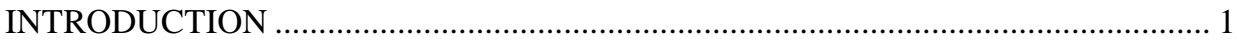

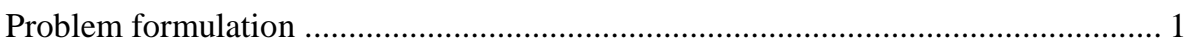

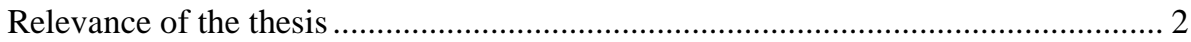

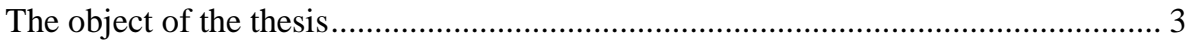

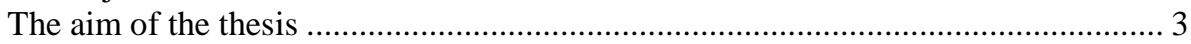

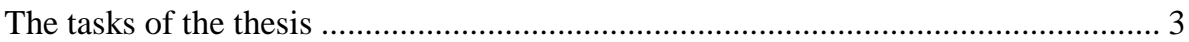

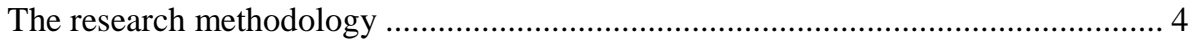

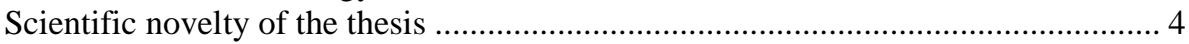

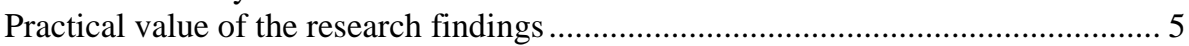

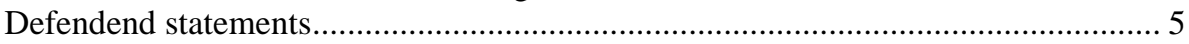

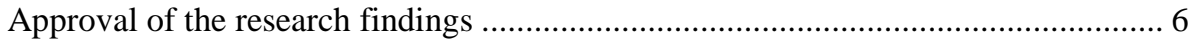

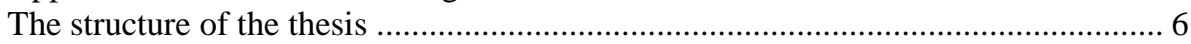

1. THE OVERVIEW OF THE PROCEDURES OF CHANGING PURPOSE OF BROWNFIELDS IN LITHUANIA AND FOREIGN COUNTRIES......................... 7

1.1. The origin of the brownfield problem and the causes of its occurence ............... 7

1.2. The typology and definitions of the brownfield in different countries ............... 11

1.3. Clustering brownfields applying machine learning method .............................. 17

1.4. The principles of brownfield assessment. Types of changing the purpose

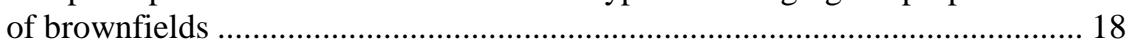

1.5. Ways of reducing the volume and number of brownfields. Good practice

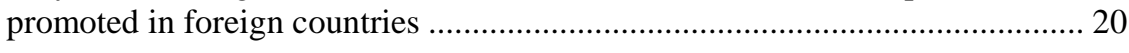


1.6. The examples of democratic and strategic planning......................................... 25

1.7. The extend of brownfields in Lithuania ............................................................ 26

1.8. A Public-Private Sector Partnership model employed for changes in the

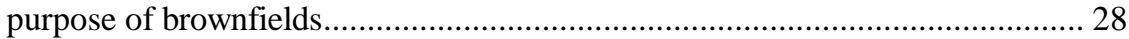

1.9. The experience of new use of brownfields in Lithuania..................................... 31

1.10. The first chapter conclusions and tasks formulation of the thesis ................... 34

2. GEOSTATISTICAL ANALYSIS OF BROWNFIELDS IN DIFFERENT

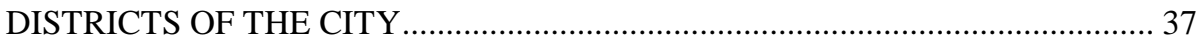

2.1. The plan and methodology for the geostatistical analysis of brownfields ......... 37

2.2. The amount and dispersion of brownfields in Vilnius city ............................... 42

2.3. The geostatistical analysis of brownfields and a study on the economic

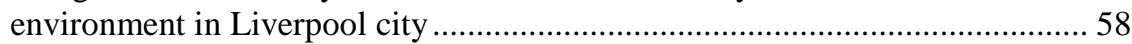

2.4. Scenarios for changes in the purpose of brownfields ........................................ 65

2.4.1. A theoretical model for implementing the strategy for changes in the

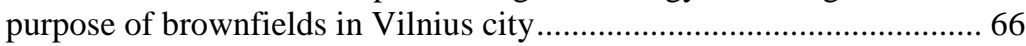

2.4.2. The concepts of brownfield management in the context of urban

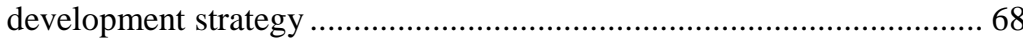

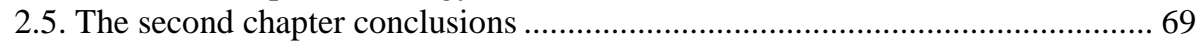

3. THE ASSESSMENT OF SCENARIOS FOR CHANGES IN THE PURPOSE OF URBAN BROWNFIELDS...................................................................... 71

3.1. An algorithm for assessing scenarios for changes in the purpose

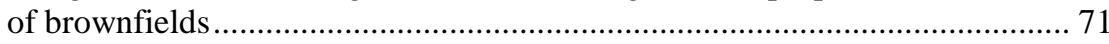

3.2. A method of building-up a system for brownfield assessment criterions

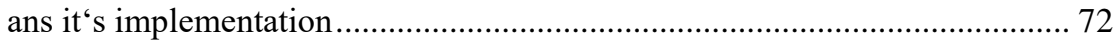

3.2.1. Procedure for expert evaluation ..................................................... 75

3.2.2. The selection of the most significant prior and alternative criteria for

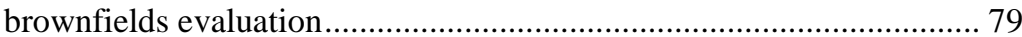

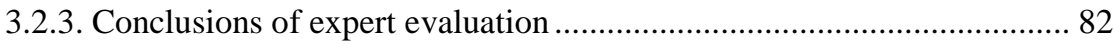

3.3. Spatial correlation analysis determining a causal relationship between criteria for brownfield assesment and their extend in the neighbourhoods ....... 83

3.3.1. A model for spatial correlation analysis .................................................. 83

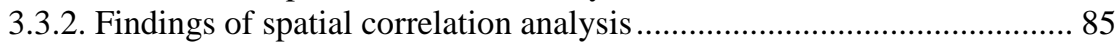

3.4. Assessing scenarios for changes in the purpose of brownfields ..................... 87

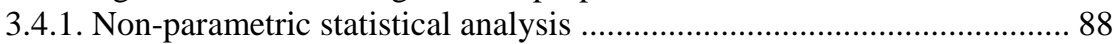

3.4.2. Determination of the most significant criteria in the cases of scenarios for changes in the purpose of different types of brownfields.... 91

3.4.3. Review and assessment of findings...................................................... 94

3.5. Selection of appropriate parts of the city for implementing scenarios for changes for changes in the purpose of brownfields .......................................... 96

3.5.1. The application of mutli-attribute decision-making methods for assessing brownfield land use scenarios in city neighbourhoods .......... 98

3.5.2. The results of selection of appropriate neighborhoods for land use scenarios for urban brownfields 
3.5.3. The qualitative assessment of the results of selecting the best neighbourhood considering a specified scenario for changes in the purpose of the brownfield ................................................................. 106

3.5.4. The strategies and regulations for implementing scenarios for changes in the purpose of brownfields

3.5.5. Integrated combinations of scenarios for changes in the purpose of different types of brownfields according to the nature of planning ..... 112

3.6. The third chapter conclusions

GENERAL CONCLUSIONS

REFERENCES

THE LIST OF SCIENTIFIC PUBLICATIONS BY THE AUTHOR ON THE

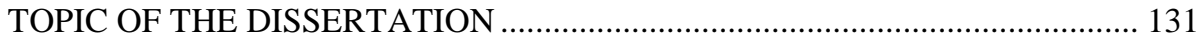

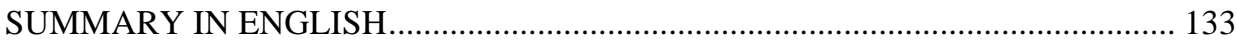

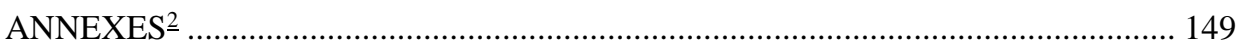

Annex A. The Python programming code of the algorithm for the defined criteria of automated clustering of brownfields.

Annex B. The finding of expert data evaluation of the initial assessment criteria for brownfields

Annex C. Data on assessing criteria for brownfields before the revised results of expert evaluation

Annex D. Data on validating methods for multi-attribute decision making ........... 158

Annex E. Declaration of academic integrity .................................................. 165

Annex F. The co-authors' agreements to present publications material in the doctoral dissertation defense

Annex G. Copies of scientific publications by the author on the topic of the dissertation

${ }^{2}$ The annexes are supplied in the enclosed compact disc. 



\section{Ivadas}

\section{Problemos formulavimas}

Viena aktualiausių problemų, su kuria susiduriama planuojant urbanistinę miesto aplinką, naujas statybas ir gyventojų poreikius atitinkančias teritorijas, yra apleistų teritorijų (toliau - AT) vertinimas ir naudojimas. Lietuvoje ir Rytų Europos šalyse AT dažnai laikomos sovietinio režimo palikimu. Tokia teritorija dèl galimų papildomų finansinių išteklių, skirtų jai išvalyti ir paruošti naudoti, dažnu atveju yra nepatraukli investuotojams.

Europos miestai per ịvairius istorinius laikotarpius susidūrè su teritorijų regeneracijos problemomis. Jas sprendžiant reikšmingą įtaką turèjo gamtinis miesto karkasas ir viešujų erdvių sistemos formavimas (Garcia-Ayllon 2018; Urbonaitė 2012). Lietuvoje, palyginti su kitomis Europos šalimis, pasigendama kompleksinio architektų, savivaldybių, miestų planuotojų požiūrio ị miesto plètros procesus, jos darnumą ir ekologiškumą (Mekdjian 2018; Sassi et al. 2009).

Planuojant miesto plètrą ir tvarkybą, dažnai sprendžiamos problemos, susijusios su AT, nebenaudojamomis pagal paskirtį (Matulevičius, Šliogerienė 2011). Vilniaus BP iki 2015 m. (Vilniaus miesto savivaldybès... 2007) sprendiniuose numatytos teritorijos, kuriose būtų vykdomas paskirties keitimas, sudaro 614 ha, t. y. 1,53\% viso miesto ploto (Leitanaite 2007). Centrineje miesto dalyje tokios teritorijos sudaro apytikriai 120 ha (Blotnys 2013). 
Tarp Lietuve galiojančių teisès aktu ir reglamentų pasigendama AT sutvarkymą apibrěžiančių normų ir rekomendacijų. Apžvelgus informacinius Lietuvos ir užsienio šaltinius, galima teigti, kad pagrindinè problema yra AT neapibrèžtumas. Vienareikšmiškai neapibrèžus šio termino, neįmanoma objektyviai nustatyti šių teritorijų potencialo, nustatyti galimų pavojų ir teikti argumentuotų sprendinių.

Apibrèžus AT, tikslinga nustatyti objektyvius rodiklius su jų savaisiais svoriais (koeficientais). Šių rodiklių skaitinè išraiška padètų ịvertinti galimų AT paskirties keitimo scenarijų potencialą, būtinumą ir prioritetiškumą (Laprise et al. 2018). Teritorijų paskirties keitimo objektai yra visa viešoji infrastruktūra miesto aplinkoje: kelių ir gatvių, atskirų transportinių, gyvenamųjų, pramoninių ir kitokios paskirties rajonų ar atskirų teritorinių vienetų reorganizacinis planavimas, jo reglamentavimas ir igyvendinimas.

\section{Darbo aktualumas}

Miestai nėra statiška baigtinè forma. Miestui, kaip urbanistiniam vienetui, būdingas ịvairialypių kūrybinių procesų vyksmo tęstinumas ekonominiu, socialiniu ir ekologiniu aspektais. Šių komponentų darna lemia ne tik gyvenimo kokybę, bet ir formuoja miestiškos aplinkos estetikos bruožus. Socioekonominių, sociokultūrinių ir geoekologinių dimensijų kaita sudaro amžiną ciklą, kurio indikatorius yra miestiška aplinka (Griškevičiūtè-Gečienè, Griškevičienė 2016; Mozuriunaite 2016). Todèl, siekiant išvengti lokalių ir globalių ekonominių, kultūrinių ir ekologinių pavojų, gyventojų ir miesto poreikius tenkinanti miesto teritorijų kaita yra neišvengiamas procesas.

Tarptautinis požiūris ị AT sprendimo būdus brendo daugiau kaip 40 metų - nuo 1970 m., kai AT naudojimo klausimas tapo svarbus politinèje dienotvarkejje. Dabar šie būdai glaudžiai susieti su darnaus miestų bei regionų vystymo strategija ir turi būti taikomi pagal šiandienos normas ir pakitusią urbanistinę aplinką.

Užsienio šalių patirtis parodè, kad socialiniai lūžiai vyksta kartu su ekonominiais (Navratil et al. 2013). Dèl ekonominių veiksmų poveikio susiformavusios AT sukèlè erdvinị darbo jègos pasiskirstymo disbalansą. Šị reiškinị iliustruoja socialinès rizikos veiksniai, aplinkos kokybè ir ekologiniai rodikliai (Keller 2011; Muličęk et al. 2014). Vakaru šaliu praktika rodo, kad šie rodikliai dažnai padeda investuotojams priimti sprendimus dẻl investavimo šiose teritorijose, siekiant pakeisti jų paskirti ir pritaikant jas konkretiems tikslams pasiekti (Rizzo et al. 2015). Todèl teritorijų pertvarkymą racionalu nagrinèti kaip socialinę, ekonominę ir teritorinę sistemą (Del Sasso, Caliandro 2010).

Ypatingo dėmesio reikalauja apleistos teritorijos pramoninès paskirties miesto zonose, kurios yra pažeidžiamiausios ekologiniu požiūriu. Tokių teritorijų 
pritaikymas šiuolaikiniams poreikiams tenkinti leistų sumažinti urbanizuojamų teritorijų plètros mastą, saugotų gamtos išteklius.

Vilniaus mieste šiuo metu yra daugiau nei 1200 AT plotų. Vilniaus miesto administracinèse ribose iš viso šie plotai užima daugiau kaip 1090 ha, t. y. maždaug $2,7 \%$ visos miesto teritorijos. Tokie plotai turi būti vertinami kaip neišnaudotas miesto išteklius, galintis pagerinti gyvenimo ir daugiasluoksnès miesto aplinkos kokybę.

\section{Tyrimų objektas}

Tyrimų objektas - urbanizuotose miesto teritorijose išsidèsčiusias apleistas teritorijas apibūdinančių rodiklių sistema.

\section{Darbo tikslas}

Darbo tikslas - moksliškai pagrịsti ir pasiūlyti miesto apleistų teritorijų paskirties keitimo scenarijų vertinimo modelị, kurị pritaikius galima parinkti tinkamiausią apleistų teritorijų naudojimo scenarijų.

\section{Darbo uždaviniai}

Darbo tikslui pasiekti darbe reikia spręsti šiuos uždavinius:

1. Atlikti literatūros analizę, kurios tikslas - nustatyti Lietuvos ir užsienio šalių apleistų teritorijų naudojimo pavojus, jų sprendimo, panaudojimo būdus ir apibendrinti sąvokas.

2. Taikant geografines informacines sistemas (GIS) ir statistinius metodus sukurti apleistų teritorijų savybes apibūdinančių rodiklių skaitinių reikšmių duomenų bazę (DB).

3. Naudojantis sudaryta duomenų baze, nustatyti svarbiausius rodiklius skirtingiems AT paskirties keitimo scenarijų atvejams.

4. Apskaičiuoti apleistų teritorijų kiekybinius parametrus taikant daugiarodiklius sprendimų prièmimo metodus (DSPM). Remiantis šiais skaičiavimais, sudaryti apleistų teritorijų paskirties keitimo igyvendinimo scenarijus. 
5. Sudarytus apleistų teritorijų scenarijus pritaikyti ir patikrinti konkrečiose Vilniaus miesto seniūnijų teritorijose.

\section{Tyrimu metodika}

Darbe taikyti mokslinès teorinès analizès, ekspertinis, erdvinès koreliacinès analizės, daugiarodiklių sprendimo prièmimo (TOPSIS, SAW, COPRAS, DELFI, EDAS), kiekybiniai ir erdvinių duomenų jungimo bei siejimo metodai.

Taikant mokslinès analizès metodą, atlikta mokslinès literatūros, Europos Komisijos leidinių, teisinių šaltinių ir nekilnojamojo turto plètotojų medžiagos disertacijos tema apžvalga.

Taikant natūrinių tyrimų metodą, nustatytas Vilniaus miesto apleistų teritorijų skaičius, dydis ir savybès. Taikant erdvinių duomenų siejimo ir jungimo metodus, papildyta apleistų teritorijų geoerdvinių duomenų bazé, apskaičiuoti apleistų teritorijų vertinimo rodikliai, taikant skirtingus normalizacijos variantus.

Geostatistinis metodas taikytas naudojant GIS programinę ịrangą ArcMap 10.0 ir Python programavimo kalbą.

Taikant VGTU mokslininkų sukurtus ir patobulintus daugiarodiklius sprendimų prièmimo metodus, mokslinëje literatūroje pristatomą ekspertinio vertinimo metodo taikymo atvejus, yra apskaičiuoti apleistų teritorijų rodikliai ir jų svoriai. Remiantis DSPM (TOPSIS, SAW, COPRAS, DELFI ir EDAS) ịvertintas apleistas teritorijas apibūdinančių rodiklių tarpusavio ryšys ir paskirties keitimo scenarijams ịgyvendinti jų daroma ịtaka. Pritaikius šiuos metodus, pasiūlyta miesto seniūnijų atrankos strategija, kurios tikslas - atrinkti tinkamiausias miesto dalis konkretiems paskirties keitimo scenarijams igyvendinti.

\section{Darbo mokslinis naujumas}

Rengiant disertaciją, buvo gauti šie nauji statybos inžinerijos mokslo rezultatai:

1. Parengta apleistų teritorijų vertinimo rodiklių sistema, kurią galima naudoti miesto strateginio planavimo etape.

2. Taikant daugiarodiklius sprendimų prièmimo metodus gauti rodiklių svorių skaitiniai ịverčiai, kurie leido sudaryti miesto seniūnijų prioritetinę eilę ir pagal ją pasiūlyti unikalią apleistų teritorijų paskirties keitimo sistemą.

3. Sudaryti trys originalūs apleistų teritorijų paskirties keitimo scenarijų igyvendinimo koncepciniai modeliai gali būti taikomi bet kokio miesto atveju. 


\section{Darbo rezultatų praktinè reikšmè}

Disertacijoje pateikta apleistas teritorijas apibūdinanti rodikliu sistema gali būti taikoma miesto kompleksinio planavimo etape rengiant strateginius ir miesto plètros planus. Šios sistemos taikymas teritorijų planavimo specialistams ir nekilnojamojo turto pletotojams sudaro tinkamas sąlygas įvertinti socialinius, urbanistinius, ekonominius ir gamtinius rodiklius. Remiantis šio vertinimo rezultatais, pasiūlytas skaičiavimo modelis, kurị taikant galima nustatyti apleistų teritorijų paskirties keitimo scenarijus ir atskirų miesto daliu plètros variantus. Sukurta ir aprašyta apleistų teritorijų vertinimo rodiklių sistema tinkama taikyti didžiuosiuose Lietuvos ir kitų Europos šalių miestuose.

Algoritmo veikimo principas grịstas daugiarodiklių metodų kombinuotu taikymu. Skirtingų daugiarodiklių sprendimų prièmimo metodų taikymas vienu metu atlikti tą pačią užduotį ir agreguotas rezultatų vertinimas yra unikalus Lietuvos ir užsienio teritorijų planavimo ir statybos mokslinès literatūros diskurse. Lietuvos teritorijų planavimo patirtis rodo, kad toks būdas leis efektyviau ịvertinti esamus apleistų teritorijų keliamus pavojus ir rasti tinkamiausius paskirties keitimo parametrus ir tinkamą jos scenarijų sutvarkant šias miesto erdves.

Pagal darbe pasiūlytą unikalią metodiką ịvertinta kiekvieno rodiklio svarba ir koreliacinis ryšys tarp miesto teritorinių bendruomenių aplinkos savybių ir apleistų teritorijų sklaidos jose. Apleistų teritorijų paskirties keitimo scenarijai nustatyti pagal mieste dominuojančių teritorijų funkcinių zonų užimamus plotus. Buvo detalizuoti šeši principiniai apleistų teritorijų paskirties keitimo taikymo scenarijai Vilniaus miesto atveju.

\section{Ginamieji teiginiai}

1. Mieste esančios apleistos teritorijos yra pasiskirsčiusios grupėmis pagal urbanizuotų zonų geografines ribas, todèl apleistų teritorijų paskirties keitimo modeliavimą galima atlikti sistemiškai sujungus miesto duomenis pagal teritorinius vienetus.

2. Apleistų teritorijų paskirties keitimo scenarijai gali būti parenkami remiantis unikaliais nagrinejjamos vietovès požymiais. Jie apibūdinami rodikliais, kurie nustatomi kaip svarbiausi kiekviename scenarijuje.

3. Dèl apleistų teritorijų sąvokos neapibrèžtumo ir skirtingų nustatymo būdų mieste esančių apleistų teritorijų skaičius yra didesnis, negu pateikiama oficialiuose planavimo dokumentuose. 


\section{Darbo rezultatų aprobavimas}

Disertacijos tema publikuoti septyni moksliniai straipsniai. Trys - mokslo žurnaluose, itrauktuose i Thomson Reuters Web of Knowledge (Clarivate Analytics Web of Science) sąrašą (Burinskienè et al. 2015, 2017; Bielinskas et al. 2018). Šie straipsniai paskelbti mokslo žurnaluose, turinčiuose citavimo rodiklį. $\mathrm{Du}$ - kitų tarptautinių duomenų bazių leidinyje (Bielinskas, Burinskienè 2015; Bielinskas, Burinskienè 2016), vienas - konferencijos ISI Proceedings straipsnių rinkinyje (Bielinskas et al. 2015), vienas - recenzuojamoje tarptautiniu konferencijų leidinyje (Bielinskas 2017).

Rengiant disertaciją, atliktų tyrimų rezultatai buvo paskelbti keturiose mokslinèse konferencijose Lietuvoje ir užsienyje:

- 18-ojoje Lietuvos jaunujų mokslininkų konferencijoje „K. Šešelgio skaitymai“ 2015 m. Rokiškyje (Bielinskas, Burinskienė 2015);

- 19-ojoje Lietuvos jaunujų mokslininkų konferencijoje „K. Šešelgio skaitymai“ $2016 \mathrm{~m}$. Vilniuje (Bielinskas, Burinskienè 2016);

- 15-oje tarptautineje konferencijoje „15th German-Lithuanian-Polish colloquium (ORSDCE 2015)“ 2015 m. Poznanèje, Lenkijoje (Bielinskas et al. 2015);

- 10-ojoje tarptautineje konferencijoje „Environmental engineering“ 2017 m. Vilniuje (Bielinskas 2017).

\section{Disertacijos struktūra}

Disertaciją sudaro 3 skyriai, bendrosios išvados, literatūros sąrašas, autoriaus mokslinių publikacijų disertacijos tema sąrašas.

Darbo apimtis - 149 puslapiai (neskaitant priedų), tekste panaudotos 41 numeruotos formulès, 27 lentelès ir 50 paveikslų. Rašant disertaciją, buvo panaudoti 199 mokslinès literatūros šaltiniai. 


\section{1}

\section{Apleistų teritorijų paskirties keitimo sampratos apžvalga}

Skyriuje pateikiama AT problematikos kilmė ir atsiradimo priežastys. Apžvelgiamos užsienio mokslinèje literatūroje vartojamos AT apibrěžtys, nagrinèjami jų tarpusavio skirtumai. Apžvelgta užsienio šalyse taikyta geroji patirtis, igyvendinti projektai. Atlikta ES ir kitų šalių norminių dokumentų, reglamentuojančių AT sprendimo būdus ir vertinimą, analizè.

Skyriaus tematika kartu su bendraautoriais paskelbti du autoriaus straipsniai (Bielinskas, Burinskienè 2015; Bielinskas et al. 2015).

\subsection{Apleistų teritorijų problemos kilmè ir jos atsiradimo priežastys}

Užsienio šalių patirtis parodè, kad socialiniai lūžiai vyksta kartu su ekonominiais. Kurortuose šie reiškiniai iš esmès lėmé turizmo sektoriaus nuosmukị ir išaugusị nedarbo lygi (Navratil et al. 2013). Dèl ekonominių veiksmų poveikio susiformavusios AT lėmé erdvinị darbo jëgos pasiskirstymo disbalansą, ypač tankiai užstatytose miesto zonose padidejo socialinė rizika (Keller 2011). Vakarų šalių 
praktika rodo, kad investuotojai ypač atkreipia dėmesị i teritorijos taršos lygi ir aplinkinių teritorijų būklę (Limasset et al. 2018; Rizzo et al. 2015).

Prasidèjus urbanizacijos procesui, dauguma pasaulio miestų susidūrè su precedento neturinčiu atveju: miestuose pradejo augti nenaudojamų teritorijų plotai nepaisant to, kad išsidèstymo aspektu šios teritorijos būdavo patraukliose miesto vietose, tačiau ekologiniu aspektu - nenaudingos ir žalingos dẻl padidejusios taršos rizikos. Dauguma nekilnojamojo turto (toliau - NT) plètros planuotojų rinkosi ekonomiškai saugesnị būdą, t. y. investuoti ì pigesnę žemę periferinèse miestų zonose, negu kurti naujos paskirties infrastruktūrą vidinėse miestų zonose.

Teritorijų pertvarkymą racionalu nagrinèti kaip socialinę, ekonominę ir teritorinę sistemą (Pueffel et al. 2018; Del Sasso, Caliandro 2010). Tokiais pačiais rodikliais AT poveikis vertinamas ir Europos Komisijos (toliau - EK) parengtoje Europos Sajungos (toliau - ES) strategijoje 2020. Joje pabrezžiama, jog žemès naudojimas ir jo perplanavimas yra svarbus procesas, siekiant kurti miestų žaliąsias dèmes (angl. greenfields), mažinti kelionių trukmę ir atstumus, gerinti bendrą gyvenimo kokybės lygị ir suteikti geresnių galimybių gyventojams viešojoje erdvejje leisti laisvalaikị arba užsiimti mažmenine prekyba komercinès ar mišrios paskirties teritorijose (Alexandrescu et al. 2018; European Commission 2010).

Dažniausiai AT atsiradimą lemia socialiniai ir ekonominiai restruktūrizacijos veiksniai, dèl kurių intensyvesnis urbanizavimo procesas vyksta didžiųjų miestų periferinèse zonose (European Commission 2013). Šiam reiškiniui itakos turèjo industrinès visuomenès transformacija i poindustrinę, privataus verslo sektoriaus reikšmès padidëjimas igyvendinant erdvinị miesto planavimą bei istoriniai šalies politikos ir kultūros lūžio taškai savitos planavimo tradicijos Europos šalyse.

Europos Komisijos AT teminiame leidinyje (European Commission 2013) apibrèžtos trys rodiklių grupès, lemiančios dykrų atsiradimą:

- Socialiniai ir ekonominiai rodikliai: populiacijos tankio, nedarbo ir turto vertès rodikliai yra ịtraukti ị šị indeksą, kuris, atsižvelgiant ị ekonomikos augimą, parodo apleistos žemės pertvarkymo potencialą.

- Pažangos augimo rodikliai: šis rodiklių grupè rodo komunalinių paslaugų ir transporto sistemos prieinamumą, užimtumo ir apgyvendinimo rodiklių reikšmes (indikatorius), kurie lemia teritorijos gyvybingumą.

- Gamtinès aplinkos rodikliai: ši rodiklių grupe apima potencialius taršos šaltinius, dirvožemio kokybès, prieinamumo prie vandens telkinių ir parkų, taip pat potvynių užliejamos teritorijos reikšmes.

Prieškriziniu laikotarpiu, kuris prasidèjo 2005 m., atsigavus statybų sektoriui, Lietuvos miestuose statybos darbų apimtis padidèjo dešimtis kartų. 1995-1996 m. pakeistos Vilniaus miesto administracinès ribos. Teritorijos plotas padidejo nuo $284 \mathrm{~km}^{2}$ iki $392 \mathrm{~km}^{2}$. Dabar bendrasis miesto plotas apytikriai lygus $401 \mathrm{~km}^{2}$. Šiu transformacijų metu daugiausia buvo planuojamos gyvenamujų daugiabučiu namų ir komercinių pastatų teritorijos (Norvilaitė 2005). Šis procesas urbanistinei 
aplinkai didžiausią pėdsaką paliko didžiuosiuose Lietuvos miestuose: Vilniuje, Kaune, Klaipedoje ir kt.

Didžiausio statybos aktyvumo periodo metais Vilniaus miesto urbanistinè struktūra patyrè didelių urbanistinių ir socialinių deformacijų. Dėl pasikeitusio ekonominio klimato ir visuomenès raidos pokyčių reikšminga miestiečių dalis persikèlè gyventi i priemiesčius. Šiose miesto dalyse nevaldomomis miesto planavimo sąlygomis susiformavo nauji gyvenamieji rajonai (1.1 pav.), vyko esamų teritorijų funkcijų transformacijos.
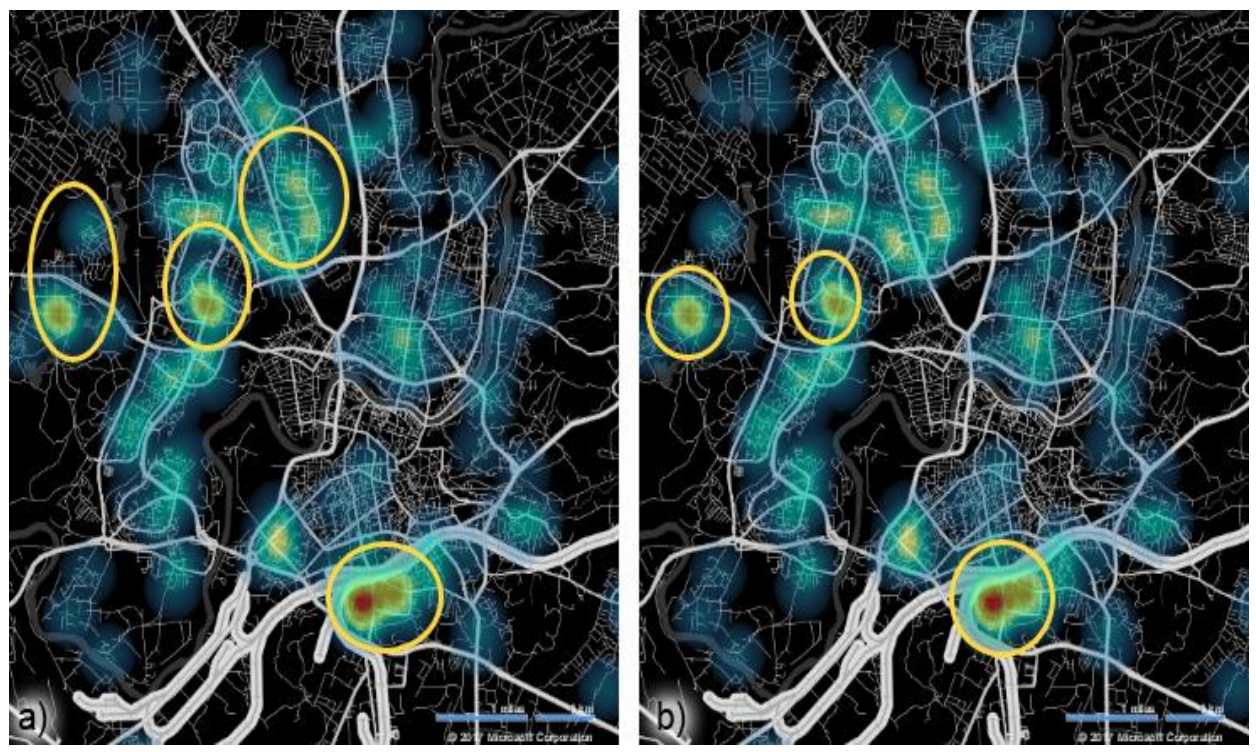

1.1 pav. Būstų erdvinis pasiskirstymas Vilniuje išryškinant: a) naujos statybos būstus; b) mažiausios vertès būstus (sudaryta autoriaus)

Fig. 1.1. The spatial distribution of residential real estate objects in Vilnius by highlighting: a) new built properites; b) properties of the lowest prices (created by author)

Pateikti pavydžiai rodo, kad nauji gyvenamieji būstai planuojami periferinèse ir mažesnès vertès miesto teritorijose. Pastebima, kad šiose miesto dalyse vis dažniau nesilaikoma statybos ir teritorijų planavimo norminių reikalavimų.

Dèl sunkiai valdomo statybos darbų proceso ir kontroliavimo miestų urbanistinis karkasas tapo išdarkytu ir neatitinkančiu šiandienių gyvenimo kokybės veiksnių, ypač pasiekiamumo ir socialinio aprūpinimo. Tai iliustruoja reiškinys, kai miesto BP nurodoma pramoninès paskirties teritorija iš tiesų yra jau daugelị metų nenaudojama ir žalinga miestui, o ypač tos teritorijos gretimybėms (Martinat et al. 2016). Išliekant tokiai teritorijų planavimo politikai, AT pavojai 
ne tik nèra sprendžiami, tačiau jie stiprèja, ypač ekologiniu aspektu. Dažnai tai yra priežastis, kodėl NT plètotojai vietoj tokių teritorijų pertvarkymo renkasi gretimas teritorijas, kuriose, nors naujos statybos potencialas apytikriai vienodas, pertvarkymo darbai (grunto valymas, ịvaizdžio kūrimas, esamos infrastruktūros atnaujinimas ir kt.) yra minimalūs.

Tokiomis sąlygomis kilo pavojus Vilniaus miesto žaliajam žiedui, jose esančioms žemės ūkio naudomenoms (toliau - ŽŪN). Dèl šių deformacinių pokyčių vidinès miesto teritorijos pradejo tuštèti ir neatlikti savo pirminès funkcijos, todèl šios ir aplinkinès tapo nepatrauklios investuoti, o regeneracijos projektai rengiami tik atskirais atvejais. Tokiomis sąlygomis šios teritorijos tampa apleistos ir jų neigiamas poveikis miestui auga proporcingai išorinio ịsitraukimo delsos laikui.

JAV mokslininkai (Newman et al. 2018) ir Pakalnis (2014) pažymi, kad didelę ịtaką miesto dykrų atsiradimui daro gyventojų demografiniai pokyčiai (1.2 pav.). Sociodemografiniai pokyčiai miestuose sudaro palankias sąlygas socialinių ryšių gyventojų bendruomenèse nykimui. Tai iš esmès komplikuoja miesto planavimo ir atskirų teritorijų sutvarkymo problemų sprendimą. Tai ekonominei, gamtinei, urbanistinei ir socialinei aplinkai darantys įtaką veiksniai. Dažnu atveju šių veiksnių rezultatas ilgalaikejje perspektyvoje yra didejjantys nenaudojamų žemių plotai (kadaise tikslingai funkcionavusių žemių degradacija). Šiomis sąlygomis apleistų teritorijų sutvarkymas turi būti laikomas prioritetiniu sprendžiant strategini miesto planavimą. Tokių teritorijų pertvarkymo ar atnaujinimo klausimai keliami tik atskirais atvejais, paprastai pasiekus kritinę nepasitenkinimo esama situacija ribą.

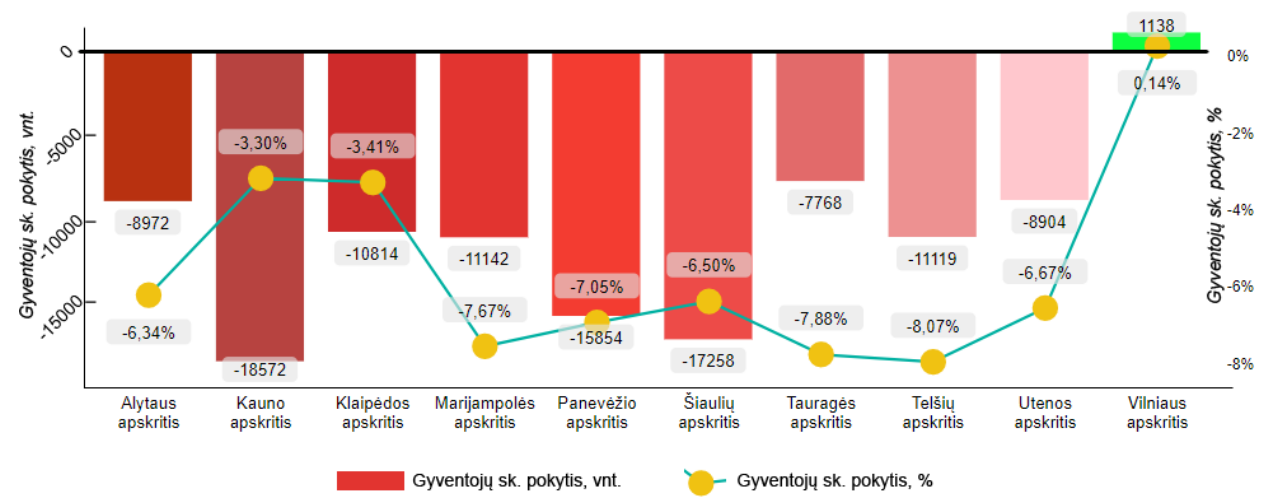

1.2 pav. Gyventojų skaičiaus pokyčiai Lietuvos apskrityse (2013-2018 m.) (sudaryta autoriaus pagal Lietuvos statistikos departamento (2018) duomenis)

Fig. 1.2. Residential differences in Lithuanian regions for the period 2013-2018 (created by author based on data of Department of Lihuania statistics 2018) 
Statistika rodo, kad per pastaruosius šešerius metus didžiausiose Lietuvos apskrityse gyventojų akivaizdžiai sumažèjo. Didžioji dalis dèl labiau gyventojų poreikius atitinkančių sąlygų išvyko gyventi ị Vilnių (vienintelè apskritis, kuri patyre teigiamų demografinių transformacijų). Viena iš šio reiškinio pasekmių yra didesnis miesto teritoriju poreikis planuoti naujus gyvenamuosius rajonus ar lokalias gyvenamąsias zonas. Ši uždavinị galima spręsti tikslingai naudojant mieste (arba greta jo) esančias AT.

\subsection{Apleistụ teritorijų tipologija ir apibrèžtys skirtingose šalyse}

Mokslinèje literatūroje AT apibrèžtis dažnai minima kartu su urbanistinių ruduju demiu terminu (Loures, Vaz 2018; Navratil et al. 2018; Mathey et al. 2018). Disertacijos problemai nagrinèti ir naudojamas AT terminas. Mokslinejje literatūroje AT paskirties keitimas apibūdinamas terminu konversija. Išvertus iš lotynų kalbos jis reiškia pakitima. Atsižvelgus ị mokslinejje literatūroje (Koch et al. 2018) pateiktus pavyzdžius, disertacijoje AT paskirties keitimas vertinamas kaip žemès ploto pertvarka su visa jame esančia inžinerine infrastruktūra, antžeminiais ir požeminiais statiniais, prieigomis, socialine ir gamtine aplinka.

AT sąvokos pagal taikomą požiūrị ir nagrinėjamą problemą yra dažnai skirtingos. Kiekviena iš jų turi savo privalumų ir trūkumų (1.1 lentelè).

1.1 lentelè. Apleistų teritorijų sąvokų palyginimas pagal taikomą požiūrį (Pointereau et al. 2008)

Table 1.1. The comparison of the applied definitions for brownfields considering different approaches (Pointereau et al. 2008)

\begin{tabular}{|c|c|c|c|}
\hline Požiūriai & Sąvoka & Privalumai & Trūkumai \\
\hline 1 & 2 & 3 & 4 \\
\hline \multirow[t]{2}{*}{ Administracinis } & $\begin{array}{l}\text { ŽŪN apleistos, jeigu } \\
\text { be priežiūros ilgiau } \\
\text { nei } 5 \text { metus }\end{array}$ & \multirow[t]{2}{*}{ Sąvoka aiški. } & \multirow{2}{*}{$\begin{array}{l}\text { Tik žemès ūkio } \\
\text { paskirties ūkininkų } \\
\text { deklaruojama žemė. } \\
\text { Neatsižvelgiama ì } \\
\text { žemes, valdomas } \\
\text { kelių ūkių. }\end{array}$} \\
\hline & $\begin{array}{l}\text { Žemé, kuri } \\
\text { nenaudojama } \\
\text { gamybai } 2 \text { metus }\end{array}$ & & \\
\hline Ekonominis & $\begin{array}{l}\text { Žemė laikoma ap- } \\
\text { leista, kai ji nebe- } \\
\text { naudojama kaip eko- } \\
\text { nominis išteklius. }\end{array}$ & $\begin{array}{l}\text { Gali būti fiksuo- } \\
\text { jama AT verte, } \\
\text { lyginant su vidu- } \\
\text { tine žemès kaina. }\end{array}$ & $\begin{array}{l}\text { Žemé turi ne tik } \\
\text { ekonominę funkciją. }\end{array}$ \\
\hline
\end{tabular}


1.1 lentelès pabaiga

\begin{tabular}{|c|l|l|l|}
\hline 1 & \multicolumn{1}{|c|}{2} & \multicolumn{1}{c|}{3} & \multicolumn{1}{c|}{4} \\
\hline Kraštovaizdžio & $\begin{array}{l}\text { Žemė, kurioje } \\
\text { augalinės dangos - } \\
\text { krūmų ir medžių - } \\
\text { dalis viršija normas. }\end{array}$ & $\begin{array}{l}\text { Paprasta apskai- } \\
\text { čiuoti, taikant paly- } \\
\text { dovini fotografavi- } \\
\text { mą arba topografa- } \\
\text { vimą. }\end{array}$ & $\begin{array}{l}\text { Ta pati augalija gali } \\
\text { augti esant skirtingai } \\
\text { žemès naudojimo } \\
\text { paskirčiai. }\end{array}$ \\
\hline Agronominis & $\begin{array}{l}\text { Žemė, kurioje } \\
\text { ūkininkaujama } \\
\text { ekstensyviai. }\end{array}$ & $\begin{array}{l}\text { Yra daug skirtingų } \\
\text { žemės naudojimo } \\
\text { būdų, kuriuos sunku } \\
\text { diferencijuoti. }\end{array}$ \\
\hline
\end{tabular}

Iki šiol nèra bendro AT apibrèžimo ir jokio bendro susitarimo, kaip reikètų traktuoti apleistas, nefunkcionalias ir paskirties keitimui tinkamas teritorijas ES šalyse. Europos ekspertų tinklas CABERNET komentuoja, kad apleista teritorija turètų būti laikoma išvystyta arba apleista žemė, kuri apima aibę dydžio ir išsidèstymo miesto kontekste veiksnius (European Commission 2010). Nustatant tiriamają problemą, visų pirma reikia apibrèžti apleistas teritorijas kaip pagrindinị tyrimų objektą. Europos ekspertų tinklas rekomenduoja atlikti AT atpažinimą pagal šiuos bruožus:

- buvo paveiktos aplinkinių teritorijų arba anksčiau vykdytos veiklos;

- yra apleista ir nenaudojama;

- yra iš dalies arba visiškai išvystytoje miesto teritorijoje;

- reikalauja suinteresuotų šalių ịsikišimo, kad teritorijos funkcionavimas būtų atkurtas arba iš naujo sukurtas;

- gali turèti faktines arba tariamas ekologines problemas (European Commision 2010).

Šios formuluotès gali būti lyginamos kartu su Didžiojoje Britanijoje naudojamu ankstesniojo naudojimo žemes apibréžimu (Popescu, Patrascoiu 2012). Daugelio ES šalių AT tvarkymo praktika rodo, kad didžioji dalis šių teritorijų yra pramonines paskirties, t. y. jose pastatyti seni nebenaudojami pramoniniai ar inžineriniai pastatai ir priestatai. Tai ypač būdinga anksčiau Sovietų Sajungos valdytoms šalims (Lietuvai, Čekijos Respublikai, Slovakijai ir kt.).

Lietuvos planavimo normose (2014) teritorijų paskirties keitimas apibrežiamas kaip neefektyviai naudojamų užstatytų pramoninių teritorijų (miestų centruose ir jų prieigose esančios padidejjusios taršos ar neefektyvios teritorijos) antrinis naudojimas plètrai vykdyti. Leitanaite (2007) paskirties keitimo terminą apibrežia kaip būdą pertvarkyti nebeaktualios paskirties miesto teritorijų struktūras ir pritaikyti joms naujas funkcijas:

- pramoninès;

- karinès; 
- susisiekimo sistemos;

- žemès ūkio paskirties;

- komercinès;

- kultūrinès;

- laisvalaikio paskirties (sporto aikštynai, parkai);

- institucinès (mokyklos, ligoninès, kalejjimai);

- uostai, upių baseinai ir pan.;

- kitos.

Daugelis autorių (Martinat et al. 2018, Theobald 2014; Popescu, Patrascoiu 2012; Ling 2008) AT nustato ir apibūdina skirtingai, atsižvelgdami ị nagrinèjamą tyrimų tikslą ir pasirinktus nagrinèti objektus. Mokslinèje literatūroje ir politinèse gairèse pastebèta dar didesnių skirtumų suklasifikavus AT apibrèžimus pagal šalis ir jų grupes (1.3 pav.).

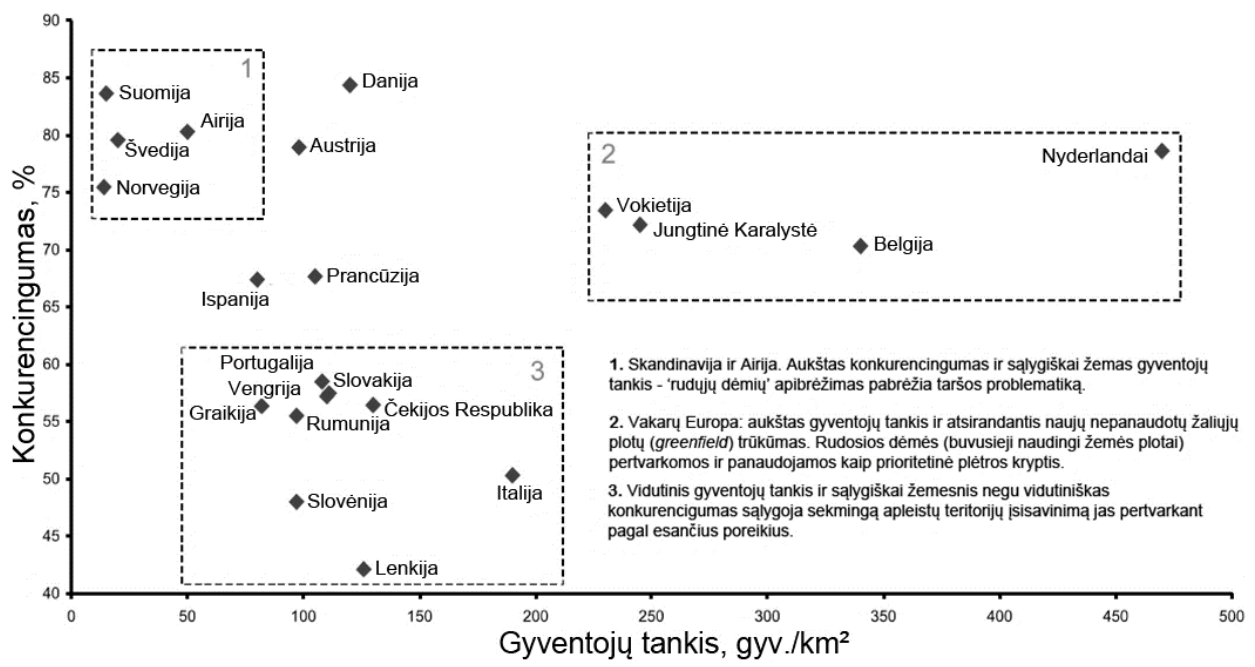

1.3 pav. Apleistų teritorijų apibendrintų apibūdinimų palyginimas skirtingose Europos Sajungos šalyse, įvertinant konkurencingumo lygị ir gyventojų skaičiaus rodikli (Popescu, Patrascoiu 2012)

Fig 1.3. The comparison of the generalized definitions of urban brownfields in different European countries evaluating the level of competetiveness and the population criterion (Popescu, Patrascoiu 2012)

Dažnai apleistos teritorijos mokslinëje literatūroje ịvardijamos ruduju dèmiu (angl. urban brownfield) terminu. Pirmą kartą šị terminas buvo pavartota $1992 \mathrm{~m}$. Jungtinèse Amerikos Valstijose (toliau-JAV). Apibendrintas rudujų dėmių apibrěžimas kilo iš Aplinkos apsaugos agentūros (JAV) 1997 m. Apbrèžimas 
skambejo taip: „Apleistos, neišnaudotos komercinès ir pramoninès paskirties patalpos, kur plètra ar pertvarkymas yra komplikuotas dèl faktinio arba galimo aplinkos užterštumo“ (US. EPA 2003). Šis apibrèžimas buvo pakoreguotas $2002 \mathrm{~m}$. (Ling 2008). Apibrèžimo sampratai ịtakos turëjo Kanadoje ir Kinijoje nusistovèjęs skirtingas požiūris ị AT keliamas problemas. Šie skirtumai išryškino tokių teritorijų ekonominị potencialą. Atsižvelgus ị pasiūlytas korektūras, apleistas teritorijas galima apibrèžti šitaip: „Anksčiau naudotos, tačiau dèl faktinio ar galimo aplinkos užterštumo dabar nebenaudojamos, bet turinčios ekonomini potencialą ir galinčios pagerinti socialinę aplinką suteikiant naują funkcinę būseną, teritorijos." Vadovaujantis šiuo AT apibrěžimu, disertacijoje atlikti toliau pateikti tyrimai ir parengtos rekomendacijos.

Trumpos įvairių Europos šalių apibrèžimų analizès rezultatai atskleidžia, kad daugumoje šių šalių AT suprantamos kaip apleisti pramoninès paskirties sklypai (Rumunija, Bulgarija) arba kaip apleistos žemès, kurios turi faktinių arba galimų taršos problemų. Detalesnis AT užsienio literatūroje randamų apibrěžimų sąrašas pateiktas 1.2 lentelèje (CABERNET 2007).

Nepaisant didelio skaičiaus apžvalginių mokslinių straipsnių ir vietinių studijų, dabartinèje mokslinèje literatūroje pasigendama bendrosios, vientisos rudujų dėmių problematiką apibrèžiančių rodiklių metodologijos. Iki šiol AT apibrezžimas buvo siejamas daugiausia su užterštos žemės plotu, šis požiūris išliko iki šių dienų (Loures, Vaz 2018; De Vivo, Lima 2018).

Atsižvelgus $\mathfrak{i}$ anksčiau pateiktus argumentus apie AT apibrèžimus ir remiantis mokslinèje literatūroje pateiktomis rekomendacijomis AT vertinti pagal ekonomini lygi (CABERNET 2007; Donaldson, Lord 2018), disertacijoje tokios teritorijos apibūdinamos kaip savaime atsinaujinančias, ekonomiškai patrauklias ir tinkamas miesto rezervui (geografiniais, technologiniais ir kitais veiksniais, neatitinkančiais esamų miesto prioritetų). Esminè ir užsienio moksline literatūra grindžiama AT apibrěžimų klasifikacijos schema pateikta 1.3 paveiksle. Remiantis ja ir užsienio šalių patirtimi, mažiausiai kaštų regeneracijos procesams reikalauja savaime atsinaujinančios AT. Tai yra mažiausias ir rečiausiai aptinkamas visų AT imties poaibis. Tokio pobūdžio AT atgauna savo estetinị vaizdą ir funkcionalumą pagal konkrečius gyventojų ar verslo poreikius.

Daugiausia demesio Lietuvoje ir užsienio šalyse skiriama ekonomiškai patrauklioms AT. Darbe pateiktuose tyrimuose šios teritorijos užima du trečdalius visų AT. Ekonomiškai stiprioms AT būdinga daugiausia galimų naudojimo scenarijų, palyginti su likusiomis. Šios teritorijos yra susitelkusios ekonomiškai patraukliausiose miesto vietose (centrineje miesto dalyje, gyvenamųjų rajonų susibūrimo vietose, jų prieigose ir kt.), tad miestų savivaldos sistemai jas atkurti ar atlikti paskirties keitimą, parenkant geriausius scenarijus, dažnai tampa finansiškai sunkiu uždaviniu. Vis dažniau pasitelkiamas PPP ekonominis modelis (angl. Public and Private Partnership). 
1.2 lentelė. Apleistų teritorijų apibrėžčių Europos šalyse palyginimas (sudaryta autoriaus) Table 1.2. The comparison of the definitions of urban brownfields in different European countries (created by author)

\begin{tabular}{|c|c|}
\hline Šalis & Apibrëžimas \\
\hline Austrija & $\begin{array}{l}\text { Oficialaus apibrèžimo nėra. Neoficialus supratimas panašus ị } \\
\text { CABERNET priimtą apibrèžimą, apibūdinantị potencialias antriniam } \\
\text { naudojimui skirtas teritorijas, mažiau atkreipiant dėmesi ị taršos } \\
\text { pavojų. }\end{array}$ \\
\hline $\begin{array}{l}\text { Belgija } \\
\text { (Valonija) }\end{array}$ & $\begin{array}{l}\text { Sklypai, kurie anksčiau buvo skirti ekonominei paskirčiai, tačiau } \\
\text { dabar panaudojimas yra įvardijamas kaip ,priešingas efektyviam } \\
\text { žemès naudojimui“. }\end{array}$ \\
\hline $\begin{array}{l}\text { Belgija } \\
\text { (Flandrija) }\end{array}$ & $\begin{array}{l}\text { Apleistos ir anksčiau naudotos teritorijos, tačiau iki šiol turinčios } \\
\text { aktyvų potencialą būti pertvarkytos arba išplèstos, tačiau šias } \\
\text { galimybes riboja reali arba galima / reali (faktinės) taršos pavojų. }\end{array}$ \\
\hline Bulgarija & $\begin{array}{l}\text { Užterštos teritorijos - teritorijos, kuriose ankstesnè veikla yra } \\
\text { nutraukta, tačiau tokios veiklos įtaka vis dar jaučiama gretimybėms. }\end{array}$ \\
\hline Prancūzija & $\begin{array}{l}\text { Anksčiau plètota, tačiau dabar atvira erdvè, kuri šiuo metu laikinai } \\
\text { arba visiškai aktyviai nenaudojama, tačiau būtina atkurti ateities } \\
\text { reikmėms. }\end{array}$ \\
\hline Nyderlandai & $\begin{array}{l}\text { Teritorijos miestuose ir miesteliuose, kuriose buvo vykdoma pramonine } \\
\text { veikla, tačiau šiuo metu ji nutraukta, o teritorija nenaudojama. }\end{array}$ \\
\hline Rumunija & Užteršta žemė (dirvožemis, gruntai). \\
\hline Slovėnija & $\begin{array}{l}\text { Visiškai nebefunkcionali apleistų pastatų žemė, paprastai aptinkama } \\
\text { miesto urbanizuotose teritorijose. }\end{array}$ \\
\hline $\begin{array}{l}\text { Ispanija (tik } \\
\text { Baskų } \\
\text { kraštas) }\end{array}$ & Potencialiai užterštos žemės plotai. Pramoninių pastatų griuvėsiai. \\
\hline $\begin{array}{l}\text { Anglija ir } \\
\text { Velsas }\end{array}$ & $\begin{array}{l}\text { Anksčiau plètota žemè - žemės plotas, kuris dabar arba anksčiau yra } \\
\text { nuolatinės užstatymo struktūros (išskyrus žemės ūkio ar miškų ūkio } \\
\text { priestatus ir pastatus), kuri turi jungtis su fiksuota paviršiaus } \\
\text { infrastruktūra. }\end{array}$ \\
\hline
\end{tabular}

Tolesni geostatistinès AT analizès Vilniaus mieste rezultatai parodè, kad AT, pagal BP patenkančios i miesto rezervui skirtas zonas, paplitusios pramoninès paskirties teritorijų prieigose, miesto pakraščiuose. Kadangi šio tipo AT regeneracijos kaštai dèl gamtinių ir vietovès savybių mažai patraukliose miesto vietose yra didžiausi, o verslo subjektams esamuoju laiku investuoti ị šių AT atgaivinimą yra neefektyvu ir nenaudinga, savivaldos sistemai ją eksploatuoti yra pernelyg finansiškai sunku, racionalu šias teritorijas palikti kaip neišnaudotą 
miesto išteklių ateities investicijoms, kai miesto plètros strategija lems efektyvesni šių teritorijų naudojimą. CABERNET išskyrė AT grupes pagal jų naujo naudojimo tikimybę (1.4 pav.).

Savaime besivystančių sklypų tipui priskiriamoms AT, kuriose nebūtina valstybės ekonominè intervencija. Jas tvarko privačių investuotojų rinka. Tačiau joms vis tiek gali būti reikalinga ,švelnus“ valstybès įsitraukimas - formalioji (planavimas) arba neformalioji (neformali pagalba sujungiant sklypą, pagreitinant leidimų išdavimą ir pan.). Potencialiai ekonomiškai stiprių sklypų tipui geriausia valstybès ịsitraukimo strategija - padèti jų savininkams (formaliai, neformaliai arba, pavyzdžiui, planuojant, arba skiriant atskiras valstybės investicijas tokiems tikslams kaip susisiekimo pagerinimas, aprūpinimas arba autobusų stotelių irengimas ir pan.) paversti šiuos sklypus savaime besivystančiais sklypais. Šitaip sumažinami jų poreikiai valstybès ekonominei intervencijai, kuri būtų buvusi reikalinga kitu atveju; rezervinių sklypų išvalymas ir sutvarkymas priklauso tik nuo valstybès ekonominès intervencijos. Šiuo atveju tinkamiausia strategija padaryti juos B tipo sklypais. Sklypai, keliantys galimą pavojų visuomenei, stipriai sudarko vietovaizdi arba yra laikomi istorine vertybe, turi būti išvalomi ir sutvarkomi. Kitų sklypų likimas priklausys nuo jų poreikio rinkoje būtinumo ịvertinimo arba bus natūraliai veikiami ir naikinami gamtos (CABERNET 2007).

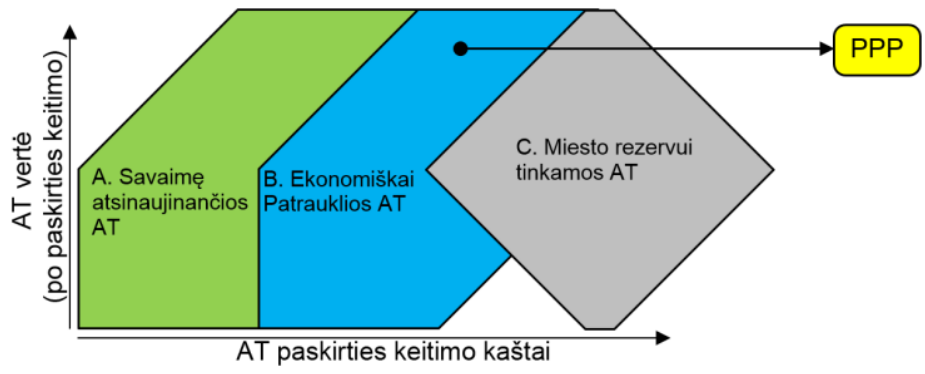

1.4 pav. Apleistų teritorijų klasifikacija pagal potencialią ekonomikos vertę ir paskirčiai keisti būtinus kaštus (Petríková et al. 2012)

Fig. 1.4. The classification of brownfields considering the potential value of economy and costs estimated for changes in land purpose (Petríková et al. 2012)

Atsižvelgus ị užsienio šalių praktikoje taikomas AT apibrèžtis, Lietuvos miestuose AT keliamus pavojus ir mokslinèje literatūroje nagrinejjamas AT savybes, galima teigti, kad anksčiau plètotose ir dabar nenaudojamose bent vienerius metus apleistose teritorijose (nebūtinai užterštose) esantys pastatai ir statiniai (jeigu jų yra) arba jų liekanos neatitinka minimalių reikalavimų juos eksploatuoti nagrinèjamu momentu. 
Siekiant objektyviai įvertinti skaitmenintas AT, pagal surinktus duomenis, jų poveikio tipą ir apimtis sudaryta $\mathrm{DB}$, kurioje duomenys geografiškai agreguoti seniūnijos lygmeniu ir išvesti ankstyvieji vertinimo rodikliai (3.1.2 poskyris).

\subsection{Apleistų teritorijų klasterizacija taikant kompiuterinio mokymosi metodą}

Siekiant nustatyti AT grupes geografiniame modelyje, atlikta jų klasterizacija taikant Vilniaus miesto skaitmenizuotą modelį. Klasterizacija atlikta nagrinejjant atstumą nuo miesto centro (miesto centrą kaip atskaitos tašką laikant Vilniaus miesto centrini paštą) ir tenkanti gyventojų skaičiu $400 \mathrm{~m}$ aplink jas esančioje buferinejje zonoje, pritaikius mašininio mokymosi (angl. Machine learning, toliau - ML) metodiką ir hierarchinio klasterizavimo (angl. Hierarchical clustering, toliau - HL) būdą (1.5 pav.).
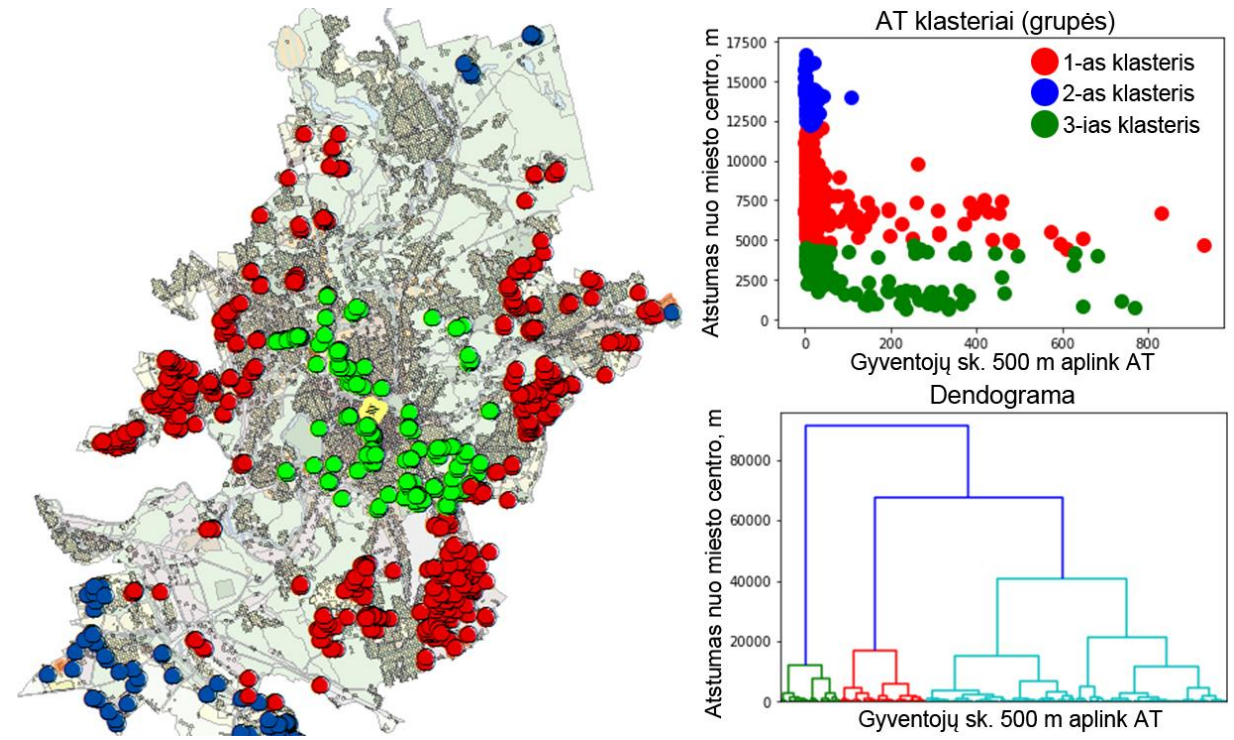

1.5 pav. Apleistų teritorijų klasteriai, suskirstyti pagal gyventojų skaičių $400 \mathrm{~m}$ buferineje zonoje ir atstumą iki miesto centro $2016 \mathrm{~m}$. (sudaryta autoriaus)

Fig. 1.5. The defined clusters of brownfields divided according to the number of residents in the buffer zone of $400 \mathrm{~m}$ and the distance from the city center in 2016 (created by author)

Nors Lietuvoje ML technologija statybos ir teritorijų planavimo srityse iki šiol nebuvo taikyta, pasaulyje, įskaitant ir neuronų tinklų veikimu grịstus 
metodus, tai gan plačiai paplitęs metodas analizuoti statybos objektus, teritorijas, atlikti jų prognozes ir segmentaciją (Chen et al. 2018; Duerr et al. 2018; Pourghasemi, Rahmati 2018). Pritaikius ML ir HL klasterizacijos būdą bei panaudojus AT duomenis Vilniaus mieste, gauti trys geografiniai klasteriai. Jie tarpusavyje sudaro tris demografiniu požiūriu skirtingas miesto zonas, kurias perdengus su Vilniaus miesto centrine, tankiausiai apgyvendinta ir periferine zona, gaunamos vienodos ribos:

- 0-800 gyventojų, atstumas iki miesto centro 0-4,9 km (1-asis tipas);

- 0-650 gyventoju, atstumas iki miesto centro 4,9-12 km (2-asis tipas);

- 0-60 gyventoju, atstumas iki miesto centro 12-17 km (3-iasis tipas).

Taikant ML metodiką, AT galima klasterizuoti pagal bet kokiais kiekybiniais ir kokybiniais veiksniais aprašomus objektus (Eremenko 2018).

HL rezultatai parodè, kad ekonomiškai patraukliausios teritorijos apima didžiąą dali 2-ojo tipo teritorijų, susitelkusių aplink miesto centrą, pasižyminčių geru pasiekiamumu viešuoju ir privačiu transportu šalia jau išvystytų miesto teritorijų ir mažesnè NT verte. Šio tipo AT apima $39 \%$ visų AT ir apima didžiausią gyventojų dalị, susikoncentravusią AT prieinamumo zonose.

Šie duomenys leidžia nustatyti prioritetines miesto zonas, sprendžiant optimalaus AT antrinio naudojimo problemą. Didinant ML ir HL klasterių skaičių, gaunami tikslesni rezultatai: pereinama iš $\mathrm{BP}$ ị vietovès lygmenị. Skirstant Vilniaus miesto seniūnijas $\left(D_{i}\right)$ pagal svarbą, tai suteikè papildomų duomenų spręsti AT naudojimo uždavinius (2.3 poskyris).

Hierarchinès klasterizacijos algoritmą vykdantis kodas, parengtas Python programavimo kalba, pateiktas A priede.

\subsection{Apleistụ teritoriju vertinimo principai. Paskirties keitimo tipai}

Tarptautinis požiūris ị AT problemų sprendimo būdus brendo daugiau kaip 40 metų - nuo 1970 m., kai AT naudojimo klausimas buvo įkeltas tarp prioritetinių sprendžiant statybos ir urbanistinio pobūdžio problemas. Dabar šie būdai yra stipriai susieti su darnaus miestų bei regionų plètros gairèmis ir turi būti taikomi pagal šiandien galiojančias normas ir pakitusią urbanistinę aplinką.

Skirtingos pasaulio šalys turi nevienodus standartus ir normas, pagal kuriuos vertinamos teritorijos kartu su visa urbanizuota ir neurbanizuota aplinka. Tai reiškia, kad riba, kurią viršijus, teritorija tampa dykra, yra reliatyvi sąvoka. Ją teritorijos regeneracijos atžvilgiu reikètų vertinti atsižvelgiant ị konkrečios šalies arba teritorijos mikroklimatą, būdingą urbanistinę struktūrą, užterštumo lygị, vyraujančią gyventojų socialinę padèti ir kitus veiksnius (United States Environmental... 2011). 
Mokslinèje literatūroje išskiriami trys AT paskirties keitimo poveikio tipai: ekonominis, socialinis ir aplinkos. Pagal teritorijos rūši apibendrinti šių tipų poveikio galimi rezultatai pateikti 1.3 lenteleje.

Priskyrus teritoriją kaip AT, turi būti numatomi šie veiksmai siekiant subalansuoti miesto plètrą pertvarkant jo teritorijas pagal darnios plètros principus:

- galutinès žemès paskirties parinkimas;

- paskirties keitimo procedūros parinkimas (kokiu būdu turi būti pakeista teritorijos paskirtis);

- tolesnio teritorijos naudojimo vizija, jos parinkimas, integravimo ị bendrą urbanistinį karkasą strategija.

Atsižvelgiant ị mokslinèje literatūroje aptinkamus pavyzdžius (Paul Bardos et al. 2016; Krejčí et al. 2016), pramoninès paskirties objektų ir AT paskirties keitimas gali vykti keliais būdais:

- kai paskirtis atnaujinama;

- kai paskirtis keičiama išsaugant nepakitusią architektūrinę-urbanistinę išraišką. Tinka tuo atveju, kai objektas pripažintas industriniu paveldu;

- kai paskirtis keičiama iš esmès keičiant situaciją - tai kompleksinè teritorijos regeneracija. Vykdoma tais atvejais, kai pramoninès paskirties objektas yra pripažintas visiškai neveiksniu ir neatitinkančiu naujų poreikių, todèl yra rengiama nauja urbanistinè koncepcija.

AT poveikio tipo nustatymas sudaro sąlygas atpažinti galimus AT pavojus ir numatyti teritorijų planavimo priemones šiems pavojams sumažinti arba panaikinti.

1.3 lentelè. Apleistų teritorijų vertinimas pagal poveikio tipą

Table 1.3. The brownfield's assessment considering the type of effect

\begin{tabular}{|l|l|l|}
\hline $\begin{array}{l}\text { Poveikio } \\
\text { tipas }\end{array}$ & Fizinè būklè (ivertinant taršą) & \multicolumn{1}{|c|}{ Ekonominė būklė } \\
\hline $\begin{array}{l}\text { Ekonominis } \\
\text { poveikis }\end{array}$ & $\begin{array}{l}\text { Aplinkinių sklypų (gretimybès) } \\
\text { nuvertėjimas. }\end{array}$ & $\begin{array}{l}\text { Ekonominių galimybių praradimas, } \\
\text { mokesčių bazès netekimas. }\end{array}$ \\
\hline $\begin{array}{l}\text { Socialinis } \\
\text { poveikis }\end{array}$ & $\begin{array}{l}\text { Gretimų teritorijų nuvertè- } \\
\text { jimas, nepatrauklumas. }\end{array}$ & $\begin{array}{l}\text { Darbo vietų sumažèjimas, ypač cent- } \\
\text { rinėje miesto dalyje. }\end{array}$ \\
\hline $\begin{array}{l}\text { Ekologinis } \\
\text { poveikis }\end{array}$ & $\begin{array}{l}\text { Galima rizika gamtai ir žmonių } \\
\text { sveikatai, žala biologinei įvai- } \\
\text { rovei ir ekosistemos palaikymo } \\
\text { funkcijoms. }\end{array}$ & $\begin{array}{l}\text { Žemès plètros galimybių suma- } \\
\text { žjimas, aplinkai žalingos miesto } \\
\text { plètros vykdymas. }\end{array}$ \\
\hline
\end{tabular}

Mokslinėje literatūroje gausu apžvalginių mokslinių straipsnių, vietinių atvejo studijų ir gerosios patirties pavyzdžių. Nepaisant to, dabartinèje mokslinëje literatūroje pasigendama bendrosios, vientisos AT poveikị ir galimą panaudojimą 
apibrèžiančių rodiklių nustatymo metodologijos. Pasigendama kompleksiško daugiasektorinio vertinimo, kuris leistų hierarchizuoti šiuos veiksnius pagal kiekvienos šalies prioritetus, keliamus tikslus ir turimas galimybes. Šiam tikslui tinka daugiarodiklis kiekybinis rodiklių vertinimas, pasitelkiant geriausius ir didžiausią darbo patirtị turinčius specialistus.

\subsection{Apleistų teritorijų apimties ir skaičiaus mažinimo būdai. Geroji užsienio šalių praktika}

Tvaraus urbanizmo koncepcijos daugiau nei dešimtmeti yra aktualios ir analizuojamos ịvairių užsienio (Xiaoling, Huan 2018; Céspedes Restrepo, Morales-Pinzón 2018; Mostafati 2010) ir Lietuvos urbanistikos bei kraštovaizdžio specialistų (Burinskienè et al. 2003; Stauskis 2010; Urbonaitè 2010, 2011; Zaleckis et al. 2014 ir kt.).

Plataus masto miesto teritorijų atgaivinimo programos grịstos sociokultūrinèmis ir politinès strategijos idèjomis. Jos igyvendintos Barselonoje (1992), Bilbao (1997), Glazge (2000), Kardife (2004) ir kituose miestuose (Klusáček et al. 2018, Håkansson 2017). Atskirus teritorijų atgaivinimo atvejus nagrinejjo Moldoveanu ir Franc (2013). Kompleksiškai taikant bendruomenių ìsitraukimo ị planavimo procesus idejas bei iggyvendinant socialinę ir ekonominę plètrą, Didžiojoje Britanijoje susiformavo savita planavimo kultūra, kuri tapo etalonu kai kurioms kitoms Europos šalims (Hallsworth, Coca-Stefaniak 2018; Shaw et al. 2018; Butkus 2011).

Vidinis ryšys tarp ekonomikos ir aplinkos geriausiai rodo AT formavimosi dinamiką, kuriai didžiausią įtaką daro ekonominès plètros planavimas ir jị lemiantys faktoriai (Rafson, Harold J. 1999). Kai 1981 m. užsidare paskutinis Londono dokas, nedarbo lygis išaugo iki $17,8 \%$, per dešimtmeti išsikèlè per $20 \%$ gyventojų, dẻl to sumažèjo daugiau nei 10 tūkst. darbo vietų. Visas pramoninis rajonas ant Temzès pakrantès ėmè merdeti. Nors pakrančių žemių paskirtis imta keisti iš karto po dokų uždarymo, šs procesą komplikavo daug žemès savininkų. Tam, kad teritorijos pertvarkymo procesai vyktų sistemingai ir atitiktų miesto plètros strategijos nuostatas, ịsteigta nevalstybinè organizacija LDDC. Visa žemès paskirčiai numatyta teritorija užèmė maždaug 22 ha. LDDC buvo suteiktos teisès nustatyti planuojamų pastatų aukštingumo, eksterjero parametrus, igyti savininkų teisę ir kt. Taip pat priskirtos dalinès plètros ir reguliavimo teisès, o tai dare įtaką naujų investuotojų pritraukimui.

Keičiamos paskirties teritorijose įsikūrè muziejai, teatrai, bibliotekos, kitos viešosios įstaigos, pastatyti gyvenamujų namų kompleksai. Šitaip buvo sukurta daugiafunkcè miesto zona, turinti didelị kultūros, komercijos ir gyvenamojo fondo potencialą. Ryškiausias paskirties keitimo simbolis yra Canary Wharf mikrorajonas, 
kuriame buvo pastatytas didžiausias Didžiojoje Britanijoje verslo centras. Gautos lěšos buvo paskirstytos viešosioms ịstaigoms steigti, infrastruktūrai gerinti, naujiems keliams tiesti ir kt. (Matulevičius, Šliogerienè 2011).

Vieną naujausių AT galimų pavojų tyrimų - gyvavimo ciklo vertinimą (angl. Life-cycle assessment) - atliko Belgijos ir Nyderlandų mokslininkai Beames, Broekx ir kt. (Beames et al. 2018, 2015). Nepaisant to, kad tirti buvo pasirinkta tik viena 2 ha ploto teritorija Belgijoje, vienoje vertinimo sistemoje buvo kompleksiškai ịvertinta ekologinių rodiklių aibe ir parengtas alternatyvų vertinimas. Rumunijoje ir kitose šalyse, vertinant AT naudojimo alternatyvas, sprendimai priimti remiantis erdvinès analizès rezultatais, taikant GIS technologiją (Garcia-Ayllon 2018). Vokietijos mokslininkai vertinti AT problematiką siūlo nustatant vyraujančios vietovès paskirties tipo ir joje esančios AT rodiklių kombinacijas (Schädler et al. 2010).

Sékmingas PPP pavyzdys yra Liverpulio miestas. $2005 \mathrm{~m}$. šiame mieste esančiai Waterfront teritorijai (1.6 pav.) pertvarkyti ES ir Didžioji Britanija kartu su privačiu sektoriumi iš viso skyrẻ $560 \mathrm{mln}$. eurų.

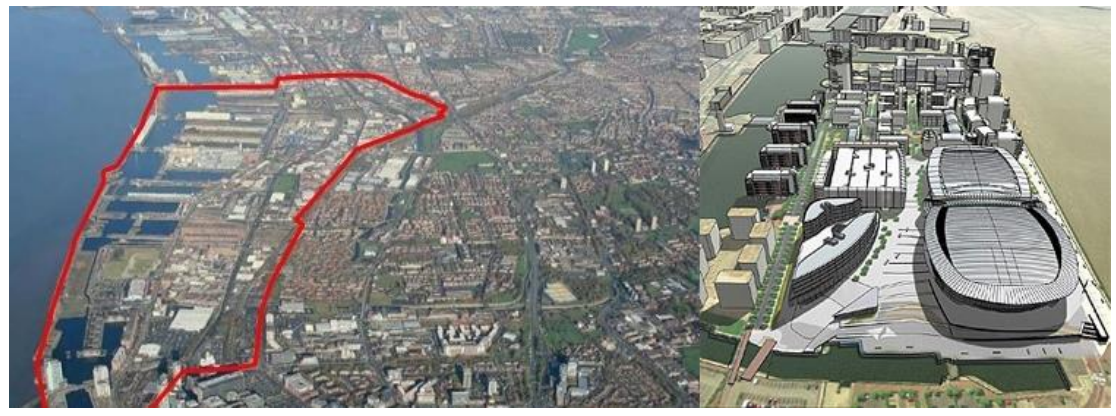

1.6 pav. Waterfront vietoveje esančių apleistų teritorijų paskirties pakeitimas ị mišrios paskirties zoną Liverpulyje (Maliene et al. 2012)

Fig. 1.6. Changes in the purpose of brownfields in the Waterfront area replacing brownfields areas with for the mixed functional area in Liverpool (Maliene et al. 2012)

Privataus ir viešojo kapitalo partnerystès principu (toliau- PPP) AT ir aplinkinèse nenaudojamose miesto teritorijose buvo sukurti verslo, poilsio kompleksai, kurie sudare mišrios paskirties teritorijas. Tokiu būdu buvo įsteigta apie 2500 naujų darbo vietų, sukurtas estetinis aplinkos vaizdas, renovuoti kai kurie senieji pastatai, taip išsaugotas istorinis aplinkos identitetu tapęs kultūros paveldas. Buvo ịrengta potvynių apsaugos sistema. Igyvendinus šiuos sprendinius, pastebèta, kad šios teritorijos vandens energiniai poreikiai ir vandens bei oro tarša gerokai sumažejjo (European Commission 2013; Maliene et al. 2012). 
Reprezentatyvus pramoninès paskirties AT paskirties keitimo kuriant pridètinę ekonominę naudą pavyzdys yra Niujorke. Ten $2006 \mathrm{~m}$. prasidejo 2,33 km ilgio geležinkelio trasos ir greta esančios teritorijos paskirties trys keitimo etapai. Jie igyvendinti per 12 metų. Darbai pabaigti 2014 m. (Kimmelman 2014, 1.7 pav.).

Šis projektas buvo igyvendintas taikant PPP finansavimo modelị (1.8 poskyris). Vienas sutvarkytas akras po paskutinio etapo kainavo apytikriai $29,6 \mathrm{mln}$. eurų, tai yra beveik didžiausia parko kaina žmonijos istorijoje. Didžioji dalis šios sumos yra privačios lèšos. Investuotojai ị šios teritorijos paskirties keitimą investavo kryptingai: dabar ten (Manhateno vakarinè dalis) ịkurtas 26 akrų ploto kelių milijardų eurų vertès architektūrinis kompleksas, apimantis zoologijos sodą, ypač aukštus verslo centrus ir gyvenamąsias zonas.

Nuo to laiko, kai prasidèjo pirmasis projekto etapas, nebuvo užregistruota nè vieno rimto kriminogeninio akto keičiamoje teritorijoje. Tai rodo, kad teritorijų paskirties keitimas, kaip teritorijų formavimo metodas, teikia ne tik ekonomę naudą, tačiau ir lemia tinkamą aplinką stiprinti socialinị imunitetą ir bendruomeninius ryšius (Wilson 2011).

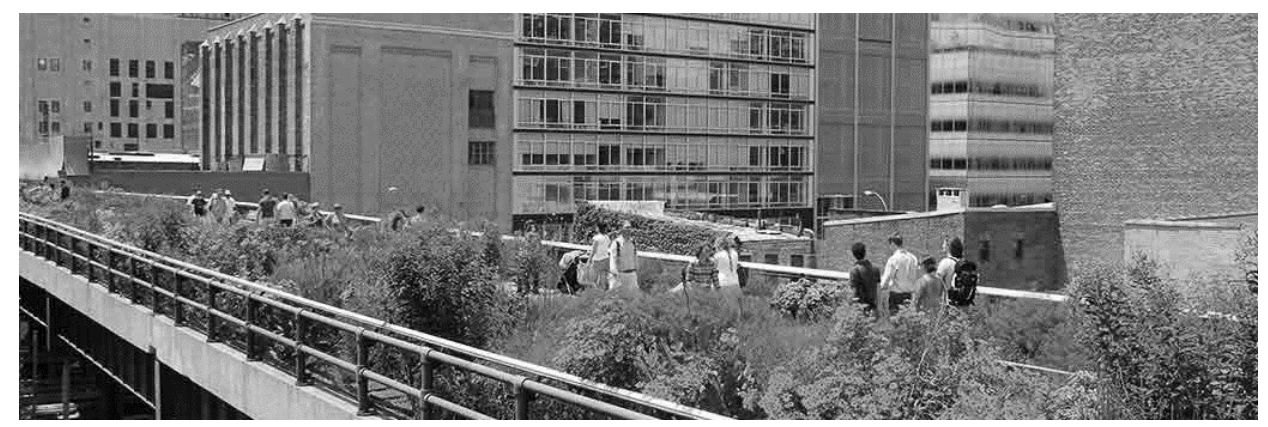

1.7 pav. Aukštuminès linijos (angl. High Line) pertvarkyta teritorija Niujorke (nuotrauka: Pinterest 2017)

Fig. 1.7. The redeveloped area of the High Line rail route in New York (Pinterest 2017)

Siekiant spręsti AT problemas, 2014 m. pradètas igyvendinti REVIT projektas, jungiantis Vokietiją, Prancūziją, Jungtinę Karalystę, Velsą ir Nyderlandus (EUGRIS 2005). Projekte teigiama, kad kompanijos, be techninių reikalavimų vykdymo, turi jausti ir socialinę atsakomybę arba nedalyvauti procese visai. Finansinis klausimas turi būti tik vienas iš rodiklių (Ertel et al 2008). Postsovietinèse šalyse AT problematika dèl ịtemptos finansinès padèties vis dar tebèra sunkiai ịveikiamas iššūkis. Šios priežastys lèmè, kad AT rodiklių atranka paremta pirmiau įvardytų Vakarų šalių ir kai kurių Rytų bloko šalių, tokių kaip Čekija ir Slovakija, patirtimi. 
Šiose šalyse didžiausi AT pertvarkymo procesai vyksta tik prioritetinėse ir planinio reguliavimo priemonemis atrinktose vidinèse miesto erdvèse (Frantal et al. 2015).

Teritorijų paskirties keitimas pagal teritorijos apimtị gali būti dviejų rūšių: atskirojo sklypo ir kompleksinė, apimanti keletą greta esančių sklypų. Remiantis postsovietinių šalių geraja patirtimi, AT turi būti vertinamos ir tvarkomos laikantis holistinio požiūrio ị AT pavojus ir neišnaudotas galimybes. Ši tvarka gali būti apibrèžta šiais nuosekliais etapais (1.8 pav.), pradedant nuo planavimo ir baigiant ịgyvendinimo etapu.

Praktikoje holistinio požiūrio principai dèl AT problematikos kompleksiškumo gali būti apibrèžti tik gan abstrakčiomis gairèmis. Todèl, sprendžiant AT problematiką ir mažinant keliamus pavojus, jų ịsisavinimo tvarką būtina reglamentuoti apibrèžus horizontaliąsias ir vertikaliąsias fazes. Toks AT tvarkos struktūrizavimas sudaro sąlygas nuosekliai vykdyti regeneracijos procesą, kartu įtraukti suinteresuotąsias šalis, jų keliamus tikslus, projekto igyvendinimo fazes ir galutinius gavejjus bei naudotojus (1.9 pav.).

Didžiosios Britanijos, Vokietijos ir Prancūzijos patirtis rodo, kad teritorijų kaitai itakos turèjo deindustrializacija, globalizacija, demografiniai pokyčiai ir pasenusi aplinkos urbanistinė struktūra. Dẻl šių reiškinių kiekvienoje iš šalių susiformavo tam regionui būdingu veiksnių nulemtos politinès priemonès, kurios atspindi pagrindinius nacionalinius prioritetus: socialinès atskirties mažinimas Prancūzijoje, teritorijų naudojimo tolygumas Vokietijoje, žemès naudojimo efektyvumas Didžiojoje Britanijoje (Masson 2018; Couch et al. 2011).

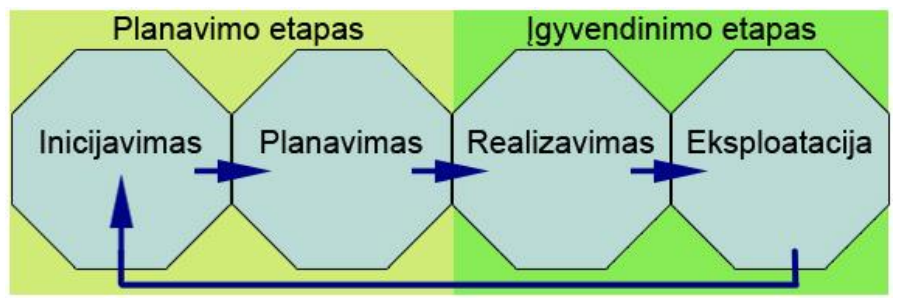

1.8 pav. Apleistų teritorijų pertvarkymo eigos etapai ir procesai pagal holistinio požiūrio principus (Norman et al. 2015)

Fig. 1.8. Brownfield transformation stages and processes in accordance with the principles of the holistic approach (Norman et al. 2015)

Buvusių karinių, pramoninių teritorijų mieste paskirties keitimas - tai vienas efektyviausių miesto tvarios plètros būdų. Užterštos AT iš piktžaizdžių tampa visavertemis miesto dalimis, pritraukiančiomis gyventojus atgal i miestą. Naudojantis esama miesto inžinerine, transporto, socialine infrastruktūra išvengiama didžiulių papildomų investicijų (Leitanaitė 2010). Butkus (2011) 
teigia, kad kaip kultūrinio miesto potencialo dalis yra rekreacinè miesto struktūra, kuri priklauso nuo miesto gyventoju laisvalaikio, sveikatos priežiūros ịpročiu, išsilavinimo ir kultūros tradicijų. Anot Butkaus (2011), rekreacinè miesto struktūra yra miesto kultūrinio potencialo dalis.

AT sutvarkymo planavimo fazès pagal prioritetą gali būti skirstomos nuo AT nustatymo iki įgyvendinimo ir išmoktų pamokų. Remiantis holistine samprata, šios fazès įvykdymas sudaro prielaidas kaupti gerają miesto arba šalies patirti ateities planavimo kultūrai, dialogui su vietos bendruomenėmis.

\begin{tabular}{|c|c|c|c|}
\hline Fazès & Informacijos resursai & $\begin{array}{l}\text { Informacijos } \\
\text { šaltiniai }\end{array}$ & Gavėjai \\
\hline $\begin{array}{l}\text { AT atpažinimas } \\
\text { (nustatymas) }\end{array}$ & $\begin{array}{l}\text { Vieta, rodikliai, infrastruktūra, } \\
\text { nuosavybè, planavimo sąlygos }\end{array}$ & $\begin{array}{l}\text { [ ISOORE: investiciniu } \\
\text { zonu DB, AT jirašai } \\
\text { su savybèmis }\end{array}$ & $\begin{array}{l}\text { Bendruomenè, } \\
\text { vietinè valdžia }\end{array}$ \\
\hline $\begin{array}{l}\text { Plètros } \\
\text { potencialas }\end{array}$ & $\begin{array}{l}\text { Proceso dalyviai, institucijos, } \\
\text { nuosavybès inventorius, vieta, } \\
\text { potencialūs finansavimo } \\
\text { saltiniai, paklausa, } \\
\text { aprūpinimas (tiekimas) }\end{array}$ & $\begin{array}{l}\text { I VIDŲ: investicinių } \\
\text { zonų DB - AT. AT } \\
\text { įrašai su savybėmis }\end{array}$ & $\begin{array}{l}\text { Investuotojai, } \\
\text { bendruomenè }\end{array}$ \\
\hline $\begin{array}{l}\text { Plany } \\
\text { rengimas }\end{array}$ & $\begin{array}{l}\text { Tikslai ir prioritetai, integruoti } \\
\text { veiksmų planai, idèjų bankas, } \\
\text { gairès ir rekomendacijos }\end{array}$ & $\begin{array}{l}\text { I VIDU: projektų DB, } \\
\text { inspiracijos, irankiai, } \\
\text { geriausia praktika, } \\
\text { dalyviu atsiliepimai }\end{array}$ & $\begin{array}{r}\text { Projektų } \\
\text { valdytojai, AT } \\
\text { valdytojai, } \\
\text { suinteresuotos } \\
\text { šalys }\end{array}$ \\
\hline \multirow[t]{2}{*}{$\begin{array}{l}\text { Žemès } \\
\text { paruošimas ir } \\
\text { vystymas }\end{array}$} & $\begin{array}{l}\text { Atgaivinimo potencialas, } \\
\text { žemès ir viešosios erdvès, }\end{array}$ & $\begin{array}{l}\text { i VIDU: projektų DB, } \\
\text { iniciatyvos }\end{array}$ & \multirow{2}{*}{$\begin{array}{r}\text { Investuotojai, } \\
\text { suinteresuotos } \\
\text { šalys }\end{array}$} \\
\hline & $\begin{array}{l}\text { vystymo metodai, visuomenès } \\
\text { dalyvavimas ir informacija }\end{array}$ & | IŠORE: medija & \\
\hline \multirow[t]{2}{*}{ Igyvendinimas } & $\begin{array}{l}\text { Projekto planas, užbaigimo } \\
\text { rezultatai }\end{array}$ & | IŠORE்: medija & $\begin{array}{r}\text { Suinteresuotos } \\
\text { šalys }\end{array}$ \\
\hline & $\begin{array}{l}\text { Projekto būsena ir užbaigimas, } \\
\text { geriausia praktika, inovacijos, } \\
\text { išmoktos pamokos }\end{array}$ & I IŠORE: AT DB & $\begin{array}{r}\text { Suinteresuotų } \\
\text { šallių ateitis, AT } \\
\text { valdymas } \\
\end{array}$ \\
\hline
\end{tabular}

1.9 pav. Apleistų teritorijų sutvarkymo įtraukiant dalyvius, etapus ir užduotis fazès ir procesai (Cobraman project 2012, sudaryta autoriaus)

Fig. 1.9. The phases and processes of brownfields redevelopment involving interest parties, stages and tasks (Cobraman project 2012, created by author)

AT tvarkyti taikant paskirties keitimą siekiant darnios miesto plètros, turi būti numatomi veiksmai:

- žemès galutinès paskirties parinkimas;

- paskirties keitimo procedūros parinkimas; 
- tolesnio teritorijos naudojimo vizija, teritorijos atrinkimas, integravimo i bendrą urbanistinį karkasą strategija.

I procesų užbaigimo etapą, priklausomai nuo AT savybių ir keliamų tikslų, gali būti ịtraukiami aplinkos apsaugos, kultūros paveldo, vadybos ir valdymo, ekonomikos, finansų ir teritorijų planavimo specialistai.

Siekiant kurti pridètinę vertę ateities AT naudojimo sprendiniams, stambiausių Europoje AT paskirties keitimo projektų aprašymai su duomenimis viešai prieinami ES inicijuoto TIMBRE projekto medžiagoje (TIMBRE 2012).

\subsection{Demokratinio ir strateginio planavimo pavyzdžiai}

Didžioji Britanija - viena iš nedaugelio šalių, kuri turi ilgalaikę žemès naudojimo politiką, naujo AT naudojimo paramos politiką bei programas. Šalyje egzistuoja atidus naujo AT naudojimo monitoringas valstybès lygmeniu.

Centralizuota planavimo sistema, naudojant žaliuosius žiedus (1.10 pav.), Didžiojoje Britanijoje padejo sustabdyti didžiujų miestų ekspansiją i periferiją, taip skatinant apleistas miestų vietas naudoti naujoms statyboms. Nors Vokietijos patirtis parodè, jog tokia planavimo sistema ne visais atvejais duoda norimą rezultatą, tačiau sudaro sąlygas lengviau nustatyti miestų sklaidos ị periferinę zoną pobūdị. Vilniaus mieste periferinè zona sudaro apie 11,2 tūkst. ha.

Didžiojoje Britanijoje ir Vokietijoje kontroliuoti miestu plètrą ir palaikyti tinkamas sąlygas perorganizuoti dykras taikomas centralizuotas miestų planavimo modelis, kuris daugeliu aspektų yra sėkmingas. Viena didžiausių kliūčių, su kuria susidūrè Didžiosios Britanijos sprendimų vykdytojai, yra nuosavybės teisès perėmimas. Tai lėmè situaciją, kai, nepaisant didelès apimties parengtų analizių ir projektų, konkretūs sprendiniai liko neiggyvendinti arba jų igyvendinimas buvo atidètas (Adams et al. 2010).

Oficiali šių šalių statistika rodo, kad nuo 2008 m. Didžiojoje Britanijoje net 77 \% naujų namų pastatyta ankstesnèse miestų dykrose, kai šis skaičius $1996 \mathrm{~m}$. siekė tik $57 \%$. Vokietijoje pagrindinè žemès naudojimo statistika išryškina bendraji miestų augimą, įskaitant ir transporto sistemoms skirtas teritorijas. Lyginant tarpusavyje šių šalių statistinius duomenis, apskaičiuota, kad miestų periferinis plètimasis (plečiant administracines ribas) Vokietijoje buvo 4 kartus spartesnis negu Anglijoje (atitinkamai 6,7\% ir 1,8\%) nuo $1990 \mathrm{~m}$. iki $2000 \mathrm{~m}$. Bendroji žemès apimtis šiuo laikotarpiu Vokietijoje sieké 174,4 tūkst. ha. Tuo pačiu metu Anglijoje - tik 30,4 tūkst. ha, t. y. beveik 6 kartus mažiau. Europos Komisija (2013), komentuodama šią situaciją, teigia, kad Didžiojoje Britanijoje miestų planavimo politika yra daug griežtesnė negu Vokietijoje, o žaliojo žiedo koncepcija sulaukè didelio visuomenès palaikymo. 


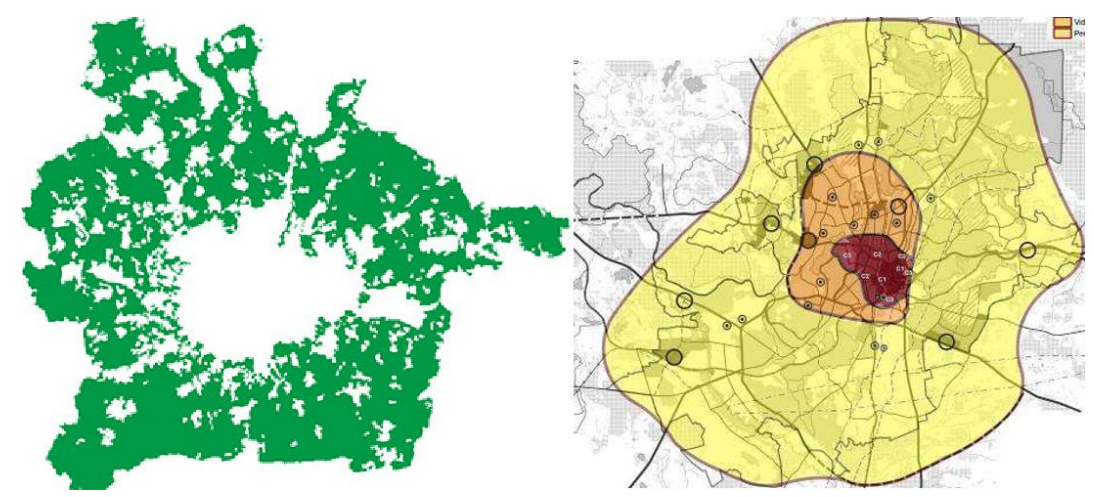

1.10 pav. Londono žaliasis žiedas (kairèje) ir Vilniaus periferinè zona (dešinèje)

Fig. 1.10. London Green belt (left) and the peripherial zone of Vilnius (right)

Skirtingus centralizuoto miestų planavimo rezultatus taip pat lėmė įvairiapusė politinè aplinka, požiūris ị miestų plètimąsi ir ypač ị jos padarinius. Kai žaliujų žiedų planavimo metu Didžiosios Britanijos miestuose buvo taikyta ,izoliavimo“ politika, Vokietijoje taikyta strateginè miestų plètra i kaimo vietovių ribas ieškant kompromisu su žemès valdytojais. Taigi, skirtingai negu Didžiosios Britanijos miestuose, Vokietijoje nebuvo jokios žaliụjų miestų žiedų alternatyvos. Todẻl miestų plètros laisvè buvo iš esmès nelygiavertè. Tik $2002 \mathrm{~m}$. Vokietijos politikai atkreipé dèmesi i galimą tokios plètros žalą. Tačiau žemesnès instancijos savivaldos pakluso aukštesnio rango valdžios institucijoms ir jų priimtai politikai.

Skirtingose pasaulio šalyse dominuojantys miesto aplinkos veiksniai lemia AT tvarkymo strategiją ir gaires. Darbe apibrèžtos Vilniaus miesto AT sutvarkymo gairès pagal tuos pačius miesto aplinkos bruožus gali būti taikomos ir kituose Centrinès ir Rytų Europos miestuose.

\subsection{Apleistų teritorijų mastas Lietuvoje}

Atliekant Vilniaus miesto esamos būklès vertinimą ir susiejant užfiksuotus geoerdvinius duomenis su TPSIS (2015) pateiktais duomenu rinkiniais, pavyko nustatyti, kad AT mastas (2.7 pav.) vizualiai yra didesnis, nei deklaruojama BP sprendiniuose. Šią problemą dar 2007 m. iškèlè Leitanaitè (2007).

AT skaičius Lietuvoje buvo fiksuojamas 2011-2015 m. Paskutiniais fiksavimo metais jų priskaičiuota $700 \mathrm{~km}^{2}$ (70 tūkst. ha). Iš 1.10 paveiksle pateiktų duomenų matyti, kad didžiausias jų skaičius (beveik $80 \mathrm{~km}^{2}$, t. y. 8 tūkst. ha) yra susitelkęs Vilniaus miesto periferinèse zonose ir apskrityje.

Nepaisant subjektyvaus AT matavimo technologijos, šiuos istorinius duomenis reikia paaiškinti. Šią tendenciją galima argumentuoti pastaraji 
dešimtmetị vykstančia sparčia Vilniaus miesto urbanizacija, ypač gyvenamojo būsto fondo sąskaita, naujų statybos projektų apimties rengimu (ir įgyvendinimu) bei urbanistiniu poveikiu aplinkinėms gyvenvietėms. AT kiekio matavimai leidžia pažvelgti i jų apimtis nacionaliniu lygmeniu ir išryškina prioritetą AT keliamas problemas ir iššūkius nagrinèti Vilniaus miesto kontekste. Kita vertus, AT sklaidos kitimą galima gretinti su vietos ekonominių rodikliu gerejjimu atskiruose šalies rajonuose. Pavyzdžiui, galima kelti prielaidą, kad AT skaičiaus prieaugis periferinèse Vilniaus miesto zonose išryškina ekonominio potencialo erdvę naujiems verslams ir naujoms darbo vietoms sukurti.

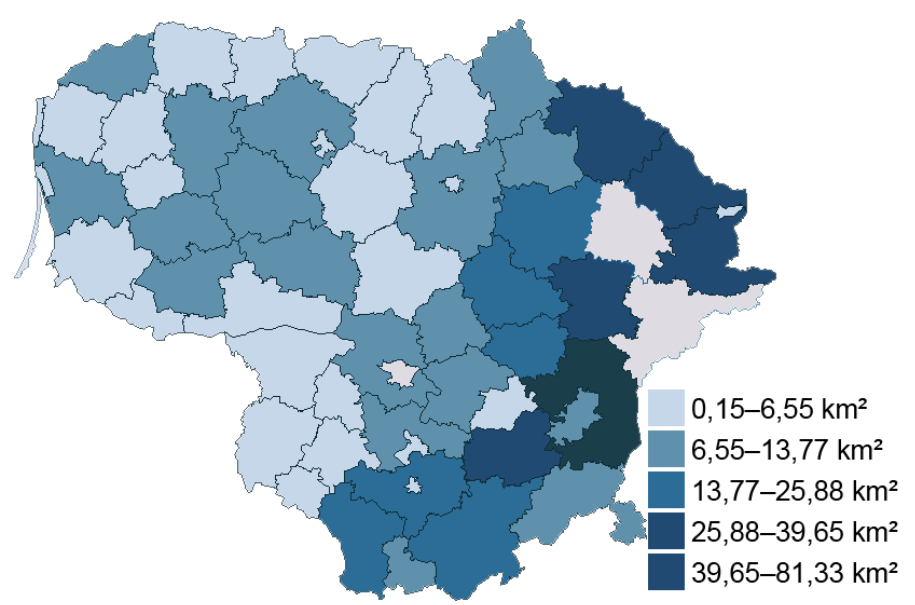

1.11 pav. Apleistų teritorijų pasiskirstymas Lietuvoje pagal rajonus $2015 \mathrm{~m}$. (TPSIS 2015) Fig. 1.11. The distribution of brownfields by the regions of Lithuania in 2015 (TPSIS 2015)

Penkerių metų laikotarpiu dèl suintensyvèjusių statybų AT Lietuvoje sumažèjo beveik du kartus (1.4 lentelè). Šis procesas sparčiausiai vyko mažesnès vertès periferinèse miesto zonose, kurios anksčiau prarado savo funkciją, tačiau buvo tinkamos vykdyti statybas papildomai teritorijos neišvalant. Dalyje šių teritorijų jau prasidèję paskirties keitimo procesai, tačiau jie nèra greiti ir efektyvūs.

1.4 lentelè. Apleistų teritorijų skaičiaus kaita Lietuvoje 2011-2015 m. (TPSIS 2015)

Table. 1.4. Changes of amount of brownfields areas in Lithuania between 2011 and 2015 (TPSIS 2015)

\begin{tabular}{|l|c|c|c|c|c|}
\hline Metai & 2011 & 2012 & 2013 & 2014 & 2015 \\
\hline AT kiekis, $\mathrm{km}^{2}$ & 1421,96 & 1421,96 & 1357,62 & 768,24 & 699,95 \\
\hline
\end{tabular}


Taikant skirtingą AT nustatymo būdą, jas apibūdinantys statistiniai dydžiai gali skirtis. 2013 m. dèl netikslumų kilęs sąmyšis šias žemes vertinti pagal palydovo darytas aerofotonuotraukas sukèlè prielaidas abejoti pateiktais duomenimis. Mokslinè patirtis atskleidè, kad praktikoje toks matavimo būdas yra vienas netiksliausių (1.5 lentelè).

Didžiausi netikslumai nustatyti vertinant žemės ūkio paskirties teritorijas. Dèl registre aptiktų apleistų žemių neatitikčių, apie 80 \% ūkininkų, kuriems reikejjo mokèti didesni žemès mokestį, susidūrè su laikinais žemès eksploatavimo suvaržymais.

1.5 lentelė. Apleistų teritorijų stebėsenos metodų vertinimas (Kuliešis et al. 2011)

Table 1.5. The Assessment of monitoring methods for brownfields (Kuliešis et al. 2011)

\begin{tabular}{|l|l|l|l|}
\hline Veiksniai & Matavimai & Aerofotografavimas & Palydovinès nuotraukos \\
\hline Tikslumas & Iki $10 \mathrm{~cm}$ & $2-3 \mathrm{~m}$ & $2-10 \mathrm{~m}$ \\
\hline Išlaidos & Didelès & Vidutinės & Mažos \\
\hline Laiko sąnaudos & Didelès & Didelès & Mažos \\
\hline Objektyvumas & Subjektyvu & Subjektyvu & Objektyvu \\
\hline Dažnumas & Viena patikra & $3-5 \mathrm{~m}$ periodas & Sezoninis ir 3 m istorija \\
\hline
\end{tabular}

Lietuvoje paplitęs AT matavimo būdas sunkiai pritaikomas urbanizuotose teritorijose, kur būtina kokybinè apžiūra, socialinis, ekonominis ir gamtinis vertinimas.

\subsection{Viešojo ir privataus sektorių partnerystès modelis, taikomas apleistų teritorijų paskirčiai keisti}

Keičiantis rinkos sąlygoms, NT analitikai pažymi, kad pastaraisiais metais gyventojų migracija i periferines miestų zonas slopsta. Atlikus papildomas apklausas siekiant sužinoti visuomenès nuomonę, nustatyta, kad dèl lengvai pasiekiamos išplètotos socialinès ir dar sovietmečiu sukurtos inžinerinès infrastruktūros gyventojai vis dažniau renkasi būstus arčiau miesto centro. Praktika rodo, kad periferinèse zonose panaudoti esamą miesto inžinerinę infrastruktūrą yra ekonomiškai naudingiau negu tiesti naują. Siekiant racionalizuoti teritorijų planavimą ir naujos infrastruktūros plètrą, būtina ne tik subalansuoti miestų planavimo ir plètros metodus, bet ir nustatyti galimus finansinius saugiklius, perimti gerosios praktikos pavyzdžius iš užsienio šalių (Sharma, Newman 2018; Li et al. 2018).

Galimi du pagrindiniai AT atkūrimo finansavimo šaltiniai: 
- privatūs investuotojai;

- viešieji šaltiniai;

- galimos pirmojo ir antrojo šaltinių kombinacijos (Geddes, Reeves 2017; Jackson et al. 2010).

Lietuvoje PPP taikyti imta tik $2010 \mathrm{~m}$. Tada ịsigaliojo LR investicijų ịstatymo ir susijusių teisès aktų nuostatai, kurie tapo teisiniu pagrindu rengti ir igyvendinti PPP projektus (Centrinè projektų valdymo agentūra 2014).

Lietuvoje apleistu pastatų likvidavimo programa finansuojama iš ES struktūrinių ir viešujų fondų. Ši programa apima tik rajonų savivaldybių valdomas teritorijas, kurioms Vyriausybe kiekvienais metais skiria apie 600 tūkst. eurų apleistiems pastatams ir teritorijoms tvarkyti (LR aplinkos ministerija 2008). ES finansinių investicijų laikotarpiu per Vidaus reikalų ministerijos (toliau - VRM) priemones buvo skirta 138,4 mln. eurų investicijų penkioms didžiųjų Lietuvos miestų viešosioms erdvèms ir AT tvarkyti. Tai lèmè spartų AT skaičiaus Lietuvoje sumažèjimą (1.5 lentelè) per paskutinius penkerius metus. Skaičiuojama, kad Lietuvoje artimiausius kelerius metus investicijoms, skirtoms infrastruktūrai modernizuoti ir gerinti, reikia daugiau kaip $350 \mathrm{mln}$. eurų.

Rengiant teritorijų pertvarkymo ir miestų plètros projektus, didžiausiu iššūkiu tampa finansavimo klausimas. Potencialūs investuotojai linkę mažai investuoti i AT tvarkymą, o savivaldybėms tokias žemes turèti ir atgaivinti dažnai finansiškai nenaudinga. Pasaulinè patirtis rodo, kad viešojo sektoriaus infrastruktūros objektams atnaujinti plačiai taikomas PPP (1.12 pav.) modelis (BertoméuSánchez et al. 2018; Rouhani et al. 2018; Polyakova 2016).

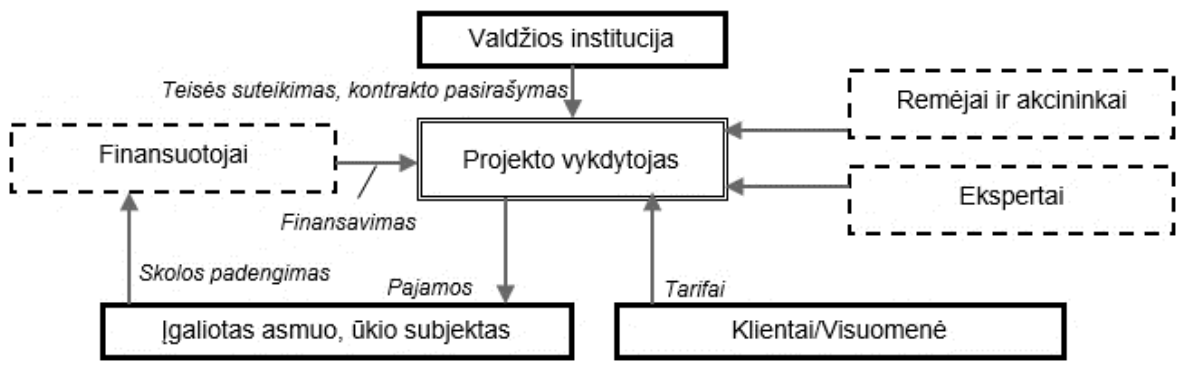

1.12 pav. Privataus ir viešojo sektoriaus partnerystès veikimo schema (United Nations ESCAP 2011)

Fig. 1.12. A scheme for a collaborative Private and Public Partnership (United Nations ESCAP 2011)

Privataus kapitalo ịsitraukimas į AT atkūrimą yra ankstesnio savininko pozicijos išraiška. Jis rinkos ar kitomis sąlygomis igaliotas atkurti AT. Kita finansavimo galimybė - privataus investuotojo, kaip naujojo savininko, kurio 
tikslas - AT ịkurti verslą, indèlis (Glumac et al. 2015; Roig, Soriano 2015; Guzmán, Sierra 2012; Weihe 2005).

PPP projektai igyvendinami nuosekliais žingsniais: pasirinkus PPP objektą ir privatų subjektą, pasirašoma PPP sutartis ir pradedamos pirminès investicijos bei statybos ar tvarkymo darbai. Baigęs statybos ar tvarkymo darbus per numatytą laikotarpi, privatus sektorius teikia paslaugas ar užsiima komercine veikla pagal sutartyje numatytas sąlygas. Pasibaigus PPP sutartyje numatytam terminui, turtas perduodamas viešajam subjektui (Kaklauskas et al. 2012). Lietuvoje tokiu principu pastatytų, rekonstruotu arba šiuo metu statomų (arba parengti dokumentai statybai) viešosios ir socialinès infrastruktūros, švietimo įstaigų, pramogų ir kitų miestų gyventojų poreikius tenkinančių objektų nuo $2010 \mathrm{~m}$. priskaičiuojama 19. Iš jų Vilniuje - tik 4 (PPP Lietuva 2018).

Iš pradžių PPP projektai neatrodo pigiausias pasirinkimas, tačiau per ilgą laikotarpi (paprastai 25 metai) toks modelis dažniausiai atsiperka. Tokiuose projektuose pritaikoma privataus sektoriaus turima patirtis ir naudojamas jo kapitalas, todèl eksploatuojant turtą, valstybès sąnaudos gali būti net kelis kartus mažesnès. Dèl šios priežasties, laikui bėgant, valstybė sutaupo, verslo subjektai gauna ekonominę naudą, o visuomenè ịgyja naują infrastruktūrą mieste: parkus, skverus, aikštes, reikalingas paslaugas, patrauklią gyvenamają aplinką, būstą ir kitus gyvenimo kokybę lemiančius miesto erdvès elementus.

Priežastinio ciklo schema (1.13 pav.) išryškina AT pertvarkymo priklausomybę nuo skirtų lèšų. Praktika rodo, kad AT pertvarkymo kaštai tampa mažesni, kai parenkamas komercinès zonos paskirties keitimo scenarijus (BenDor et al. 2011).

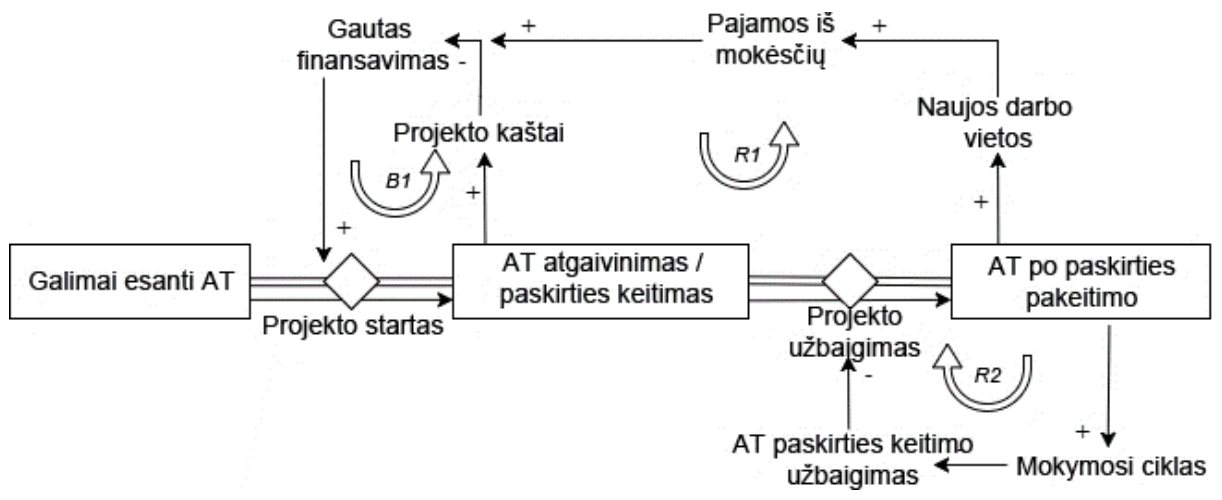

1.13 pav. Dinaminès hipotezės modelis, skirtas sėkmingam ekonominiam modeliui numatyti (sudaryta autoriaus)

Fig. 1.13. A model for a dynamic hypothesis on the presumed successful economic model (created by author) 
Mokslininkai, nagrinėjantys gerają ir blogają PPP patirtị lemiančius veiksnius (Kumar et al. 2018; Koppenjan, Enserink 2009), išskiria, kad dažniausi blogosios patirties rizikos veiksniai yra šie: investuotojų monopolio suformavimas, dèmesio stoka partneriams, nepakankamas dèmesys darniosios plètros veiksniams, efektyviam išteklių naudojimui ir kt.

Planuojant ilgalaikès perspektyvos inžinerinès infrastruktūros sprendinius, tai ekonomiškai efektyvesnis sprendimas: vieno tiesinio kilometro asfaltbetonio dangos konstrukcija atsieina 435-580 tūkst. eurų, o didžiausią ịtaką bendram kelių ilgio padidejjimui turejjo miestų, gyvenviečių ir naujų gyvenamujų rajonų plètra. Naujo vartotojo prisijungimas prie elektros tinklų $80 \%$ kompensuojamas iš tinklo sąskaitų. Vadinasi, už vartotojų prisijungimą sumoka esami vartotojai (Laurinènaitè-Šimelevičienè 2012).

Užsienio praktika rodo, kad prie aktyvių poilsio zonų, kuriose ịrengti treniruokliai, riedučių ir riedlenčių aikštele arba pastatyta vaikų žaidimų aikštelè, būsto vertè auga apie 5-10\%. Ramybès poilsio zonų (pasyvių žaliụu zonų) prieigose NT gali būti brangesnis net iki $20 \%$. AT esančių žaliujų zonų prieigose privatus kapitalas gali lemti esmines šios vietovès transformacijas plečiant ir parduodant NT ir taip sukurti tinkamą socialinę aplinką gyventojams.

Ši praktika rodo, kad PPP modelis suteikia sąlygas prikelti AT ir sukurti naują viešają ir inžinerinę infrastruktūrą. Nors PPP modelis Lietuvoje gilių tradicijų neturi, tačiau, sprendžiant AT keliamus pavojus ir įvertinus galimą naudą, šis būdas vertinamas kaip vienas svarbiausių.

\subsection{Apleistụ teritorijų naujos paskirties naudojimo patirtis Lietuvoje}

Lietuvos miestuose AT paskirties keitimo procesai suaktyvejo atkūrus nepriklausomybę ir privačiam kapitalui iš esmès prisidejjus prie miestu plètros. Dẻl besąlygiškai teigiamai vertintų investicijų i miesto plètros procesus išryškejjo žalingos teritorijų paskirties keitimo tendencijos (Matulevičius, Šliogerienė 2011). Investuotojams labiausiai rūpejjo patogiose miesto vietose esančios viešosios erdvės, kurių vietoje imta planuoti komercinių ir gyvenamujjų kompleksų zonos. Tokiu būdu sunaikintos prieš tai buvusių visuomeninių teritoriju funkcijos. Taršios pramoninès ir karinès teritorijos nebuvo patrauklios investuoti i jų pertvarkymą, todèl buvo apleistos ir nenaudojamos.

Kaip blogus teritorijų paskirties keitimo pavyzdžius Drèmaitė (2004) išskiria buvusio „Žalgirio“ stadiono vietoje ịrengtą prekybos centrą Kaune, prekybos centro „Akropolis“ plètrą Ozo draustinio teritorijoje ir kt. Didesni atgarsị visuomenèje sukèlè buvusio „Žalgirio“ stadiono Vilniuje paskirties keitimas $\mathfrak{i}$ 
mišrios paskirties (gyvenamąą ir komercinę) zoną. Kai privataus verslo subjektas įsigijo šį sklypą, projektui numate skirti apie $200 \mathrm{mln}$. eurų.

Vienas daugiausia teigiamų atsiliepimų iš miestų planuotojų pastaraisiais metais sulaukęs teritorijos paskirties keitimo atvejis yra Kaune. Čia privataus verslo subjektas įsigijo AT ( 0,85 ha) kartu su joje nebaigtu statyti „Respublikos“ viešbučiu (26 tūkst. $\mathrm{m}^{2}$ ), kuri demontavus, su šalia esančia teritorija numatyta keisti paskirtị ị verslo ir komercijos. Paskirties keitimo procesus numatyta atlikti i̊rengiant susisiekimo, inžinerinę ir socialinę infrastruktūrą.

Didžiausios apimties AT paskirties keitimo projektai Vilniaus, Kauno ir Klaipėdos miestuose pateikti 1.6 lentelëje. Teritorijų vieta Vilniaus mieste vertinta pagal 1.8 paveiksle pateiktą schemą skirstant teritorijas $i$ atskirus tipus pagal joms tenkantị gyventojų skaičių ir atstumą nuo miesto centro.

1.6 lentelè. Pastarojo dešimtmečio apleistų teritorijų žemès paskirties keitimo atvejai Lietuvoje iki $2016 \mathrm{~m}$. (sudaryta autoriaus)

Table 1.6. Real cases of changes in the purpose of brownfield land use in Lithuania for the last decade up to 2016 (created by author)

\begin{tabular}{|c|c|c|c|}
\hline $\begin{array}{l}\text { Teritorija pakeitus } \\
\text { paskirti }\end{array}$ & $\begin{array}{l}\text { Teritorija prieš } \\
\text { keičiant paskirties }\end{array}$ & Vieta mieste & $\begin{array}{l}\text { Teritorijos funkcija } \\
\text { pakeitus paskirti }\end{array}$ \\
\hline 1 & 2 & 3 & 4 \\
\hline $\begin{array}{l}\text { Prekybos centras } \\
\text { „Panorama““ }\end{array}$ & $\begin{array}{l}\text { Vilniaus pieno } \\
\text { kombinatas }\end{array}$ & $\begin{array}{l}\text { Centrinè miesto } \\
\text { dalis (I tipas) }\end{array}$ & $\begin{array}{l}\text { Komercinès } \\
\text { teritorijos }\end{array}$ \\
\hline $\begin{array}{l}\text { Gyvenamujų namų } \\
\text { kompleksas „Ozo } \\
\text { namai““ }\end{array}$ & Sandèliai & $\begin{array}{l}\text { Seniūnijos cen- } \\
\text { tras, } 4-5 \mathrm{~km} \text { nuo } \\
\text { miesto centro (II } \\
\text { tipas) }\end{array}$ & $\begin{array}{l}\text { Vidutinio užstatymo } \\
\text { gyvenamoji } \\
\text { teritorija }\end{array}$ \\
\hline $\begin{array}{l}\text { Šiaurès miestelio } \\
\text { kvartalas }\end{array}$ & $\begin{array}{l}\text { Tanku dalinio kari- } \\
\text { nės bazès teritorija }\end{array}$ & $\begin{array}{l}\text { Seniūnijos } \\
\text { centras (II tipas) }\end{array}$ & $\begin{array}{l}\text { Komercinès } \\
\text { teritorijos }\end{array}$ \\
\hline $\begin{array}{l}\text { Gyvenamujų namų } \\
\text { kompleksas } \\
\text { „Šaltinių namai““ }\end{array}$ & $\begin{array}{l}\text { „Komunaro“" } \\
\text { staklių gamykla }\end{array}$ & $\begin{array}{l}\text { Centrine miesto } \\
\text { dalis, Senamiestis } \\
\text { (I tipas) }\end{array}$ & $\begin{array}{l}\text { Vidutinio užstatymo } \\
\text { gyvenamoji terito- } \\
\text { rija }\end{array}$ \\
\hline $\begin{array}{l}\text { Gyvenamujų namų } \\
\text { kompleksas „Loft } \\
\text { town“ }\end{array}$ & $\begin{array}{l}\text { Kuro aparatūros } \\
\text { gamyklos pastatai } \\
\text { ir teritorijos }\end{array}$ & $\begin{array}{l}\text { Viena pagrindinių } \\
\text { miesto susisieki- } \\
\text { mo arteriju, } 3 \mathrm{~km} \\
\text { nuo miesto centro } \\
\text { (II tipas) }\end{array}$ & $\begin{array}{l}\text { Mišrios (verslo, } \\
\text { gamybos, } \\
\text { gyvenamosios) } \\
\text { paskirties teritorijos }\end{array}$ \\
\hline $\begin{array}{l}\text { Gyvenamujų namų } \\
\text { kompleksas „Nauja- } \\
\text { miesčio namai““ }\end{array}$ & $\begin{array}{l}\text { Duonos kepykla } \\
\text { „Vilniaus duona“ }\end{array}$ & $\begin{array}{l}\text { Centrine miesto } \\
\text { dalis, Senamiestis } \\
\text { (I tipas) }\end{array}$ & $\begin{array}{l}\text { Mišrios (verslo, } \\
\text { gyvenamosios) } \\
\text { paskirties teritorijos }\end{array}$ \\
\hline
\end{tabular}


1.6 lentelès pabaiga

\begin{tabular}{|l|l|l|l|}
\hline \multicolumn{1}{|c|}{1} & \multicolumn{1}{|c|}{2} & \multicolumn{1}{|c|}{3} & \multicolumn{1}{c|}{4} \\
\hline $\begin{array}{l}\text { Ekspozicijų erdve } \\
\text { „Titanikas“ }\end{array}$ & $\begin{array}{l}\text { Spaustuvės } \\
\text { „Tiesa“ pastatai ir } \\
\text { teritorija }\end{array}$ & $\begin{array}{l}\text { Centrine miesto } \\
\text { dalis, senamiestis } \\
\text { (I tipas) }\end{array}$ & $\begin{array}{l}\text { Senamiestis, mišri } \\
\text { paskirtis }\end{array}$ \\
\hline Kultūros fabrikas & Tabako fabrikas & - & $\begin{array}{l}\text { Senamiestis, mišri } \\
\text { paskirtis }\end{array}$ \\
\hline $\begin{array}{l}\text { Viešbutis „Europa } \\
\text { Royal Kaunas“ }\end{array}$ & $\begin{array}{l}\text { Spaustuvė }, \text { Spindulys“ } \\
\text { Karaliaus }\end{array}$ & - & $\begin{array}{l}\text { Senamiestis, mišri } \\
\text { komercine, } \\
\text { gyvenamoji) } \\
\text { paskirtis }\end{array}$ \\
\hline $\begin{array}{l}\text { Mindaugo } \\
\text { apartamentai }\end{array}$ & $\begin{array}{l}\text { Kauno pieno } \\
\text { kompleksas }\end{array}$ & - & $\begin{array}{l}\text { Senamiestis, mišri } \\
\text { komercine, } \\
\text { gyvenamoji) } \\
\text { paskirtis }\end{array}$ \\
\hline
\end{tabular}

Iki 2014 m., kai buvo patvirtintos Teritorijų planavimo normos, atskira miestų planavimo ir plètros priemonè nebuvo nagrinèjama ir reglamentuojama miestų teritorijų planavimo dokumentuose. Taip yra ir Vilniaus miesto BP iki 2015 m., kuriame nors toks miesto plètros būdas pripažintas vienu iš prioritetinių, tačiau nèra parengta atskiros dalies, apibrèžiančios teritorijų paskirties keitimo reikalavimus. Lietuvoje, lyginant su kitomis Europos ir pasaulio šalimis, pasigendamas architektų, savivaldybių, miestų planuotojų ir kitų miesto plètros procesais suinteresuotų šalių požiūris ị darnią ir ekologišką plètrą (Sassi et al. 2009). Teritorijų planavimo normose (2014) išskiriami šie teritorijos paskirties keitimo tikslai:

- didinti miestų ir kitų gyvenamujų vietovių funkcinès ir fizinès struktūros integralumą;

- sudaryti sąlygas mažinti taršą;

- kurti palankią aplinką investuoti;

- tolygiau išdèstyti gyvenamąsias teritorijas ir darbo vietas;

- sukurti aplinkos, užstatymo, susisiekimo sistemos ir inžinerinès įrangos atnaujinimo sąlygas urbanizuotoje gyvenamosios vietovès dalyje.

Šiose taisyklèse rekomenduojama, kad, organizuojant miesto planavimą, $20 \%$ teritorijos būtų skirta išorinei plètrai, o likusi dalis - vidiniam miestų erdvès pertvarkymui (modernizacija, žemès paskirties keitimas).

AT pritaikymas pagal gyvenamają paskirtį turi būti siejamas su rekreacinès aplinkos (žaliosios zonos, sporto aikštynai ir kt.) prieinamumu. NT ekspertų teigimu, kuo arčiau žaliujų erdvių yra būstas, tuo jis brangesnis. Skaičiavimai parodè, kad Vilniuje žaliosios erdvès užima net $45 \%$ miesto ploto. Tai yra 
daugiau nei Berlyne, Londone ar Paryžiuje. Tačiau tiek NT plètotojai, tiek kraštovaizdžio architektai teigia, kad sostinès potencialas nèra išnaudotas. Šios zonos vertinamos kaip didžiausią žalą miesto įvaizdžiui ir gyventojų gyvenimo kokybei darantys urbanistinio karkaso komponentai. Atlikti skaičiavimai parodè, kad net $34 \%$ AT yra susitelkusios žaliujų erdvių plotuose.

\subsection{Pirmojo skyriaus išvados ir disertacijos uždavinių formulavimas}

1. Literatūros analizè parodè, kad apleistų teritorijų keliamos problemos nagrinėjamos tvaraus urbanizmo požiūriu. Literatūros analizė atskleidè, kad apleistų teritorijų tvarkymas, orientuotas ị naujos paskirties kūrimą, Lietuvoje prasidejjo tik pastaraji dešimtetį ir iki šiol nėra nusistovejjusių tokių teritorijų sutvarkymo tradicijų.

2. Taikant kompiuterinius klasifikacijos metodus, galima vykdyti automatizuotą apleistų teritorijų klasifikavimą pagal nustatytus socialinius, ekonominius, gamtinius ir urbanistinius rodiklius.

3. Apleistoms teritorijoms būdinga tipologija, pagal kurią jos suskirstytos ị savaime atsinaujinančias, ekonomiškai patrauklias ir tinkamas miesto rezervui erdves. Atlikus literatūros analizę, išskirtos trys pagrindinès apleistų teritorijų poveikio rūšys: ekologinè, ekonominė ir socialinė. Apleistų teritorijų paskirties keitimo scenarijai gali būti vertinami per šių poveikių prizmę, jų veikiamus veiksnius.

4. Atlikus Lietuvos skaitmenintų duomenų analizę nustatyta, kad apleistos teritorijos skirtinguose šaltiniuose apibūdinamos nevienodomis sąvokomis (apleista žemė, dykra ir kt.) ir fiksuojamos skirtinga matavimo technika: aerofotografavimas, fizinė apžiūra ir kt. Toks neabiprèžtumas sudaro prielaidas neịtraukti ị tyrimus visų registruojamų duomenų ir juos tikslinti.

5. Anksčiau igyvendintų apleistų teritorijų sutvarkymo projektų Lietuvoje ir užsienio šalyse analizè atskleide, kad privataus kapitalo ịsitraukimas sudaro palankias sąlygas pakeisti apleistų teritorijų paskirtị mažesniais savivaldybès kaštais.

Darbo tikslui pasiekti formuluojami šie uždaviniai:

1. Taikant geografines informacines sistemomas (GIS) ir statistinius metodus sukurti apleistų teritorijų savybes apibūdinančių rodiklių skaitinių reikšmių duomenų bazę (DB). 
2. Naudojantis sudaryta duomenų baze, nustatyti svarbiausius rodiklius skirtingiems AT paskirties keitimo scenarijų atvejams.

3. Apskaičiuoti apleistų teritorijų kiekybinius parametrus taikant daugiarodiklius sprendimų prièmimo metodus (DSPM). Remiantis šiais skaičiavimais, sudaryti apleistų teritorijų paskirties keitimo igyvendinimo scenarijus.

4. Sudarytus apleistų teritorijų scenarijus pritaikyti ir patikrinti konkrečiose Vilniaus miesto seniūnijų teritorijose. 



\section{Apleistų teritorijų skirtingose miesto dalyse geostatistinè analizè}

Šiame skyriuje, remiantis geostatistine analize, atlikti 20-ies Vilniaus seniūnijų AT tyrimai. Išnagrinètos Vilniaus miesto BP funkcinès zonos seniūnijose ir AT sklaidos parametrų ryšys su ekonomine aplinka. Dėl urbanistinių panašumų su Vilniumi ir pakankamo pirminių duomenų šaltinių kiekio šiam tyrimui pasirinktas Liverpulio miestas. Atlikta AT rodiklių apžvalga, nustatyta jų koreliacija su AT pasiskirstymu mieste. Ivvertinus AT sklaidą ir prioritetines miesto teritorijas, pritaikyta AT paskirties keitimo igyvendinimo koncepcija Vilniaus miestui.

Šio skyriaus tema publikuoti du straipsniai (Bielinskas, Burinskienė 2014; recenzuojamame tarptautinių konferencijų straipsnių rinkinyje - Bielinskas 2017).

\subsection{Apleistų teritorijų geostatistinès analizès planas ir metodika}

Lietuvoje žalingiausios miesto aplinkoje esančių AT keliamos problemos pasireiškia buvusiuose rajonų centruose, kuriuose sovietinio režimo laikotarpiu klestejo gamybos pramone. Tokios sąlygos vyravo didžiuosiuose Lietuvos 
miestuose, todèl konkretaus tyrimo objektu pasirinktas Vilniaus miestas. Darbe pateikto tyrimo vykdymo procesų schema pateikta 2.1 paveiksle.

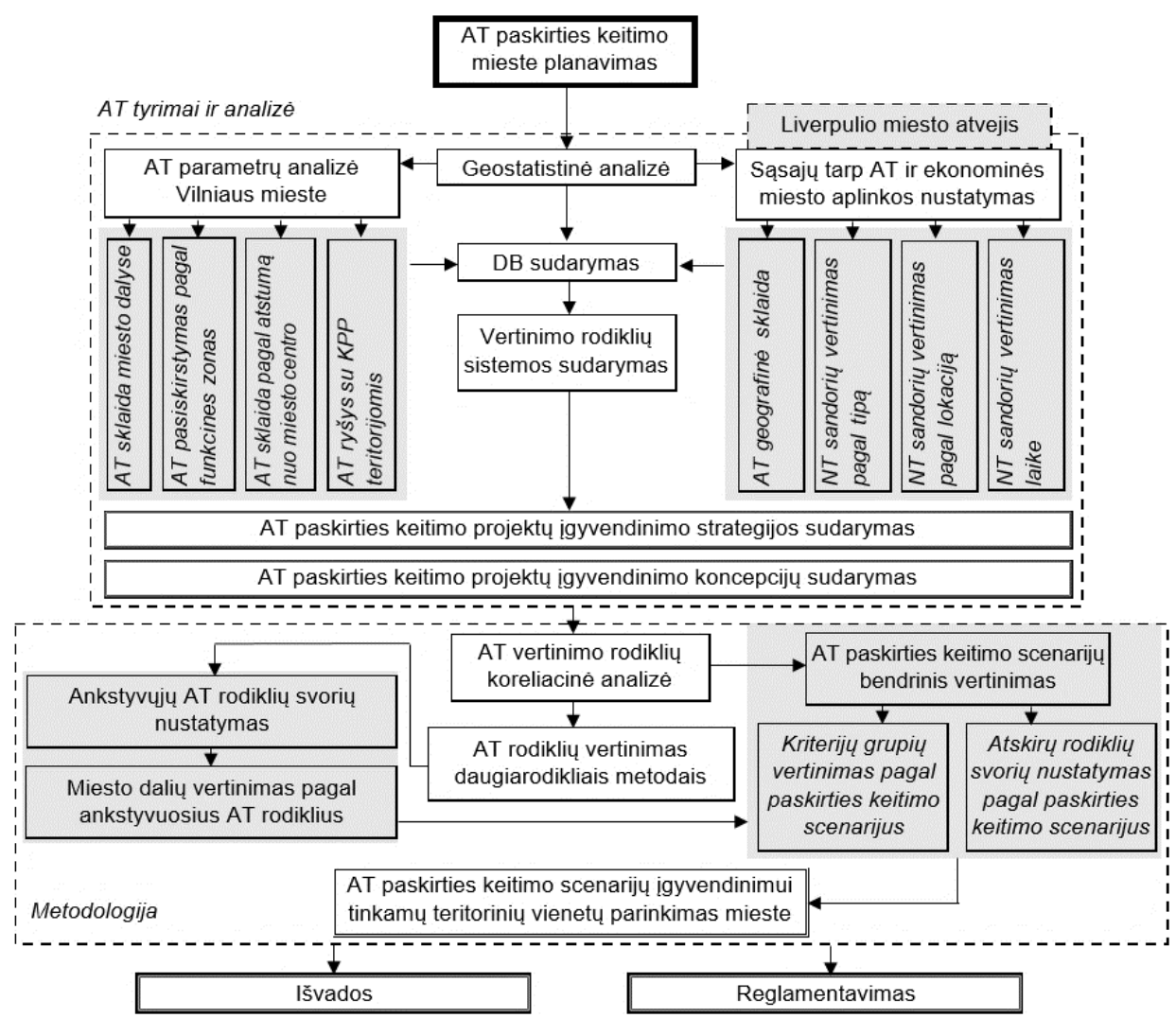

2.1 pav. Tyrimo eksperimentinės dalies algoritmas (sudaryta autoriaus)

Fig. 2.1. The algorithm for the research experimental part (created by author)

Skaičiavimai rodo, kad, priklausomai nuo padeties mieste, gamtinių ir socialinių savybių, vidutiniškai (vertinant imties medianą) vienoje Vilniaus seniūnijoje yra 23 ịvairaus ploto ir inžinerinès bei socialinès infrastruktūros AT (2.5 pav.). Priklausomai nuo seniūnijoje esančios funkcinès sklaidos, AT plotas skiriasi net iki 40 kartų. Mažiausias vidutinis AT plotas nustatytas Fabijoniškių seniūnijoje $(0,04$ ha), didžiausias - Šeškinès (1,58 ha). Didžiausi AT, kaip atskiro teritorinio vieneto, plotai nustatyti pramoninès paskirties seniūnijose (Žemieji Paneriai, Vilkpèdè). Esant didelèms erdvinèms variacijoms, egzistuoja dvi AT vertinimo ir sutvarkymo problemos: globalinè (kai reikia sudaryti prioritetines 
miesto zonas ir jose esančių AT paskirties keitimo planą, kuriose AT sutvarkymas turi būti prioritetinis) ir lokalinè (kai prieš įgyvendinant AT paskirties keitimą pagal pasirinktą scenarijų, reikia ịvertinti svarbiausius šio proceso rodiklius). Kadangi šios dvi problemos viena su kita tiesiogiai susijusios, jos turi būti sprendžiamos įtraukiant papildomąsias analizes. Tyrimai atlikti dviem etapais.

Pagal pirmaji etapą atlikta išsami AT geostatistinè analizè įvairiais aspektais Vilniaus ir Liverpulio (Didžioji Britanija) miestuose. Šiame etape įvertinta 20-ies Vilniaus miesto seniūnijų AT kiekis, išnagrinètas AT erdvinis pasiskirstymas pagal mieste esančias funkcines zonas $F$ (vadovaujantis Vilniaus miesto BP). AT atstumo nuo miesto centro analizè laikoma kaip papildomoji analizès dalis.

Analizė parodè, kad Vilniaus miesto savivaldybès nustatytos koncentruoto plètros potencialo (KPP) zonos neatspindi realios AT keliamus pavojus Vilniaus mieste. Ši analizė atskleidžia, kuriose Vilniaus miesto seniūnijose reikia atkreipti planuotojų dėmesị $i$ esamus ir būsimus statybos ir teritorijų pertvarkymo procesus, atsižvelgiant ị jose esančias AT apimtis.

Atlikus pirmojo etapo tyrimus ir naudojant tyrimuose gautus duomenis, sudaryta DB, apibūdinanti Vilniaus miesto aplinkos parametrus. Apibendrinus pirmojo etapo tyrimų rezultatus, parengta hierarchinė AT vertinimo rodiklių sistema, AT paskirties keitimo projektų igyvendinimo strategija ir atskiros jos koncepcijos.

Antrajame etape, remiantis užsienio mokslinèje literatūroje taikoma praktika (Erener et al. 2016), atlikti AT tyrimai taikant DSPM. Tyrimo metu pastebèta, kad ankstyvujų rodiklių svoriai kinta priklausomai nuo pasirinkto paskirties keitimo scenarijaus ir geografinès padèties. Atlikus antrojo etapo tyrimus, nustatyti skirtingų rodiklių grupių (ir kiekvieno rodiklio atskirai) svoriai pagal pasirinktą scenarijaus atveji, nustatytos tinkamiausios miesto seniūnijos paskirties keitimo atvejams arba jų deriniams.

Siekiant gauti tikslius rezultatus, rodiklių reikšmių apdorojimo erdvejje metu taikyti GIS metodai. Jais remiantis ir taikant DSPM, atliktas geokodavimas ir vertinimas. Tai dažnas būdas mokslinèje literatūroje apdoroti ir vertinti geoerdvinius duomenis (Lwin et al. 2012; Marinescu, Avran 2011).

Surinkti, skaitmeninti ir susisteminti duomenys analizuoti taikant geostatistinès analizės principus, tokius kaip erdvinis duomenų siejimas, jungimas (Benkirane 2016), erdvinè sankirta ir kt. Taikant šiuos metodus, pavyzdžiui, sujungus tris skirtingus erdvinius duomenis erdvèje, bus gautos net 6 skirtingos reikšmès, turinčios bendrus visus šiuos erdvinius komponentus vienijančius parametrus (2.2 pav.) su unikaliomis geografinèmis koordinatemis. Še metodai ir jų kombinacijos mokslinëje literatüroje plačiai taikomos nagrinejjant socialinius ir ekonominius reiškinius (Wang 2006). Tokių metodų ir statistinių skaičiavimų sintezė atlikta naudojant GIS ArcMap 10 ir MS Excel programinę ịrangą. 


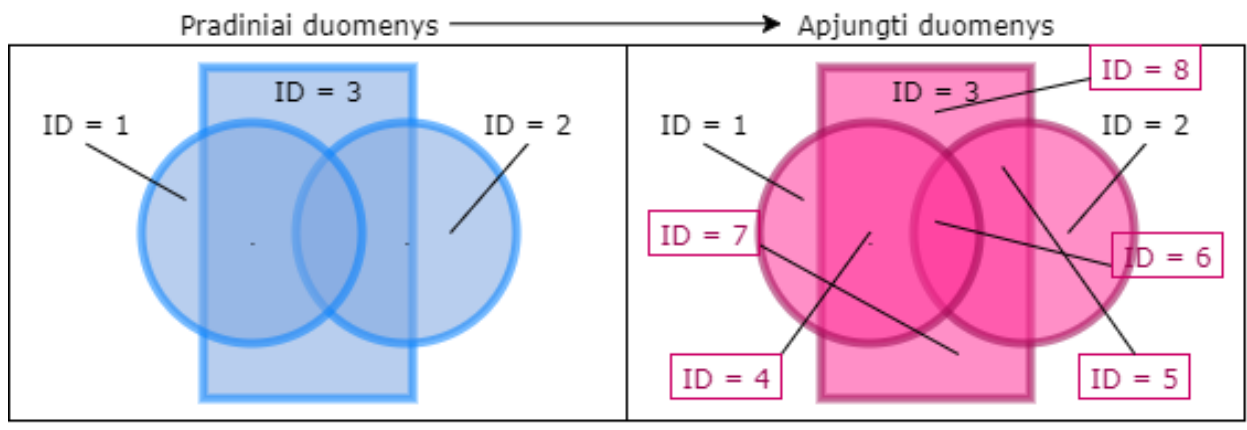

2.2 pav. Erdvinio duomenų jungimo taikant geografines informacines sistemas esminè schema (sudaryta autoriaus)

Fig. 2.2. A pricipal scheme of Spatial Join in Geographical Information System (created by author)

Susisteminti erdviniai duomenys miesto aplinkoje pasiskirstę netolygiai. Pavyzdžiui, jeigu atskiri erdviniai komponentai išsidèstę santykinai dideliu atstumu vienas nuo kito, atliekant erdvinę analizę ir siekiant hipotetiškai nustatyti tarpines reikšmes aplinkoje, atliekama erdvinių duomenų interpoliacija. Praktikoje socialiniams, urbanistiniams ir ekonominiams uždaviniams spręsti dažniausiai taikomas atvirkštinio atstumo svèrimo (angl. Inverse Distance Weighted, toliau - IDW) metodas (2.3 pav.).

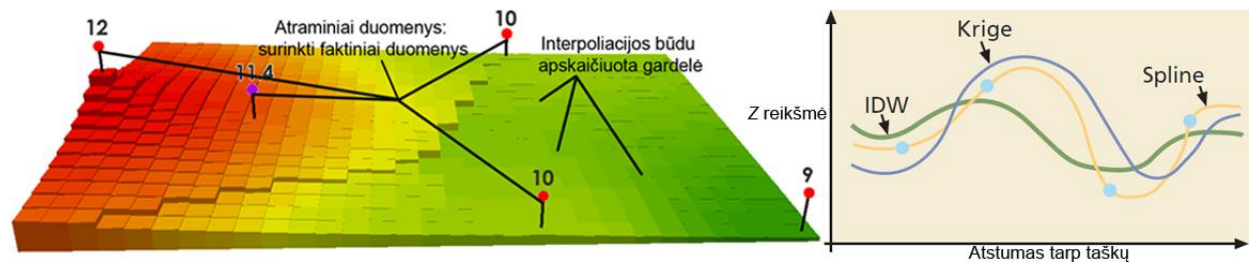

2.3 pav. Atvirkštinio atstumo vertinimo interpoliacijos taikymo pricipai: a) erdvejje; b) plokštumoje (sudaryta autoriaus)

Fig. 2.3. The principles of Inverse Distance Weighted interpolation: a) in a space; b) in projection (created by author)

Šio interpoliacijos metodo esmè - arčiau esantys erdviniai komponentai laikomi svarbesniais (turinčiais didesnị svorị), negu išsidèstę toliau nuo nagrinèjamojo taško (GIS Resources 2014). Interpoliacijos rezultatas yra rastrinè duomenų struktūra. Ši duomenų struktūra išsiskiria tuo, kad kiekvienas erdvès taškas igyja unikalią interpoliacijos būdu apskaičiuotą rodiklio reikšmę. Dèl šios priežasties 
interpoliacijos būdu gautus naujus rezultatus lengva atvaizduoti žemėlapyje ir nagrinèti BP bei kitais strateginio planavimo lygmenimis.

Schemoje nurodyta $Z$ reikšmè išreiškia skaliarinę gardelès reikšmę (ArcGIS Pro 2016) ir apskaičiuojama pagal (2.1) formulę.

$$
z_{j}=\frac{\sum_{i} \frac{z_{i}}{d_{i j}^{n}}}{\sum_{i} \frac{1}{d_{i j}^{n}}},
$$

čia $z_{j}-j$-oji nežinoma reikšmè, kurią bandoma apskaičiuoti; $z_{i}-$ žinomo duomenų taško, pagal kurị interpoliuojama, reikšmé; $d_{i j}$ - atstumas iki žinomo duomenų taško; $n$ - pasirinktas atstumo eksponentès dydis (kontroliuoja aplinkinių duomenų taškų stiprumą, pasirinkta numatytoji reikšmè 2).

2.3 paveiksle pateiktoje metodo grafinejje interpretacijoje matyti, kad, lyginant su kitais erdvinių duomenų interpoliacijos metodais, IDW būdinga mažiausia standartinè deviacija, pereinant nuo vieno erdvinio komponento prie kito. Dèl šios priežasties kraštutinès faktinès reikšmès ignoruojamos, išsprendžiama duomenu perpildymo (angl. overfitting) problema, kai nedidelis duomenų poaibis gali iškreipti visos duomenų imties rezultatus.

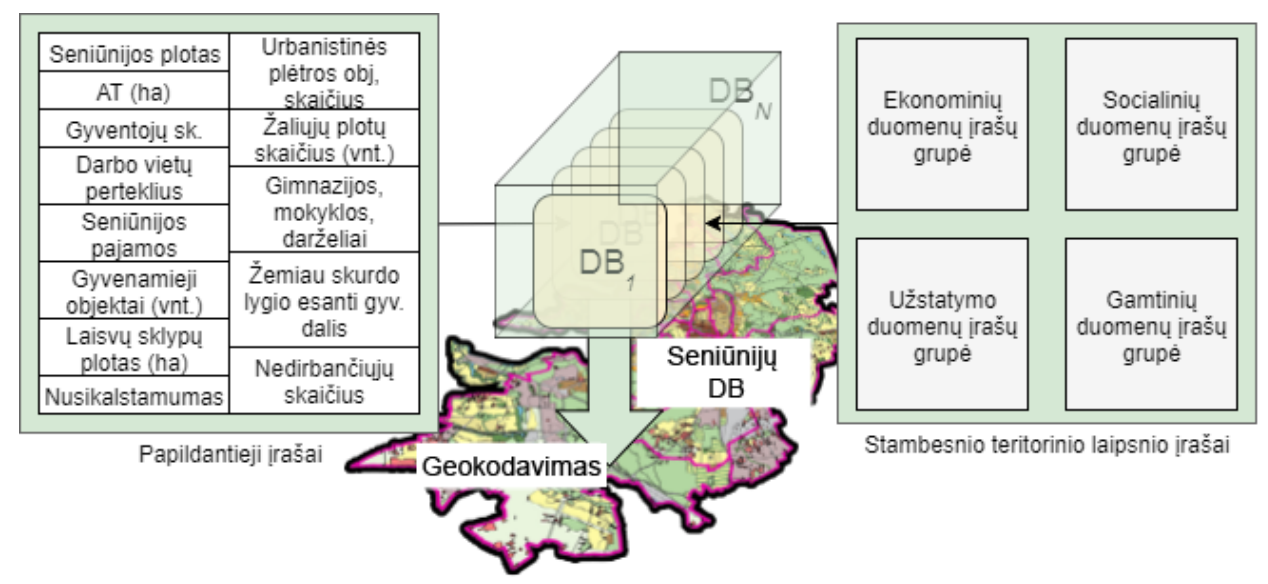

2.4 pav. Geografinių duomenų bazès sudarymo schema (sudaryta autoriaus) Fig. 2.4. A scheme for building-up a geographical database (created by author)

Prieš atliekant AT tyrimus, atliktas DB struktūrizavimas taikant didžiujų duomenų (angl. Big Data) metodus - duomenų agregacija, reprezentatyvios imties 
sumažintas modelis (angl. data sampling) ir kt., ịvertinant Vilniaus miesto teritorinị seniūnijų suskirstymą ir suformuotus surinktus duomenų rinkinius (2.4 pav.). Žaliavinę medžiagą (angl. raw data) sudaro stambesnio teritorinio laipsnio ir papildomieji ịrašai. Pirmieji apima bendrines Vilniaus miesto seniūnijų savybes, pvz., ES investicijos, darbo vietų skaičius, vidutinis pastatų amžius, kietujų dalelių $\left(\mathrm{NO}_{2}\right)$ tarša ir kt. Šie įrašai suklasifikuoti ị stambesnes ekonominių, socialinių, užstatymo ir gamtinių duomenų grupes. Papildomieji ịrašai apibūdina smulkesnių teritorinių vienetų, kurie taikyti naujiems dydžiams išvesti, parametrus. Sudarytos DB ịrašams taikyta geokodacija, leidžianti visus duomenis atvaizduoti žemėlapiuose ir nagrinèti erdvèje taikant 2.1 poskyryje nurodytus metodus.

Toliau iš šių geografiškai koduotų teritorijų išvesti ankstyvieji AT vertinimo rodikliai. Iš viso, taikant aptartas priemones, geografiškai koduota visų 200 Vilniaus miesto seniūnijų 860 ịrašų.

\subsection{Apleistų teritorijų kiekis ir pasiskirstymas Vilniuje}

Vilniaus miesto iki $2015 \mathrm{~m}$. BP AT paskirties keitimo potencialas išreiškiamas saugios socialinès aplinkos gerinimu ir ekonominès plètros kontekstu. Pirmuoju atveju numatyta skatinti pramonès teritorijų paskirties keitimą ir šiose teritorijose esančios infrastruktūros modernizavimą. Antruoju atveju pagal miesto ekonominès plètros viziją skatintas tolygus bendro ūkio paskirties keitimas, kad būtų pritrauktas smulkusis ir vidutinis verslas. Taip pat pažymima, kad tuometinè urbanizacijos plètra priemiesčio šiaurès vakarų sektoriuje bei miesto darbo vietų ir paslaugu išdèstymo netolygumai diktuoja kurti periferini daugiafunkcị kompleksą, vienodai tenkinantị miesto ir priemiesčio gyventojų poreikis. Sudaryti AT žemèlapiai parodè, kad periferinėse miesto dalyse šiaurès vakarų ir šiaurès rytų kryptimis išdèstę didieji AT arealai.

Atlikus Vilniaus miesto esamos būklès vertinimą ir susiejus AT geoerdvinius duomenis su TPSIS, nustatyta, kad AT mastas (2.5, 2.6 pav.) vizualiai yra didesnis, nei deklaruojama BP sprendiniuose. Atliktas AT nustatymas Vilniaus mieste taikant fizinę vietovių fotofiksaciją ir momentini jos vertinimą bei naudojant didelès raiškos $(1,0 \times 1,0 \mathrm{~m})$ aerofotonuotraukas naudojant GIS programinę ịrangą. Tai plačiai praktikoje pasiteisinęs būdas nustatyti karštąsias miesto zonas pagal skirtingus socialinius, ekonominius ir kitus erdvejje apibrežiamus parametrus (Garcia-Palomares et al. 2016). Mūsų atveju aerofotonuotraukos padengia visą Vilniaus miesto teritoriją ir leidžia nustatyti iqvairių paskirčiu ir tipų teritorijas, jų ribas, kiekybines ir kokybines savybes (Chrysochoou 2012). Susiejus TPSIS (2014) ir GIS centro viešinamų duomenų rinkinius su sudarytais ir susistemintais trečiųjų šalių duomenimis, paaiškejjo, kad AT Vilniuje yra beveik 1200 vnt. Sujungus minètuosius duomenų rinkinius su 
nustatytomis AT, bendras AT skaičius padidejo $12 \%$. Tai atskiri 0,92 ha (vertinant imties medianą) vidutinio ploto žemès sklypai (2.5 pav.).

Iš viso šie plotai užima 1090 ha, t. y. 2,7\% visos miesto teritorijos, ir šis dydis kinta. Tik apie $17 \%$ viso AT ploto užfiksuota urbanizuotose miesto zonose.
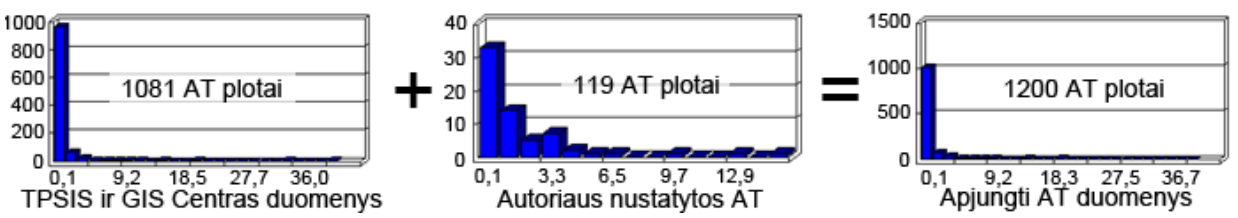

2.5. pav. Apleistų teritorijų kiekio statistinis pasiskirstymas prieš sujungiant duomenis ir juos sujungus (sudaryta autoriaus)

Fig. 2.5. The Statistical distribution of brownfields before and after spatial join (created by author)

Kita dalis - dykrose, atvirose erdvėse, kuriose vyrauja senų ir nebenaudojamų pastatų likučiai, nefunkcionuojančios viešosios erdvès, socialinès dezorganizacijos atstovų aktyvumo zonos ir kiti žalingi aplinkai komponentai (2.1 lentelè).

2.1 lentelè. Statistiniai ir geografiniai apleistų teritorijų parametrai Vilniaus mieste (sudaryta autoriaus)

Table 2.1. Statistical and geographical parameters for brownfields in Vilnius city (created by author)

\begin{tabular}{|c|c|c|c|c|c|c|c|}
\hline \multicolumn{5}{|c|}{ Ploto parametras $A$, ha } & \multirow{2}{*}{$\begin{array}{c}\text { Pastatu } \\
\text { kiekis, vnt. }\end{array}$} & $\begin{array}{c}\text { AT } \\
\text { skaičius, } \\
\text { vnt. }\end{array}$ & Teritorijų tipas \\
\hline$A_{\max }$ & $\bar{A}$ & $A_{\text {med. }}$ & $S$ & Iš viso, ha & & & \\
\hline 37,3 & 1,65 & 0,5 & 3,9 & 185,7 & 93 & 151 & Urbanizuotos teritorijos \\
\hline 37,3 & 0,88 & 0,3 & 2,32 & 904,2 & 9 & 1049 & Neurbanizuotos teritorijos \\
\hline 37,3 & 0,9 & 0,3 & 2,3 & 1089,9 & 102 & 1147 & Sujungta erdvinè AT DB \\
\hline
\end{tabular}

Erdviné analizé parodè, kad AT sudaro arealus. Pagal taikytą atstumo vertinimo dydį (kuo šis dydis mažesnis, tuo arealai yra smulkesni ir gali būti detaliau analizuojami vietovès lygmeniu ir atvirkščiai) sudaro du didžiuosius (2.6 pav.) ir penkis mažuosius (2.7 pav.) arealus pagal AT skaičių. Didžiuosius AT arealus patogu nagrinèti pagal Vilniaus miesto BP reglamentuotas kvartalų ( $\check{S} \mathrm{~V}$ - šiaurès vakarų, ŠR - šiaurès rytų, PV - pietvakarių ir PR - pietryčių krypčių) ribas. Atlikti skaičiavimai parode, kad Vilniaus mieste vyrauja ŠV ir PR AT arealai, kuriuose susitelkę apytikriai $75 \%$ visų AT. Didžioji dalis šių teritorijų priskiriama periferinei 
miesto daliai. Rengiant Vilniaus miesto BP, iki $2005 \mathrm{~m}$. buvo numatoma urbanizacinè plètra ị ŠV sektorių. Tačiau gyvenamojo fondo, darbo vietų ir paslaugų išsidèstymo netolygumai sukuria prielaidas kurti periferinį daugiafunkcị kompleksą, vienodai aptarnaujantị arti miesto periferinès dalies esančių teritorinių bendruomenių centrus ir priemiesčio gyventojus. Tokiu būdu daugiacentré miesto struktūra būtų tinkama vykdyti taikant AT paskirties keitimą periferinèje miesto dalyje.

ŠV ir PV arealų zonose esamas rekreacinès ir turizmo infrastruktūros vystymas keičiant AT paskirtị lemtų priemiesčių ekonomikos struktūros pokyčius. Rengiant Vilniaus miesto BP, iki $2005 \mathrm{~m}$. buvo planuojama, kad žaliojo žiedo urbanizacijos lygis per ateinančius 10 metų didès: maždaug $25 \%$ gyventojų turès būstus šiose zonose. Šiuo atžvilgiu mažo užstatymo gyvenamujų AT paskirties keitimas būtų tinkamas planavimo sprendimas išsaugoti gamtinès aplinkos dominavimą vietoj laisvosios žemès, kurioje naujos inžinerinès infrastruktūros diegimas miesto gyventojams arba naujo NT pirkejjams atsieitų papildomų kaštų.

Sudarytuose žemėlapiuose (2.7 pav.), kuriuose pritaikyta mažesnė atstumo vertinimo reikšmé, matyti, kad AT pasiskirstymas pagal skaičių sudaro penkis smulkesnius arealus, savo geografine padètimi vienodus su Vilniaus mieste šiuo metu vykdomų gyvenamojo būsto statybų vietomis. İvertinant tai, kad tarp šių reiškinių yra 3-4 metų laiko tarpas, galima teigti, kad NT plètotojai ịvertina laisvosios ir apleistosios žemès neišnaudotą potencialą pagal ekonomini požiūrị ilgalaikèje perspektyvoje. Vilniaus mieste šie procesai ypač išryškèję Pilaitès, Pašilaičių, Vilkpèdès ir Pavilnio seniūnijose.

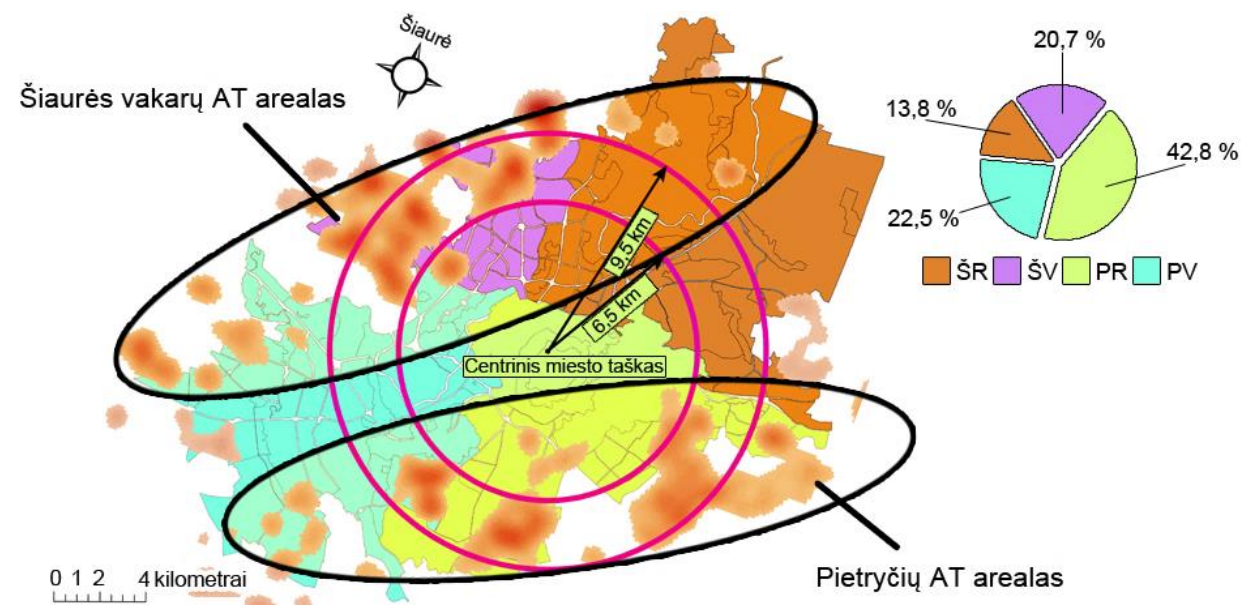

2.6 pav. Apleistų teritorijų arealai pagal skaičių Vilniaus miesto pietvakarių, pietryčių, šiaurès rytų ir šiaurès vakarų zonose (sudaryta autoriaus)

Fig. 2.6. The areas of brownfields according to the number in the zones of South West, South East, North East and North West in of Vilnius city (created by author) 
AT pasiskirstymą pagal užimamą plotą rodo seni ir jau dabar nebenaudojami gamyklų pastatai, inžinerinių arba nebaigtų statyti statinių teritorijos su joms priklausančiomis prieigomis (pvz., nebaigto statyti nacionalinio stadiono, apgriuvusių senų pastatų Šeškinès sen. teritorijos ir kt.).

Remiantis skaičiavimais, pastaraisiais metais naudojantis apleistomis Vilniaus miesto teritorijomis, igyvendinti 230 NT projektai. Iš jų 85 vnt. (t. y. $37 \%$ ) yra gyvenamojo būsto statybos, 10 vnt. (t. y. 4,3\%) - infrastruktūros objektų statybos, 41 vnt. (t. y. 17,8\%) - komercinio NT statybos, 70 vnt. - renovuojamuju pastatu (t. y. 30,4 \%), 23 vnt. (t. y. $10 \%$ ) - visuomeninès paskirties objektų statybos, vienas parko (Vilniaus japoniškujų sodų) projektas.

Pagal AT naudojimo atvejų analizès rezultatus nustatyta, kad centrinèje miesto dalyje vis didesniais tempais vystomos mišrios paskirties teritorijos, kai anksčiau dominavo komercinio NT vystymo projektai. Miesto periferinejje dalyje, kur gyventojų tankis mažiausias, o laisvosios žemès plotų ịsisavinimo kaina, lyginant su centrinès miesto dalies kaina, smarkiai žemesnè, aktyvèja vidutinio ir aukšto užstatymo tankio gyvenamujų būstų statybų projektai.

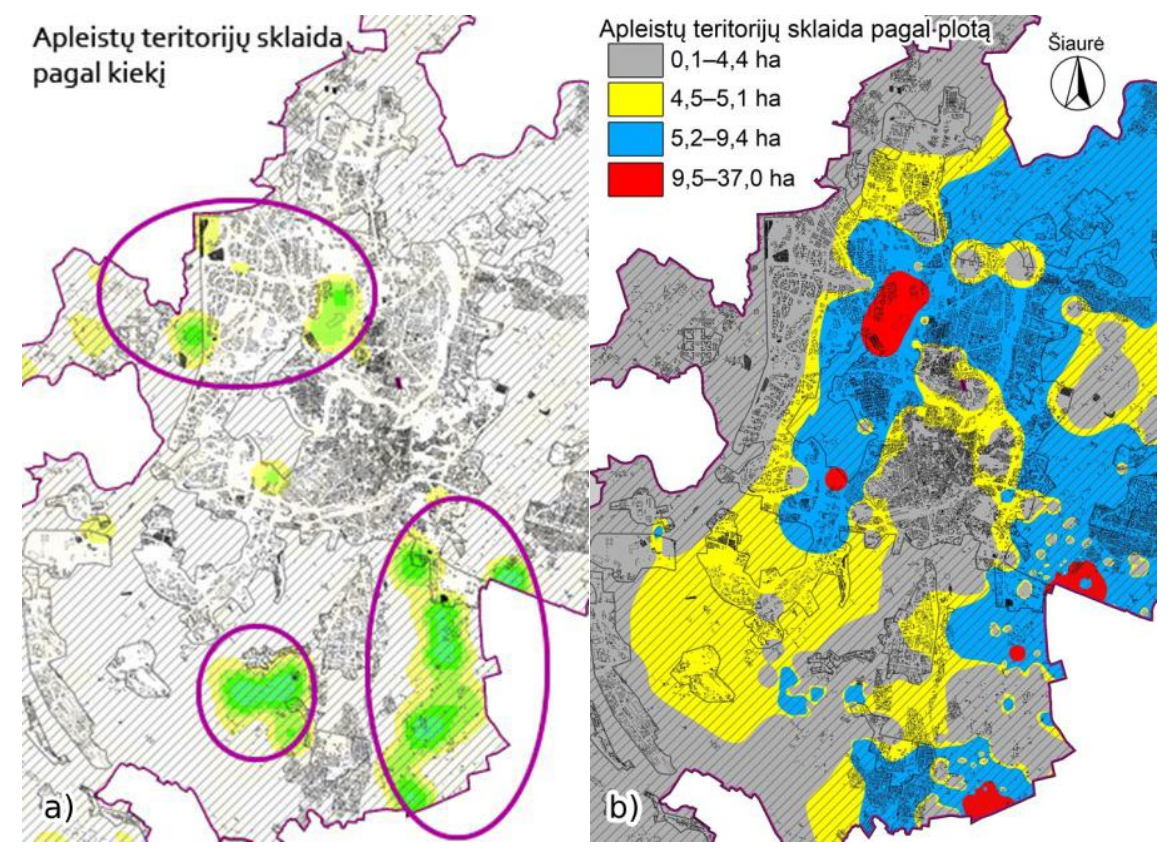

2.7 pav. Apleistų teritorijų Vilniaus mieste erdvinis vertinimas: a) pagal kiekị; b) pagal vyraujančio vidutinio apleistos teritorijos plotą (sudaryta autoriaus)

Fig. 2.7. The spatial evaluation of brownfields in Vilnius city taking into account parameters for: a) quantity; b) the prevailing average area for the brownfields (created by author) 
AT daro įtaką ne tik fizinei aplinkai, bet ir socialiniam ir ekonominiam miesto mikroklimatui plačiaja prasme: ribotos investuotojų pritraukimo galimybės, NT vertès sumažejimas ne tik AT, bet ir šalia jų. AT nustatymas vietovejje yra svarbiausia priemonè teritorijų planavimui ir rinkodaros aktyvumui palaikyti.

Iš 2.8 paveikslo matyti, kad Vilniaus miesto seniūnijose AT yra pasiskirsčiusios netolygiai. Pirmasis mažiausias klasteris jungia dvi seniūnijas, kurios viena nuo kitos morfologine struktūra yra skirtingos, tačiau joms būdingas didelis gyventojų tankis. Šiose seniūnijose AT keliami pavojai yra minimalūs. Kituose dviejuose klasteriuose fiksuojama apie $90 \%$ visų Vilniaus mieste esančių AT. Didžioji jų dalis yra senuosiuose (sovietinio režimo metais) urbanizuotuose miesto rajonuose.

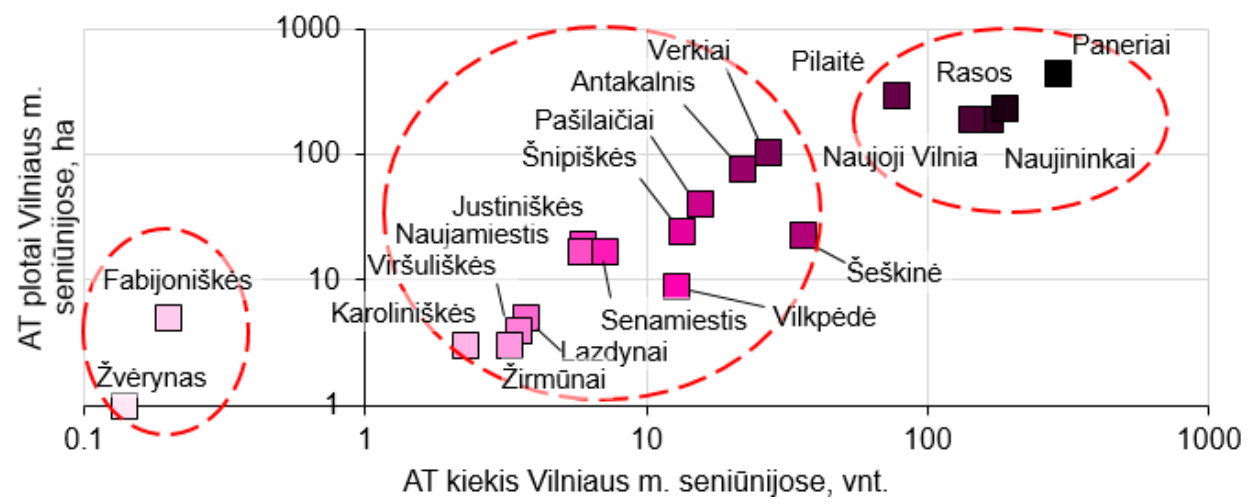

2.8 pav. Seniūnijų pasiskirstymas klasteriais pagal apleistų teritorijų skaičiaus parametrus (sudaryta autoriaus)

Fig. 2.8. The Distribution of neighbourhoods by clusters according to the parameters for the assigned amount of brownfields (created by author)

Tyrimas parodè, kad AT aplinkoje yra 93 pastatai. Tai anksčiau eksploatuotos gamyklos su priestatais, nebaigti statyti inžineriniai statiniai, anksčiau apgyvendinti ne tokiais pasiturinčiais žmonèmis būstai.

Apibendrinus gautus rezultatus, galima teigti, kad AT Vilniaus mieste pasiskirsčiusios pagal tam tikras grupes, kurias galima analizuoti pereinant iš BP teritorinio lygmens ị vietovès lygmenį, planuoti ir pertvarkyti AT teritorijas. Gauti arealai parodo AT grupes, kurioms būdingos tokios pačios ekonominès, urbanistinès, gamtinès arba socialinès aplinkos savybès.

Tai, kad AT yra problema, aprašyta dar $2014 \mathrm{~m}$. rengiant 2012-2020 m. Vilniaus miesto integruotujų teritorijų plètros programos projektą, kur AT problematika ivertinta kaip Vilniaus urbanistinio augimo problema: apleistos, neužstatytos teritorijos miesto centre, nesutvarkytos viešosios erdvès, tinkamai 
neišnaudotos kultūros paveldo vertybès, taip pat ịsišaknijęs aktyvios, sveikos gyvensenos infrastruktūros trūkumas. (Vilniaus miesto savivaldybès taryba 2014).

Toliau darbe Vilniaus miesto seniūnijos vertinamos ir nagrinejjamos kaip imtis bei koduojamos 2.2 lentelèje nurodyta tvarka.

2.2 lentelè. Vilniaus miesto seniūnijų žymenys darbo tyrimuose (sudaryta autoriaus) Table 2.2. Marks of neighbourhoods in the research provided in the thesis (created by author)

\begin{tabular}{|l|l|}
\hline Seniūnijos žymuo & Seniūnija \\
\hline$D_{1}$ & Rasos \\
\hline$D_{2}$ & Šeškinè \\
\hline$D_{3}$ & Naujininkai \\
\hline$D_{4}$ & Pilaitė \\
\hline$D_{5}$ & Pašilaičiai \\
\hline$D_{6}$ & Šnipiškès \\
\hline$D_{7}$ & Naujoji Vilnia \\
\hline$D_{8}$ & Paneriai \\
\hline$D_{9}$ & Justiniškès \\
\hline$D_{10}$ & Viršuliškès \\
\hline$D_{11}$ & Vilkpèdè \\
\hline$D_{12}$ & Naujamiestis \\
\hline$D_{13}$ & Verkiai \\
\hline$D_{14}$ & Karoliniškès \\
\hline$D_{15}$ & Žirmūnai \\
\hline$D_{16}$ & Lazdynai \\
\hline$D_{17}$ & Antakalnis \\
\hline$D_{18}$ & Fabijoniškès \\
\hline$D_{19}$ & Žvėrynas \\
\hline$D_{20}$ & Senamiestis \\
\hline & \\
\hline
\end{tabular}

Funkcinės savybės vertintos pagal Vilniaus miesto BP iki 2015 metų pateiktą teritorijų funkcijų sąrašą. Vilniaus miesto seniūnijoms $D_{i}$ būdingas skirtingas funkcinių savybių pasiskirstymas (2.9 pav.).

Toliau darbe nagrinèjamos Vilniaus BP iki 2015 nustatytos funkcinès zonos, kurių atitikmenys darbe žymimos $F$ :

- $F_{1}$ - infrastruktūros teritorijos;

- $F_{2}$ - terminuotai žemès ūkio ir kitos neužstatytos teritorijos;

- $F_{3}$ - verslo, gamybos ir pramonès teritorijos;

- $F_{4}$ - mažo užstatymo intensyvumo gyvenamosios teritorijos;

- $F_{5}$-visuomenès poreikius atitinkančios, specializuotos ir kompleksų teritorijos; 
- $F_{6}$ - rajonų centrai ir kitos mišriosios didelio užstatymo intensyvumo teritorijos;

- $\quad F_{7}$ - intensyviam naudojimui įrengiami želdynai;

- $F_{8}-$ visuomenès poreikius atitinkančios teritorijos, specializuotos ir komp-leksų teritorijos su dideliu želdinių kiekiu;

- $\quad F_{9}$ - miesto centras, svarbiausi lokalūs centrai;

- $F_{10}$ - ekstensyviam naud. ịrengiami želdynai;

- $F_{11}$ - vidutinio užstatymo intensyvumo gyvenamosios teritorijos;

- $F_{12}$ - Senamiestis;

- $F_{13}$ - intensyvaus užstatymo gyvenamosios teritorijos;

- $F_{14}$ - vandenvietès;

- $F_{15}-$ miškai ir miškingos teritorijos;

- $F_{16}$ - vandenys;

- $F_{17}$ - sodininkų bendrijų teritorijų konversija ị mažo užstymo intensyvumo gyvenamąsias teritorijos;

- $F_{18}-$ sodininkų bendrijos.

Iš anksto numačius tariama, kad Senamiesčio seniūnija $\left(D_{20}\right)$ yra visiškai daugiafunkcès struktūros miesto centrinè dalis. Tolimesniuose skaičiavimuose galioja išimtis: $F_{12}$ teritorijos funkcija ignoruojama dèl to, kad tik Senamiesčio seniūnijoje $\left(D_{20}\right)$ fiksuojamas šis funkcinis tipas.

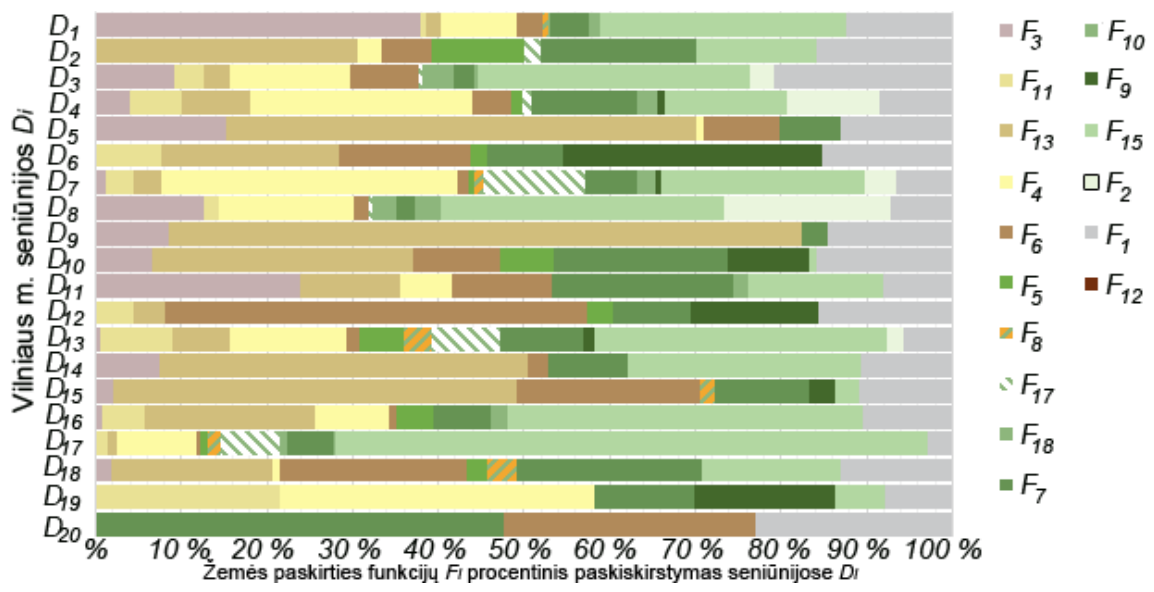

2.9 pav. Funkcijų $F$ pasiskirstymas seniūnijose $D_{i}$ pagal procentus (sudaryta autoriaus)

Fig. 2.9. The percentage share of functions $F$ in neighborhoods of districts $D$ of Vilnius city (created by author)

Rezultatai parodè, kad nagrinètų koreliacijos koeficientų $R$ aibė vienodai pasiskirsčiusi pagal teigiamas ir neigiamas reikšmes. Tarp funkcijų tipų, kurie 
sudaro palankias sąlygas AT daryti įtaką seniūnijoms $D_{1-20}$, labiausiai išsiskiria $F_{3}$ funkcinis tipas. Dažniausiai šios paskirties teritorijoms būdingas monofukciškumas. Tai reiškia, kad, pramonès sektoriui dèl ekonominių ar kitų priežasčių sustabdžius veiklą, kitos paskirties žemès AT paskirties keitimas tampa nemažų finansinių kaštų reikalaujančiu procesu. Dẻl šios priežasties pramoninių teritorijų monofunkcė plètra yra vienas rizikingiausių sprendimų strategiškai planuoti miestą.

Siekiant išsiaiškinti, ar egzistuoja priežastinis ryšys tarp seniūnijose $D_{1-20}$ esančių AT ir funkcinių zonų $F_{1-18}$ apimties, atlikta koreliacinè analizè. Ją taikant nagrinejjamas priežastinis ryšis tarp AT ploto, tenkančio vienam seniūnijos hektarui, ir funkcinių zonų plotų, išreikštas procentais (2.9 pav.). Šios analizès grafinè interpretacija su apskaičiuotais koreliacijos koeficientais $R$ pateikta 2.10 paveiksle.

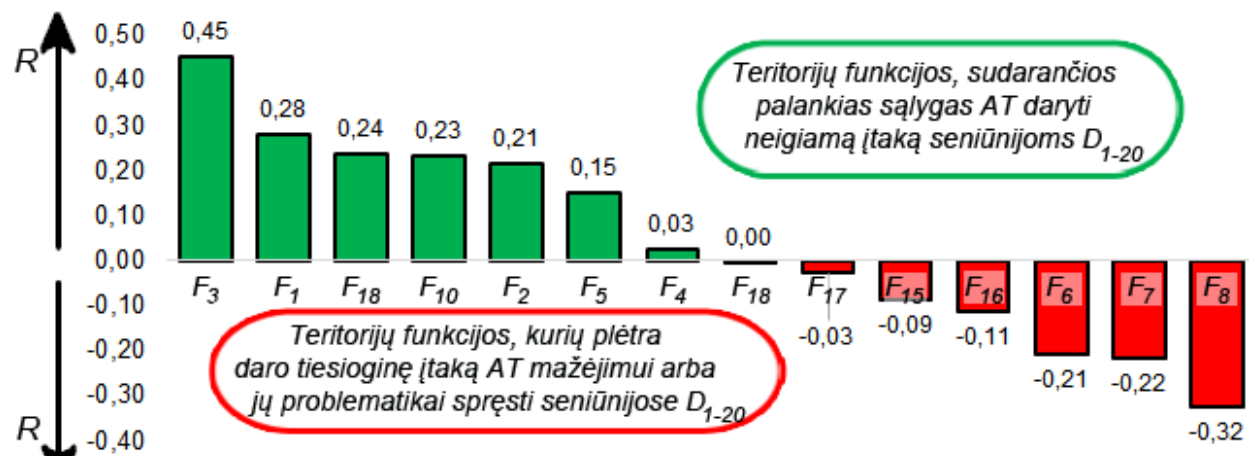

Apleistụ teritoriju galimos žemès paskirties funkcijos

2.10 pav. Apleistų teritorijų ir funkcinių zonų $F_{1-18}$ koreliacinès analizès rezultatų grafinè interpretacija $D_{1-20}$ seniūnijoms (sudaryta autoriaus)

Fig. 2.10. The graphical interpretation of the results of correlation analysis in brownfields and functional $F_{1-18}$ zones in neighbourhoods $D_{1-20}$ of Vilnius city (created by author)

Tarp funkcijų tipų, kurių plètra daro tiesioginę ịtaką AT mažejimui arba labiausiai prisideda prie jų problematikos sumažinimo, ryškiausiai išsiskiria $F_{8}$ (visuomenès poreikius atitinkančios teritorijos, specializuotos ir kompleksų teritorijos su dideliu želdinių kiekiu). Tokių teritorijų Vilniaus mieste priskaičiuojama tik 269 ha (t. y. $0,8 \%$ viso Vilniaus miesto ploto), tačiau skaičiavimai parodè, kad toks teritorijos funkcinis tipas yra vienas iš galimų AT paskirties keitimo scenarijų mieste.

Geostatistinè AT analizè atskleidè, kad daugiausia AT susitelkusios $F_{4}, F_{3}$ ir $F_{2}$ (mažo užstatymo gyvenamosios teritorijos; verslo, gamybos ir pramonès teritorijos; laikinos žemès ūkio ir kitos neužstatytos teritorijos) funkcinių tipų teritorijose (2.11 pav.). 


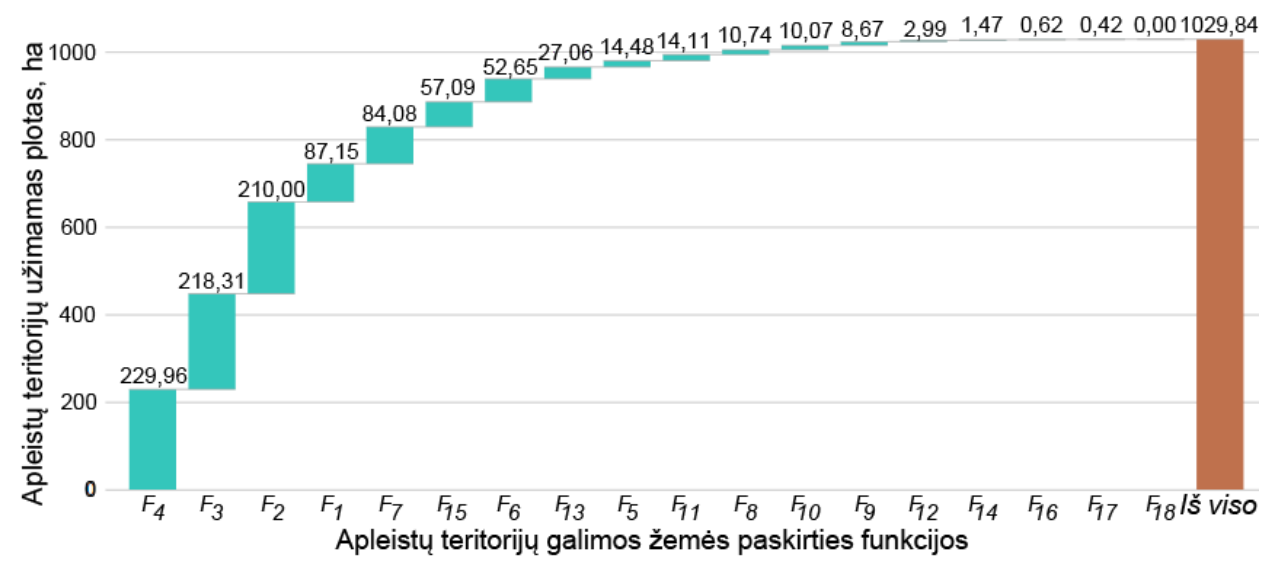

2.11 pav. Apleistų teritorijų pasiskirstymas pagal funkcines Vilniaus miesto zonas (sudaryta autoriaus)

Fig. 2.11. The share of brownfields by the functional areas of Vilnius city (created by author)

Remiantis šios analizès rezultatais, galima teigti, kad seniūnijos, kuriose dominuoja šių funkcinių tipų teritorijos, turètų būti prioritetinès, keičiant AT paskirti strateginiu miesto planavimo lygmeniu. Prioritetinių seniūnijų grupavimas ir klasifikavimas, ịvertinant jose esantị AT plotą ir anksčiau aptartas savybes, pateiktas 2.3 lentelèje.

Naudojantis turimais GIS duomenis, apskaičiuotas AT pasiskirstymas Vilniaus miesto seniūnijoje $D_{1-20}$. Tyrimas leido skirtinguose arealuose išskirti konkrečias miesto seniūnijas, kuriose AT tenkantis kiekis yra didžiausias. Skaičiuota taikant erdvinès sankirtos (2.3 pav.) metodą. Šie skaičiavimai sudaro pagrindą išskirti seniūnijų $D_{1-20}$ grupes pagal jose esančių AT paskirties keitimo prioritetiškumą. Nustatyti AT skaičiai kiekvienai $D_{1-20}$ seniūnijai pateikti 2.3 ir 2.4 lentelèse.

2.3 lentelè. Apleistų teritorijų skaičius seniūnijose $D_{1-10}$ (sudaryta autoriaus)

Table 2.3. The number of brownfields in neighbourhoods $D_{1-10}$ (created by author)

\begin{tabular}{|l|c|c|c|c|c|c|c|c|c|c|}
\hline Seniūnija & $D_{1}$ & $D_{2}$ & $D_{3}$ & $D_{4}$ & $D_{5}$ & $D_{6}$ & $D_{7}$ & $D_{8}$ & $D_{9}$ & $D_{10}$ \\
\hline $\begin{array}{l}\text { AT skaičius } \\
\text { Seniūnijos } \\
\text { plotas, ha }\end{array}$ & 232 & 23 & 192 & 292 & 41 & 24 & 192 & 433 & 19 & 4 \\
\hline AT plotas, ha & 188,9 & 36,4 & 167,0 & 77,4 & 15,5 & 13,5 & 143,4 & 293,4 & 6,0 & 3,5 \\
\hline $\begin{array}{l}\text { AT } \mid D_{1-20}, \\
\text { ha/10 000 }\end{array}$ & 827,3 & 793,5 & 538,2 & 532,9 & 475,5 & 430,4 & 372,5 & 346,3 & 302,2 & 136,4 \\
\hline
\end{tabular}


2.4 lentelè. Apleistų teritorijų skaičius Vilniaus seniūnijose $D_{11-20}$

Table 2.4. The number of brownfields in neighbourhoods $D_{11-10}$ (created by author)

\begin{tabular}{|l|c|c|c|c|c|c|c|c|c|c|}
\hline Seniūnija & $D_{11}$ & $D_{12}$ & $D_{13}$ & $D_{14}$ & $D_{15}$ & $D_{16}$ & $D_{17}$ & $D_{18}$ & $D_{19}$ & $D_{20}$ \\
\hline AT skaičius & 9 & 17 & 103 & 3 & 3 & 5 & 76 & 5 & 1 & 17 \\
\hline $\begin{array}{l}\text { Seniūnijos } \\
\text { plotas, ha }\end{array}$ & 1075,2 & 531,1 & 2483,0 & 373,3 & 567,0 & 995,5 & 7707,6 & 369,3 & 262,1 & 399,6 \\
\hline $\begin{array}{l}\text { AT plotas, ha } \\
\begin{array}{l}\text { AT } \mid D_{1-20} \\
\text { ha/10 000 gyv. }\end{array}\end{array} 112,9$ & 5,9 & 27,1 & 2,3 & 3,3 & 3,75 & 22,1 & 0,2 & 0,1 & 7,2 \\
\hline
\end{tabular}

Apskaičiuota, kad vienam seniūnijos hektarui daugiausia AT ploto tenka Rasų (827,3 ha) ir Šeškinès (793,5 ha) seniūnijose. Mažiausiai AT vienam seniūnijos hektarui tenka Lazdynų, Fabijoniškių, Antakalnio, Senamiesčio ir Žvėryno seniūnijose. Analizuojant absoliutujji AT plotą, tenkantị seniūnijai, išsiskiria Panerių seniūnija. Šioje seniūnijoje didžioji AT dalis yra pramoninès paskirties, kurioje trūnija nefunkcionalūs pastatai.

Analizè parodè, kad, atsižvelgiant ì AT sklaidą mieste, tikslingiausiai suplanuota Pilaitès pr., Naujamiesčio ir Šnipiškių seniūnijų plètra. İ Naujosios Vilnios, Paupio ir Saulètekio AT pertvarkymą dèmesio nekreipiama. Kitose seniūnijose daugiau dèmesio skiriama naujoms žemėms ịsisavinti (pvz., naujoms darbo vietoms kurti), pvz., Žemieji Paneriai, Kirtimai ir kt. Planuojant detalizuotus AT pertvarkymo sprendinius, būtina atskirai analizuoti gyvenamuosius kvartalus. Pavyzdžiui, Perkūnkiemio mikrorajone net 5,18\% plètros užima AT, tačiau pagal BP sprendinius šiose zonose nèra suplanuota žaliụjų viešųjų erdvių bei kitos būtinos gyvenamiesiems kvartalams būdingos viešosios infrastruktūros, kuri sudaro sąlygas kurti papildomas darbo vietas, pramonines zonas ir kt. Vyksta konfliktas tarp faktinès ir planinès teritorijos paskirties. Nedarnios plètros modelio prielaidą patvirtina ir apskaičiuotas koreliacijos koeficientas tarp KPP zonų ir AT apimčių. Šis koeficientas priklauso silpnojo ryšio klasei $(R=0,21)$.

Nors plètra apima AT sutvarkymą, tačiau jos tvarkomos ne pagal darnios plètros principus: nėra žaliujjų erdvių, nesprendžiamos susisiekimo problemos, plečiami didelio užstatymo intensyvumo plotai ir t. t.

Koreliacinès analizès būdu nustatyta, kad yra stiprus ryšys tarp AT skaičiaus ir šių teritorijų atstumo nuo Vilniaus miesto centro (Centrinio pašto pastato Gedimino pr.). Šis ryšys apibrèžtas kaip koreliacijos koeficientas $R$, siejantis šiuos du dydžius. Apskaičiuota koreliacijos koeficiento reikšmė tarp AT skaičiaus ir atstumo iki miesto centro, judant link miesto periferinès dalies iki $6,5 \mathrm{~km}$ ribos, yra 0,93 . Šią kryptị išlaikant nuo $9,5 \mathrm{~km}$ ribos iki tolimiausios miesto 
administracinès ribos krašto, koreliacijos koeficiento reikšmė siekia 0,89 (2.12 pav.).

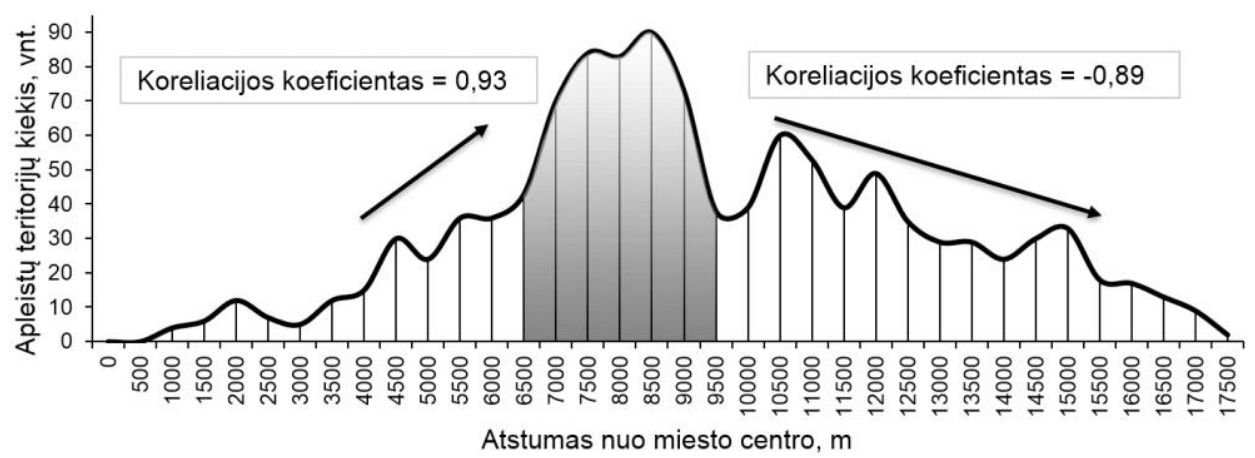

2.12 pav. Apleistų teritorijų skaičiaus pasiskirstymas pagal atstumą iki Vilniaus miesto centro ir koreliacijos koeficientai (sudaryta autoriaus)

Fig. 2.12. The quantitative distribution of brownfields by distance from the centre of Vilnius and correlations coefficients (created by author)

Teigiama koreliacijos koeficiento reikšmè rodo, kad atstumas nuo centrinès miesto dalies daro tiesioginę ịtaką AT apimčiai beveik iki periferinių miesto teritorijų. Tačiau šiam atstumui pasiekus $9,5 \mathrm{~km}$ ribą, miesto centras netenka savo svarbos, ir judant link miesto periferinès dalies (koreliacijos koeficientas igyja neigiamą reikšmę), AT skaičiui ir pasiskirstymui didžiausią ịtaką daro kiti veiksniai (funkcinès zonos, esama inžinerinè infrastruktūra, viešosios erdvès, vyraujanti socialinè aplinka ir kt.).

Rezultatai parodè, kad didžiausias žemès ūkio AT skaičius yra ties Vilniaus miesto administracinių ribų sankirta su periferine miesto zona, šiuo metu nebenaudojamų pramoninių teritorijų ir jų prieigų zonose. Pirmuoju atveju didelę įtaką daro vykstančios manipuliacijos NT, kai įsigyjama pigesnè negu centrinèje miesto dalyje žemė ir laukiama tinkamo momento sudaryti naudingą sandorị bei parduoti ar kitaip disponuoti siekiant asmeninès naudos. Dèl šios priežasties tokios teritorijos tampa neveiksnios. Dèl ilgai derinamų sprendimų savivaldybių istaigose perimti ir naudoti AT pagal miesto reikmèms numatomą paskirti tampa sunkiai ịgyvendinamu uždaviniu (Černiauskas 2014).

Pagal antraji atvejị senos ir nebenaudojamos gamyklos yra dažnas reiškinys Sovietų Sajungos okupuotoms šalimis, kurios susiduria su AT integravimu ị miesto daugiasektorę aplinką. Didžiausia AT atstatymo problema yra vietinio kultūrinio paveldo išstūmimas arba jo suardymas. Su šia problema dažnai susiduria visos Europos šalys (Jackson et al. 2010). 
Geostatistinè analizė parodè, kad 6,5-9,5 km ruože nuo Vilniaus miesto centro yra išsidèstę net $32 \%$ visų mieste esančių AT (444 vnt., 2.13 pav.). Didžioji šių teritorijų dalis (25\%) pagal Vilniaus miesto BP iki $2015 \mathrm{~m}$. priskiriama verslo, gamybos ir pramonès bei infrastruktūros $(14 \%)$ paskirties zonoms. Jose dominuoja posovietiniu laikotarpiu sukurta infrastruktūra: magistraliniai inžineriniai tinklai, gyvenamieji, administraciniai ir visuomeniniai pastatai bei pramonès objektai.

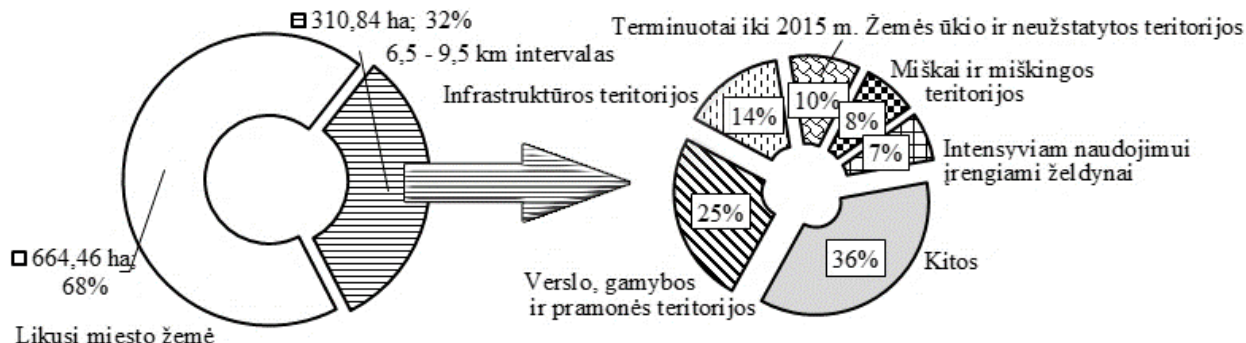

2.13 pav. Ruožo, esančio tarp 6,5 ir 9,5 km nuo Vilniaus miesto centro, nustatyti apleistų teritorijų skaičiai (sudaryta autoriaus)

Fig. 2.13. The calculated numbers of the brownfield strip located at a distance of $6,5-9,5 \mathrm{~km}$ from the centre of Vilnius city (created by author)

Toliau atlikta periferinèje miesto dalyje esančių AT geostatistinè analizè. Periferinè miesto dalis - viena jautriausių miesto plètros zonų. Statistika rodo, kad urbanizacija periferinèse miesto zonose ir aplink jas ịsikūrusiose gyvenvietèse dominuoja AT koncentracijos židiniai (1.11 ir 2.6 pav.). Atsižvelgiant i i šiuos duomenis, AT sklaidos geoerdvinès statistinès analizès rezultatai turi būti vertinami kompleksiškai su likusios miesto teritorijos sprendiniais.

Atliekant šią analizę, perdengus su GIS priemonėmis sudarytu skaitmeniniu miesto modeliu, nagrinèti Vilniaus miesto savivaldybès apibrèžtu ${ }^{3}$ koncentruoto plètros potencialo zonų duomenys (2.14 pav.).

Apskaičiuota, kad periferinè miesto dalis užima 11,2 tūkst. ha, šiame plote yra 295,6 ha AT. Tai sudaro 2,64 \% visos periferinès miesto dalies. Vidutinis vienos AT plotas $-0,54$ ha, tai yra 0,23 ha daugiau negu vidineje miesto dalyje. Šis skirtumas sudaro prielaidą teigti, kad periferinèje miesto dalyje esančios AT ir jų prieigos pasižymi didesniu monofukciškumu nei urbanizuotoje miesto dalyje esančios AT.

\footnotetext{
${ }^{3}$ KPP apibrěžtos Vilniaus miesto savivaldybės administracijai rengiant Naujų transporto rūšių iki 2040 m. SP.
} 


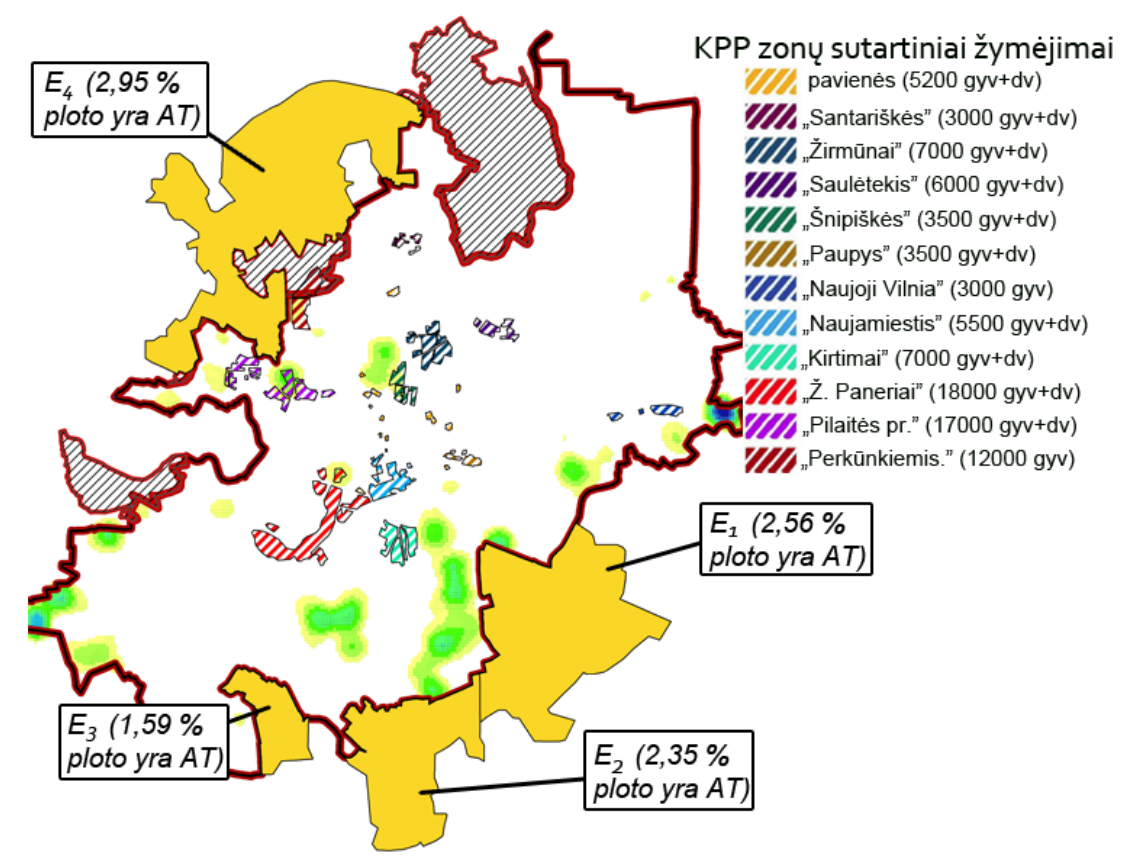

2.14 pav. Periferinėse Vilniaus miesto zonose esančių apleistų teritorijų dalis ir Vilniaus mieste esantys magistraliniai dujotiekio ir elektros tinklai (sudaryta autoriaus)

Fig. 2.14. The share of brownfields in peripheral areas of Vilnius and the main gas pipelines and electricity networks in Vilnius city (created by author)

Pažymėtina tai, kad apibrèžtu KPP zonose, rengiant SP, buvo apskaičiuotas optimistinis naujų gyventojų skaičiaus prieaugis esamomis urbanistinėmis sąlygomis. Privačiam kapitalui ịgyvendinus didžiają dalị numatytų statybos projektų, kai kuriose KPP zonose prasidejo socialinès dezorganizacijos, nelygybės didejjimo reiškiniai, padidèjo viešojo saugumo ir atskirtumo nuo likusio miesto konteksto holistinis pojūtis. Šis reiškinys negali būti techniškai atspindètas BP ir kituose planavimo dokumentuose. Detalūs AT pasiskirstymo periferinėse žemėse $\left(E_{1}, E_{2}, E_{3}\right.$ ir $E_{4}$ ) duomenys pateikti 2.6 lentelèje.

2.14 paveiksle pateiktas esamos situacijos vaizdas patvirtina prielaidą, kad Vilniaus miesto plètros krytis nukreipta ì šiaurès vakarus (didelio užstatymo intensyvumo teritorijos) ir ị pietryčius (pramonès, gamybos, verslo ir rezervinès miesto teritorijos). Šios plètros kryptys sutampa su pagrindiniu magistralinių inžinerinių tinklų trasomis. Tai rodo, kad, planuojant miesto plètros kryptis, iš dalies buvo atsižvelgta ị esamą inžinerinę infrastruktūrą. Dèl to didžiausiais pavojais išlieka aplinkosauginis ir socialinis aspektas, ypač AT arealuose ir jų 
prieigos zonose. Apibendrinta periferinių Vilniaus miesto dalių statistika, atsižvelgiant ị AT apimtis, pateikta 2.5 lentelèje.

2.5 lentelè. Apleistų teritorijų pasiskirstymo periferinėse miesto dalyse statistiniai duomenys (sudaryta autoriaus)

Table 2.5. Statistical data of brownfields in peripheral parts of Vilnius city (created by author)

\begin{tabular}{|c|c|c|c|c|c|}
\hline \multirow{2}{\text{Žymuo}}{} & Plotas & $\%$ & $\begin{array}{c}\text { AT ploto vidurkis } \\
\text { zonoje, ha }\end{array}$ & \multicolumn{2}{|c|}{ AT plotas, ha } \\
\hline$E_{1}$ & 3508 & $31,32 \%$ & 0,44 & 89,77 & $2,56 \%$ \\
\hline$E_{2}$ & 2030,1 & $18,13 \%$ & 0,94 & 47,8 & $2,35 \%$ \\
\hline$E_{3}$ & 659,8 & $5,89 \%$ & 0,42 & 10,47 & $1,59 \%$ \\
\hline$E_{4}$ & 5002,1 & $44,66 \%$ & 0,37 & 147,58 & $2,95 \%$ \\
\hline Iš viso & 11200 & $100 \%$ & 0,54 & 295,62 & $2,64 \%$ \\
\hline
\end{tabular}

Remiantis pateiktais analizès rezultatais, galima teigti, kad daugiausia AT paskirties keitimo kontrolès ir reguliavimo reikalauja šiaurès vakarų ir pietryčių periferinès Vilniaus zonos. Šiose zonose nustatyta 235,35 ha, t. y. net 79,6 \% visų periferinejje Vilniaus miesto dalyje esančių AT. Taigi, planuojant kompaktišką miesto modeli, periferineje Vilniaus miesto dalyje AT paskirties keitimas pirmiausia turi būti vykdomas $E_{1}$ ir $E_{4}$ zonose.

Detalizuojant jau gautus rezultatus, toliau nagrinètas AT pasiskirstymas pagal KPP zonas. KPP - tai zonos, kuriose planuojami didžiausi demografiniai ir statybų apimties pokyčiai iki $2020 \mathrm{~m}$. esant savivaldybès ir privataus verslo kapitalo isitraukimui. KPP pasiskirstymas pateiktas 2.14 paveiksle ir 2.6 lenteleje. KPP praktikoje paskutini kartą buvo vertintos $2011 \mathrm{~m}$. Vilniaus miesto savivaldybès administracijai rengiant naujų transporto rūšių diegimą Vilniaus mieste SP (Vilniaus miesto savivaldybès... 2011).

Atliekant analizę, nustatyta, kad KPP zonų planavimas vykdytas neatsižvelgiant i AT skaičiu seniūnijose ir geografines jų savybes. Apskaičiuota, kad KPP potencialas Vilniaus mieste sudaro 1405,35 ha, t. y. 3,43\% viso miesto ploto. Palyginimui - AT užima 1089,91 ha, t. y. 2,66 \%. KPP zonose AT užima tik 66,28 ha, t. y. $6,31 \%$.

Šis neatitikimas tarp ilgalaikio strateginio planavimo ir AT pasiskirstymo mieste patvirtina iškeltą hipotezę, vykdant strategini miesto planavimą iki šiol nebuvo atsižvelgta į AT geografini pasiskirstymą, galimą pavojų socialinei aplinkai ir jų ekologinị poveikị. Și reiškinị galima paaiškinti tuo, kad dauguma AT miestuose yra išsidėsčiusios izoliuotose arba marginalinèse zonose, kuriose vyrauja socialinė dezorganizacija, anonimiškos ir padidejjusio kriminogeninio aktyvumo erdvès (Bielinskas et al. 2014; Blanco et al. 2009), todèl dauguma plètotojų nèra linkę investuoti ị tokių rizikingų miesto dykrų atgaivinimą. 
2.6 lentelè. Apleistų teritorijų pasiskirstymas koncentruotos plètros potencialo (KPP) zonose (sudaryta autoriaus)

Table 2.6. The distribution of brownfields in the areas of the potential for concentrated development (KPP) (created by author)

\begin{tabular}{|l|c|c|c|c|c|}
\hline KPP zonos & Plotas, ha & AT, ha & $\%$ & Gyv. sk. & $\%$ \\
\hline Pavienès & 53,11 & 2,01 & 3,78 & 3472 & 8,45 \\
\hline Santariškès & 29,6 & 1,25 & 4,22 & 797 & 1,94 \\
\hline Žirmūnai & 111,46 & 2,42 & 2,17 & 3907 & 9,51 \\
\hline Saulètekis & 60,53 & 0,00 & 0,00 & 2000 & 4,87 \\
\hline Šnipiškès & 75,62 & 7,30 & 9,65 & 3418 & 8,32 \\
\hline Paupys & 37,28 & 0,00 & 0,00 & 806 & 1,96 \\
\hline Naujoji Vilnia & 54,72 & 0,00 & 0,00 & 185 & 0,45 \\
\hline Naujamiestis & 124,89 & 7,03 & 5,63 & 9425 & 22,93 \\
\hline Kirtimai & 136,09 & 2,39 & 1,76 & 336 & 0,82 \\
\hline Žemieji Paneriai & 388,59 & 10,18 & 2,62 & 1175 & 2,86 \\
\hline Pilaitės prospektas & 193,14 & 26,43 & 13,68 & 6053 & 14,73 \\
\hline Perkūnkiemis & 140,32 & 7,27 & 5,18 & 9522 & 23,17 \\
\hline \multicolumn{1}{r|r}{ Iš viso } & 1405,35 & 66,28 & 4,06 & 41096 & 100,00 \\
\hline
\end{tabular}

Viena pagrindinių šių problemų priežasčių - trumparegiškas miesto erdvių planavimas, pabrèžiant tik vieną arba kelis kriterijus, dažniausiu atveju ekonominius, kurie nukreipti ị finansinę privataus kapitalo naudą.

Remiantis statistiniais duomenimis, daugiausia gyventojų yra Perkūnkiemio ir Naujamiesčio KPP zonoms (apytikriai 46,1 \% visų KPP zonose esančių gyventojų). Taip pat šiose KPP zonose užfiksuotas vienas didžiausių AT, tenkančių vienam KPP zonos hektarui, skaičius (atitinkamai 5,18 \% ir 5,63 \%). Šnipiškèse ir Pilaitės KPP zonose šis rodmuo didesnis yra didžiausias iš visų apibrèžtu KPP zonų (atitinkamai 9,65\% ir 13,68\%).

Šie duomenys išryškina dvi pagrindines plètros kryptis: 1-oji - miestų plètra nukreipta ị erdves (Naujamiestis, Naujininkai, Šnipiškès), kurioms labiausiai būdingos marginalinès bendruomenès, kur geografinès savybès ir susisiekimas su ekonominėmis miesto zonomis sudaro tvirtą pagrindą NT išliekamajai vertei. Todèl investicijos ị paskirties keitimo ir AT atkūrimo procesus šiose miesto vietose reikalauja santykinai mažesnio pradinio kapitalo ir yra patrauklios privatų kapitalą taikant PPP arba visiškai perleidžiant turtą; 2-oji kryptis - tai tipiška plètros kryptis, kai dèl mažesnių pradinių investicijų, kurias lemia santykinai žema žemès ir kito NT kaina (Perkūnkiemis), yra nukreipiama ị periferinę zoną su mažai išvystyta esama inžinerine ir socialine infrastruktūra dèl komercinès NT naudos. Paprastai tai lemia žemesni gyvenimo kokybès lygi (neišvystyta susisiekimo infrastruktūra, gajos monofunkcès zonos, nėra žaliujų erdvių, nėra 
urboekologinès funkcijos ir kt.), tačiau, tinkamai šiose zonose išnaudojant AT, galima sukurti vietos gyventojų poreikius atitinkantị bendraji gèrị.

Siekiant kompleksiškai vykdyti mieste esančiu AT pertvarkymą remiantis šiomis gairèmis, būtina sudaryti miesto dalių prioritetų tvarką. Remiantis sudaryta prioritetu sistema, sudaromos tinkamos sąlygos rengti AT pertvarkymo strategiją, nustatyti jautriausias miesto zonas igyvendinant miesto plètros sprendinius.

Apibendrinus atliktos geostatistinès analizès rezultatus ir atsižvelgus ị ML bei HL sudarytą AT tipologiją (1.2.1 poskyris), sukurtas prioritetinių seniūnijų sąrašas (2.7 lentelè). Kiekvienai seniūnijai priskirtas vykdyti AT paskirties keitimo procesus pagal svarbą lygis $\operatorname{Pr}$ (Bielinskas et al. 2018). Toks skirstymas sudaro tinkamas sąlygas palyginti skirtingų miesto teritorinių vienetų svarbą vykdyti teritorijų planavimo ir statybos sprendinius pagal strateginius lygmenis naudojant AT laiko atžvilgiu.

Miesto teritorinių vienetų $D_{i}$ prioritetiškumo sistemą sudaro trys klasès (I, II ir III). Aukščiausio prioriteto klasei priklauso Viršuliškių $\left(D_{10}\right)$ ir Šnipiškių $\left(D_{6}\right)$ seniūnijos. Tai vienos tankiausiai apgyvendintų neformalių teritorinių bendruomenių zonos Vilniaus mieste. Todèl AT paskirties keitimas šiose miesto dalyse hipotetiškai gali daryti didžiausią poveikį ten esančių gyventojų poreikiams tenkinti plètojant socialinę ir inžinerinę infrastruktūrą (bendrojo gèrio sukūrimas pakeitus AT paskirtį).

2.7 lentelè. Miesto seniūnijų prioritetiškumo sistema (sudaryta autoriaus)

Table 2.7. The priority system for city (created by author)

\begin{tabular}{|l|l|l|}
\hline Prioritetiškumas, $P r$ & \multicolumn{1}{|c|}{ Seniūnija } & $\begin{array}{c}\text { Apleistų teritorijų užimamas } \\
\text { plotas, ha/10 000 gyv. }\end{array}$ \\
\hline 1 & \multicolumn{1}{|c|}{2} & \multicolumn{3}{c|}{3} \\
\hline 1 & $D_{10}$ & 256,5 \\
\hline 1 & $D_{6}$ & 312,7 \\
\hline 2 & $D_{15}$ & 57,5 \\
\hline 2 & $D_{13}$ & 109,3 \\
\hline 2 & $D_{11}$ & 119,9 \\
\hline 2 & $D_{5}$ & 475,5 \\
\hline 2 & $D_{3}$ & 167,0 \\
\hline 3 & $D_{19}$ & 5,3 \\
\hline 3 & $D_{14}$ & 61,2 \\
\hline 3 & $D_{12}$ & 111,3 \\
\hline 3 & $D_{9}$ & 302,2 \\
\hline 3 & $D_{2}$ & 793,5 \\
\hline 3 & $D_{1}$ & 827,3 \\
\hline 4 & $D_{18}$ & 5,4 \\
\hline 4 & $D_{16}$ & 37,7 \\
\hline
\end{tabular}


2.7 lentelés pabaiga

\begin{tabular}{|l|l|l|}
\hline & \multicolumn{1}{|c|}{2} & \multicolumn{1}{|c|}{3} \\
\hline 4 & $D_{20}$ & 179,4 \\
\hline 4 & $D_{8}$ & 346,3 \\
\hline 4 & $D_{7}$ & 372,5 \\
\hline 4 & $D_{17}$ & 28,7 \\
\hline
\end{tabular}

Pritaikius geostatistinès analizès metodus (2.1 poskyris), nustatyta, kad urbanistiniu ir statybos požiūriu didžiausio žemès paskirties keitimo potencialo teritorijos driekiasi monofunkcèse Vilniaus vietose, kur vyrauja monotoniška užstatymo struktūra ir santykinai skurdi architektūra, daugiausia Šeškinès, Naujininkų, Antakalnio, Žirmūnų ir kitų mikrorajonų teritorijose.

Skirtingų miesto dalių prioritetinè tvarka gali skirtis atsižvelgiant ị strateginius miesto tikslus, geopolitinę padètį, turimus finansinius išteklius ir (arba) norimą išspręsti miesto vystymo problemą.

\subsection{Geostatistinè apleistụ teritorijụ analizè ir ekonominès aplinkos Liverpulio mieste tyrimas}

Praktikoje AT antrinis panaudojamas matuojamas atsižvelgiant ị privataus verslo ekonominę naudą. Norint nustatyti ryši tarp ekonominès aplinkos ir AT realiomis sąlygomis, reikia pasirinkti patikimą ir reprezentatyvų duomenų šaltinį. Kadangi Lietuvoje iki šiol nèra sukurta tinkamos ekonominių rodmenų DB, tinkančios geokodavimui ir erdvinei analizei, tirti pasirinkti Vilniaus miesto urbanistine struktūra panašaus Didžiosios Britanijos miesto - Liverpulio - NT transakcijų duomenys. Šių duomenų šaltinis yra visuotinai pripažinta ir plačiai naudojama komercinè duomenų teikimo sistema CoStar. Naudojant šį duomenų šaltini, galima atlikti geokodavimą taikant Google Maps API duomenų apsikeitimo prieigą. Šiuo tyrimu siekiama identifikuoti ir ịvertinti AT bei ekonominès miesto aplinkos ryši taikant prielaidą, kad toks ryšys egzistuoja.

Gauti rezultatai vertinami kaip darantys prielaidas strateginiam didžiujų Europos miestų planavimui ir daro ịtaką formuojant ekonominių rodiklių grupę $C_{E}$ tolimesniame metodologijos etape (3.2 poskyris). Vilniaus ir Liverpulio miestų urbanistiniai parametrai lyginami 2.8 lentelèje.

Analizuojant AT nagrinejamos Liverpulio miesto AT ir NT sandorių sąsajos laike ir erdveje. Siekiant sujungti šias posistemes, remtasi tyrimo eigos planu, kuri sudaro keturios dalys (2.15 pav.).

Tyrimo etapai atlikti laikantis nustatyto eiliškumo. Šis tyrimo modelis gali būti taikomas bet kokio didmiesčio AT analizei, jeigu pradinių duomenų šaltiniai 
gali būti atvaizduojami geografiškai (pvz., atliekant geokodavimą ir taikant Google Maps API duomenų apsikeitimo platformą) ir laiko eilutèje.

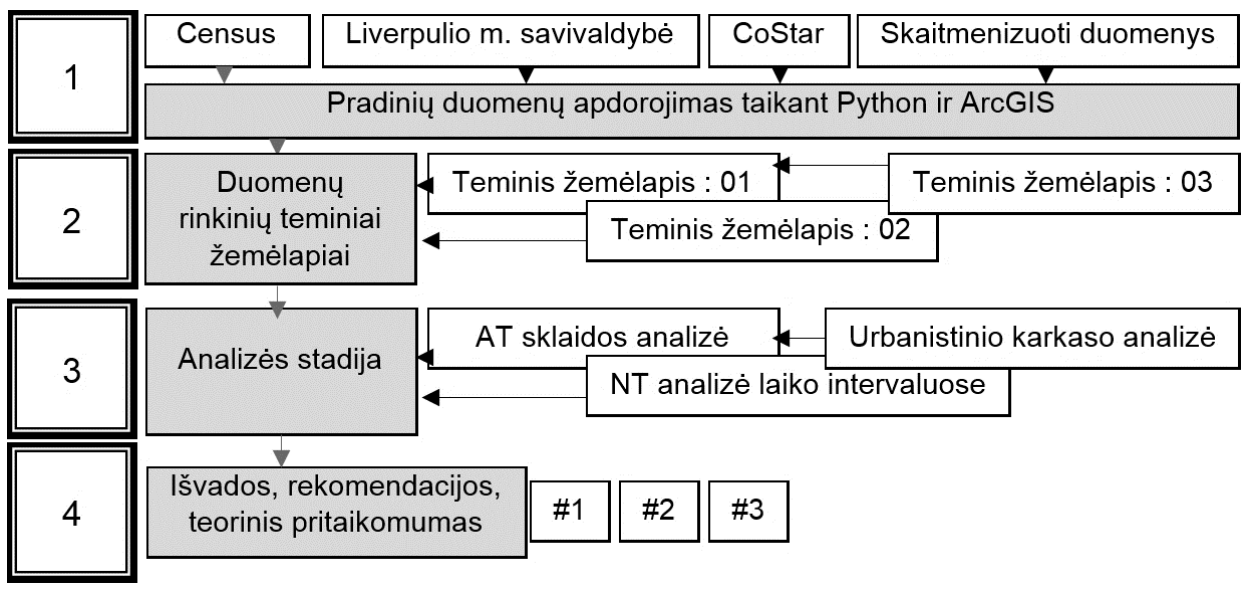

2.15 pav. Apleistų teritorijų ir nekilnojamojo turto rinkos Liverpulio mieste tyrimo schema (sudaryta autoriaus)

Fig. 2.15. The processes of the interaction between brownfields and the real estate market in Liverpool (created by author)

Šio tyrimo dalyje taikant 2.1 poskyryje pateiktas geostatistinès analizès priemones ir metodus, sujungti daugiaformačiai duomenys iš skirtingų duomenų šaltinių Liverpulio mieste. Tokiu būdu sudarytos DB, tinkamos ịvertinti ekonominès miesto aplinkos ir apleistų teritorijų erdvinị ir matematini ryšși. Pagrindiniai duomenų šaltiniai, sudarantys išteklių visumą, yra šie:

- Liverpulio miesto savivaldybès administracija. Šis išteklis suteikia prieigą prie Liverpulio miesto savivaldybès administracijos atvirų DB.

- Census. Tai duomenų rinkiniai, naudojami naujoms paslaugoms Liverpulio mieste ir prieigose plètoti bei kurti. Duomenys apima demografines populiacijos charakteristikas. Fiksuojami nedarbo lygio, sveikatos apsaugos, švietimo sistemos, namų ūkio rodikliai. Taip pat taikomos charakteristikos, apibrežiančios transporto sistemos ir kitų paslaugų apimtis ir kokybę (Liverpool City Council 2016). Šis duomenų šaltinis leidžia naudotis savivaldybès surinktais GIS duomenimis.

- Liverpulio regiono vietinès partnerystes asiociacija (toliau-LRVPA). Šis resursas suteikia prieigą prie LRVPA parengtų ir patvirtintų planavimo dokumentų. Daug dèmesio skirta City Region Innovation plan (Liverpool City Region 2016) šaltiniui, kuris apibrèžia pagrindines Liverpulio teritorijų planavimo gaires iki 2020 metų. 
- CoStar NT registro DB. Šis duomenų resursas leido skaitmeninti ir susisteminti NT sandorių įrašus 2006-2016 metais. Remiantis šia prieiga, susisteminami šio laikotarpio pramoninių, mažmeninès prekybos ir biuro patalpų NT įrašai pagal jų vietą mieste.

- Kita viešai prieinama informacija gauta taikant Google Maps API duomenų keitimosi paketą, suskaitmeninti 464 AT plotai Liverpulio miesto teritorijoje. Tai leido nustatyti jų sąveiką su urbanistine miesto struktūra ir ekonomine aplinka.

Iš viso skaitmeninti 478 NT sandoriai 2006-2016 metų CoStar DB įrašai. Šių įrašų pasiskirstymas erdvejje pateiktas 2.16 paveiksle. Surinkti duomenys ir su jais atlikti išvestiniai skaičiavimai pagal statistinès analizès formules ir pasitelkiant GIS technologiją.

Šie duomenys susisteminti pagal NT turto sandorių tipą:

- pramoninès paskirties objektų sandoriai (97 vnt., 20,34\%);

- mažmeninès prekybos objektų sandoriai (119 vnt., 24,96\%);

- biurų pastatų objektų sandoriai (261 vnt., 54,72\%).

Kiekvienas šių ịrašų kaupia duomenis apie sandorị: sandorio tipas, data, vertė ir vieta mieste. Tokiu būdu iš viso surinkta maždaug 2 tūkst. duomenų reikšmių apie NT sandorius Liverpulio mieste. Sugretinus šiuos duomenis su AT pasiskirstymu nagrinèjamoje teritorijoje, atlikta detali šių komponentų sąsajų analizè, kuri pateikta tolimesniuose poskyriuose.

2.8 lentelè. Vilniaus ir nagrinejjamos Liverpulio miesto dalies bendroji statistika (sudaryta autoriaus)

Table 2.8. The general statistics of Vilnius city and the investigated part of Liverpool city and generic (created by author)

\begin{tabular}{|l|c|c|}
\hline Parametras & Vilnius & Liverpulio miesto nagrinėjama dalis \\
\hline Plotas, $\mathrm{km}^{2}$ & 354,78 & 111,84 \\
\hline $\mathrm{AT}, \%$ & 2,59 & 2,53 \\
\hline Vidutinis AT dydis, ha & 0,92 & 0,67 \\
\hline Tankis, gyv./km² & 1,392 & 4,230 \\
\hline Gyventojų sk., mln. & $\approx 0,494$ & $\approx 0,473$ \\
\hline Karštieji taškai, vnt. & 6 & 5 \\
\hline
\end{tabular}

Statistinių parametrų palyginimas sudarè tinkamas sąlygas ịvertinti Vilniaus ir Liverpulio miestų pagrindinius panašumus ir skirtumus. Šio palyginimo rezultatai patvirtino iškeltą hipotezę, kad pagal vyraujantį gyventojų skaičiaus tankị mieste abieju miestų AT ekonominiai rodikliai gali būti analizuojami tarpusavyje. 

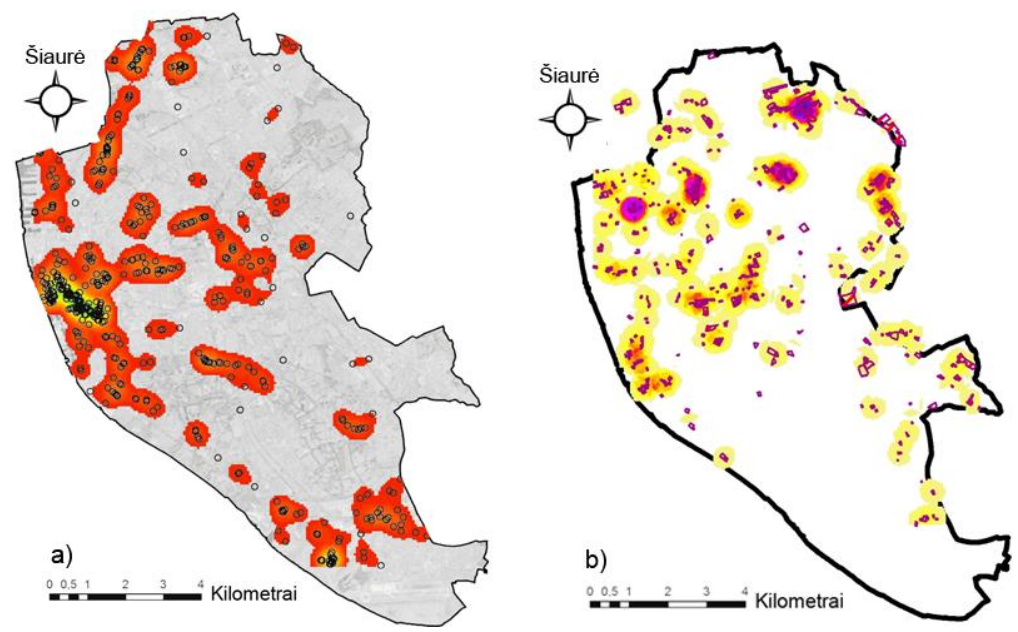

2.16 pav. Tiriamų elementų pasiskirstymas Liverpulio mieste: a) nekilnojamojo turto sandoriai 2006-2016 m.; b) apleistos teritorijos (sudaryta autoriaus)

Fig. 2.16. The distribution of investigated elements in Liverpool: a) real estate transactions for the period 2006-2016; b) urban of brownfields (created by author)

Duomenų sugretinimas ir agregavimas atliktas laikantis 2.1 poskyryje aprašytos tvarkos. Suskaitmenintu GIS duomenų apdorojimas atliktas taikant 2.12 poskyryje aprašytus metodus. Naudojant surinktus duomenis, atlikta AT sklaidos analize pagal AT skaičiaus pasiskirstymą pagal atstumą nuo miesto centro. Vilniaus ir Liverpulio miestų lyginamasis kiekio pasiskirstymo grafikas pateiktas 2.17 paveiksle. AT dažnio pasiskirstymas pagal atstumą nuo geografinio miesto centro sudaro tinkamas sąlygas kelti prielaidas dèl priemiestinių miesto zonų ir miesto dalių, kurioms turètų būti skirtas išskirtinis dèmesys, nustatymo.

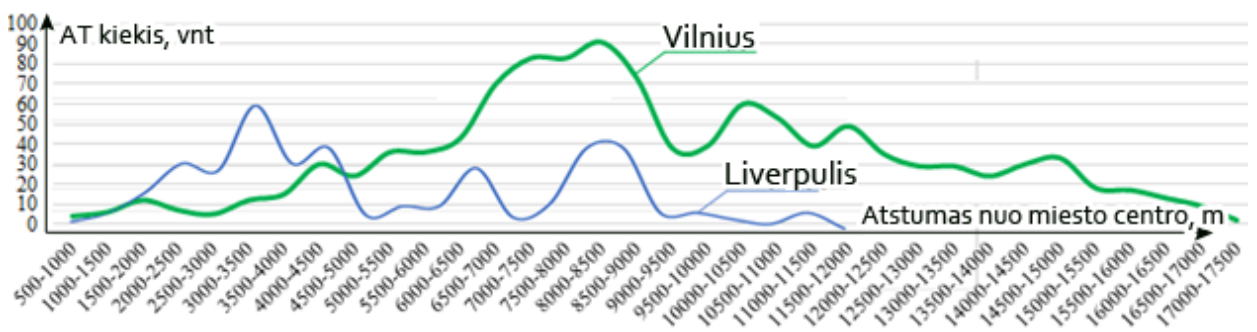

2.17 pav. Apleistų teritorijų pasiskirstymas pagal atstumą nuo miesto centro Vilniaus ir Liverpulio mieste (sudaryta autoriaus)

Fig. 2.17. The distribution of brownfields by distance from the city centre in Vilnius and Liverpool cities (created by author) 
Sklaidos kitimo grafikas atskleidžia pagrindinius skirtumus tarp nagrinëjamų miestų. Skirtingai negu Vilniaus mieste, kur daugiausia AT yra išsidèsčiusios $6,5-9,5 \mathrm{~km}$ spinduliu nuo miesto centro, Liverpulio mieste didžiausi sklaidos ekstremumai nustatyti $3,0-4,5 \mathrm{~km}$ ir 7,5-9,5 km atstumu nuo centrinès miesto dalies. Keliama prielaida, kad šis reiškinys rodo istorinius miesto plètros pokyčius NT rinkoje ir ekonominių svyravimų įtaką atsižvelgiant ị urbanistinį miesto karkasą. Remiantis šia prielaida ir žinant, kad vidutinis AT plotas Liverpulyje $27 \%$ mažesnis negu Vilniuje, galima teigti, kad Liverpulyje miesto plètra vykdoma laikantis ekonomių saugiklių, kad nesusiformuotu AT įskaitant jose esančius pastatus su inžinerine infrastruktūra.

Atliekant istorinių NT transakcijų duomenų analizę, išnagrinèta Liverpulio mieste atliktų NT sandorių įrašai nuo 2006 iki 2016 metų. Tyrimo objektas mažmeninès prekybos, pramonès ir biurų patalpų paskirties sandoriai. Atliekant tyrimą, remiamasi prielaida, kad visų nagrinėjamų paskirčių sandoriai atspindi bendrą miesto ekonomikos likvidumą ir esamą potencialą bei turi ryšį su AT sklaidos dinamika. Iš viso susisteminti 479 NT sandorių duomenys.

NT sandorių duomenys leidžia pažvelgti ị ekonominès miesto aplinkos potencialą konkrečiu periodu ir numatyti miesto kaip urbanistinès struktūros augimo ir susitraukimo tempus bei laiką. Siekiant išvengti duomenų perpildymo (angl. overfitting) problemos, duomenys agreguoti pagal metų ketvirčius. Duomenų imtis, apimanti 114 ménesių laikotarpi nuo $2006 \mathrm{~m}$. pirmojo iki 2016 m. antrojo ketvirčio pabaigos, atspindi NT transakcijos vertès ir sudarytų sandorių per laiko vienetą ịverčius (2.18 pav.).

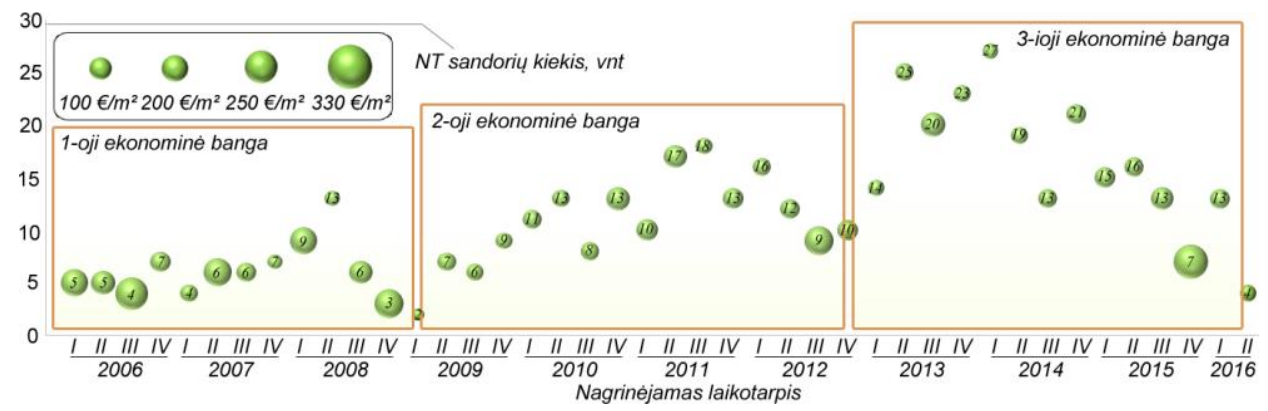

2.18 pav. Apibendrintas nekilnojamojo turto sandorių dažnio pasiskirstymas pagal vykdymo metus ir ketvirtị Liverpulio mieste (sudaryta autoriaus)

Fig. 2.18. A summary of the distribution of real estate transaction frequency by the year and quarter of performance in Liverpool (created by author)

Iš 2.18 paveiksle pateiktų duomenų matyti, kad atliktų NT sandorių dažnis cikliškai kito ir didèjo per pastarajị dešimtmetị. Naudojantis šio laikotarpi surinktais duomenimis, nustatyti trys sudarytų sandorių ciklai. 
Pirmasis iš jų vyko nuo $2006 \mathrm{~m}$. pirmojo ketvirčio iki $2008 \mathrm{~m}$. ketvirtojo ketvirčio. Antrasis - nuo 2009 m. pirmojo ketvirčio iki 2012 m. trečiojo ketvirčio. Trečiasis įvyko nuo $2012 \mathrm{~m}$. ketvirtojo ketvirčio iki $2012 \mathrm{~m}$. antrojo ketvirčio. NT sandorių skaičiaus prieaugio suminio kitimo pagal sektorių grafinè interpretacija pateikta 2.19 paveiksle.

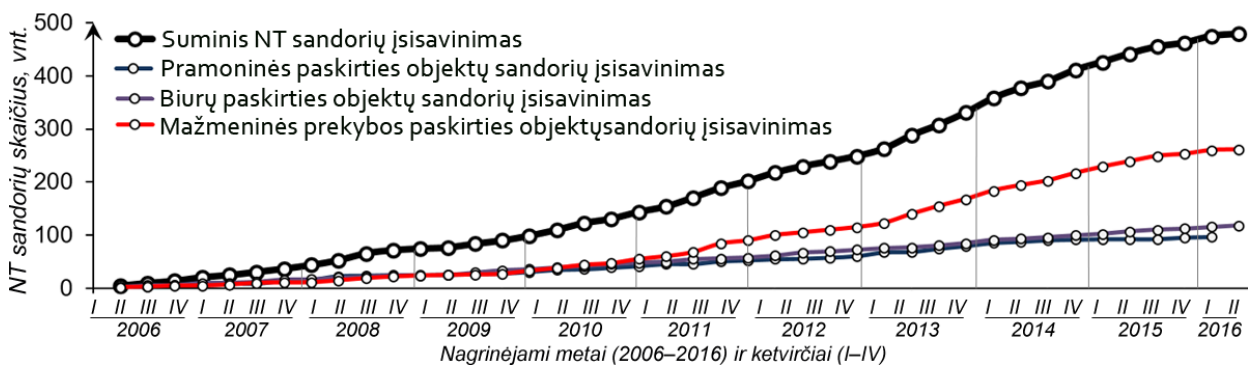

2.19 pav. Nekilnojamojo turto sandorių skaičiaus prieaugio suminis pokytis pagal sektorių Liverpulio mieste (sudaryta autoriaus)

Fig. 2.19. A cumulative variations in growth in the quantity of real estate transactions by sector in Liverpool (created by author)

Apskaičiuota, kad nagrinejjamuoju laikotarpiu didžiausios vertès NT sandoriai buvo atlikti isigyjant, naudojant esamus pastatus arba atliekant AT paskirties keitimą į biurų paskirties objektus (2.20 pav.). Vidutinė šio sektoriaus sandorio vertè nagrinèjamuoju laikotarpiu yra 5,2 mln. Eur, kai mažmeninès prekybos (toliau - MP) objektų - 2,5 mln. Eur, o pramoninès paskirties objektų tik 2,0 mln. Eur.

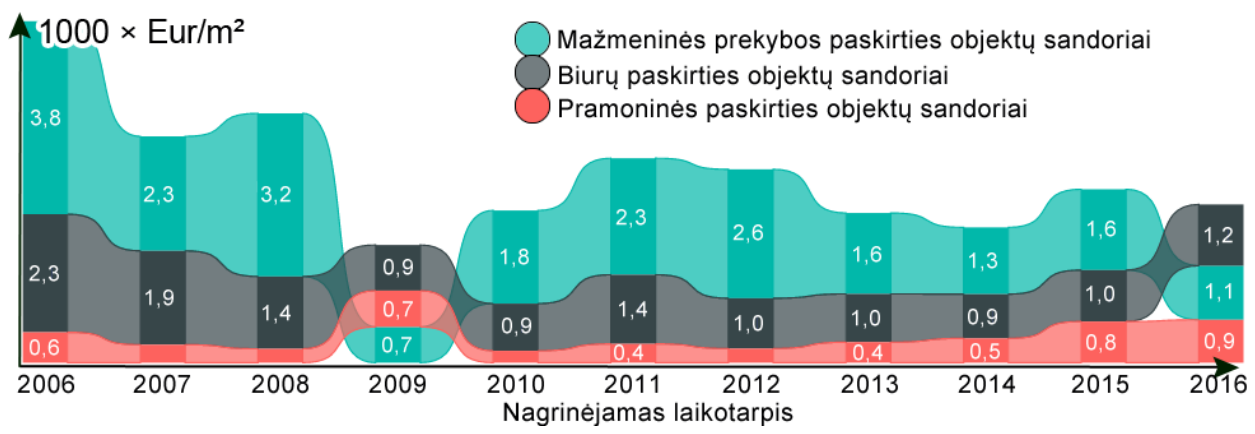

2.20 pav. Nekilnojamojo turto sandorių vidutinių verčių už $1 \mathrm{~m}^{2}$ pagal sektorių 2006-2016 m. Liverpulio mieste grafinè interpretacija (sudaryta autoriaus)

Fig. 2.20. The graphical interpretation of the average values of real estate transactions per square meter by sector for the period from 2006 to 2016 in Liverpool (created by author) 
Daugiausia NT transakcijų fiksuota prieškriziniu laikotarpiu (iki 2008 metų imtinai). Ekonominè krizė $2008 \mathrm{~m}$. labiausiai paveikè mažmeninès prekybos sektorių, kurio vidutinè transakcijų vertè sumažèjo $79 \%$.

Toliau nustatomas koreliacinio ryšys tarp AT ir NT transakcijų. Remiantis pirmiau pateiktomis analizėmis, NT sandorių duomenys buvo palyginti su erdvine AT Liverpulio mieste DB. Palyginus nagrinejjamus sandorius pagal sektorius ir AT vieta Liverpulio mieste, nustatytas erdvinis šių komponentų tarpusavio ryšys. Vienas svarbiausių dydžių, nusakančių šią tarpusavio sąveiką, yra atstumo nuo miesto centro erdvinè analizè. Nagrinèjamo laikotarpio sandorių kainų kitimo analizè pagal sektorių parodè, kad brangiausiai vertinami yra MP objektai. Vidutinė pastarojo dešimtmečio šios paskirties objektų sandorių vertė už kvadratinị metrą yra 200,1 Eur, už biuro paskirties sandorius - 117,9 Eur, o už pramonès paskirties - tik 45,8 Eur (2.21 pav.).

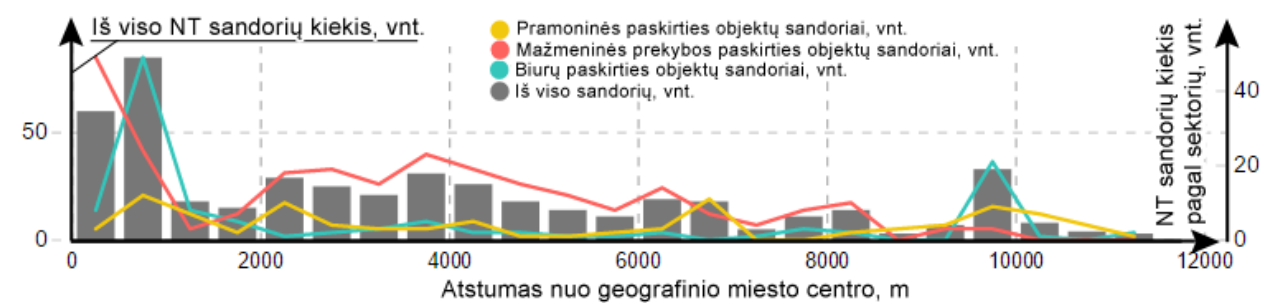

2.21 pav. Nekilnojamojo turto sandorių pagal sektorių ir apleistų teritorijų skaičiaus pasiskirstymas pagal atstumą nuo Liverpulio miesto centro (sudaryta autoriaus)

Fig. 2.21. The distribution of real estate transactions by sector and the ratio of brownfields according to the distance from the city centre in Liverpool city (created by author)

Apskaičiuota, kad egzistuoja 2.9 lentelëje pateiktos NT sandorių pagal sektorių koreliacijos koeficientai $R$ tarp jų vietos mieste ir atstumo nuo miesto centro.

2.9 lentelė. Koreliacijos koeficientų tarp nekilnojamojo turto sandorių sudarymo vietos atstumo nuo miesto centro ir apleistos teritorijos mieste reikšmès (sudaryta autoriaus) Table 2.9. The values of correlation coefficients between the distance of the real estate transactions from the city center and the brownfields in the city (created by author)

\begin{tabular}{|l|c|c|c|}
\hline $\begin{array}{l}\text { Statistinis } \\
\text { parametras }\end{array}$ & MP NT sandoriai & $\begin{array}{c}\text { Biurų paskirties NT } \\
\text { sandoriai }\end{array}$ & $\begin{array}{c}\text { Pramoninès paskirties } \\
\text { NT sandoriai }\end{array}$ \\
\hline$R$ & $-0,72$ & $-0,34$ & $-0,20$ \\
\hline Stiprumas & Stiprus & Silpnas & Labai silpnas \\
\hline
\end{tabular}


Rezultatai parodè, kad nuo 2011 m. sparčiai pradejjo daugèti MP NT sandorių. Ši reiškinị lėmè staigus ekonominès aplinkos potencialo augimas dẻl palankių sąlygų kurti smulkujį verslą. Tai lėmè AT ir jose esančių pastatų antrinį naudojimą atnaujinant senas komercines patalpas arba atliekant senų pastatų paskirties keitimą ị komercinę.

Nustatyta, kad ryšys tarp visų tipų NT sandorių lokacijos ir AT sklaidos yra silpnas. Teigiamas ryšys apskaičiuotas tik MP objektams. Investicijos i miesto ekonominę aplinką, kuriant papildomas darbo ir prekybos vietas, sudaro kliūtis AT ịsisenèti ir plisti, todèl ekonominès veiklos skatinimas AT koncentracijos vietose ir jų prieigose turi būti laikomas prioritetine planavimo kryptimi.

Taikant erdvinès analizès metodus, nustatyta, kad didžioji dalis MP objektų yra išsidèstę prie pagrindinių miestų gatvių ašių. Šios miesto gatvès atlieka jungiamają funkciją tarp tankiausiai apgyvendintų ir didžiausia darbo vietu koncentracija pasižyminčių miesto teritorijų. Šiuo atveju galioja LLL (angl. Location, Location Location) taisyklè, kai ekonominis objekto potencialas tiesiogiai priklauso nuo jo aprūpinamos teritorijos ploto ir lokacijos (Yıldız, Tüysüz 2018; Meirleir 2011).

Šio tyrimo veikimo modelis gali būti taikomas bet kokiam Europos miestui, pasižyminčiam panašia urbanistine ir demografine struktūra. Atskirai nagrinėjant sąsajos tarp AT ir ekonominès miesto aplinkos rodiklių galimus ateities pokyčius, rekomenduojama taikyti ML klastericazijos arba neuroninių tinklų modeliavimo principus, turint reprezentatyvią istorinių duomenų imtị.

\subsection{Apleistų teritorijų paskirties keitimo scenarijai}

Geostatistinès analizès rezultatai parodè, kad AT būdinga skirtinga vidinè ir išorinė aplinka, kuri gali būti išreiškiama kiekybiniais ir kokybiniais parametrais. Šie parametrai sudaro antrinio AT naudojimo galimybes pagal vietines sąlygas. Atsižvelgus ị ankstesnę AT paskirtį, AT paskirties keitimo scenarijus yra jas apibrežiančių veiksnių vertinimo rezultatas, igyvendinamas atsižvelgiant ị ekonomines ir socialines aplinkos sąlygas (Stillwell, Scholten 2001).

Esant istorinių duomenų stokai, atsižvelgus ị mieste dominuojančias funkcines zonas ir ị Vilniaus miesto teritorinių vienetų daugiafunkciškumą (2.9 pav.), apibrèžti šeši galimi AT paskirties keitimo scenarijai $T_{i}$ (2.10 lentelè).

Kiekvienas šių AT paskirties keitimo atvejų gali būti detalizuojamas vietovès lygmeniu. Tolimesniuose tyrimuose jos vertinamos strateginiu miestų planavimo lygmeniu. Paskirties keitimo scenarijai $T_{i}$ iš praktinès pusès gali būti vertinami dvejopai: kurie rodikliai yra svarbiausi keičiant AT paskirtị vienu iš $T_{i}$ atveju ir kuris geriausias AT paskirties keitimo scenarijus turi būti igyvendinamas konkrečiame strateginio planavimo lygmens miesto teritoriniame vienete. 
2.10 lentelè. Apleistų teritorijų paskirties keitimo scenarijai $T_{i}$

Table 2.10. Scenarios $T_{i}$ for changes in the purpose of brownfields

\begin{tabular}{|c|l|c|l|}
\hline Scenarijus & Galima nauja AT paskirtis & Scenarijus & Galima nauja AT paskirtis \\
\hline$T_{1}$ & Žalioji erdvė & $T_{4}$ & Pramoninè teritorija \\
\hline$T_{2}$ & $\begin{array}{l}\text { Komercinès paskirties } \\
\text { teritorija }\end{array}$ & $T_{5}$ & $\begin{array}{l}\text { Gyvenamosios paskirties } \\
\text { teritorija }\end{array}$ \\
\hline$T_{3}$ & Sporto aikštynai & $T_{6}$ & $\begin{array}{l}\text { Miesto rezervui priskiriamos } \\
\text { žemès, siekiant jas panaudoti } \\
\text { ateityje }\end{array}$ \\
\hline
\end{tabular}

Apibrèžti AT paskirties keitimo scenarijai $T_{i}$ yra miesto plètros strategijos, naudojant esamus AT plotus, igyvendinimo rezultatas. Galimas paskirties keitimo scenarijus $T_{i}$ turi būti nustatomas įvertinant konkrečios AT savybes ir aplink vyraujančios aplinkos savybes (ịvertinant AT pasiekiamumą artimiausių traukos centrų ir gyventojų koncentracijos taškų geografinę padètį) objektyviaisiais rodikliais.

\subsubsection{Teorinis apleistų teritorijų Vilniaus mieste paskirties keitimo igyvendinimo strategijos modelis}

Anksčiau aprašytos geostatistinès analizès rezultatai parodè, kad AT gali būti klasifikuojamos pagal prioritetą, vietą ir kitas būdingąsias savybes. Iki šiol nèra matematiškai, teisiškai ar istorine patirtimi pagrịstos strategijos, kuri, vertinant dugiafunkcius objektyviuosius aplinkos rodiklius, numatyti galimą AT naudojimo pobūdị, keičiant pradinę jų paskirtị ar jas sutvarkant.

Ivertinant esamus miesto poreikius ir prioritetus skirtinguose teritoriniuose vienetuose, nevienalytę socialinę ir ekonominę aplinką, būdingas vietovės savybes, AT paskirtis turi būti keičiama remiantis efektyvios miesto plètros principais. Parengta strategija (2.22 pav.), atsižvelgiant i Vilniaus miesto seniūnijų prioritetiškumo klasę (2.5 lentelè), AT suformuotus arealus Vilniaus miesto struktūroje ir dominuojančių funkcinių zonų apimtis bei geografines padètis.

Vidinè miesto plètra keičiant AT paskirtị yra strateginès reikšmès planavimo priemonè, kuri turi būti realizuojama laikantis iš anksto suplanuotų ir miesto stiprybes, silpnybes, galimybes ir grèsmes atitinkančių sąlygų. Parengtoje strategijoje AT paskirties keitimo procesai vykdomi keturiais etapais ir numatomi laikantis jų eiliškumo. Pirmajame etape AT paskirtis turi būti keičiama aukščiausio prioriteto miesto seniūnijose. Antrajame etape AT paskirtis turi būti keičiama tankiausiai apgyvendintose ir daugiausia verslo ir pramonès teritorijų turinčiose seniūnijose. Vilniaus mieste tai yra centrinès dalies prieigos, didelio užstatymo intensyvumo ir toliau nuo miesto centro esančios teritorijos. 
Trečiajame AT paskirties keitimo etape procesai vykdomi naujos statybos (nuo 2000 metų) būstų teritorijose, kuriose inžinerinè ir socialinè infrastruktūra nèra visapusiškai išplètota. Siekiant minimizuoti šiuos kaštus, AT gali būti vertinamos kaip neišnaudotas resursas šiai infrastruktūrai plètoti. Ketvirtajame strategijos etape AT paskirties keitimo procesai vykdomi periferineje miesto dalyje, kurioje paskirties keitimo poreikis yra mažiausias.

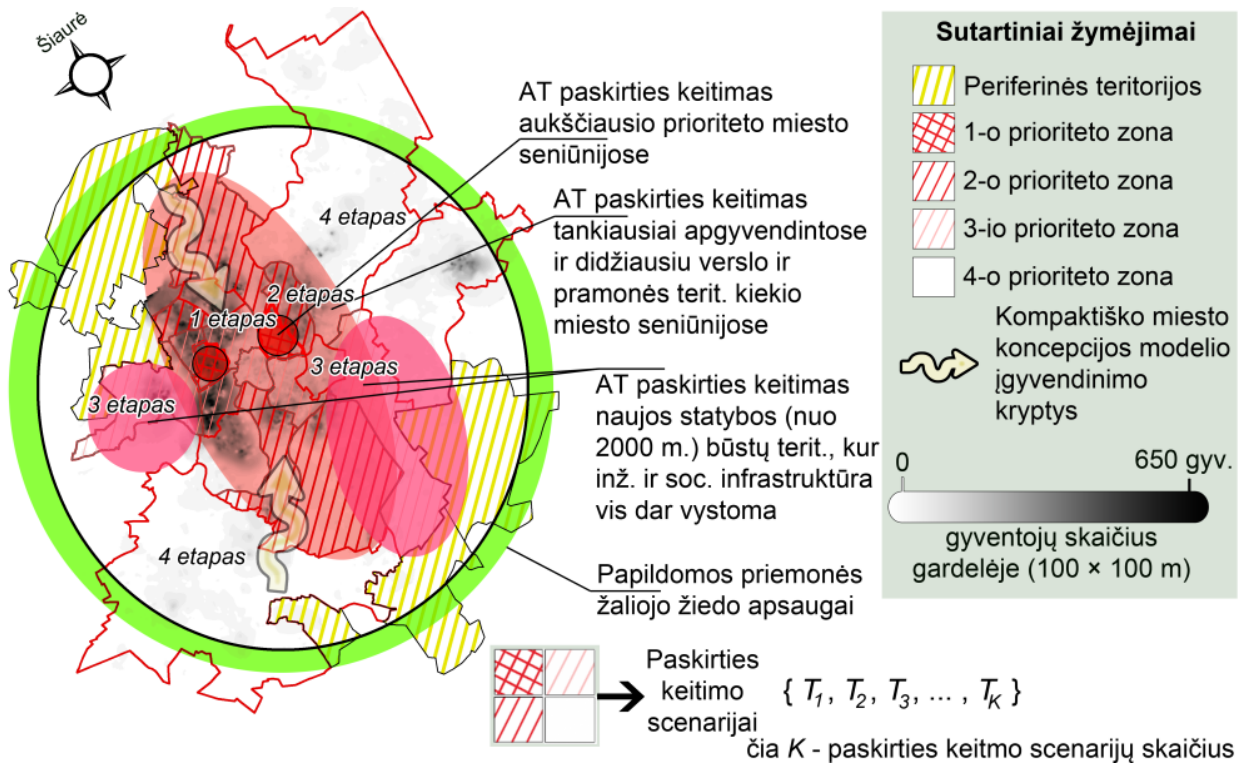

2.22 pav. Teorinis apleistų teritorijų paskirties keitimo strategijos modelis Vilniaus miesto atveju (sudaryta autoriaus)

Fig. 2.22. A theoretical model of the strategy for changes in the purpose of brownfields in Vilnius city (created by author)

Strategiją ịgyvendinant turi būti laikomasi kompaktiško miesto modelio. Tokiu būdu AT paskirties keitimo procesai nukreipiami ị kompaktiško miesto modelio formavimą, apsaugant už periferinès miesto dalies besidriekiantị žaliaji žiedą.

Laikantis darbe aprašytos metodologijos ir atsižvelgiant i jos teorinio taikymo rezultatus, turi būti parinktas tinkamiausias kiekvienos AT paskirties keitimo scenarijus $T_{i}$. 


\subsubsection{Apleistų teritoriju sutvarkymo koncepcijos miesto plètros strategijos kontekste}

Priklausomai nuo miesto vizijos AT paskirties keitimo strategija gali būti igyvendinama laikantis miesto poreikius atitinkančios koncepcijos. Vilniaus miesto atveju išskirtos trys pagrindinès prioritetinès miesto plètros kryptys. Jos aprašytos AT sutvarkymo koncepcijos miesto plètros strategijos kontekste (2.23 pav.). Pasirinktas socialinis, ekologinis ir ekonominis aspektas iliustruoja darniosios miesto plètros komponentus.

Realizuojant AT paskirties keitimo igyvendinimo strategiją ir atsižvelgiant i planavimo tikslus, pasirinkta viena iš apibrèžtų AT sutvarkymo koncepcijų. Bendruoju atveju koncepciją reikia vertinti kaip AT paskirties keitimo strategijos detalizavimą, pereinant iš strateginio ị vietovès lygmenį.

\begin{tabular}{|c|c|c|c|c|}
\hline 1 etapas & 2 etapas & 3 etapas & 4 etapas & Prioritetinè kryptis \\
\hline $\begin{array}{c}\text { Didžiausiu krimino- } \\
\text { geniniu aktyvumu } \\
\text { pasižyminčios terito- } \\
\text { rijos }\end{array}$ & $\begin{array}{l}\text { Centrinès miesto } \\
\text { teritorijos }\end{array}$ & $\begin{array}{l}\text { Toliau nuo miesto } \\
\text { centro nutolusios } \\
\text { pramoninès paskir- } \\
\text { ties teritorijos }\end{array}$ & $\begin{array}{c}\text { Žaliojo žiedo apsauga } \\
\text { atliekant AT paskirties } \\
\text { keitimą i žaliąsias } \\
\text { zonas }\end{array}$ & $\begin{array}{l}\text { Socialinis aspektas } \\
\text { (1 koncepcija })\end{array}$ \\
\hline $\begin{array}{c}\text { Žaliojo žiedo apsauga } \\
\text { atliekant AT paskirties } \\
\text { keitimą i žaliąsias } \\
\text { zonas }\end{array}$ & $\begin{array}{l}\text { Toliau nuo miesto } \\
\text { centro nutolusios } \\
\text { pramoninès paskir- } \\
\text { ties teritorijos }\end{array}$ & $\begin{array}{l}\text { Rekreacinių erdviu, } \\
\text { sporto aikštynu, parkų } \\
\text { planavimas atliekant } \\
\text { AT paskirties keitimą }\end{array}$ & $\begin{array}{l}\text { Didžiausiu krimino- } \\
\text { geniniu aktyvumu } \\
\text { pasižyminčios terito- } \\
\text { rijos }\end{array}$ & Ekologinis aspektas \\
\hline $\begin{array}{c}\text { Centrinès miesto } \\
\text { teritorijos }\end{array}$ & $\begin{array}{l}\text { Toliau nuo miesto } \\
\text { centro nutolusios } \\
\text { pramoninès paskir- } \\
\text { ties teritorijos }\end{array}$ & $\begin{array}{l}\text { Terit. bendruomeniu } \\
\text { (seniūnujū) centruose } \\
\text { esančių AT paskirties } \\
\text { keitimas į mišrią }\end{array}$ & $\begin{array}{l}\text { Inžinerinès ir socia- } \\
\text { linès infrastruktūros } \\
\text { vystymas rekreacinių } \\
\text { erdvių prieigos zonose }\end{array}$ & $\begin{array}{c}\text { Ekonominis aspektas } \\
\text { (NT vystytojai, privatus } \\
\text { kapitalas) }\end{array}$ \\
\hline
\end{tabular}

2.23 pav. Apleistų teritorijų sutvarkymo koncepcija (sudaryta autoriaus)

Fig. 2.23. A concept of brownfield development (created by author)

AT sutvarkymo koncepcijos skatina atkreipti dėmesi į vietinio lygmens miesto socialines ir ekonomines problemas (pavyzdžiui, nusikalstamumas, rekreacinių erdvių išsaugojimas ir apsauga, teritorinių bendruomenių poreikių užtikrinimas ir kt.). Šios koncepcijos yra rekomendacinio pobūdžio ir gali būti keičiamos atsižvelgiant ị kiekvieno miesto ypatybes ir planavimo tikslus.

Atsižvelgus i skaičiavimus, pasiūlyti AT sutvarkymo koncepcijoms igyvendinti integruotų paskirties keitimo scenarijų rinkiniai (3.14 pav.). 


\subsection{Antrojo skyriaus išvados}

1. Geostatistinès analizès metu atliktų skaičiavimų rezultatai atskleidè, kad vidutinis apleistų teritorijų kiekis seniūnijose yra didesnis nei deklaruojama miesto planavimo dokumentuose. Vienoje Vilniaus miesto seniūnijoje vidutiniškai yra 23 apleistos teritorijos. Priklausomai nuo seniūnijos funkcinio nevienalytiškumo, apleistų teritorijų plotas jose skiriasi iki 40 kartų. Mažiausias vidutinis apleistos teritorijos plotas nustatytas Fabijoniškių seniūnijoje (0,04 ha), didžiausias - Šeškinès (1,58 ha).

2. Vilniaus miesto periferinèse dalyse, kurių bendras plotas yra apie 11,2 tūkst. ha, yra 295,6 ha apleistų teritorijų. Tai sudaro beveik $2,64 \%$ visos periferinès miesto dalies teritorijos. Vidutinis apleistos teritorijos plotas $-0,54 \%$. Tai yra 0,23 ha daugiau, negu miesto urbanizuotose seniūnijose. Priemiestinès miesto dalies apleistoms teritorijoms būdingas didesnis monofukciškumas nei teritorijoms, esančioms urbanizuotoje miesto dalyje.

3. Koncentruotos plètros zonose apleistos teritorijos užima 66,28 ha, t. y. $6,31 \%$ šiu zonų ploto. Tai rodo, kad planavimo dokumentuose nèra atsižvelgiama ị apleistų teritorijų geografinị išsidèstymą, jų galimą pavojų socialinei, ekologinei, ekonominei ir urbanistinei aplinkai.

4. Sukurtas metodas leido nustatyti, kad yra statistinis ryšys tarp nekilnojamojo turto sandorių skaičiaus ir apleistų teritorijų tiesinio atstumo nuo geografinio Vilniaus miesto centro. Rezultatai parodè, kad didžiausias atstumo nuo miesto centro poveikis jaučiamas teritorijose, nuo miesto centro nutolusiose $6,5-9,5 \mathrm{~km}$. Likusios miesto dalies apleistų teritorijų savybėms didesnị poveikị daro kiti rodikliai.

5. Taikant sudarytą apleistas teritorijas apibūdinančių rodiklių duomenų bazę ir atlikus geostatistinę analizę, pasiūlytas būdas formuoti apleistų teritorijų paskirties keitimo strategiją. Remiantis šia strategija galima sudaryti sprendinių igyvendinimo koncepcijas, parengti apleistų teritorijų paskirties keitimo scenarijų rinkinius miestui. 



\section{Miesto apleistų teritorijụ paskirties keitimo scenarijų vertinimas}

Trečiajame skyriuje, remiantis atliktų tyrimų rezultatais ir ekspertinio vertinimo būdu apskaičiuotais rodiklių svoriu koeficientais, taikomi COPRAS, SAW, TOPSIS, DELFI ir EDAS DSPM metodai. Sukurta hierarchine AT ankstyvuju rodiklių sistema, kuria remiantis pasiūlyta AT sisteminio vertinimo sistema. Ji leidžia atlikti kompleksinį AT vertinimą skirtingose miesto dalyse nustatyti reikšmingiausius vertinimo rodiklius kiekvienu AT paskirties keitimo atveju ir parinkti tinkamiausias miesto vietas konkretiems AT paskirties keitimo scenarijams igyvendinti. Pateikti šeši anksčiau praktikoje netaikyti AT paskirties keitimo scenarijų koncepciniai modeliai, pritaikyti didmiesčiams.

Šio skyriaus medžiaga paskelbta trijuose straipsniuose (Burinskienè et al. 2015; Bielinskas et al. 2018; Bielinskas ir Burinskienè 2016).

\subsection{Apleistų teritorijų ir jụ paskirties keitimo scenarijų vertinimo algoritmas}

Darbe tyrimai vykdomi laikantis nustatyto eiliškumo atlikus 2 skyriuje aprašytą geostatistinę analizę. Tai yra duomenų paruošimo etapas, apimantis mokslinès 
literatūros analizę, duomenų skaitmenizavimą, kaupimą ir sisteminimą. Svarbiausias šio etapo žingsnis - hierarchinès AT rodiklių sistemos sudarymas. Remiantis šia sistema apibrezžti alternatyvieji rodikliai, leidžiantys įvertinti AT parametrus ịvairiais analizès aspektais (3.1 pav.).

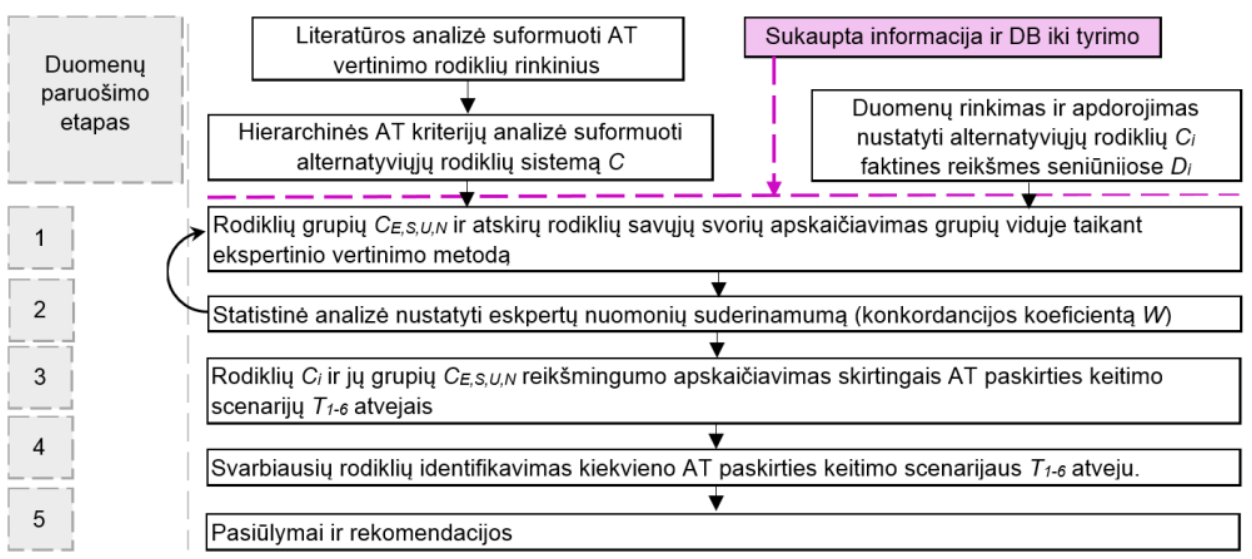

3.1 pav. Apleistų teritorijų rodiklių vertinimo algoritmas (sudaryta autoriaus)

Fig. 3.1. The algorithm for the evaluation of brownfield indicators (created by author)

Parengus duomenis, toliau paeiliui vykdomi penki skaičiavimų etapai. Jų metu apskaičiuojami savieji AT rodiklių ir jų grupių svoriai, nustatomas jų suderinamumas. Toliau AT vertinimo rodikliai ir jų grupès vertinami skirtingais paskirties keitimo atvejais. Gavus šių skaičiavimų rezultatus, toliau vertinamos skirtingos miesto seniūnijos (arba kiti teritorines bendruomenes identifikuojantys teritoriniai vienetai) pagal tinkamumą realiomis sąlygomis igyvendinti AT paskirties keitimo scenarijus. Tokiu būdu suformuota teritorinių vienetų prioritetinė eilute pagal tinkamumą jų geografine aprèptimi realizuoti skirtingos AT paskirties keitimo scenarijus. Atlikus šiuos tyrimus, parengiamos miesto strateginio planavimo gairès. Suformuojamos prielaidos ir pagrindiniai principai reglamentuoti strateginị miesto planavimą pagal gautus rezultatus.

\subsection{Apleistų teritorijų vertinimo rodiklių sistemos sudarymo būdas ir jo taikymas}

Mokslinejje literatūroje aptinkama gausybè ịvairių AT atgaivinimo procesus nagrinèjančių tyrimų metodų aprašymų. I tuos metodus būna įtraukti vienas ar keli svertiniai rodikliai, tarp kurių dažniausiai pasitaiko šie: 
- rizikos vertinimas (Semenzin et al. 2006; Strenge, Chamberlain 1995);

- urbanistini planavimą reglamentuojanti teisinè politika (Linkov et al. 2006);

- atkūrimo optimizacija (Bürger et al. 2007; Wang, McTernan 2002);

- finansiniai AT atgaivinimo kaštai (Kaufman et al. 2005);

- teigiamas AT poveikis aplinkai (Lange, McNeil 2004);

- infrastruktūros plètotè (Attoh-Okine, Gibbons 2001);

- miestu planavimas pagal biudžeto pajėgumus (Alvarez-Guerra et al. 2009; Stevens et al. 2007).

Apleistų pastatu likvidumo programoje (2008) teritorijos yra tiesiogiai susietos su jose esančiais pastatais, todèl AT vertinamos pagal atitinkamus tokių pastatų rodiklius (žemès nuosavybè, teisiškai pripažinti neužbaigti statiniai ir kt.). Regionai ir šalys formuojasi bei veikia skirtingomis socialinėmis bei ekonominėmis sąlygomis. Vienos teritorijos yra labiau pažeistos globalių pokyčių, kitos mažiau. Todèl nèra vienos ir absoliučiai pripažintos AT ankstyvujjų rodiklių sistemos, kurią galètume taikyti visiems miestams.

Remiantis Alexandrescu et al. (2018) ir Beames et al. (2015), pasiūlytas teritorijos gyvavimo ciklo modelis ir ,ankstyvujų rodiklių idejja“, kurią bandyta taikyti Green (2018). Darbe nustatyti išankstiniai rodikliai, galintys padèti numatyti teritorijos potencialą tapti apleista pačiame anksčiausiame teritorijos gyvavimo ciklo etape. Sprendžiant AT problematiką, ankstyvujų rodiklių vaidmuo apibrežziamas taip: šie įspètų suinteresuotus asmenis ar teritorijų planuotojus apie gresianti pavojų teritorijai tapti apleista.

Pabrěžtina tai, kad AT yra žmogaus ūkinès veiklos rezultatas, todèl jos negali būti priskiriamos savaiminiams procesams. Todèl šiuos procesus reikia reguliuoti atsižvelgiant ị aibę kiekybinių ir kokybinių rodiklių (Rosén et al. 2015; Morio et al. 2013) ir juos tarpusavyje grupuoti pagal jų poveikio tipą (Abdullahi, Pradhan 2015; Markevičius, Podviezko 2014; Saaty 1988). Pažymètina, kad pagal nė vieną iš rodiklių negalima daryti tikslios prielaidos prognozuoti AT atsiradimo arba plètros. Atlikus mokslinès literatūros apžvalgą, nustatyta, kad rodiklių, kuriais remiantis galima apibrěžti AT, yra daug ir ịvairių. Atrinkti 152 rodikliai, kurie gali būti tinkami tokiems vertinimams (3.2 pav.).

Būtų sudètinga apdoroti tokią gausą informacijos, todèl rodiklių skaičių būtina mažinti ir apsiriboti keliomis dešimtimis (Podvezko 2009). Analizuojant AT Lietuvos miestuose, reikia nustatyti pačius svarbiausius AT ankstyvuosius rodiklius. Praktiniu požiūriu pasirinktų rodiklių turètų būti ne daugiau kaip 15 (HOMBRE 2013). Darbe pateiktiems tyrimams ịvykdyti tiek rodiklių yra pakankama objektyviai išmatuoti AT kokybinius ir kiekybinius parametrus realiomis miesto sąlygomis. Kiekvienas rodiklis pagal jo poveikio tipą priskiriamas atitinkamai rodikliu grupei, kurių iš viso sistemoje yra keturios. Mažinant rodiklių skaičių, mažetų tikslumas ir informatyvumas. Siekiant to išvengti, rodiklių atrankai taikytas literatūros (Matos et al. 2018; CEEP 2014; CTLS 2011; EPA's Smart Growth... 2003; 
HOMBRE 2013; Mulliner et al. 2015; Prochorskaite et al. 2016) analize grindžiamas atrankos ir grupavimo bei ekspertinio vertinimo metodas.

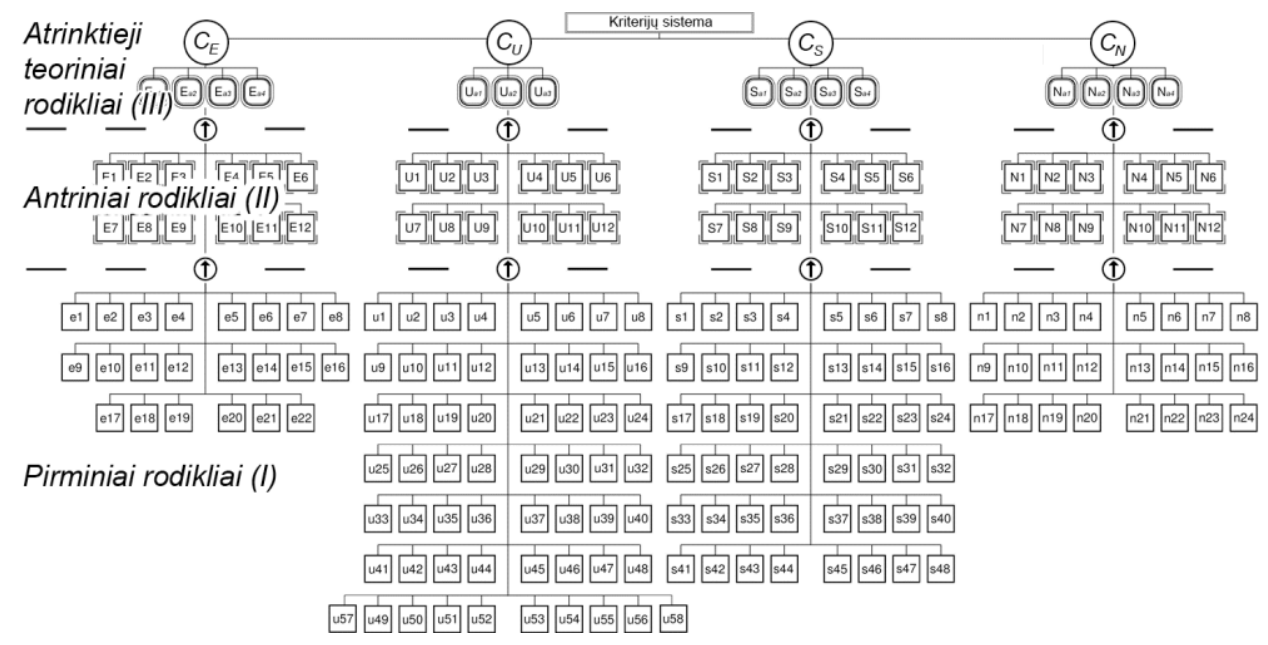

3.2 pav. Tyrime naudotų rodiklių hierarchinè sistema (sudaryta autoriaus)

Fig. 3.2. The hierarchical system of criteria used for research purposes (created by author)

Nagrinejjami rodikliai mokslinejje literatūroje priskirti tirti tam tikrą AT aplinką (Critto et al. 2006), mūsų atveju - socialinę, ekonominę, gamtinę ar fizinę (užstatymo ir infrastruktūros). Vykdant rodiklių atranką, išrinkti 22 ekonominiai, 48 socialiniai, 58 užstatymo (urbanistiniai) ir infrastruktūros, 24 gamtiniai pirminiai rodikliai (pirminių rodiklių poaibis - I, 3.2 paveikslai.). Daugelis jų mokslinèje literatūroje buvo minimi dažniau nei vieną kartą. Pasikartojantys rodikliai eliminuoti paliekant po vieną grupeje. Po pirmojo rodiklių atrankos etapo jų liko 48 (antriniai rodikliai - II).

Sprendžiant ekonomines, socialines ir technines problemas arba prognozuojant tam tikro proceso plètrą, mokslinių tyrimų praktikoje dažnai remiamasi ekspertų vertinimų metodu. Mokslininkai pabrèžia, kad ekspertų nuomonès ir požiūris ì sprendžiamą problemą dažnai skiriasi, gali būti prieštaringas (Podvezko 2005), tačiau šis metodas leidžia apibendrintą ekspertų grupès nuomonę priimti kaip galimą problemos sprendimą. Norint ji pagrịsti remiantis ekspertų vertinimu, būtina įvertinti ekspertų nuomonių suderinamumą. Jị galima patikrinti taikant DSPM (Завадскас 1987).

Ekspertinio vertinimo esmè tokia: remiantis sugrupuotais 48 atrinktais bendraisiais AT rodikliais (antriniai rodikliai II) po $12(j=1,2, \ldots, m$, čia $m=12)$ kiekvienoje grupeje (4 grupès) ir ekspertavimo anketomis, nustatyti 
15 reikšmingiausių AT ankstyvujų rodiklių (3.2 pav.). Antriniai AT ankstyvieji rodikliai kiekvienoje grupeje pateikti B priedo B.1 lenteleje.

Anketos paskyrimą konkrečiam ekspertui $\left(G_{1}, G_{2}, G_{n}\right)$ lèmè užsibrèžtos sąlygos: apklausoje turètų dalyvauti ekspertai, turintys aukštaji išsilavinimą, dirbantys ir turintys ne mažiau kaip penkerių darbo metų praktikos teritorijų planavimo, socialinèje, ekonomineje, aplinkosaugos bei projektavimo srityse. Anketos pateiktos savivaldybių teritorijų planuotojams, taip pat savivaldybių investicijų, socialinès paramos skyriaus darbuotojams, praktikams, rengusiems teritorijų planavimo dokumentus (architektūrinès, socialinès, ekonominès, gamtinès, inžinerinès ir susisiekimo infrastruktūros dalies rengèjai), ne pelno siekiančių organizacijų atstovams, sprendžiantiems bendrąsias savivaldybių problemas, projektuotojams, inžinieriams. Taip pat aplinkosaugos srityje dirbantiems patyrusiems ir atitinkamus atestatus turintiems specialistams, kurie galètų parengti reikiamus dokumentus planuojamai ūkinei veiklai. Kiekvienos grupès ankstyviesiems rodikliams įvertinti anketas užpildè 10 ekspertų $(i=1$, $2, \ldots, n$, čia $n=10$ ) pagal atitinkamą darbo sritị.

\subsubsection{Ekspertinio vertinimo tvarka}

Ekspertinis vertinimas atliktas norint atrinkti svarbiausius AT vertinimo rodiklius (III) iš antrinių rodiklių (II) poaibio. Vadovaujantis darbo patirtimi, pasirinktų ekspertų buvo prašoma įvertinti tyrejų parengtoje anketoje pagal grupes suskirstytus rodiklius $\left(\left[C_{1}, \mathrm{C}_{2}, \ldots, C_{m}\right]\right)$ ir atsakyti ị užduotą klausimą - kurių rodiklių stebejjimas ir ilgalaikiai pokyčiai yra svarbiausi, kad būtų galima įspèti apie tikimybę šiai teritorijai tapti apleista arba nenaudojama? Kiekvienos grupès (ekonominès, socialinès, užstatymo ir infrastruktūros bei gamtinès) rodikliai vertinami balais $\left(B_{1}, B_{2}, \ldots, B_{m}\right)$ pagal 10 balų sistemą. Didžiausias balų skaičius (10) suteikiamas svarbiausiam (prognozės aspektu) grupès rodikliui, îspejjančiam, kad teritorija ateityje gali tapti apleista, mažiausias balų skaičius (0) - mažiausiai svarbiam grupès rodikliui. Šis ekspertų vertinimas rodo ekspertų teikiamą pirmenybę atskirų grupių rodikliams, o remiantis suteiktais balais, nustatyti jų svoriai. Tokiu būdu išskirta 15 pačių svarbiausių AT ankstyvųjų rodiklių.

Iš ekspertų užpildytų ir tyrèjams grąžintų anketų kiekvieno eksperto grupès rodikliams suteikti svarbos ịverčiai $B$ surašyti ị lenteles. Ekonominès grupès rodiklių atvejo pavyzdys pateiktas B priedo B.2 lentelèje.

Ekspertai ịvertino $C_{S, U, N}$ grupių AT rodiklius laikydamiesi tokios pačios duomenu pateikimo tvarkos.

Suvedus ekspertų apklausos duomenis, atliekami skaičiavimai pagrịsti jų nuomonès suderinamumą. Jei ekspertų yra daugiau nei du, grupès ekspertų suderinamumo lygị rodo konkordancijos koeficientas (Kendel 1975; Čekanavičius, Murauskas 2004). Apskaičiuota visų rodiklių rangų standartinių deviacijų kvadratų 
suma parodo, ar ekspertų vertinimai labai skiriasi nuo bendrojo vidutinio vertinimo. Todèl ekspertizès patikimumas gali būti išreiškiamas ekspertų nuomonių konkordancijos koeficientu, kuris rodo individualių nuomonių panašumo laipsnį. Konkordancijos koeficiento $W$ reikšmès svyruoja intervalu nuo 0 iki 1 (sutapus visiems rangams konkordancijos koeficientas lygus 1). Kuo didesnis konkordancijos koeficientas, tuo stipresnè kintamųu koreliacija.

Konkordancijos koeficientui apskaičiuoti rodikliai ranguojami pagal ekspertų vertinimą (Podvezko 2005). Tai atliekama tokiu būdu: pačiam svarbiausiam rodikliui suteikiamas vieneto rangas, antrajam pagal svarbą - vienetu didesnis rangas ir t. t., kol paskutiniam pagal svarbą rangui suteikiamas skaičius $m$, t. y. skaičius, lygus rodiklių skaičiui grupeje. Jei kelių rodiklių svarba, eksperto nuomone, yra vienoda, tuomet abiem rodikliams suteikiamas vienodas rangas (Кремер 2003). Ekspertų suteikti įverčiai $\left(B_{i j}\right)$ paverčiami rangais $\left(R n_{i j}\right)$ (3.2 lentelè.). Rangavimas rodo hierarchiją, o kiekvienas rangas rodo svarbos ịverčių lygmeni hierarchinèje sistemoje. Keičiant balus rangais, taikyta (3.1) formulè:

$$
R_{i j}=(m+1)-B_{i j},
$$

čia $B_{i j}-i$-tojo eksperto $(i=1,2, \ldots, n) j$-ajam rodikliui suteiktas svarbos įvertis (balas) $(j=1,2, \ldots, m) ; n$ - ekspertų skaičius; $m$ - rodiklių skaičius.

Ekspertų nuomonių rangai ekonominejje rodiklių grupejje pateikti 3.1 lentelëje.

Ekspertų nuomonių suderinamumas nustatomas skaičiuojant konkordancijos koeficientą $W$. Konkordancijos koeficientas susijęs su kiekvieno rodiklio rangų suma visų ekspertų atžvilgiu (Kendall 1975). Vidutinis kiekvieno rodiklio rangas apskaičiuojamas pagal (3.2) formulę:

$$
\overline{R_{j}}=\frac{\sum_{j=1}^{n} R_{i j}}{n},
$$

čia $R_{j}-i$-tojo eksperto $j$-ajam rodikliui suteiktas rangas; $n$ - ekspertų skaičius.

Kiekvieno rodiklio rangų suma $R_{j}$ visų ekspertų atžvilgiu apskaičiuojama pagal (3.3) formulę.

$$
R_{j}=\sum_{i=1}^{n} R_{i j}(j=1,2, \ldots m)
$$

Dydžių $R_{j}$ standartinès deviacijos nuo kvadratų sumos $S$ dar tiksliau apibrèžia sąsają su konkordancijos koeficientu. Šis dydis apskaičiuojamas pagal (3.4) formulę.

$$
S=\sum_{j=1}^{m}\left(R_{j}-\bar{R}\right)^{2}
$$


Bendrasis vidurkis $\bar{R}$ apskaičiuojamas pagal (3.5) formulę.

$$
\bar{R}=\frac{\sum_{i=1}^{n} \sum_{j=1}^{m} R_{i j}}{m} .
$$

Pateiktos formulès (3.1)-(3.5) naudojamos apskaičiuojant ekspertinio vertinimo parametrus 3.1 lentelèje.

3.1 lentelè. Ekspertų nuomonių rangai ekonominèje rodiklių grupeje $\left(C_{E}\right)$ ir jų naudojimas antrinių rodiklių poaibiui skaičiuoti

Table 3.1. Expert position rankings in the group of economic criteria $\left(C_{E}\right)$ and their use for calculating a subset of secondary criteria

\begin{tabular}{|c|c|c|c|c|c|c|c|c|c|c|c|c|}
\hline \multirow{2}{*}{$\begin{array}{c}\text { Eksperto } \\
\text { kodas } \\
i=1, \ldots, n\end{array}$} & \multicolumn{12}{|c|}{ Kriterijaus žymuo ir jo rangas, $j=1,2, \ldots, m$} \\
\hline & $C_{1}$ & $C_{2}$ & $C_{3}$ & $C_{4}$ & $C_{5}$ & $C_{6}$ & $C_{7}$ & $C_{8}$ & $C_{9}$ & $C_{10}$ & $C_{11}$ & $C_{12}$ \\
\hline$G_{1}$ & 10 & 4 & 11 & 12 & 9 & 8 & 4 & 3 & 6 & 8 & 7 & 5 \\
\hline$G_{2}$ & 10 & 9 & 8 & 10 & 9 & 8 & 8 & 9 & 9 & 7 & 8 & 6 \\
\hline$G_{3}$ & 5 & 8 & 11 & 12 & 9 & 10 & 9 & 3 & 4 & 7 & 8 & 5 \\
\hline$G_{4}$ & 10 & 8 & 10 & 12 & 12 & 11 & 9 & 5 & 3 & 5 & 8 & 11 \\
\hline$G_{5}$ & 8 & 8 & 6 & 12 & 12 & 12 & 10 & 5 & 12 & 5 & 10 & 7 \\
\hline$G_{6}$ & 11 & 4 & 8 & 10 & 12 & 9 & 7 & 4 & 13 & 10 & 13 & 3 \\
\hline$G_{7}$ & 5 & 6 & 5 & 6 & 6 & 5 & 5 & 4 & 5 & 5 & 7 & 6 \\
\hline$G_{8}$ & 8 & 5 & 9 & 8 & 6 & 7 & 3 & 3 & 13 & 8 & 8 & 4 \\
\hline$G_{9}$ & 4 & 5 & 8 & 6 & 3 & 6 & 3 & 4 & 7 & 7 & 9 & 5 \\
\hline$G_{10}$ & 6 & 4 & 4 & 6 & 5 & 5 & 4 & 4 & 5 & 6 & 7 & 4 \\
\hline$\sum_{i=1}^{n} R_{i j}$ & 77 & 61 & 80 & 94 & 83 & 81 & 62 & 44 & 77 & 68 & 85 & 56 \\
\hline$\overline{R_{j}}$ & 7,7 & 6,1 & 8 & 9,4 & 8,3 & 8,1 & 6,2 & 4,4 & 7,7 & 6,8 & 8,5 & 5,6 \\
\hline$\sum_{i=1}^{n} R_{i j}-\bar{R}$ & 12 & -4 & 15 & 29 & 18 & 16 & -3 & -21 & 12 & 3 & 20 & -9 \\
\hline$\left[\sum_{i=1}^{n} R_{i j}-\bar{R}\right]^{2}$ & 144 & 16 & 225 & 841 & 324 & 256 & 9 & 441 & 144 & 9 & 400 & 81 \\
\hline
\end{tabular}

Konkordancijos koeficientas $W$ apskaičiuojamas pagal (3.6) formulę (Завадскас 1987):

$$
W=\frac{12 \times S}{n^{2} \times\left(m^{2}-m\right)} .
$$


Jei rodiklių skaičius $m>7$ (tyrimo atveju - $12>7$ ), tai konkordancijos koeficiento $W$ reikšmingumas gali būti nustatytas taikant Pirsono rodiklių $\chi^{2}$ (Kendall 1975, 3.7 formulè):

$$
\chi^{2}=n \times(m-1) \times W=\frac{12 \times S}{n \times m \times(m+1)} .
$$

Atsitiktinis dydis yra pasiskirstęs pagal $\chi^{2}$ skirstinị esant $v=m-1$ laisvès laipsniui. Reikšmingumo lygmuo $\alpha$ imamas 0,05 (dažniausiai praktikoje taikoma $\alpha$ reikšmè) ir pagal $\chi^{2}$ skirstinio lentelę nustatoma kritinè reikšmé $\chi_{k r}^{2}=\chi_{v, \alpha}^{2}$.

(3.4), (3.6) ir (3.7) formulèse pateiktų parametrų reikšmes taip pat galima apskaičiuoti taikant neparametrinę statistinę analizę (3.14, 3.16-3.18 formules). Jei, atlikus skaičiavimus, gaunama nelygybe $\chi^{2}>\chi_{k r}^{2}$, tai rodo, kad ekspertu vertinimai suderinti. Šių skaičiavimų rezultatai pateikti 3.2 lentelèje.

3.2 lentelè. $C_{E}, C_{S}, C_{U}$ ir $C_{N}$ grupių rodiklių ekspertų vertinimo suderinamumo skaičiavimų rezultatai

Table 3.2. The calculation results of the compatibility of expert evaluation in the groups of criteria $C_{E}, C_{S}, C_{U}$ and $C_{N}$

\begin{tabular}{|l|c|c|c|c|}
\hline \multirow{2}{*}{ Parametras } & \multicolumn{4}{|c|}{ Rodikliụ grupės } \\
\cline { 2 - 5 } & $C_{E}$ & $C_{S}$ & $C_{U}$ & $C_{N}$ \\
\hline$S$ & 2890 & 2851 & 3808 & 2558 \\
\hline$W$ & 0,202098 & 0,199371 & 0,266294 & 0,178881 \\
\hline$\chi^{2}$ & 22,23077 & 21,93077 & 29,29231 & 19,67692 \\
\hline$\chi_{k r}^{2}$ & \multicolumn{5}{|c|}{19,6751} \\
\hline Vertinimas & \multicolumn{5}{|c|}{ Ekspertų rodiklių vertinimo suderinamumo sąlygos $\chi^{2}>\chi_{k r}^{2}$} \\
& \multicolumn{4}{|c|}{ tenkinimo ivertinimas } \\
\hline Rezultatai & Taip & Taip & Taip & Taip \\
\hline
\end{tabular}

Skaičiavimų rezultatai leidžia teigti, kad ekspertų $C_{E}, C_{S}, C_{U}$ ir $C_{N}$ grupių rodiklių vertinimai suderinti.

Praktikoje atliekant kai kuriuos skaičiavimus, patogiau taikyti reikšmingumo rodiklius, kurių geriausia vertė yra didžiausia skaitinė išraiška (Завадскас 1987; Ginevičius et al. 2013; Gudiene et al. 2014). Rodiklių svarbumo reikšmès nustatomos apskaičiuojant dydi $\bar{q}_{j}$ pagal (3.8) formulę. 


$$
\bar{q}_{j}=\frac{\bar{R}_{j}}{\sum_{i=1}^{m} R_{j}} .
$$

Normalizavus rangus, svarbiausias rodiklis yra tas, kurio apskaičiuotoji vertè yra mažiausia. Galutinès vertès nustatomos kiekvienam rodikliui apskaičiavus atvirkštini $\bar{q}_{j}$ dydị, o paskui kiekvieno iš jų reikšmingumo rodiklį $Q_{j}$. Apskaičiuotų rodiklių reikšmingumo rodiklių suma lygi 1.

Atvirkštinis dydis $d_{j}$ skaičiuojamas taikant (3.9) formulę, o kiekvieno rodiklio reikšmingumo rodiklis $Q_{j}-$ taikant (3.10) formulę (Sivilevičius 2012). Reikšmingumo rodiklis $Q_{j}$ leidžia įrodyti rodiklių svarbą juos lyginant ir nustatyti, kiek kartų vienas rodiklis yra svarbesnis už kitą. Pasirinktas būdas ịgalina atrinkti pačius svarbiausius rodiklius kiekvienoje grupeje ir sudaryti 15 svarbiausių rodiklių sąrašą.

$$
\begin{gathered}
d_{j}=1-\bar{q}_{j}, \\
Q_{j}=\frac{(m+1)-\bar{R}}{\sum_{i=1}^{m} \bar{R}_{j}},
\end{gathered}
$$

čia $m$ - AT atsiradimo savybes rodančių rodiklių skaičius; $\bar{R}_{j}-j$-ojo rodiklio vidutinis rangas, apskaičiuotas pagal (3.2) formulę.

Aptartų AT vertinimo rodiklių grupių $C_{S, E, N, U}$ svarbumo hierarchijos nustatymo reikšmès pateiktos B priede.

\subsubsection{Svarbiausių apleistų teritorijų ankstyvųjų ir alternatyviujjų rodiklių atranka}

Remiantis pateiktų skaičiavimų rezultatais, atrinkti 15 pačių svarbiausių AT ankstyvụjų vertinimo rodiklių (3.3 lentelè) visose $C_{E, S, U, N}$ rodiklių grupėse.

Atsižvelgus ì sudarytą geoerdvinių duomenų bazę, rodikliai $C_{i}$, esantys 3.3 lentelèje, pakeisti alternatyviaisiais 18 faktinių rodiklių $\left(\left\{E_{1}, \ldots, E_{4}\right\} \in C_{E} ;\left\{U_{1}, \ldots, U_{5}\right\} \in C_{U} ;\left\{S_{1}, \ldots, S_{5}\right\} \in C_{S} ;\left\{N_{1}, \ldots, N_{4}\right\} \in C_{N}.\right)$.

Teoriniame skaičiavimo modelyje nustatyti rodikliai sutampa su tyrimo metu prieinamais duomenimis tik idealiu atveju. Alternatyviụjų rodiklių ịvedimas ị skaičiavimus sudaro tinkamas sąlygas pritaikyti teorini skaičiavimo modelị praktikoje panaudojant turimus duomenis, padaro modeli lankstesni ir labiau išreiškiantị tiriamąsias miesto savybes. 
3.3 lentelė. Apskaičiuoti svarbiausių ankstyvų apleistų teritorijų rodiklių svoriai grupėse $C_{i}$

Table 3.3. The calculated weights of the most significant (final) criteria for the initial brownfields in groups $C_{i}$

\begin{tabular}{|c|c|}
\hline \multicolumn{2}{|c|}{ Rodiklių grupès } \\
\hline$C_{E}$ & $C_{S}$ \\
\hline $\begin{array}{l}\text { Santykis tarp turto kainos savivaldybejje } \\
\text { ir gretimose savivaldybėse }\left(Q_{j}=0,079\right)\end{array}$ & Ilgalaikis nedarbo lygis $\left(Q_{j}=0,098\right)$ \\
\hline NT vertè $\left(Q_{j}=0,085\right)$ & $\begin{array}{l}\text { Žmonių, gyvenančių žemiau skurdo } \\
\text { ribos, procentas }\left(Q_{j}=0,099\right)\end{array}$ \\
\hline $\begin{array}{l}\text { Investicijos (privatus ir viešasis } \\
\text { sektorius) }\left(Q_{j}=0,099\right)\end{array}$ & $\begin{array}{l}\text { Faktinės vidutinės gyventojų pajamos } \\
\left(Q_{j}=0,093\right)\end{array}$ \\
\hline $\begin{array}{l}\text { Erdvinis neatitikimas tarp darbuotojų ir } \\
\text { darbo vietų }\left(Q_{j}=0,078\right)\end{array}$ & Nusikalstamumo lygis $\left(Q_{j}=0,093\right)$ \\
\hline \multicolumn{2}{|c|}{ Rodiklių grupès } \\
\hline$C_{U}$ & $C_{N}$ \\
\hline Laisvųjų sklypų plotas $\left(Q_{j}=0,082\right)$ & $\begin{array}{l}\text { Dirvožemio (grunto) užterštumo lygis } \\
\left(Q_{j}=0,112\right)\end{array}$ \\
\hline $\begin{array}{l}\text { Naujų statybos leidimų skaičius } \\
\left(Q_{j}=0,072\right)\end{array}$ & $\begin{array}{l}\text { Išmetamosios medžiagos iš vietinių } \\
\text { taršos šaltinių }\left(Q_{j}=0,115\right)\end{array}$ \\
\hline \multirow{2}{*}{$\begin{array}{l}\text { Infrastruktūros elementų įrengimo } \\
\text { amžius }\left(Q_{j}=0,074\right)\end{array}$} & $\begin{array}{l}\text { Žaliųjų plotų skaičius, tenkantis 1-am } \\
\text { gyventojui }\left(Q_{j}=0,126\right)\end{array}$ \\
\hline & $\begin{array}{l}\text { Transporto priemonių išmetamųų teršalų } \\
\text { lygis }\left(Q_{j}=0,105\right)\end{array}$ \\
\hline
\end{tabular}

Ekonominiu rodiklių grupeje $C_{E}$ atrinkti svarbiausieji AT ankstyvieji vertinimo rodikliai:

- $E_{1}$ - skirtos investicijos į aplinką. Jos parodo, kiek santykinai lèšų nuo 2014 m. investuota ị nagrinèjamą seniūniją kitų atžvilgiu. İvertinus ši rodiklị, galima aiškiau apibrèžti nagrinèjamos seniūnijos $D_{i}$ perspektyvas keistis ir prisitaikyti prie gyventojų poreikių.

- $E_{2}$ - statybos kaina. Ji parodo vidutinę per pastaruosius dvejus metus vykdytų NT projektų statybos kainą. Šis dydis atspindi bendrąsias statybų apimtis kiekvienoje seniūnijoje $D_{i}$.

- $E_{3}$ - patvirtintos ES programos. Kriterijus reprezentuoja gautu ir panaudotų investicijų apimtis pagal ES ir kitų finansinių fondų asignavimų programas. Šis dydis gali ryškiai skirtis kiekvienoje seniūnijoje priklausomai nuo ekologinès, socialinès aplinkos ir savivaldybès nustatytų potencialios plètros zonų ribų.

- $E_{4}$ - darbo vietos (perteklius / stygius). Nagrinèti miesto BP sprendiniai, apibrèžiantys darbo vietų koncentracijų zonas ir kiekius. Šie duomenys palyginami su Statistikos departamento duomenimis, ịvertinant darbingu 
gyventojų skaičių seniūnijoje. Gautas dydis parodo darbo vietų trūkumą arba perteklių.

Urbanistinių ir infrastruktūros rodiklių grupejje $C_{U}$ atrinkti svarbiausieji AT ankstyvieji vertinimo rodikliai:

- $U_{1}$ - nenaudojamos žemès plotai. Ivertinama bet kokios funkcinès paskirties žemė, kurioje nèra vykdoma jokia ūkinè veikla, kuri yra pažeista ar nenaudojama miesto ir miesto gyventojų reikmèms patenkinti.

- $U_{2}$ - gyvenamujjų objektų skaičius. Jis leidžia ịvertinti gyventojų skaičių konkrečioje teritorijoje, užstatymo tankumą ir poreikị planuoti būstus gyventojų reikmėms tenkinti.

- $U_{3}$ - pastatų amžius. Išryškina vidutini seniūnijos gyvenamojo fondo amžių. Šis ịvertis leidžia atskirti dvi pagrindines gyvenamujų namų grupes: senos statybos ir naujos, taip pat leidžia susidaryti nuomonę apie seniūnijoje esančių pastatų būklę ir socialinị gyventojų sluoksnị.

- $U_{4}$ - urbanistinès plètros objektų skaičius. Jis rodo naujų NT objektų statybos skaičiu seniūnijoje. Kuo šio rodiklio reikšmè didesnè, tuo didesnès privataus ir valstybinio kapitalo investicijos seniūnijoje.

- $U_{5}$ - atstumas iki miesto centro. Parodo faktinị atstumą nuo nagrinèjamos seniūnijos iki geometrinio miesto centro (centrinio pašto).

Socialinių rodiklių grupejje $C_{S}$ atrinkti svarbiausieji AT ankstyvieji vertinimo rodikliai:

- $S_{1}$ - nedarbo lygis. Jis reprezentuoja santykinį seniūnijos gyventojų pragyvenimo lygị, vidutini gyventojų amžiu ir socialinès gerovès laipsnį, lyginant su kitomis seniūnijomis.

- $S_{2}$ - skurstantys gyventojai. Šis rodiklis nusako turtinę seniūnijos gyventojų padèti, pragyvenimo lygi ir gyvenimo kokybès skirtumus atskirose seniūnijose.

- $S_{3}$ - vidutinès namų ūkio pajamos. Parodo darbingos gyventojų dalies ekonomini pajègumą. Šio rodiklio reikšmė taip pat išryškina darbo vietų sklaidą nagrinèjamoje ir aplinkinèse seniūnijose.

- $S_{4}$ - nusikalstamumas. Jis atskleidžia viešojo saugumo lygi seniūnijoje. Kuo didesnè šio rodiklio svorio reikšmè, tuo nepatrauklesnè socialinė aplinka vyrauja seniūnijoje.

- $S_{5}$ - švietimo ir ikimokyklinio ugdymo ịstaigų skaičius. Šis rodiklis apibrěžia seniūnijos švietimo sistemos būklę, prieinamumą gyventojams.

Gamtinių rodiklių grupès $C_{N}$ atrinkti svarbiausieji AT ankstyvieji vertinimo rodikliai:

- $N_{1}$ - grunto užterštumas. Tai rodiklis, apibrèžiantis žemès, kurioje gali būti AT, užterštumą, nuodingujų medžiagų kiekị ir kt.

- $N_{2}$ - kietujų dalelių koncentracija. Tai vidutinè kietujų dalelių koncentracija ore nagrinèjamoje seniūnijoje. Šis veiksnys sukelia 
gyventojų sveikatos problemas, lemia blogesnę gyvenimo kokybę ir neplaningai išvystytą susisiekimo ar kitą inžinerinę infrastruktūrą.

- $N_{3}$ - žaliujų plotų kiekis. Šiuo rodikliu išreiškiamas visų tipų žaliujų plotų kiekis, tenkantis vienam seniūnijos gyventojui. Kuo šis dydis geresnis, tuo mažesnè oro tarša, patrauklesnè aplinka ir vyrauja geresnis mikroklimatas. Tokie plotai vertinami kaip privalumas vystant NT projektus.

- $N_{4}$ - transporto tarša. Tiesioginès transporto priemonių taršos masto rodiklis. Kuo didesnè šio rodiklio reikšmè, tuo esami transporto srautai prasčiau suplanuoti seniūnijos susisiekimo sistemoje.

Nustatyta, kad parengtas AT vertinimo rodiklių modelis atitinka ne tik Lietuvos, bet ir kitų anksčiau Sovietų Sajungos okupuotų šalių (pvz., Čekijos Respublika, Slovakija, Rumunija ir kt.) socialinį, ekonominị, istorinị, kultūrinị ir urbanistini klimatą, kuri savo darbuose nagrinèjo skirtingo laikotarpio mokslininkai (Dotzour 2002; Strenge, Chamberlain 1995; USEPA 1991; Rügner et al. 2006).

\subsubsection{Ekspertinio vertinimo išvados}

- Remiantis mokslinès literatūros analize atrinktų 48 AT ankstyvųjų rodiklių svarbą vertino po 10 kompetentingų ekonomikos, urbanistikos, statybos ir planavimo sričių ekspertai. Vertinimas vyko pagal 10 balų sistemą.

- Pagal skaičiavimus patikrinus ekspertų rodiklių vertinimo suderinamumą, galima teigti, kad vertinimai yra suderinti. Pratęsus skaičiavimus, nustatyti svarbumo rodikliai kiekvienam iš atskiros miesto aplinkos rodiklių. Tai leido nustatyti rodiklių hierarchiją grupèse.

- Žinant rodiklių hierarchiją ekonominès, socialinès, fizinès ir gamtinès miesto aplinkos grupèse, atrinkti 15 pačių svarbiausių AT ankstyvujjų rodiklių. Ekonominejje aplinkoje nustatyti šie svarbiausi: investicijos, žemès kaina, santykis tarp turto kainos teritoriniame administraciniame vienete ir gretimuose administraciniuose teritoriniuose vienetuose, NT vertè, erdvinis neatitikimas tarp darbuotojų ir darbo vietų. Svarbiausi socialinèje miesto aplinkoje yra šie: žmonių, gyvenančių žemiau skurdo ribos, procentas, ilgalaikis nedarbo lygis, namų, kuriuose gyvenama nuolat, ir parduodamų namų procentinis santykis, chuliganiški nusikaltimai, užfiksuoti tam tikru periodu, taip pat, lyginant su regiono statistika, faktinès vidutinès gyventojų pajamos. Užstatymo ir infrastruktūros aplinkoje nustatyti šie svarbiausi rodikliai: laisvų sklypų plotas, naujų statybos leidimų skaičius, pastatų pastatymo amžius, gyvenamieji objektai, kelių / tiltų sistemos žemiau standartinès būklès procentas. Svarbiausi gamtinèje aplinkoje esantys rodikliai: pavojingos atliekos / kitoks užterštumas, išmetamosios medžiagos iš vietinių 
pramonės ịmonių / gyvenamųjų namų, vandens užterštumo lygis, žaliujų plotų sklype procentas ir jų kokybė, transporto priemonių išmetamųjų teršalų lygis.

- Atliekant toliau pateiktus skaičiavimus, teorinis AT vertinimo rodiklių masyvas pakeistas alternatyviais rodikliais, kuriuos apibūdina surinkti ir skaitmenizuoti duomenys.

- Sudarytą rodiklių sistemą galima taikyti praktikoje kaip pagrindą vykdyti rodiklių duomenų monitoringą pagal jų kitimą.

- Taikant teritorij valdymo metodus, AT problema galètų būti išsprendžiama iš anksto nustatant ir numatant teritorijos potencialą tapti apleista pačiame anksčiausiame teritorijos gyvavimo ciklo etape.

\subsection{Erdvinè koreliacinė analizè, padedanti nustatyti priežastinį ryši tarp apleistų teritorijų vertinimo rodiklių ir jų apimties seniūnijose}

Norint apskaičiuoti koreliacinio ryšio tarp AT vertinimo rodiklių ir AT užimamo ploto kiekvienoje seniūnijoje (toliau - AT imtis), nepakanka suformuotos hierarchinès AT ankstyvujų rodiklių sistemos. Tam tikslui reikia ankščiau gautus rodiklių svorius panaudoti pagal autoriaus sukurtą algoritmą.

Metodo taikymo tikslas - nustatyti, kokie rodikliai tiesiogiai (teigiamai arba neigiamai) koreliuoja su AT plotu, tenkančiu vienam seniūnijos gyventojui.

\subsubsection{Erdvinès koreliacinès analizès modelis}

Darbe taikyta koreliacinė analizė rodo vyraujančio ryšio stiprumą tarp atrinktų AT ankstyvujų vertinimo rodiklių reikšmių ir AT plotų kiekvienoje Vilniaus miesto seniūnijoje $D_{i}$.

Koreliacijos koeficientas $R$ skaičiuotas tarp $i$-tojo rodiklio reikšmiu ir AT seniūnijoje $D_{i}$ plotų sumų (ha) eilučių (3.11 formulè). Teorinè koreliacinès analizès taikymo schema pavaizduota 3.3 paveiksle.

Apskaičiavus kiekvieno nagrinejjamo rodiklio $C_{i}$ dydžius $R_{i}$, gautas koreliacijos koeficientų reikšmių masyvas $R$. Ši imtis rodo, kad vienas rodiklis stipriau susijęs su AT apimtimis visoje Vilniaus miesto teritorijoje negu kitas. Taikant ši modeli rodiklio $C_{i}$ skaliarinès reikšmès gali būti absoliučiosios (nenormalizuotos), nes analizuojamas dviejų reikšmių masyvų absoliutusis koreliacinis tarpusavio ryšys. Toks skaičiavimo modelis leidžia nesunkiai ịvertinti miesto aplinkos rodiklio ryši su apleistų teritorijų kiekybiniais ir kokybiniais parametrais.

Kuo didesnis koreliacinis ryšys $R_{i}$, tuo didesnę ittaką rodiklio fizinès išraiškos pokyčiai miesto kontekste darys AT regeneraciniams procesams, socialinei, 
ekonominei ir ekologinei aplinkai. Apskaičiuoti rodiklių koreliacijų koeficientai gali būti vertinami kaip objektyvaus vertinimo būdu nustatyti svoriai.

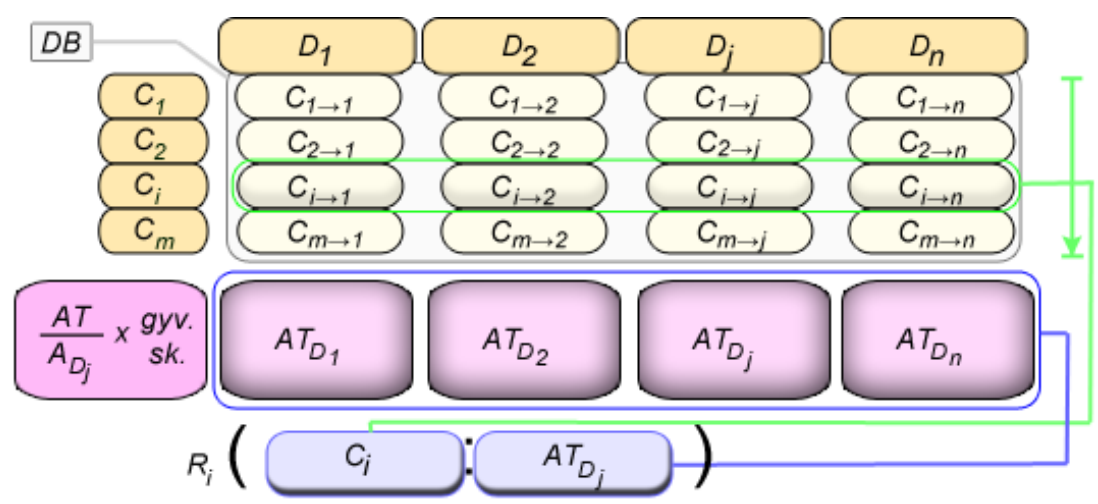

čia $n$ - seniūnijų skaičius (mūsų atveju - 20); $m$ - rodiklių skaičius

3.3 pav. Koreliacinès analizės taikymo tyrime principinè schema (sudaryta autoriaus)

Fig. 3.3. A principal scheme for correlation analysis applied for research purposes (created by author)

Apskaičiavus svorius toliau galima suformuoti prioritetinių rodiklių eilę pagal jų apskaičiuotą $R_{i}$ dydį. Siekiant apsaugoti ekologinę miesto aplinką, formuoti kompaktišką ir patrauklų miestą investicijoms pritraukti, didžiausias absoliučiąsias reikšmes $R_{i}$ igijusius rodiklius autorius rekomenduoja ịtraukti ị bendrujų ir specialiujų miesto planų bei kitų planavimo dokumentų rengimo procesus. Šie rodikliai kaip rekomendaciniai sprendiniai padètų formuoti ilgalaikę miesto sutvarkymo strategiją, atliekant ateities miesto vystymosi prognozes.

$$
R_{i}=\frac{\sum_{i=1}^{n}(X-\bar{X}) \times(Y-\bar{Y})}{\sqrt{\sum_{i=1}^{n}(X-\bar{X})^{2} \times \sum_{i=1}^{n}(Y-\bar{Y})^{2}}},
$$

čia $R$ - imties koreliacijos koeficientas; $X$ - nepriklausomojo kintamojo (nagrinèjamo rodiklio) reikšmé; $Y$ - priklausomojo (AT imtis) kintamojo reikšmè. $R$ aibès dydžiai sudaro bendraji koreliacijos koeficientų reikšmių masyvą $I$ $\left(R=\left[R_{1}, R_{2}, R_{i}, \ldots, R_{n}\right]\right)$.

Ištrauka iš naudojamos rodiklių duomenų bazès pateikta 3.4 lentelèje. 
3.4 lentelè. Ištrauka iš naudojamos rodiklių duomenų bazès (sudaryta autoriaus)

Table 3.4. The extract of the used criteria database (created by author)

\begin{tabular}{|c|c|c|c|c|c|c|c|c|c|c|c|c|}
\hline & $D_{1}$ & $D_{2}$ & $D_{3}$ & $D_{4}$ & $D_{5}$ & $D_{6}$ & $D_{7}$ & $D_{8}$ & $D_{9}$ & $D_{10}$ & $\ldots$ & $D_{20}$ \\
\hline$U_{3}$ & 45 & 33 & 31 & 44 & 34 & 67 & 53 & 50 & 49 & 38 & $\ldots$ & 65 \\
$U_{4}$ & 0,84 & 0,14 & 0,11 & 0,18 & 0,16 & 0,98 & 0,34 & 0,13 & 0,10 & 0,35 & $\ldots$ & 0,89 \\
$U_{2}$ & 7,98 & 0,69 & 0,49 & 0,46 & 1,15 & 0,60 & 7,02 & 12,87 & 30,66 & 0,69 & $\ldots$ & 4,02 \\
$U_{5}$ & 8,01 & 5,22 & 5,46 & 4,24 & 5,66 & 1,27 & 5,27 & 5,57 & 11,37 & 6,12 & $\ldots$ & 2,37 \\
$N_{2}$ & 22,27 & 18,73 & 15,50 & 18,93 & 26,53 & 54,70 & 23,43 & 12,40 & 28,80 & 30,67 & $\ldots$ & 31,00 \\
$N_{1}$ & 10,20 & 3,60 & 2,00 & 2,30 & 2,40 & 17,90 & 7,40 & 10,30 & 7,20 & 2,20 & $\ldots$ & 3,10 \\
\hline
\end{tabular}

Socialinių ir urbanistinių rodiklių skaitinès reikšmės, išskyrus $U_{3}$ ir $U_{5}$, yra normalizuotos pagal kiekvienos seniūnijos $D_{i}$ gyventojų skaičių.

\subsubsection{Erdvinès koreliacinès analizès rezultatai}

$R$ masyvo koreliacijos koeficientų reikšmès $R_{i}$ gali svyruoti nuo -1 iki +1 . Kuo artimesnè 1 šio koeficiento reikšmè, tuo stipresnè priklausomybè. Determinacijos koeficientu masyvo Det elementai $\operatorname{Det}_{i}\left(R_{i}\right.$ dydžio kvadratas) rodo kiekvieno rodiklio stiprumo lygi (Čekanavičius, Murauskas 2009). Kuo didesnè šio dydžio gautoji reikšmè, tuo stipresnis, nepaisant $R$ dydžio ženklo, ryšys su AT plotais (3.4 pav.).

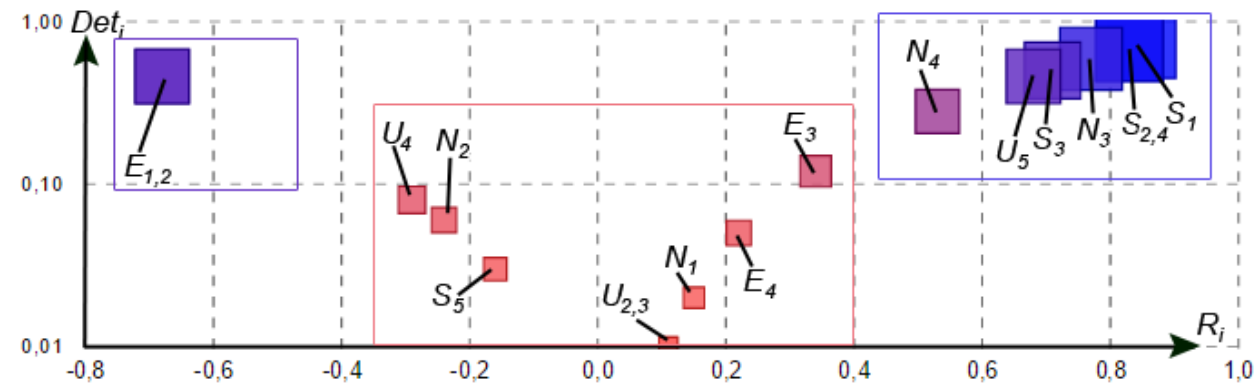

3.4 pav. Apskaičiuotos koreliacijų koeficientų reikšmès ( $R$ masyvas) ir determinacijos koeficientų (Det masyvas) reikšmès (sudaryta autoriaus)

Fig. 3.4. The calculated values of correlation ( $R$ array) and determination (Det array) coefficients (created by author) 
Tai sąlyginis dydis, padedantis analizuoti atskirų rodiklių reikšmes tarpusavyje. Skaičiavimai parodè, kad 13 iš 18 rodiklių būdinga teigiama priklausomybè tarp AT paplitimo.

Didžiausia teigiamoji priklausomybė tarp AT paplitimo ir atskirų rodiklių apskaičiuota nagrinèjant nedarbo lygị $\left(R_{i} \mid S_{1}=0,85\right)$, skurde gyvenančių gyventojų skaičiu $\left(R_{i} \mid S_{2}=0,83\right)$ ir nusikalstamumo apimtis $\left(R_{i} \mid S_{4}=0,83\right)$ atskirose seniūnijose. Ši reiškinị galima paaiškinti tuo, kad AT tam tikrais laiko tarpais vyrauja marginalinès bendruomenès atstovai, kurie priklauso žemesniam ir linkusiam nusikalsti socialiniam sluoksniui.

Tarp rodiklių, kuriems būdinga stipriausia teigiama priklausomybè, nustatytas urbanistinių rodiklių grupei $C_{U}$ priskiriamas dydis - nenaudojamos žemès plotai $\left(R_{i} \mid U_{1}=0,83\right)$.

Tai rodo, kad nepanaudoti miesto teritorijoje esantys žemès plotai gali būti vertinami kaip AT sklaidos katalizatoriai, t. y. nepanaudotos erdvès tam tikru spinduliu aplink formuoja nepatrauklią aplinką naujoms investicijoms į NT. Tai lètina naujų žemès paskirčių diegimą ir naujos NT statybos projektų ịgyvendinimą.

Ekonominių rodiklių grupei $C_{E}$ priskiriami dydžiai, kuriems būdinga stipriausia neigiamoji priklausomybè. Joms skirtos investicijos $\mathfrak{i}$ aplinką $\left(R_{i} \mid E_{1}=-0,68\right)$ ir statybos kaina $\left(R_{i} \mid E_{2}=-0,68\right)$. Ši atvirkštinè priklausomybè patvirtina faktą, kad tikslingai nukreiptų investicijų (ES, privačios, valstybès ar kitos lëšos) poveikis aplinkai yra esminis. Prie šio reiškinio ypač prisideda PPP.

Kiekvienai grupei priskiriamų rodiklių prioritetinès eilutès pagal nustatytą $R_{i}\left[C_{E}, C_{U}, C_{S}, C_{N}\right]$ koeficiento rangą pateiktos 3.5 lentelëje.

3.5 lentelè. Nustatyti rodiklių rangai pagal apskaičiuotą koeficientą $R_{i}$

Table 3.5. The determined ranks of criteria according to calculated coefficient $R_{i}$

\begin{tabular}{|c|c|c|c|c|c|c|c|}
\hline \multicolumn{8}{|c|}{ Rodiklių grupès } \\
\hline \multicolumn{2}{|r|}{$C_{E}$} & \multicolumn{2}{|r|}{$C_{U}$} & \multicolumn{2}{|r|}{$C_{S}$} & \multicolumn{2}{|r|}{$C_{E}$} \\
\hline$R n$ & Rodiklis & & Rodiklis & $R n$ & Rodiklis & $R n$ & Rodiklis \\
\hline 1. & $E_{1}(R=-0,68)$ & 1. & $U_{1}(R=0,83)$ & 1. & $S_{1}(R=0,85)$ & 1. & $N_{3}(R=0,77)$ \\
\hline 2. & $E_{2}(R=-0,68)$ & 2. & $U_{5}(R=0,68)$ & 2. & $S_{2}(R=0,83)$ & 2. & $N_{4}(R=0,53)$ \\
\hline 3. & $E_{3}(R=0,34)$ & 3. & $U_{4}(R=-0,29)$ & 3. & $S_{4}(R=0,83)$ & 3. & $N_{2}(R=-0,24)$ \\
\hline \multirow{2}{*}{4.} & \multirow{2}{*}{$E_{4}(R=0,22)$} & & $U_{2}(R=0,11)$ & 4. & $S_{3}(R=0,71)$ & \multirow{2}{*}{4.} & \multirow{2}{*}{$N_{1}(R=0,15)$} \\
\hline & & & $U_{3}(R=0,11)$ & 5. & $S_{5}(R=-0,16)$ & & \\
\hline
\end{tabular}

Gauti rezultatai parodè, kad yra skaliariniais dydžiais apibrèžiamas priežasčių ir pasekmių ryšys tarp miestuose esančių AT ir miesto fizinę, socialinę, ekonominę bei ekologinę aplinką apibūdinančių rodiklių kiekvienoje Vilniaus seniūnijoje $D_{i}$. Kiekvienai rodikliu grupei priskirtas rangas $R_{n}$ pagal apskaičiuotą vidutinị determinacijos koeficientą Det $_{i}$ kiekvienai rodiklių grupei $C$ (3.5 pav.). 
Iš 3.5 paveikslo matyti, kad labiausiai AT sklaidą seniūnijose $D_{i}$ lemia socialiniai rodikliai $\left(\right.$ Det $\left._{\text {vid,CS. }}=0,526\right)$. Ekonominiu rodiklių grupeje stipriausiu priežastiniu ryšiu pasižymi rodikliai, apibrěžiantys investicijas ị aplinką $\left(E_{1}\right.$, $R=-0,68)$ ir statybų kainą seniūnijoje $\left(E_{2}, R=-0,68\right)$. Kitose rodiklių grupèse stipriausiu priežastiniu ryšiu pasižymi tos Vilniaus miesto seniūnijos $D_{i}$, kuriose vyrauja didžiausi nenaudojamos žemės plotai $\left(U_{1}, R=0,83\right)$, didžiausias nedarbo lygis (pagal deklaruotą gyventojų gyvenamają vietą, $\left.S_{1}, R=0,85\right)$ ir didžiausias Žaliujų plotų hektaras, tenkantis vienam seniūnijos $D$ gyventojui $\left(N_{3}, R=0,77\right)$.

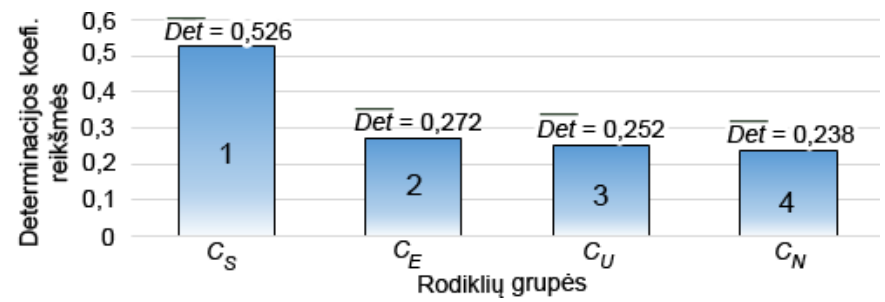

3.5. pav. Atskirų rodiklių grupių apskaičiuotos vidutinès dydžio $D e t_{i}$ reikšmès (sudaryta autoriaus)

Fig. 3.5. The calculated average values of $D_{e t i}$ values for each group of criteria (created by author)

3.5 lentelèje pateikti analizès rezultatai parodè, kad silpniausias priežastinis ryšys tarp AT kiekio seniūnijose $D$ ir objektyviųų vertinimo rodiklių vyrauja tose seniūnijose, kuriose dominuoja darbo vietų stygius / perteklius $\left(E_{4}, R=0,22\right)$, seniausieji miesto pastatai $\left(U_{3}, \quad R=0,11\right)$, nepakankamas švietimo ir ikimokyklinio ugdymo ịstaigų skaičius $\left(S_{5}, R=-0,16\right)$ ir didžiausias grunto užterštumas $\left(N_{1}, R=0,15\right)$.

\subsection{Apleistu teritorijụ paskirties keitimo scenariju vertinimas}

Šiame tyrime DSPM taikyti siekiant nustatyti tinkamiausią AT pertvarkymo scenarijų $T_{i}$ pagal dominuojančios vietinès miesto aplinkos savybes, kurias apibūdina atrinkti rodikliai. Nustatytas santykinis rodiklių svoris kiekvienam AT pertvarkymo scenarijui $T_{i}$. Darbo rezultatai aprašyti tarptautiniame mokslo žurnale (Burinskienè et al. 2017).

Sudarius hierarchiškai apibrèžtą ir kiekybinius ịverčius turinčią AT vertinimo rodiklių sistemą $C$ bei siekiant nustatyti, kokios rodiklių grupès turi didžiausią įtaką priimti sprendimą dèl konkretaus AT paskirties keitimo scenarijaus $T_{i}$ 
igyvendinimo, patogu nustatyti kiekvienos grupès rodiklių $C_{E, U, S, N}$ savuosius svorius, kai kiekvienos rodiklių grupès elementų yra ne daugiau kaip 5.

Atliekant AT rodiklių vertinimą, DSPM taikytas ekspertinio vertinimo būdas, kuriam 3.2.1 poskyryje aprašyti reikalavimai. Ekspertai buvo paprašyti užpildyti klausimų formas, kuriose jie turejjo nurodyti skirtingų rodiklių svorius procentine išraiška. Kiekvienos rodiklių grupès $C_{E, U, S, N}$ vertinimo suma lygi $100 \%$. Iš viso ị tyrimą buvo ịtraukta 12 ekspertų.

Ekspertų apklausai pasirinkta „nominaliu grupių“ Delphi metodika (Green et al. 2007; Rowe et al. 1999). Tai sisteminis sociologinis metodas, kuris nuo 20 a. 7-ojo dešimtmečio pradètas taikyti ekonomineje, sveikatos ir švietimo srityje. Nepaisant kai kurių trūkumų, lyginant metodą su kitais, pvz., UTA (Jacquet-Lagreze, Siskos 1982) ar Likerto skalès (Nishisato 2004), Delphi metodas gana plačiai taikomas ịvairiose prognozavimo srityse ir struktūriniams tyrimams (Melander 2018; Kilgour et al. 2010; Vidal et al. 2011). Šiame tyrime šis metodas pasirinktas dèl nuoseklaus skaičiavimo ir gero pritaikymo praktikoje (Habibi et al. 2015; Hwang, Lin 1987).

\subsubsection{Neparametrinè statistinè analizè}

Norint įvertinti ekspertų suderinamumo lygi, pagal ekspertų suteiktus svorius rodikliams suteikti rangai ir taikyta Kendalo teorija (Kendall 1975). Skirtingas AT paskirties keitimo scenarijus $T_{i}$ turi būti igyvendinamas esant skirtingiems miesto plètros prioritetams, ekonominei, socialinei ir kitokio pobūdžio vietinio lygmens miesto aplinkai. Esant šiai prielaidai, apskaičiuoti skirtingi rodiklių grupių $C_{E, U, S, N}$ ir skirtingų rodiklių $C_{i}$ grupès viduje esantys svoriai kiekvienam AT paskirties keitimo atvejui $T_{i}$. Kriterijams suteikti rangai žymimi $e_{i k}$ (3.12 formulè), čia $i=1,2, \ldots, m$ yra rodiklio indeksas. Tyrimo atveju $m$ lygus 4 arba $5 ; k=1,2, \ldots, k$ yra vertintojo (eksperto) indeksas; $r$ - ekspertu skaičius, kuris tyrimo atveju yra 12 . Konkordancijos koeficientas $W$, taip pat chi kvadrato suderinamumo koeficientas naudoti norint apskaičiuoti konkordancijos koeficientą, priklausanti nuo ekspertų suteiktų rangų $e_{i k}$ standartinès deviacijos, pakeltos kvadratu.

$$
e_{i}=\sum_{k=1}^{r} e_{i k},
$$

Jis išplaukia iš rangų sumų vidurkio:

$$
\bar{e}=\frac{\sum_{i=1}^{m} e_{i}}{m} .
$$

Taigi konkordancijos koeficientas $W$ lygus sumos $S$ (3.14 formulè) ir didžiausios šios sumos $S$ ( $\left.S_{\max }\right)$ (3.15 formulè) santykiui. 


$$
\begin{gathered}
S=\sum_{i=1}^{m}\left(e_{i}-\bar{e}\right)^{2} ; \\
S_{\max }=\frac{r^{2} \times m \times\left(m^{2}-1\right)}{12} .
\end{gathered}
$$

Taigi, atsižvelgiant i (3.14) ir (3.15) formulèse pateiktas išraiškas, konkordancijos koeficientas $W$ gali būti apskaičiuojamas pagal (3.16) formulę.

$$
W=\frac{S}{S_{\max }}=\frac{12 \times S}{r^{2} \times m \times\left(m^{2}-1\right)} \cdot
$$

Chi kvadrato suderinamumo kriterijus apskaičiuojamas pagal (3.17) formulę.

$$
\chi^{2}=W \times r \times(m-1)=\frac{12 \times S}{r \times m \times(m+1)} .
$$

Laisvès laipsnių skaičius nustatomas taikant lygybę $v=m-1$. Atliekant skaičiavimus, taikytas reikšmingumo lygis $\alpha=0,05$. Tokiu būdu nustatyti vienodas reikšmes turintys rangai tarp visų šešių rodiklių svorių rinkinių kiekvienam AT paskirties keitimo scenarijui $T_{i}$. Nustatyti dvi tokias pačias reikšmes turintys rangai visuose rinkiniuose. Tais atvejais, kai rangai vienodi, $W$ gali būti apskaičiuojamas pagal (3.18) formulę (Kendall 1990).

$$
W=\frac{12 \times S}{r^{2} \times m \times\left(m^{2}-1\right)-r \times \sum_{\varphi}\left(t_{\phi}^{3}-t_{\varphi}\right)},
$$

čia $\varphi$ - vienodų rangų skaičius; $t_{\varphi}$ - vienodų rangų skaičių tarp $\varphi$ aibès.

Suderinamumo kriterijaus, kurị išreiškia ekspertų $k$ vertinimų konkordancijos koeficientas kiekvieno nagrinëjamo AT paskirties keitimo scenarijaus $T_{1-6}$ atveju, vertinant visus AT vertinimo rodiklius $C_{i}$ ir kiekvieną AT vertinimo rodiklių grupę $C_{E, U, S, N}$ atskirai, skaičiavimai pateikti $\mathrm{C}$ priede.

Igyvendinus pirmajji Delphi etapą, gauti šešių rezultatų rinkiniai kiekvieno AT paskirties keitimo scenarijaus $T_{1-6}$ atvejui, kuriuose nustatytos ekspertuc nuomonés yra nesuderinamos. Mūsų atveju labiausiai besiskiriantys atvejai pateikti tiems patiems ekspertams. Nauji rezultatai su kita atsakymų dalimi perskaičiuojami antrajame Delphi tyrimo (apklausos) etape. Tokiu būdu galima atlikti nesuderintos ekspertų nuomonès korektūras (C priedo C.5-C.6 lentelès).

Ivykdžius pirmojo Delphi metodo etapo koregavimo pirmą raundą (C priedo C.7 lentelè) ir tęsiant apklausą su atrinktais ekspertais, pirmojo etapo rezultatų nesuderintos nuomonès reikšmingoji tyrimo dalis tapo suderinama. Atsižvelgiant $i$ koreguotus ekspertų vertinimus, perskaičiuotos konkordancijos koeficiento $W$, chi 
kvadrato suderinamumo kriterijaus reikšmès rodiklių grupėms $C_{E, U, S, N}$ ir kiekvienam nagrinèjamam AT paskirties keitimo scenarijui $T_{1-6}$ (3.6 lentelè).

3.6 lentelè. Perskaičiuotos konkordancijos koeficiento $W$ reikšmès ir testuojamo duomenų rinkinio kiekvienai rodiklių grupei reikšmès (po korekcijų)

Table 3.6. The adjusted values of Kendall's concordance coefficient $W$ and the values of the tested dataset for each group of criteria (after corrections)

\begin{tabular}{|c|c|c|c|c|c|}
\hline \multirow{2}{*}{ Rodiklių grupès } & \multicolumn{5}{|c|}{ Statistiniai parametrai } \\
\hline & $W$ & $\chi^{2}$ & $m$ & $\chi_{c r}^{2}$ & $\chi^{2}-\chi_{c r}^{2}$ \\
\hline 1 & 2 & 3 & 4 & 5 & 6 \\
\hline \multicolumn{6}{|c|}{ Scenarijus $T_{1}$} \\
\hline$C_{E}$ & $0,821 *$ & $29,56 *$ & 4 & 7,81 & 21,75 \\
\hline$C_{U}$ & 0,361 & 17,33 & 5 & 9,49 & 7,84 \\
\hline$C_{S}$ & 0,314 & 15,08 & 5 & 9,49 & 5,59 \\
\hline$C_{E}$ & 0,337 & 12,13 & 4 & 7,81 & 4,32 \\
\hline Vidutinès reikšmės: & 0,330 & 11,87 & 4 & 7,81 & 4,06 \\
\hline \multicolumn{6}{|c|}{ Scenarijus $T_{2}$} \\
\hline$C_{E}$ & 0,767 & 27,60 & 4 & 7,81 & 19,79 \\
\hline$C_{U}$ & $0,301 *$ & $14,43 *$ & 5 & 9,49 & 4,94 \\
\hline$C_{S}$ & 0,326 & 15,67 & 5 & 9,49 & 6,18 \\
\hline$C_{E}$ & 0,274 & 9,87 & 4 & 7,81 & 2,06 \\
\hline Vidutinės reikšmės: & 0,815 & 29,33 & 4 & 7,81 & 21,52 \\
\hline \multicolumn{6}{|c|}{ Scenarijus $T_{3}$} \\
\hline$C_{E}$ & 0,633 & 22,80 & 4 & 7,81 & 14,99 \\
\hline$C_{U}$ & 0,443 & 21,25 & 5 & 9,49 & 11,76 \\
\hline$C_{S}$ & $0,417 *$ & $20,00^{*}$ & 5 & 9,49 & 10,51 \\
\hline$C_{E}$ & 0,715 & 25,73 & 4 & 7,81 & 17,92 \\
\hline Vidutinès reikšmės: & $0,550^{*}$ & $19,79 *$ & 4 & 7,81 & 11,98 \\
\hline \multicolumn{6}{|c|}{ Scenarijus $T_{4}$} \\
\hline$C_{E}$ & 0,744 & 26,80 & 4 & 7,81 & 18,99 \\
\hline$C_{U}$ & $0,663^{*}$ & $31,81 *$ & 5 & 9,49 & 22,32 \\
\hline$C_{S}$ & 0,328 & 15,75 & 5 & 9,49 & 6,26 \\
\hline$C_{E}$ & 0,604 & 21,73 & 4 & 7,81 & 13,92 \\
\hline Vidutinès reikšmės: & 0,456 & 16,40 & 4 & 7,81 & 8,59 \\
\hline \multicolumn{6}{|c|}{ Scenarijus $T_{5}$} \\
\hline$C_{E}$ & 0,685 & 24,67 & 4 & 7,81 & 16,86 \\
\hline$C_{U}$ & $0,263^{*}$ & $12,67 *$ & 5 & 9,49 & 3,18 \\
\hline$C_{S}$ & 0,344 & 16,50 & 5 & 9,49 & 7,01 \\
\hline$C_{E}$ & 0,337 & 12,13 & 4 & 7,81 & 4,32 \\
\hline Vidutinės reikšmės: & 0,626 & 22,53 & 4 & 7,81 & 14,72 \\
\hline
\end{tabular}


3.6 lentelès pabaiga

\begin{tabular}{|l|c|c|c|c|c|}
\hline \multicolumn{7}{|c|}{1} & 2 & 3 & 4 & 5 & 6 \\
\hline \multicolumn{7}{|c|}{ Scenarijus $T_{6}$} \\
\hline$C_{E}$ & 0,315 & 11,33 & 4 & 7,81 & 3,52 \\
\hline$C_{U}$ & 0,587 & 28,17 & 5 & 9,49 & 18,68 \\
\hline$C_{S}$ & 0,198 & 9,50 & 5 & 9,49 & 0,01 \\
\hline$C_{E}$ & 0,332 & 11,97 & 4 & 7,81 & 4,16 \\
\hline Rodiklių grupè: & 0,278 & 10,00 & 4 & 7,81 & 2,19 \\
\hline
\end{tabular}

Atlikti neparametrinès analizès skaičiavimais pagerintos 5 ekspertinio vertinimo suderinamumo kriterijaus chi kvadrato reikšmes. Taikant ši metodą labiausiai pagerintos suderinamumo kriterijaus reikšmès urbanistiniams rodikliams $C_{U}$ (reikšmès pasikeite 3 AT paskirties keitimo scenarijų atvejais). Irodžius, kad eskpertų nuomonès suderintis, galima apskaičiuoti rodiklių svorius.

Kiekvieno AT vertinimo rodiklio $C_{i}$ svoriui nustatyti, žinant rodiklių grupès $C_{E, U, S, N}$ svorius ir kiekvieno rodiklio $C_{i}$ grupès viduje svorius, pasiūlytas Podviezko (2015) metodas. Jis gali būti taikomas tais atvejais, kai naudojamos hierarchinès rodiklių struktūros. Skirtingų AT rodiklių grupių svoriai padauginti iš rodiklių $C_{i}$ svorių rodiklių grupès viduje pagal (3.19) formulę:

$$
\omega_{i}=\omega_{i_{k}} \times \omega_{k}
$$

čia $k$-rodiklių grupès indeksas; $i_{k}$-rodiklio indeksas $C_{k}$ rodiklių grupejje.

Taikant (3.19) formulę toliau skaičiuojami AT svoriai skirtingais paskirties keitimo scenarijų $T_{i}$ iggvendinimo atvejais.

\subsubsection{Svarbiausių rodiklių nustatymas skirtingų apleistų teritorijų paskirties keitimo scenariju atvejais}

Kiekvienam AT paskirties keitimo scenarijui $T_{1-6}$ rodiklių grupių $C_{E, U, S, N}$ svoriai $\omega_{i}$ apskaičiuoti taikant (3.19) formulę (3.6 pav.). Tokiu būdu galima apskaičiuoti kiekvienos AT rodiklių grupès svorị kiekvieno nagrinèjamo AT paskirties keitimo scenarijaus $T_{1-6}$ atveju.

3.6 paveiksle pateikti vertinimo rezultatai parodè, kad apytikriai vienodai svarbios visos rodiklių grupès atliekant AT paskirties keitimą ì žaliają zoną $\left(T_{1}: C_{E}=20,25, C_{U}=26,5, C_{S}=23,0, C_{N}=30,25, s=4,33\right) .26 C_{E}=22,17$, $\left.C_{U}=24,08, C_{S}=34,08, C_{N}=19,5, s=6,36\right)$.

Šie rezultatai išryškina poreikị plètoti žaliąsias erdves miesto zonose tolygiai, nepriklausomai nuo vyraujančios teritorijos ar jų grupių funkcinès paskirties. Pramoninès paskirties teritorijose žaliujų zonų plètra prisideda prie urboekologinès teritorijų funkcijos užtikrinimo; gyvenamosiose zonose - gyventojų laisvalaikio 
praleidimui tinkamos erdvès sukūrimo, teritorinès bendruomenès aplinkos identiteto formavimo mažosios architektūros elementais ir kt.
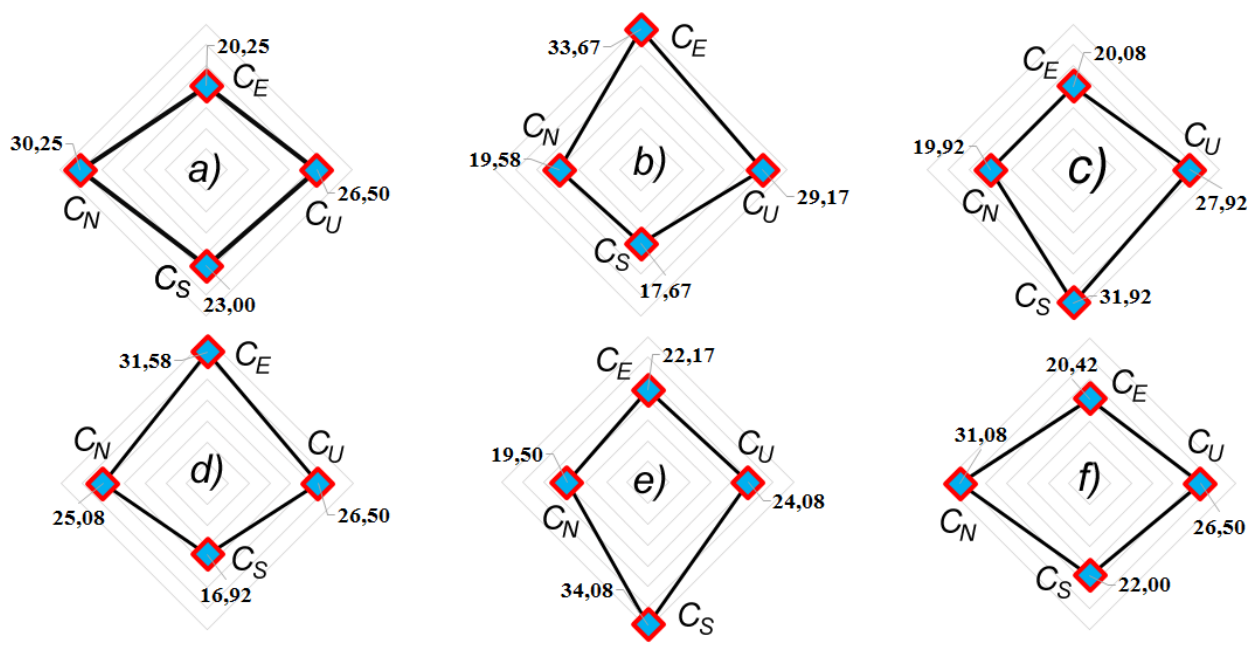

3.6 pav. Rodiklių grupių $C_{E, U, S, N}$ apskaičiuoti svoriai $\omega_{i}$ paskirties keitimo scenariju atvejais: a) $T_{1}$; b) $T_{2}$; c) $T_{3}$; d) $T_{4}$; e) $T_{5}$; f) $T_{6} T_{1-6}, \%$ (sudaryta autoriaus) Fig. 3.6. The calculated weights of the groups of criteria $C_{E, U, S, N}$ for each brownfield redevelopment scenario: a) $T_{1}$; b) $T_{2}$; c) $T_{3}$; d) $T_{4}$; e) $T_{5}$; f) $T_{6} T_{1-6}, \%$ (created by author)

Netolygiausias rodiklių grupių svorių pasiskirstymas, lemiantis sprendimų prièmimą dèl AT paskirties keitimo nustatytas paskirties keitimo ị gyvenamąsias zonas atveju $\left(T_{5}\right)$. Šis rezultatas kelia prielaidą, kad gyvenamų zonų plètra mieste turi būti griežtai vertinama su kitos paskirties (pvz. žaliujų zonų) plètros sprendiniais.

Siekiant detalizuoti sprendimu priemimo sprendinius smulkesnio teritorinio vieneto lygmenyje, apskaičiuoti rodiklių svoriai $\omega \%$, išreikšti procentine išraiška, kiekvienos AT vertinimo rodiklių grupès viduje ir pateikti 3.7 lentelèje.

Nagrinejjant AT vertinimo rodiklius atskirai bendruoju atveju, nustatyta, kad didžiausią bendrają įtaką ${ }^{4}$ sprendimų priemimui dèl AT paskirties keitimo daro investicijos ì teritoriją $\left(E_{l}=32,15 \%\right)$, žaliujų plotų kiekis $\left(N_{3}=27,96 \%\right)$, vidutinè statybos kaina ir kaštai $\left(E_{2}=27,17 \%\right)$ ir kietujų dalelių koncentracija ore $\left(N_{2}=26,86 \%\right)$. 3.7 lenteleje apskaičiuotų duomenu matrica naudojama tolimesniuose skaičiavimuose taikant DSPM.

${ }^{4}$ Apskaičiuojamas rodiklio svorio, išreikšto procentine išraiška, $\omega \%$ aritmetinis vidurkis visų AT paskirties keitimo scenarijų atvejais. Gaunamas reikšmių masyvas, sudarantis sąlygas palyginti skirting rodiklių vidutinius svorius bendruoju atveju. 
3.7 lentelè. Apskaičiuoti rodiklių svoriai kiekvienoje rodiklių grupejje kiekvienu nagrinejjamu apleistos teritorijos paskirties keitimo scenarijaus atveju $T_{1-6}$ (sudaryta autoriaus)

Table 3.7. The calculated weights of individual criteria for each brownfield scenario $T_{1-6}$ in each group of criteria, \% (created by author)

\begin{tabular}{|c|c|c|c|c|c|c|}
\hline \multirow{2}{*}{$\begin{array}{l}\text { Rodiklių } \\
\text { grupės }\end{array}$} & \multicolumn{6}{|c|}{ Paskirties keitimo scenarijai $T$} \\
\hline & $T_{1}$ & $T_{2}$ & $T_{3}$ & $T_{4}$ & $T_{5}$ & $T_{6}$ \\
\hline$E_{1}$ & 34,33 & 33,25 & 33,08 & 30,50 & 29,83 & 31,92 \\
\hline$E_{2}$ & 28,42 & 29,42 & 27,25 & 23,75 & 30,67 & 23,50 \\
\hline$E_{3}$ & 18,58 & 16,50 & 21,08 & 16,67 & 18,92 & 20,08 \\
\hline \multirow[t]{2}{*}{$E_{4}$} & 18,67 & 20,67 & 18,67 & 28,92 & 20,42 & 24,50 \\
\hline & $\Sigma=100 \%$ & $\Sigma=100 \%$ & $\Sigma=100 \%$ & $\Sigma=100 \%$ & $\Sigma=100 \%$ & $\Sigma=100 \%$ \\
\hline$U_{1}$ & 22,75 & 21,25 & 27,58 & 28,83 & 14,50 & 30,92 \\
\hline$U_{2}$ & 13,92 & 11,75 & 22,33 & 12,67 & 23,67 & 14,75 \\
\hline$U_{3}$ & 20,58 & 18,92 & 17,33 & 17,92 & 21,58 & 18,00 \\
\hline$U_{4}$ & 17,25 & 25,42 & 14,50 & 23,75 & 20,33 & 22,17 \\
\hline \multirow[t]{2}{*}{$U_{5}$} & 27,75 & 23,00 & 18,25 & 16,83 & 20,17 & 14,17 \\
\hline & $\Sigma=100 \%$ & $\Sigma=100 \%$ & $\Sigma=100 \%$ & $\Sigma=100 \%$ & $\Sigma=100 \%$ & $\Sigma=100 \%$ \\
\hline$S_{1}$ & 15,00 & 18,17 & 16,50 & 26,42 & 17,42 & 15,25 \\
\hline$S_{2}$ & 18,42 & 19,83 & 15,08 & 20,92 & 18,42 & 21,42 \\
\hline$S_{3}$ & 17,17 & 24,83 & 17,67 & 21,08 & 20,92 & 16,00 \\
\hline$S_{4}$ & 25,17 & 22,67 & 25,92 & 17,00 & 16,58 & 23,17 \\
\hline \multirow[t]{2}{*}{$S_{5}$} & 24,42 & 14,58 & 24,75 & 14,42 & 26,58 & 24,33 \\
\hline & $\Sigma=100 \%$ & $\Sigma=100 \%$ & $\Sigma=100 \%$ & $\Sigma=100 \%$ & $\Sigma=100 \%$ & $\Sigma=100 \%$ \\
\hline$N_{1}$ & 20,00 & 18,92 & 18,00 & 30,92 & 17,17 & 22,00 \\
\hline$N_{2}$ & 19,33 & 28,75 & 31,92 & 29,33 & 30,83 & 20,83 \\
\hline$N_{3}$ & 29,50 & 29,67 & 30,67 & 18,92 & 26,08 & 32,92 \\
\hline \multirow[t]{2}{*}{$N_{4}$} & 31,25 & 22,67 & 19,42 & 20,83 & 25,75 & 24,33 \\
\hline & $\Sigma=100 \%$ & $\Sigma=100 \%$ & $\Sigma=100 \%$ & $\Sigma=100 \%$ & $\Sigma=100 \%$ & $\Sigma=100 \%$ \\
\hline
\end{tabular}

Skirtingų AT rodiklių $C_{i}$ svorių nepriklausomos reikšmès $\omega$ skirtingu AT paskirties keitimo scenarijaus $T_{1-6}$ atveju apskaičiuotos laikantis 3.4.1-3.4.3 poskyriuose aprašytos metodologijos. Siekiant tarpusavyje palyginti 
rodiklių svarbą kiekvienu scenarijaus atveju $T_{i}$, buvo apskaičiuotos reikšmès, grafiškai pavaizduotos 3.7 paveiksle. Šie skaičiavimai detalizuoja 3.6 paveiksle pateiktus apskaičiuotus atskirų rodiklių svorius skirtingais AT paskirties keitimo scenarijų atvejais ir gali būti taikomi rengiant teritorijų planavimo sprendinius vietovès lygmenyje.
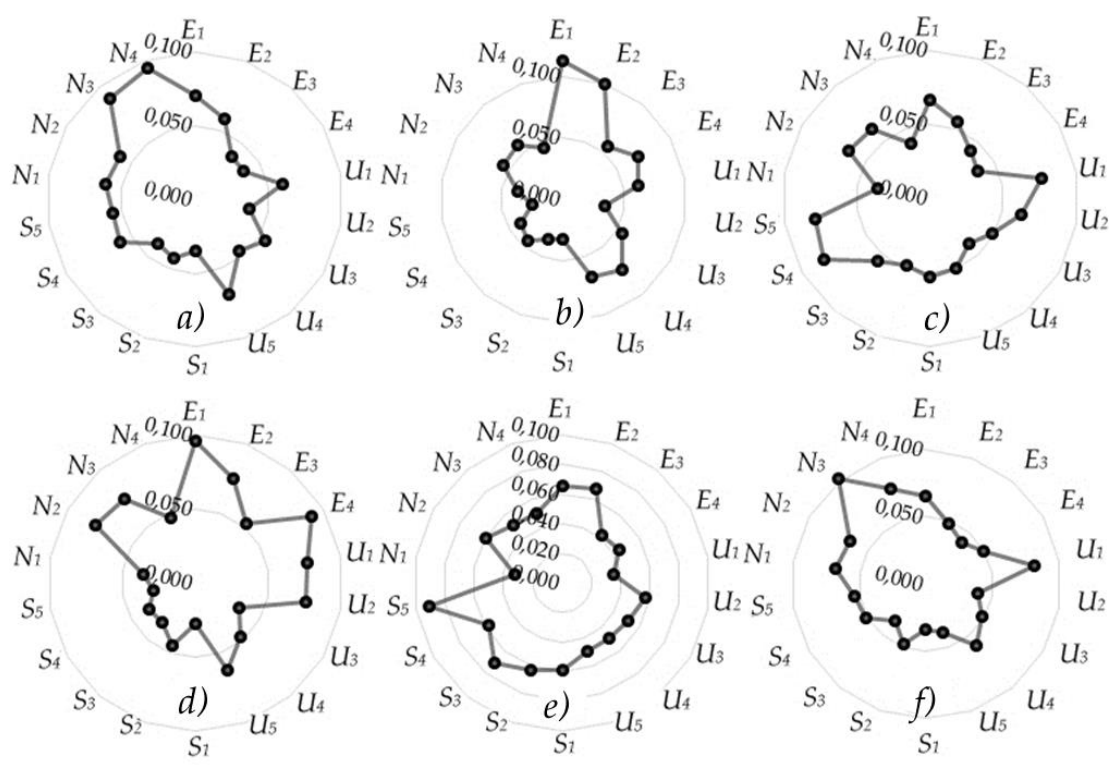

3.7 pav. Savieji apleistų teritorijų vertinimo rodiklių svoriai $\omega$ skirtingais paskirties keitimo atvejais: a) $T_{1}$; b) $T_{2}$; c) $T_{3}$; d) $T_{4}$; e) $T_{5}$; f) $T_{6}$ (sudaryta autoriaus)

Fig. 3.7. The weights of individual criteria for each brownfield redevelopment scenario: a) $T_{1}$; b) $T_{2}$; c) $T_{3}$; d) $T_{4}$; e) $T_{5}$; f) $T_{6}$ (created by author)

Iš 3.7 paveiksle pateiktų duomenų matyti, kad, atliekant strateginị miesto TP skirtingomis plètros kryptimis, jos efektyvumą ir pridètinę miesto vertę lemia skirtingų AT vertinimo rodiklių rinkiniai.

\subsubsection{Gautų rezultatų apžvalga ir vertinimas}

Gauti rezultatai išryškina šias AT antrinio naudojimo, pakeitus paskirtį, gaires:

- didžiausią įtaką AT paskirties keitimo ị žaliają erdvę $\left(T_{1}\right)$ sprendimams priimti turi ekologinès grupès rodikliai. Didžiausia ịtaka nustatyta žaliuosius plotus $N_{3}\left(\omega_{C N, 3}=0,089\right)$ ir transporto taršos lygi $N_{4}$ $\left(\omega_{C N, 4}=0,095\right)$ išreiškiantiems rodikliams; 
- didžiausią itaką AT paskirties keitimo i komercinę erdvę $\left(T_{2}\right)$ sprendimams priimti turi ekonominès grupès rodikliai $C_{E}$. Tarp jų didžiausia įtaka būdinga išreikštų rodiklių investicijoms į seniūnijos aplinką $E_{1}\left(\omega_{E, 1}=0,112\right)$ ir vietos statybos kainą $E_{2}\left(\omega_{E, 2}=0,099\right)$;

- didžiausią įtaką AT paskirties keitimo i sporto aikštynus ir aktyvaus laisvalaikio zonas $\left(T_{3}\right)$ sprendimams priimti turi socialinès ir urbanistinès grupès rodikliai. Didžiausią poveikị daro nusikalstamumą $S_{4}\left(\omega_{S, 4}=0,083\right)$, švietimo ir ikimokyklinio ugdymo skaičių seniūnijose $S_{5}\left(\omega_{S, 5}=0,079\right)$ bei nenaudojamus žemès plotus $U_{1}\left(\omega_{U, 1}=0,076\right)$ išreiškiantys rodikliai;

- didžiausią ịtaką AT paskirties keitimo i pramonines zonas $\left(T_{4}\right)$ sprendimams priimti turi beveik visi grupių rodikliai, išskyrus socialinę grupę. Tarp dominuojančių grupių didžiausią poveikị turi investicijas $\mathfrak{i}$ seniūnijos infrastruktūrą $E_{1}\left(\omega_{E, 1}=0,096\right)$, darbo vietų skaičių $E_{4}$ $\left(\omega_{E, 4}=0,091\right)$, gyvenamujjų objektų skaičių $U_{2}\left(\omega_{U, 2}=0,076\right)$, atstumą iki miesto centro $U_{5}\left(\omega_{U, 5}=0,063\right)$ ir kietujų dalelių koncentraciją ore $N_{2}$ $\left(\omega_{N, 2}=0,078\right)$ išreiškiantys rodikliai;

- didžiausią įtaką AT paskirties keitimo i gyvenamąsias zonas $\left(T_{5}\right)$ sprendimams priimti turi socialinès grupès rodikliai $C_{S}$. Čia didžiausią poveiki turi $S_{5}\left(\omega_{S, 5}=0,091\right)$ rodiklis, nurodantis švietimo ir vaikų priežiūros ịstaigu prieinamumą;

- didžiausią įtaką sprendimams AT palikti kaip miesto rezervą ateities reikmèms $\left(T_{6}\right)$ turi gamtiniai ir urbanistiniai rodikliai $\left(C_{N}\right.$ ir $\left.C_{U}\right)$. Tarp jų didžiausia ịtaka priskiriama žaliujų plotų kiekį $N_{3}\left(\omega_{N, 3}=0,102\right)$ ir nenaudojamų žemès plotų kiekị $U_{1}\left(\omega_{U, 1}=0,082\right)$ nusakantiems rodikliams.

Rezultatai atskleide, kad bendruoju atveju didžiausią poveiki, priimant AT paskirties keitimo sprendimus, turi investicijas ì seniūnijos infrastruktūrą $E_{1}$ $\left(\omega_{\text {avg.E,1 }}=0,079\right)$, žaliujų plotų kiekị $N_{3}\left(\omega_{\text {avg.N,3}}=0,073\right)$, seniūnijoje dominuojančią statybos kainą $E_{2}\left(\omega_{\text {avg.E, }}=0,067\right)$, nenaudojamus žemès plotus $U_{1}\left(\omega_{\text {avg.U,1 }}=0,065\right)$ ir kietujų dalelių koncentraciją ore $N_{2}\left(\omega_{\text {avg.N,2 }}=0,064\right)$ nusakantys rodikliai. Apibendrintas rodiklių reikšmingumo $\omega$ ir standartinès deviacijos $s_{i}$ pagal rangą reikšmių sąrašas pateiktas 3.8 paveiksle.

Skaičiavimai parodè, kad, priklausomai nuo paskirties keitimo $T_{i}$, labiausiai kinta švietimo ir ikimokyklinio ugdymo skaičių $S_{5}\left(s_{S, 5}=0,026\right)$, transporto tarša $N_{4}\left(s_{N, 4}=0,022\right)$ ir darbo vietų skaičių $E_{4}\left(s_{E 4}=0,021\right)$ seniūnijoje nusakančių rodiklių svorio $\omega_{i}$ reikšmè. Mažiausiai kinta patvirtintų ES programų skaičių $E_{3}$, kietujų dalelių koncentraciją $N_{2}\left(\mathrm{~s}_{N, 2}=0,008\right)$ ir pastatų amžių $U_{3}\left(\mathrm{~s}_{U, 3}=0,008\right)$ išreiškiančių rodiklių $\omega_{i}$ reikšmè.

Aukštą $\omega$ reikšmę igijusius rodiklius reikia vertinti priklausomai nuo kiekvieno paskirties keitimo scenarijaus $T_{i}$. Pavyzdžiui, švietimo sistemą reprezentuojančio rodiklio $S_{5}$ reikšmės kinta nuo $0,026\left(T_{2}\right)$ iki $0,091\left(T_{5}\right)$. Taigi švietimo ir ugdymo 
ịstaigu prieinamumas kartu su visa socialine aplinka yra nevienareikšmiškai vertinamas rodiklis. Aplinkos planavimas, užtikrinant socialinès aplinkos kokybę, yra lemiamas veiksnys keičiant AT paskirtị ị sporto aikštynus $\left(T_{3}, \omega_{S, 5 \mid T 3}=0,079\right)$ ir i gyvenamają aplinką $\left(T_{5}, \omega_{55 \mid T 5}=0,091\right)$, o patvirtintų ES programų skaičių seniūnijoje išreiškiančio rodiklio $E_{3}$ savojo svorio $\omega_{i}$ reikšmė kinta mažiausiai - nuo $0,038\left(T_{1}\right)$ iki $0,056\left(T_{2}\right)$.

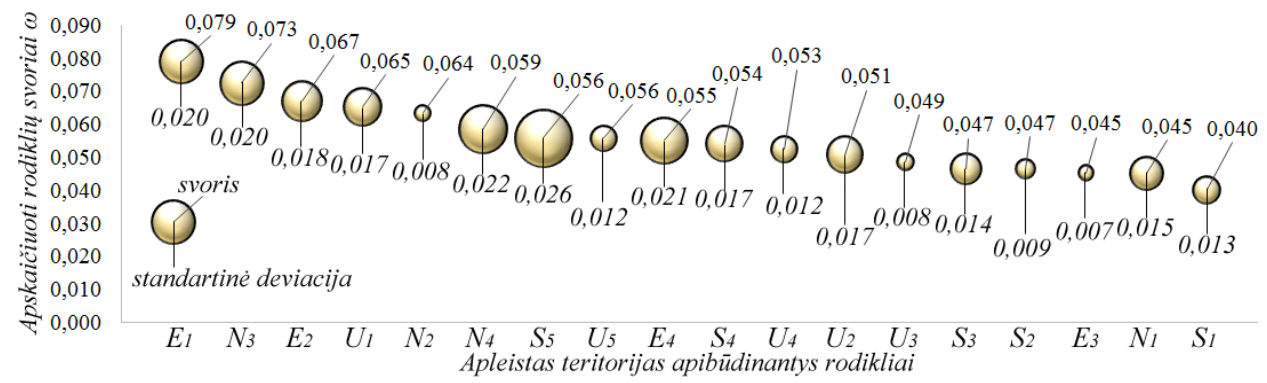

3.8 pav. Apskaičiuotos vidutinès rodiklių svorių $\omega$ ir standartinių deviacijų $s$ reikšmès ivvertinant visus nagrinejjamus apleistų teritorijų paskirties keitimo scenarijus $T_{1-6}$ (sudaryta autoriaus)

Fig. 3.8. The calculated average values $\left(\omega_{C, s}\right)$ of criterion weights and their standard deviations $s$ for each purpose changing the scenario for brownfields (created by author)

Ivertinus šių rodiklių reikšmių svyravimus, galima teigti, kad rodiklių $C_{i}$ jautrumas, priimant paskirties keitimo sprendimus $T_{i}$, yra nevienodas. Jautresni rodikliai, turintys didesnę standartinès deviacijos $s$ reikšmę dèl sunkiai prognozuojamų ir kintančių svorio reikšmių, atliekant strateginị miesto teritorijų planavimą, turi būti laikomi prioritetiniais.

\subsection{Tinkamų miesto dalių atranka, siekiant igyvendinti apleistų teritorijų paskirties keitimo scenarijus}

Sudaryta rodiklių sistema $C$ gali būti taikoma siekiant ne tik nustatyti svarbiausius jų derinius ir svorius priimant konkretų AT paskirties keitimo scenarijų $T_{i}$. Vienas iš svarbiausių TP uždavinių - įvertinti skirtingas miestų teritorijas, esant konkrečiam jų funkciniam naudojimui. Nepaisant to, kad iki šiol AT vertinimo rodikliai buvo vertinti pagal konkretaus AT paskirties keitimo scenarijaus $T_{i}$ igyvendinimo atveji, lieka neatsakyta, kurios miesto zonos arba atskiri teritoriniai vienetai yra tinkamiausi siekiant ịgyvendinti konkrečius AT paskirties keitimo scenarijus $T_{i}$ ? Atsakyti ị tokio pobūdžio klausimus mokslinèje literatūroje plačiai taikomi DSPM. Lietuviškoje 
mokslinejje literatūroje artimiausią tyrimo tematikai (apleistiems pastatams ranguoti) darbą parengè Antuchevičienè et al. $(2011,2012)$.

Ankstesniuose tyrimuose (Bielinskas et al. 2015), taikant ekspertinị vertinimą ir COPRAS DSPM metodą (3.4.3 poskyris), atliktas vertinimas siekiant nustatyti, kokiose Vilniaus miesto seniūnijoje $D_{i}$ pagal esamas faktines rodiklių $C_{E, S, U, N}$ reikšmes yra didžiausia tikimybè atsirasti naujoms AT. Skaičiavimai parodè, kad labiausiai tikètina, jog AT turi sąlygas susidaryti Panerių $\left(D_{8}, Q_{j}=0,084\right)$, Verkių $\left(D_{13}, Q_{j}=0,06\right)$ ir Vilkpèdès $\left(D_{11}, Q_{j}=0,055\right)$ seniūnijose. Mažiausia tikimybè susidaryti AT nustatyta Senamiesčio $\left(D_{20}, Q_{j}=0,036\right)$ ir Naujininkų $\left(D_{3}, Q_{j}=0,037\right)$ seniūnijose (3.9 pav.).

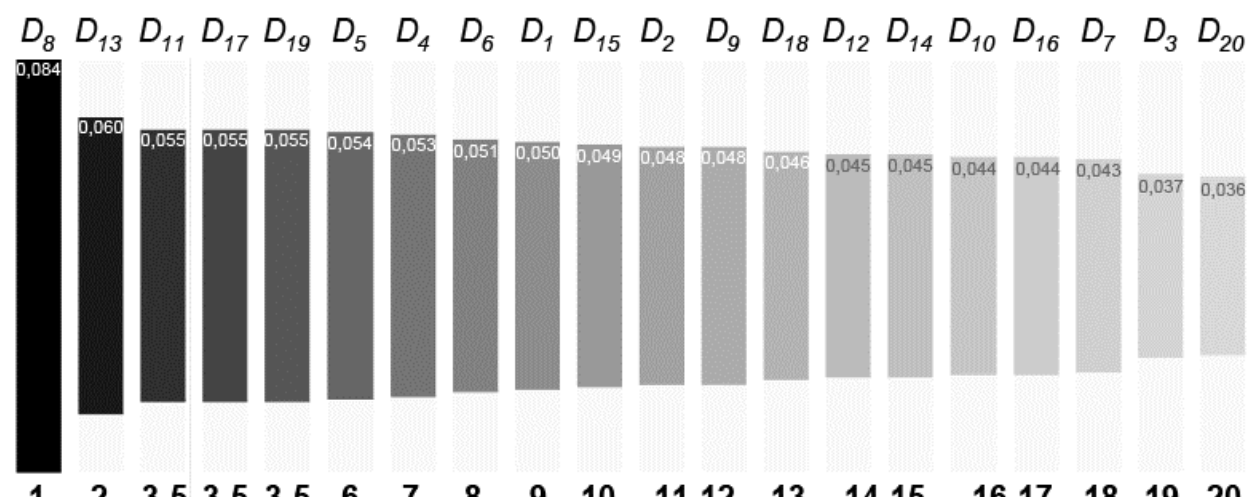

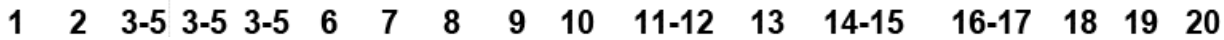

3.9 pav. Santykinių reikšmingumų $Q_{j}$ reikšmès, nusakančios tikimybę didèti apleistų teritorijų skaičiui seniūnijose $D_{i}$ (sudaryta autoriaus)

Fig. 3.9. The values of relative significance $Q_{j}$ defining a probability of an increase in the number of brownfields in neighbourhoods $D_{i}$ (created by author)

Pažymètina tai, kad pastarosioms seniūnijoms būdingas aukštesnis daugiafunkciškumo lygis (2.9 pav.) nei kitoms. Todèl, norint imtis prevencijos priemonių prieš naujų AT atsiradimą, būtina išnagrinèti tinkamiausius AT paskirties keitimo scenarijus konkrečiose miesto zonose, žinant ir ịvertinant naujos AT greičiau susiformuoja esamų AT prieigos zonose. Jeigu vienoje miesto vietoje tinkamiausias AT paskirties keitimo scenarijus yra komercinès zonos plètra, kitoje gali būti priešingai - teritorijos patrauklumą stiprins joje ir aplink ją esančių AT paskirties keitimas ị mišrios paskirties zonas. Tokiu būdu nebus sudaromos tinkamos sąlygos susidaryti naujoms AT, o miesto dalis taptų kompaktiškesné ir patogesné kasdieniams teritorinès bendruomenès poreikiams tenkinti. Tokị funkcinio paskirstymo poreiki skirtingose miesto vietose lemia AT ir jų prieigu daugiafunkciškumas (Bolund, Hunhammar 1999). 
Šiame tyrime nagrinètas atvejis, kai reikia parinkti tinkamiausias miesto seniūnijas ir jose esančiu AT paskirtị pakeisti ị komercinę $\left(T_{2}\right)$, pramoninę $\left(T_{4}\right)$ ir gyvenamają $\left(T_{5}\right)$ paskirtị arba ị daugiafunkcę, ir šioms teritorijoms būtų vienodai būdingos funkcinès šių scenarijų savybès.

\subsubsection{Daugiarodiklių sprendimų prièmimo metodų taikymas apleistų teritorijų žemès paskirties scenarijams miesto seniūnijose vertinti}

Pagrindinė DSPM metodų idejja šiame tyrime - sukurti kaupiamajị rodiklį kiekvienai alternatyvai $D_{i}$, nagrinejjant skirtingas TP ir statybos užduotis (paskirties keitimo scenarijui $\left.T_{i}\right)$. Šis rodiklis atspindi alternatyvos patrauklumą kiekybiniais matais, išreikštais vienetine reikšme kiekvienai alternatyvai (Ginevicius et al. 2012; Jakimavicius et al. 2016; Palevicius et al. 2016). Tai reiškia, kad apskaičiuotas dydis nusako Vilniaus miesto seniūnijos $D_{i}$ patrauklumą skirtingiems jose esančių AT paskirties keitimo scenarijams $T_{i}$ (Bielinskas et al. 2018).

Tyrime taikomi ịvairūs DSPM metodai: paprasčiausias SAW (paprastasis svėrimas sumuojant, angl. Simple Additive Weighting), kuris dèl esminiu DSPM savybių yra dažniausiai pasitaikantis moksliniuose tyrimuose; Lietuvos mokslininkų sukurtas populiarus COPRAS (angl. Complex Proportional Assessment); TOPSIS (angl. Technique for Order Preference by Similarity to an Ideal Solution), taikomas šiuolaikiniuose tyrimuose; naujai pasiūlytas EDAS (angl. Evaluation Based on Distance from Average Solution).

DSPM parinkimas priklauso nuo tikslo, pradinių duomenų ir konteksto (Ginevicius et al. 2012). Kadangi nèra pripažinto nè vieno paties geriausio DSPM metodo, pačiai užduočiai spręsti turi būti taikomi skirtingi DSPM metodai vienu metu. Tai užtikrina užduoties vertinimo tikslumą ir objektyvumą. Kiekvienas DSPM metodas savitas savo savybėmis ir logika, todèl nesutapimai tarp skirtingų metodų rezultatų gali būti sumažinti taikant šiuos metodus vienu metu.

Vertinant tyrimo alternatyvas visiems taikomiems DSPM, naudojama ta pati alternatyvos sprendimų priemimo matrica (toliau-SPM). Jeigu turime tris alternatyvas (AT paskirties keitimo scenarijus $T_{i}$ ), tuomet nagrinejjamos trys SPM visiems DSPM. SPM sudaro statistinių duomenų rinkinys $R=\left\|r_{i j}\right\|$, kuris skaitiškai apibrěžia tyrimo objektą, ir jis turi būti ịvertintas. Rodiklių svoriai išreiškiami taikant $\omega_{i}\left(\sum_{i=1}^{n} \omega_{i}=1\right), i=1,2, \ldots, m ; j=1,2, \ldots, n$ išraišką, čia $m$-rodiklių skaičius, $n$ - nagrinejjamų alternatyvų skaičius. Šiuo atveju rodiklių $C_{i}$ svoriai bus skirtingi kiekvienu iš trijų nagrinejjamų AT paskirties keitimo scenarijų $T_{2,4,5}$ atveju. Visų 
galimų $T_{1-6}$ AT paskirties keitimo scenarijų skirtingose miesto seniūnijose $D_{i}$ vertinimas pateiktas 3.11 paveiksle ir $\mathrm{D}$ priede.

Taikant COPRAS metodą, rodikliai $C$, prieš atliekant skaičiavimus, turi būti apibrěžti kaip maksimizuojamieji arba minimizuojamieji. Didesnė maksimizuojamojo rodiklio reikšmė reiškia didesnį tinkamumą nagrinèjamai alternatyvai. Ir atvirkščiai, mažesnè minimizuojamojo rodiklio reikšmė reiškia didesnị tinkamumą alternatyvai.

Siekiant išsiaiškinti patraukliausias vietas sprendžiant TP uždavinį, šiame tyrime ịvertinti kiekvienos Vilniaus miesto seniūnijos $D_{i}$ AT vertinimo rodikliai $C_{E, S, U, N}$. Atliktas kriteriju vertinimas, vienu metu taikant COPRAS, TOPSIS, SAW ir EDAS (3.5.1 poskyris) DSPM.

Pradžioje taikomas SAW metodas. DSPM taikymo praktika rodo, kad objektų rangavimas, remiantis skirtingais metodais, dažnai sutampa arba mažai skiriasi. SAW metodas labai plačiai taikomas moksliniuose straipsniuose ir yra sukurtas prieš daugelị kitų šiandien praktikoje taikomų DSPM (Saaty 1967, 1980)

Metodo pavadinimas (paprastasis pridedamasis svėrimas, angl. Simple Additive Weighing) atspindi taikymo paprastumą. Šio metodo kriterijus $S_{j}$ yra pasvertųjų rodiklių reikšmių suma (3.20):

$$
S_{j}=\sum_{i=1}^{m} \omega_{i} \times \tilde{r}_{i j},
$$

čia $\omega_{i}-i$-tojo rodiklio svoris; $\tilde{r}_{i j}-j$-ojo objekto $i$-tojo rodiklio normalizuotoji reikšmè. Geriausia rodiklio $S_{j}$ reikšmè yra didžiausia.

Šis metodas veikia tik su maksimizuojamaisiais rodikliais. Visi minimizuojamieji rodikliai keičiami ị maksimizuojamuosius ir apskaičiuojamos jų atvirkštines reikšmes (MacCrimmon 1968; Podviezko, Podvezko 2014).

Normalizuotos maksimizuojamųjų ir minimizuojamujų rodiklių reikšmès apskaičiuojamos pagal (3.21) formulę.

$$
\tilde{r}_{i j}=\left\{\begin{array}{c|l}
\frac{r_{i j}-\min _{j} \times r_{i j}}{\max _{j} \times r_{i j}-\min _{j} \times r_{i j}} \\
\frac{\max _{j} \times r_{i j}-r_{y}}{\max _{j} \times r_{i j}-\min _{j} \times r_{i j}}
\end{array}\right\} \begin{aligned}
& , \text { jeigu } i \text { yra minimizuo- } \\
& \text { jamasis rodiklis; } \\
& \begin{array}{l}
, \text { jeigu } i \text { yra maksimizuo- } \\
\text { jamasis rodiklis. }
\end{array}
\end{aligned}
$$

Kai rodiklių reikšmès skiriasi nedaug tarp alternatyvų (seniūnijų $D_{i}$ ), tokia normalizacija pervertina rodiklio itaką. Dèl to atliktas rodiklių verčių skirtumo testas. Atliekus skaičiavimus, išryškejjo du atvejai ir tarp nagrinejjamų alternatyvų 
nustatyti nedideli rodiklių normalizuotųų reikšmių skirtumai. Kriterijaus $E_{1}$ (skirtos investicijos ị aplinką seniūnijoje $D_{i}$ ) reikšmès tarp alternatyvų $D_{i}$ kinta daugiausia apie $31 \%$, o rodiklis $S_{3}$ (vidutinès namų ūkio pajamos seniūnijose $D_{i}$ ) kinta dar mažiau. Šiems dviem rodikliams normalizuoti taikytas klasikinès normalizacijos būdas: rodiklių reikšmės padalytos iš jų reikšmių sumos visoms alternatyvoms $D_{i}$. Normalizuotos rodiklių reikšmès naudotos taikant COPRAS metodą).

Taikant ši metodą, atkreipiamas dėmesys, kad rezultatai priklauso nuo rodiklių normalizacijos krypties, kuri gali skirtis priklausomai nuo parinkto AT paskirties keitimo scenarijaus $\left(T_{i}\right)$. Vertinant rodiklius, AT paskirties keitimo scenarijų $T_{2}, T_{4}$ ir $T_{5}$ atvejais jų normalizacijos kryptys pateiktos D priedo D.1 lentelëje.

COPRAS metodą sukūrè 1996 m. Vilniaus Gedimino technikos universiteto mokslininkai Zavadskas ir Kaklauskas (Zavadskas, Kaklauskas 1996). Šio metodo esmè - visų rodiklių $R_{i}$ reikšmes $r_{i j}$ galima susieti ị vieną kokybinị vertinimą metodo rodiklio reikšmę. Skaičiuojant COPRAS metodu, taikomas klasikinis normalizavimo būdas pagal (3.22) formulę.

$$
\widehat{r}_{i j}=\frac{r_{i j}}{\sum_{j=1}^{n} r_{i j}}
$$

Taikant ši metodą, nagrinëjamų variantų prioritetiškumas ir jų svarbumo laipsnis tiesiogiai priklauso nuo alternatyvas apibūdinančių rodiklių sistemos, ir reikšmingumo dydžių. Skaičiuojama pagal penkių žingsnių sistemą pagal (3.23)-(3.26) formules.

1-asis žingsnis:

$$
d_{i j}=\frac{r_{i j} \times \omega}{\sum_{j=1}^{n} r_{i j}}, i=\overline{1, m} ; j=\overline{1, n}
$$

čia $r_{i j}-i$-tojo rodiklio $j$-ojo sprendimo alternatyvos variantas; $m$-rodiklių skaičius; $n$ - lyginamujų variantų skaičius; $\omega_{i}-i$-tojo rodiklio $k$-tojo eksperto suskaičiuoti svoriai.

2-asis žingsnis. Apskaičiuojamos $j$ variantą apibūdinančių minimizuojamųjų $S_{-j}$ ir maksimizuojamųų $S_{+1}$ ịvertintų normalizuotų rodiklių sumos. Jos apskaičiuojamos pagal (3.24) formulę.

$$
S_{ \pm j}=\sum_{i=1}^{m} d_{ \pm i j} .
$$

3-iasis žingsnis. Lyginamas variantų santykinis reikšmingumas. Šis dydis nustatomas remiantis juos apibūdinančiomis teigiamomis $S_{+j}$ ir neigiamomis $S_{-j}$ 
savybėmis. Kiekvieno varianto $\alpha_{j}$ santykinis reikšmingumas $Q_{j}$ nustatomas pagal (3.25) formulę.

$$
Q_{j}=S_{+j}+\frac{S_{-\min } \times \sum_{j=1}^{n} S_{-j}}{S_{-j} \times \sum_{j=1}^{n} \frac{S_{-\min }}{S_{-j}}}, j=\overline{1, n} .
$$

4-asis žingsnis. Nustatoma variantų prioritetų eilès tvarka. Kuo didesnis $Q_{j}$, tuo varianto efektyvumas yra didesnis.

5-asis žingsnis. Pagal (3.26) formulę apskaičiuojamas varianto naudingumo laipsnis.

$$
N_{j}=\frac{Q_{j}}{Q_{\max }} \times 100 \%,
$$

čia $N_{j}$ - naudingumo laipsnis, $\%$.

COPRAS metodo skaičiavimų rezultatai pateikti D priedo D2-D13 lentelèse. alternatyvūs skaičaivimai atliekami taikant TOPSIS metodą. Tai sprendimo prièmimo metodas, pagal kuri nustatomas artumas iki idealiojo taško, sukurtas $1981 \mathrm{~m}$. Remiantis šiuo metodu, pasirinkta geriausia alternatyva, kuri turi mažiausią atstumą iki geriausio sprendimo ir didžiausią atstumą iki blogiausio sprendimo (Hwang, Yoon 1981). Šis metodas pasižymi universaliu matematiniu algoritmu, todèl labai plačiai taikomas inžinerinių mokslų darbuose (Aloini 2018; Parfenova et al. 2016; Palevicius et al. 2017; Jakimavicius et al. 2016).

Pirmojo etapo skaičiavimai atliekami pagal (3.27) formulę:

$$
\tilde{r}_{i j}=\frac{r_{i j}}{\sqrt{\sum_{j=1}^{n} r_{i j}^{2}}},
$$

čia $\tilde{r}_{i j}^{2}-i$-tojo rodiklio $j$-ojo objekto normalizuotoji reikšmè.

Geriausias sprendinys (variantas) $V^{*}$ ir blogiausias $-V^{-}$skaičiuojami pagal (3.28) ir (3.29) formules:

$$
V^{*}=\left\{V_{1}^{*}, V_{2}^{*}, \ldots, V_{m}^{*}\right\}=\left\{\left(\frac{\max _{j} \omega_{i} \times \tilde{r}_{i j}}{i \in I_{1}}, \frac{\min _{j} \omega_{i} \times \tilde{r}}{i \in I_{2}}\right)\right\} ;
$$




$$
V^{-}=\left\{V_{1}^{-}, V_{2}^{-}, \ldots, V_{m}^{-}\right\}=\left\{\left(\frac{\max _{j} \omega_{i} \times \tilde{r}_{i j}}{i \in I_{1}}, \frac{\min _{j} \omega_{i} \times \tilde{r}}{i \in I_{2}}\right)\right\}
$$

Skaičiuojamas kiekvieno lyginamojo varianto bendrasis atstumas $D_{j}^{*}$ iki geriausių sprendinių ir $D_{j}^{-}-$iki blogiausių spre ndinių pagal (3.30) ir (3.31) formules:

$$
\begin{aligned}
& D_{j}^{*}=\sqrt{\sum_{i=1}^{m}\left(\omega_{i} \times \tilde{r}_{i j}-V_{i}^{*}\right)^{2}} ; \\
& D_{j}^{*}=\sqrt{\sum_{i=1}^{m}\left(\omega_{i} \times \tilde{r}_{i j}-V_{i}^{*}\right)^{2}} .
\end{aligned}
$$

Toliau TOPSIS metodu skaičiuojamasis rodiklis $C_{j}^{*}$, kuris nustatomas pagal (3.32) formulę.

$$
C_{j}^{*}=\frac{D_{1}^{-}}{D_{j}^{*}+D_{j}^{-}}(j=1,2, \ldots, n),\left(0 \leq C_{j}^{*} \leq 1\right) .
$$

Atliktų TOPSIS metodo skaičiavimų rezultatai pateikti D priedo D.2 ir D.13 lentelèse.

Toliau rodiklių svorių nustatytas atliktas taikant EDAS metodą. EDAS metodu atliekamas vertinimas remiasi atstumu nuo vidutinio sprendimo ir yra panašus $\mathfrak{i}$ TOPSIS metodą. Pagal EDAS metodą geriausia alternatyva yra susijusi su atstumu nuo vidutinio sprendimo (Keshavarz Ghorabaee et al. 2015). Pagal ši metodą geriausia alternatyva vertinama dviem būdais. Pirmasis būdas, kai skaičiuojamas „teigiamas“ atstumas (angl. positive distance (PD) nuo vidutinio sprendimo. Antruoju atveju skaičiuojamas ,neigiamas“ atstumas (angl. negative distance (ND) nuo vidutinio sprendimo. Alternatyvos $D_{i}$ vertinamos pagal didžiausią PD ir mažiausią ND reikšmę. EDAS metodo skaičiavimas, kaip ir taikant kitus DSPM, pradedamas nuo sprendimo matricos sudarymo $R$. Toliau atliekami (3.33) ir (3.40) formulèse nurodyti veiksmai.

1-asis žingsnis. Apskaičiuojamas visų rodiklių vidurkis:

$$
A V_{i}=\frac{\sum_{j=1}^{m}}{m} \text {. }
$$


2-asis žingsnis. Atskirai maksimizuojamiems rodikliams šiame etape apskaičiuojami kiekvienos alternatyvos $D_{i}$ teigiami (PD) ir neigiami (ND) atstumai nuo vidurkio:

$$
\begin{aligned}
& P D A_{i j}=\frac{\max \left(0,\left(r_{i j}-A V_{i}\right)\right)}{A V_{i}} ; \\
& N D A_{i j}=\frac{\max \left(0,\left(A V_{i}-r_{i j}\right)\right)}{A V_{i}} ; \\
& P D A_{i j}=\frac{\max \left(0,\left(A V_{i}-r_{i j}\right)\right)}{A V_{i}} ; \\
& N D A_{i j}=\frac{\max \left(0,\left(r_{i j}-A V_{i}\right)\right)}{A V_{i}},
\end{aligned}
$$

čia $j$-asis rodiklis yra maksimizuojamasis.

3-iasis žingsnis. Šiame žingsnyje atliekamas visų alternatyvų SP ir SN reikšmių normalizavimas apskaičiuojant $N S P_{j}$ and $N S N_{j}$ reikšmes:

$$
\begin{gathered}
N S P_{j}=\frac{\sum_{i=1}^{n} \omega_{i} \times P D A_{i j}}{\max _{j} \sum_{i=1}^{n} \omega_{i} \cdot P D A_{i j}} . \\
N S P_{j}=1-\frac{\sum_{i=1}^{n} \omega_{i} \times P D A_{i j}}{\max _{j} \sum_{i=1}^{n} \omega_{i} \times N D A_{i j}} .
\end{gathered}
$$

4-asis žingsnis. Visų alternatyvų $D_{i}$ vertinimo balo (angl. appraisal score (AS)) skaičiavimas pagal (3.37) formulę.

$$
A S_{j}=\frac{1}{2} \times\left(N S P_{j}+N S N_{j}\right),
$$

čia $0 \leq A S_{i} \leq 1$.

Skaičiavimų rezultatai pateikti ir įvertinti 3.4 .6 ir 3.47 poskyriuose. 


\subsubsection{Tinkamų seniūnijụ parinkimo apleistụ teritorijų žemės paskirties scenarijams igyvendinti rezultatai}

Nèra pripažinto patikimiausio DSPM ir, siekiant sumažinti neatitikimų tikimybę, kiekvienas šių metodų paprastai lemia skirtingus rezultatus. Galutinis rezultatas derinamas atsižvelgiant ị DSPM rezultatus, atskirai atsižvelgiant i jų variacijos koeficientą ir laikantis prielaidos, kad tai atspindi jų reikšmingumą bendrajam vertinimui. Metodas, turintis didesnį variacijos koeficientą, laikomas patikimesniu alternatyvoms $D_{i}$ ịvertinti ir daro ịtaką alternatyvos rango $R n$ nustatymui. Skaičiavimų rezultatų ir nustatytų alternatyvų $D_{i}$ rangų kiekvieno DSPM atveju fragmentas pateiktas analizuojant AT paskirties keitimą ị komercinès paskirties teritorijas $\left(T_{2}\right)$. Rezultatai pateikti 3.8 ir 3.9 lentelèse ir D priede.

3.8 lentelè. Daugiarodiklių sprendimo prièmimo metodų vertinimo rezultatai scenarijui $T_{2}$

Table 3.8. The results of evaluating multiple-attribute decision-making methods for the task $T_{2}$

\begin{tabular}{|l|l|c|c|c|c|c|c|c|c|c|c|}
\hline DSPM & Dyd- & \multicolumn{10}{|c|}{ Seniūnijos } \\
\cline { 2 - 13 } Metodai: & žiai & $D_{1}$ & $D_{2}$ & $D_{3}$ & $D_{4}$ & $D_{5}$ & $D_{6}$ & $D_{7}$ & $D_{8}$ & $D_{9}$ & $D_{10}$ \\
\hline \multirow{2}{*}{ SAW } & $S_{j}$ & 0,472 & 0,336 & 0,424 & 0,425 & 0,373 & 0,429 & 0,342 & 0,505 & 0,337 & 0,317 \\
\cline { 2 - 13 } & $R n$. & 2 & 18 & 7 & 6 & 12 & 4 & 16 & 1 & 17 & 20 \\
\hline \multirow{2}{*}{ TOPSIS } & $C_{j}^{*}$ & 0,382 & 0,289 & 0,393 & 0,365 & 0,317 & 0,384 & 0,265 & 0,597 & 0,291 & 0,277 \\
\cline { 2 - 13 } & $R n$. & 7 & 15 & 3 & 9 & 12 & 5 & 20 & 1 & 14 & 19 \\
\hline \multirow{2}{*}{ COPRAS } & $Z_{j}$ & 0,052 & 0,044 & 0.044 & 0.047 & 0.049 & 0.058 & 0.042 & 0.070 & 0.043 & 0,050 \\
\cline { 2 - 12 } & $R n$. & 7 & 15 & 17 & 13 & 11 & 3 & 20 & 1 & 18 & 10 \\
\hline \multirow{2}{*}{ EDAS } & $A S_{j}$ & 1,060 & 0,696 & 1,043 & 0,986 & 0,787 & 0,886 & 0,653 & 1,137 & 0,564 & 0,599 \\
\cline { 2 - 12 } & $R n$. & 2 & 14 & 3 & 5 & 12 & 8 & 16 & 1 & 20 & 19 \\
\hline \multirow{2}{*}{$n$} & & 2 & 14 & 3 & 6 & 12 & 7 & 18 & 1 & 19 & 20 \\
\hline
\end{tabular}

3.9 lentelè. Daugiarodiklių sprendimo prièmimo metodų vertinimo rezultatai scenarijui $T_{2}$

Table 3.9. The results of evaluating multiple-attribute decision-making methods for the task $T_{2}$

\begin{tabular}{|l|c|c|c|c|c|c|c|c|c|c|c|}
\hline DSPM & Dyd- & \multicolumn{10}{|c|}{ Seniūnijos } \\
\cline { 3 - 13 } Metodai & žiai & $D_{11}$ & $D_{12}$ & $D_{13}$ & $D_{14}$ & $D_{15}$ & $D_{16}$ & $D_{17}$ & $D_{18}$ & $D_{19}$ & $D_{20}$ \\
\hline 1 & 2 & 3 & 4 & 5 & 6 & 7 & 8 & 9 & 10 & 11 & 12 \\
\hline SAW & $S_{j}$ & 0,389 & 0,381 & 0,446 & 0,343 & 0,346 & 0,334 & 0,426 & 0,349 & 0,405 & 0,403 \\
\hline & $R n$. & 10 & 11 & 3 & 15 & 14 & 19 & 5 & 13 & 8 & 9 \\
\hline \multirow{2}{*}{ TOPSIS } & $C_{j}^{*}$ & 0,347 & 0,439 & 0,383 & 0,283 & 0,304 & 0,279 & 0,372 & 0,289 & 0,360 & 0,393 \\
\cline { 2 - 13 } & $R n$. & 11 & 2 & 6 & 17 & 13 & 18 & 8 & 16 & 10 & 4 \\
\hline \multirow{2}{*}{ COPRAS } & $Z_{j}$ & 0,043 & 0,053 & 0,050 & 0,044 & 0,050 & 0,047 & 0,058 & 0,044 & 0,055 & 0,055 \\
\cline { 2 - 13 } & $R n$ & 19 & 6 & 9 & 16 & 8 & 12 & 2 & 14 & 4 & 5 \\
\hline
\end{tabular}


3.9 lenteles pabaiga

\begin{tabular}{|l|c|c|c|c|c|c|c|c|c|c|c|}
\hline \multirow{2}{*}{ EDAS } & $A S_{j}$ & 0,898 & 0,858 & 1,001 & 0,608 & 0,773 & 0,660 & 0,914 & 0,604 & 0,849 & 0,849 \\
\cline { 2 - 13 } & $R n$ & 7 & 9 & 4 & 17 & 13 & 15 & 6 & 18 & 10 & 11 \\
\hline$\widetilde{R} n$ & & 9 & 8 & 4 & 17 & 13 & 15 & 5 & 16 & 11 & 10 \\
\hline
\end{tabular}

3.8 ir 3.9 lentelèse pateikti atliktų skaičiavimų rezultatai rodo, kad Panerių $\left(D_{8}, \quad \widetilde{R} n=1\right)$, Rasų $\left(D_{1}, \quad \widetilde{R} n=2\right)$, Naujininkų $\left(D_{3}, \quad \widetilde{R} n=3\right)$ seniūnijas skaičiavimo modelis parenka kaip optimalias miesto dalis AT paskirčiai keisti i komercinès paskirties teritorijas $\left(T_{2}\right)$.

Koreliacijos koeficientai tarp skirtingų DSPM porų apskaičiuotų svorių reikšmių, atsižvelgiant ị kiekvieną nagrinejamą AT paskirties keitimo scenarijų $T_{2,4,5}$, i vertinimą įtraukiant nedideles išimtis ir taikant COPRAS metodą, pateikti 3.10 lentelëje. Tyrimo metu pastebèta, kad tokių neatitikimų atsiranda dèl skirtingos rodiklio minimizavimo įtakos rezultatui (Podvezko 2011). Nepaisant to, COPRAS metodas nebuvo pašalintas iš tyrimo dèl jo populiarumo bei plataus taikymo masto.

3.10 lentelè. Koreliacijos koeficientų tarp skirtingų daugiarodiklių sprendimo priëmimo metodų ịvertinimo porų reikšmès

Table 3.10. The values of the correlation coefficients between the pairs of the sets of values of cumulative criteria for multiple-attribute decision-making methods

\begin{tabular}{|l|c|c|c|c|c|c|}
\hline \multirow{3}{*}{ Scenarijai } & \multicolumn{6}{|c|}{ Daugiarodikliu metodu poru santykis } \\
\cline { 2 - 7 } & $\begin{array}{c}\text { SAW/ } \\
\text { TOPSIS }\end{array}$ & $\begin{array}{c}\text { SAW/ } \\
\text { COPRAS }\end{array}$ & $\begin{array}{c}\text { TOPSIS/ } \\
\text { COPRAS }\end{array}$ & $\begin{array}{c}\text { SAW/ } \\
\text { EDAS }\end{array}$ & $\begin{array}{c}\text { COPRAS/ } \\
\text { EDAS }\end{array}$ & $\begin{array}{c}\text { TOPSIS/ } \\
\text { EDAS }\end{array}$ \\
\hline$T_{2}$ & 0,854 & 0,667 & 0,794 & 0,941 & 0,56 & 0,822 \\
\hline$T_{4}$ & 0,908 & 0,873 & 0,862 & 0,964 & 0,871 & 0,962 \\
\hline$T_{5}$ & 0,961 & 0,711 & 0,714 & 0,861 & 0,910 & 0,901 \\
\hline
\end{tabular}

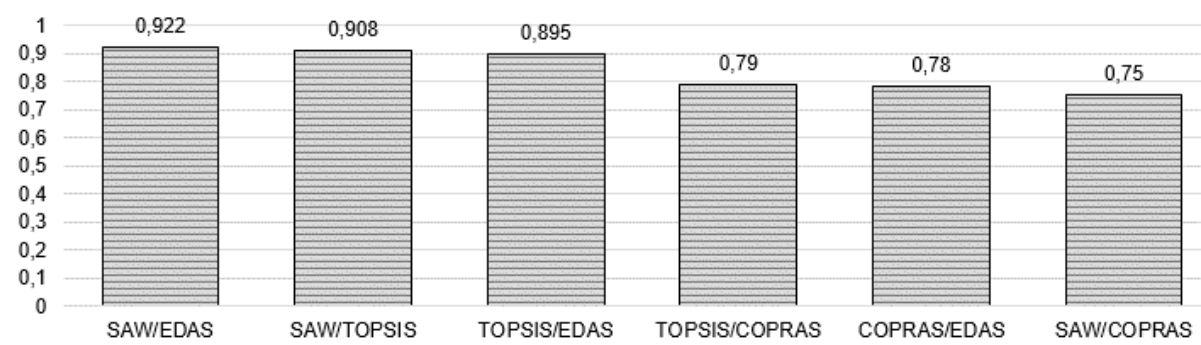

3.10 pav. Koreliacijos koeficientų tarp skirtingų daugiarodiklių sprendimo prièmimo metodu ịvertinimo vidutinès reikšmès (sudaryta autoriaus)

Fig. 3.10. The average values of different correlation coefficients for multiple-attribute decision-making methods applied in the study (created by author) 
Detali rezultatų analizè ir kokybinis vertinimas pateiktas 3.4.7 skyrelyje.

\subsubsection{Tinkamų seniūnijų parinkimo konkrečiam apleistos teritorijos paskirties keitimo scenarijui rezultatų kokybinis vertinimas}

Kadangi egzistuoja skirtingos rezultatų variacijos, gautos taikant skirtingus DSPM metodus, alternatyvas $D_{i}$ galima kategorizuoti į dvi ar daugiau reikšminių klasių (pvz., patrauklus, ne toks patrauklus arba netinkamas) (Doumpos, Zopounidis 2002).

Remiantis sukurta metodika ir siekiant nustatyti miesto seniūnijas $D_{i}$, kuriose miesto plètros poreikis yra didžiausias, naudojant AT kaip nepanaudotus miestų išteklius, pasirinkti paskirties keitimo scenarijai $T_{2,4,5}$. Kompleksiškas jų igyvendinimas skirtingose Vilniaus vietose labiausiai atspindi šiandienius miesto prioritetus ir šiuo metu mieste dominuojančias teritorijų funkcijas. Taikant šią idèją, skaičiavimais paremti alternatyvų $D_{i}$ ịvertinimai perskaičiuoti i penkias tinkamiausias miesto plètrai klases (pirmoji - tinkamiausia, 3.11 lentelè).

Skaičiavimai parodè, kad AT paskirties keitimo scenarijui $T_{2}$ igyvendinti labiausiai pritaikytos yra Panerių $\left(D_{8}\right)$, Rasų $\left(D_{1}\right)$, Naujininkų $\left(D_{3}\right)$, Verkių $\left(D_{13}\right)$, Antakalnio $\left(D_{17}\right)$ ir Pilaitès $\left(D_{4}\right)$ seniūnijos. Planuojant miesto plètrą, pirmiausia turi būti panaudojamos šiose seniūnijose esančios AT, atsižvelgiant ị seniūnijų $D_{i}$ prioritetiškumo laipsnị $P r$. Mažesnè $P r$ reikšmè sudaro prielaidą ịgyvendinti šią miesto plètrą seniūnijoje $D_{i}$ anksčiau nei kitose, turinčiose aukštesnę $\operatorname{Pr}$ reikšmę.

AT paskirties keitimo ị pramoninę paskirti $\left(T_{4}\right)$ scenarijaus igyvendinimas labiausiai atitinka Naujamiesčio $\left(D_{12}\right)$, Naujininkų $\left(D_{3}\right)$, Verkių $\left(D_{13}\right)$, Senamiesčio $\left(D_{20}\right)$ ir Rasų $\left(D_{1}\right)$ seniūnijas apibrèžiančius rodiklius. Išlaikant toki patị planavimo principą, skaičiuojant nustatyta, kad AT paskirties keitimas ị gyvenamają paskirtị $\left(T_{5}\right)$ turi būti planuojama Justiniškių $\left(D_{9}\right)$, Viršuliškių $\left(D_{10}\right)$, Šnipiškių $\left(D_{6}\right)$ ir Fabijoniškių $\left(D_{18}\right)$ seniūnijose.

Apytikriai tokio paties dydžio koreliacijos koeficientų reikšmės rodo, kad, atliekant keičiant AT paskirtị visais nagrinejjamais scenarijais $T_{i}$, nagrinėjamos alternatyvos atveju (konkrečioje seniūnijoje) $D_{i}$ gali būti planuojamos mišrios paskirties zonos.

Skirtingai nei AT paskirties keitimas ị vieną konkrečią paskirtị $T_{i}$, mišraus teritorijų funkcionalumo $T_{1,2,3}$ plètra, kai viena AT arba greta esančios AT (priklausančios tai pačiai miesto teritorinès bendruomenès veikimo zonai) keičiamos iš karto, joms suteikiant keletą funkcijų, mažina tos vietovès anonimiškumą ir atlieka kriminogeninès prevencijos vaidmenį (Bielinskas et al. 2014; Chiesura 2004). Tokia plètros kryptis ypač svarbi miestų teritorijoms, kuriose vyrauja aukštas nusikalstamumo lygis, marginalinių bendruomenių koncentracija, žemas ekonominis lygis, o estetinis aplinkos įvaizdis neatitinka vietovès identiteto. 
3.11 lentelè. Apleistų teritorijų galimų paskirties keitimo scenarijų tinkamumas $\bar{\omega}$ pagal seniūnijas $D_{i}$.

Table 3.11. Appropriate possible scenarios $\bar{\omega}$ for changes in the purpose of brownfields according to neighbourhoods $D_{i}$.

\begin{tabular}{|c|c|c|c|c|c|c|}
\hline \multirow{2}{*}{ Rangas } & \multicolumn{6}{|c|}{ Paskirties keitimo scenarijai } \\
\cline { 2 - 7 } & \multicolumn{2}{|c|}{$T_{2}$} & \multicolumn{2}{c|}{$T_{4}$} & \multicolumn{2}{c|}{$T_{5}$} \\
\cline { 2 - 7 } & Seniūnija & $\bar{\omega}$ & Seniūnija & $\bar{\omega}$ & Seniūnija & $\bar{\omega}$ \\
\hline 1 & $D_{8}^{I V}$ & 0,577 & $D_{12}^{I I I}$ & 0,510 & $D_{9}^{I I I}$ & 0,538 \\
\hline 2 & $D_{1}^{I I I}$ & 0,492 & $D_{3}^{I I}$ & 0,436 & $D_{14}^{I I I}$ & 0,513 \\
\hline 3 & $D_{3}^{I I}$ & 0,476 & $D_{13}^{I I}$ & 0,399 & $D_{10}^{I}$ & 0,508 \\
\hline 4 & $D_{13}^{I I}$ & 0,47 & $D_{20}^{I V}$ & 0,395 & $D_{6}^{I}$ & 0,488 \\
\hline 5 & $D_{17}^{I V}$ & 0,443 & $D_{1}^{I I I}$ & 0,382 & $D_{18}^{I V}$ & 0,487 \\
\hline
\end{tabular}

Analizè (3.11 lentelè), parodè, kad mišrios paskirties planavimas, tolygiai įtraukiant komercinès, pramoninès ir gyvenamosios paskirties funkcijas $T_{2,4,5}$ panaudojant esamas AT, labiausiai tinkamas plètoti Rasų $\left(D_{1}\right)$, Naujininkų $\left(D_{3}\right)$ ir Verkių $\left(D_{13}\right)$ seniūnijose. Konkrečios vietovès (Naujininkų seniūnijoje) AT modelis, keičiant komercinę $\left(T_{2}\right)$, pramoninę $\left(T_{4}\right)$ ir gyvenamają $\left(T_{5}\right)$ paskirtị bei priskiriant naujas funkcijas teritorijoje esantiems apleistiems pastatams, pateiktas 3.11 paveiksle.

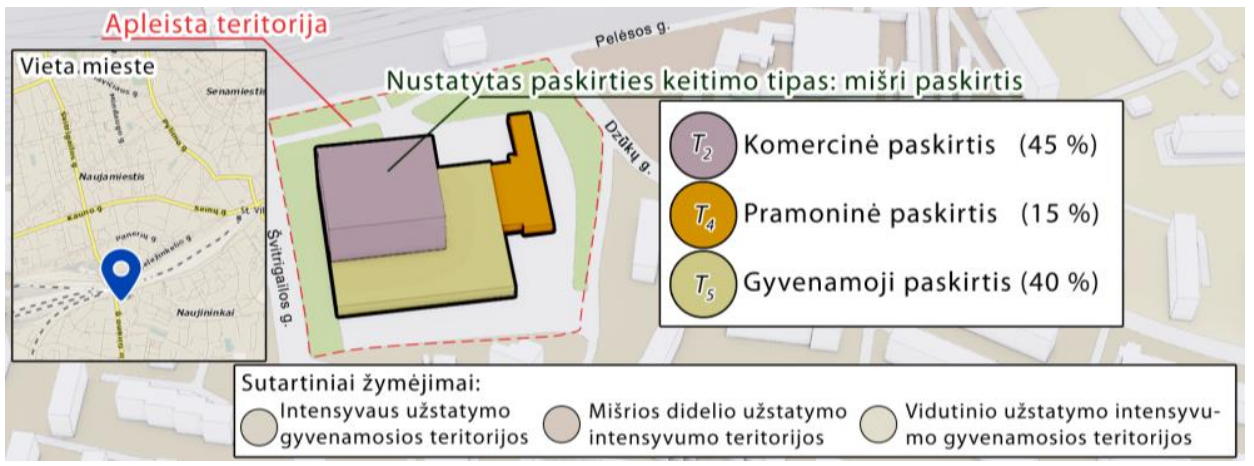

3.11 pav. Apleistų teritorijų žemės paskirties keitimas ị mišraus funkcionalumo paskirtị. Realios vietovès Vilniaus mieste teorinis modelis (sudaryta autoriaus)

Fig. 3.11. The replacement of brownfield land use for mixed functional purposes. The theoretical model for the real site in Vilnius city (created by author) 
Apskaičiavus koreliacijos koeficientus tarp skirtingų DSPM metodų porų, nustatyta, kad SAW, TOPSIS ir EDAS metodai yra tinkamiausi $T_{2,4,5}$ AT paskirties keitimo scenarijams seniūnijose nustatyti (didžiausia koreliacijos koeficiento tarp šių DSPM metodų poros reikšmé kitų metodų porų atžvilgiu).

Atsižvelgiant ì parengtas seniūnijų $D_{i}$ prioritetines grupes, nustatyti AT paskirties keitimo scenarijai $T_{i}$ turi būti ịgyvendinami pagal nustatytą prioritetu eilę, pradedant nuo didžiausio prioritetiškumo laipsnio $\operatorname{Pr}$ seniūnijų. Šiuo atveju pirmieji AT paskirties keitimo procesai turi būti pradedami Naujininkuose $\left(D_{3}\right)$. Šioje seniūnijoje geriausias variantas yra paskirties keitimas plečiant mišraus funkcionalumo komercinès $\left(T_{2}\right)$ ir pramoninès $\left(T_{4}\right)$ paskirties teritorijas. Remiantis atliktais skaičiavimais, AT paskirties keitimas ị gyvenamąsias zonas $\left(T_{5}\right)$ turi būti vykdomas pradedant nuo šiam paskirties keitimo scenarijui apskaičiuotų didžiausio laipsnio $\operatorname{Pr}$ seniūnijų - Rasų $\left(D_{1}\right)$ ir Šnipiškių $\left(D_{6}\right)$.

Remiantis skaičiavimų rezultatais, galima teigti, kad šie metodai gali būti sėkmingai taikomi nustatyti AT paskirties keitimo scenarijams $T_{1-6}$ tinkamiausias miesto zonas (arba kitokio mastelio teritorinius vienetus), pritaikomas Vilniaus ir kitiems panašų dydį, gyventojų skaičių ir gamtines savybes (reljefas, upių tinklas ir kt.) turintiems Centrinès Europos miestams. Praktiniam taikymui privalu AT vertinti ne kaip miesto piktžaizdę ar grèsmę miesto ịvaizdžiui.

\subsubsection{Apleistų teritorijų paskirties keitimo scenarijų igyvendinimo strategija ir reglamentavimas}

Remiantis atliktu tyrimu analizuojama, kuriose Vilniaus miesto seniūnijose $D_{i}$ strateginio planavimo lygmeniu racionaliausia vykdyti teritorijų planavimo plètrą taikant $T_{2,4,5}$ AT paskirties keitimo scenarijus. Tačiau šių scenarijų gali būti daugiau ir kitokių, priklausomai nuo miesto ekonominès, socialinès, urbanistinès ir gamtinès aplinkos savybių. Siekiant suformuoti kompleksinę ir visas miesto posistemes apimančią detalizuotą planavimo strategiją, būtina pirmiau aprašytais vertinimo modeliais apskaičiuoti visu galimų AT paskirties keitimo scenarijų $T_{i}$ tinkamumą. Čia vertiname visų anksčiau apibrèžtų AT paskirties keitimo scenarijų $T_{1-6}$ tinkamumą Vilniaus miesto plètrai nuo 5 iki 10 metų ị ateitį.

I skaičiavimo modeli įtraukus visus nagrinejjamus AT paskirties keitimo scenarijus $T_{1-6}$, gaunama koreliacijos koeficientu matrica, kurios eilučių skaičius atitinka nagrinèjamų AT paskirties keitimo scenarijų skaičių, kai stulpelių skaičius - taikomų DSPM poros, kurioms skaičiuotas koreliacijos koeficientas $R$ (3.12 pav.). Siekiant ịvykdyti darbo tikslą ir numatant kartotinius tyrimus ateityje, sprendiniai gali būti grindžiami supaprastinant skaičiavimą eigą i juos įtraukiant kiekvienam AT paskirties keitimo scenarijui tinkamiausius prognozuoti tinkančius DSPM. Tai yra išimtinis atvejis, kai pasiekiamas istorinių duomenų kiekis, kuomet juos apdorojant reikia pasitelkti optimizacijos metodus 
didžiujų duomenų saugojimo sistemose (pavyzdžiui Google Cloud Platform, Amazon Web Service ir kt.). Gauti rezultatai nurodo, kurie DSPM gali būti taikomi kompleksiškai prognozuojant tinkamiausią naują AT paskirti.

\begin{tabular}{|c|c|c|c|c|c|c|}
\hline & COPRAS / EDAS & SAW / COPRAS & SAW / EDAS & SAW / TOPSIS & SAW / COPRAS & TOPSIS/EDAS \\
\hline$T_{1}$ & 0,59 & 0,91 & 0,61 & 0,72 & 0,51 & 0,85 \\
\hline$T_{2}$ & 0,56 & 0,67 & 0,94 & 0,85 & 0,79 & 0,82 \\
\hline$T_{3}$ & 0,64 & 0,95 & 0,73 & 0,76 & 0,74 & 0,86 \\
\hline$T_{4}$ & 0,87 & 0,87 & 0,96 & 0,91 & 0,86 & 0,96 \\
\hline$T_{5}$ & 0,91 & 0,71 & 0,86 & 0,96 & 0,71 & 0,90 \\
\hline$T_{6}$ & 0,55 & 0,98 & 0,62 & 0,91 & 0,89 & 0,71 \\
\hline & & & & & $\bar{R}=0,80$ & $M d=0,85$ \\
\hline
\end{tabular}

3.12 pav. Koreliacijos koeficientų $R$ tarp skirtingų daugiarodiklių sprendimo prièmimo metodų rezultatų kiekvieno paskirties keitimo scenarijaus atveju $T_{i}$ (sudaryta autoriaus)

Fig. 3.12. Correlation coefficients $R$ between the results of different multiple-attribute decision-making methods taking into account each case of the scenario for changes in land purpose $T_{i}$ (created by author)

Ivertinus visus AT paskirties keitimo scenarijus, akivaizdu, kad tam tikrų DSPM metodų porų rezultatai yra suderinti. Pavyzdžiui, $T_{4}$ scenarijaus atveju koreliacijos koeficientas $R$ net tarp dviejų DSPM porų apskaičiuotas $0,96(\approx 1)$, o $T_{6}$ scenarijaus atveju SAW/COPRAS rezultatų koreliacijos koeficientas yra 0,98 $(\approx 1)$, bendras reikšmių pasiskirstymas pasižymi marginaliomis (angl. outliers) ir pagrindinèmis reikšmių zonomis ir t. t.

Vertinant visus gautus rezultatus matyti, kad koreliacijos koeficientu reikšmès tarp skirtingų DSPM metodų porų rezultatų vyrauja nuo 0,51 iki 0,98. Toks atotrūkis tarp šių parametrų sudaro tinkamas ir pagrịstas sąlygas išrykinti tinkamiausias DSPM metodų poras kiekvienu AT paskirties keitimo atveju.

Apskaičiuotos aukštos $\widetilde{R}(0,80)$ ir medianos $M d(0,85)$ reikšmès (skirtumas lygus $5,8 \%$ ) sudaro prielaidas teigti, kad DSPM metodų taikymas yra tinkamas būdas vertinti AT paskirties keitimo scenarijams tinkamiausias miesto teritorijas.

Šių duomenų užtenka norint suformuoti teorinio AT antrinio naudojimo strategijos modelị (3.13 pav., toliau - Strategija).

Strategija apibrèžia pagrindines miesto ilgalaikio strateginio planavimo gaires, kurios turi būti rengiamos suderinant sprendinius su miesto BP. Strategija numato 
ir apibrěžia šešias Vilniaus miesto plètros kryptis skirtingu paskirties keitimo scenarijų $T_{1-6}$ atvejais, išlaikant AT sutvarkymo koncepcijos (2.24 pav.) principus.
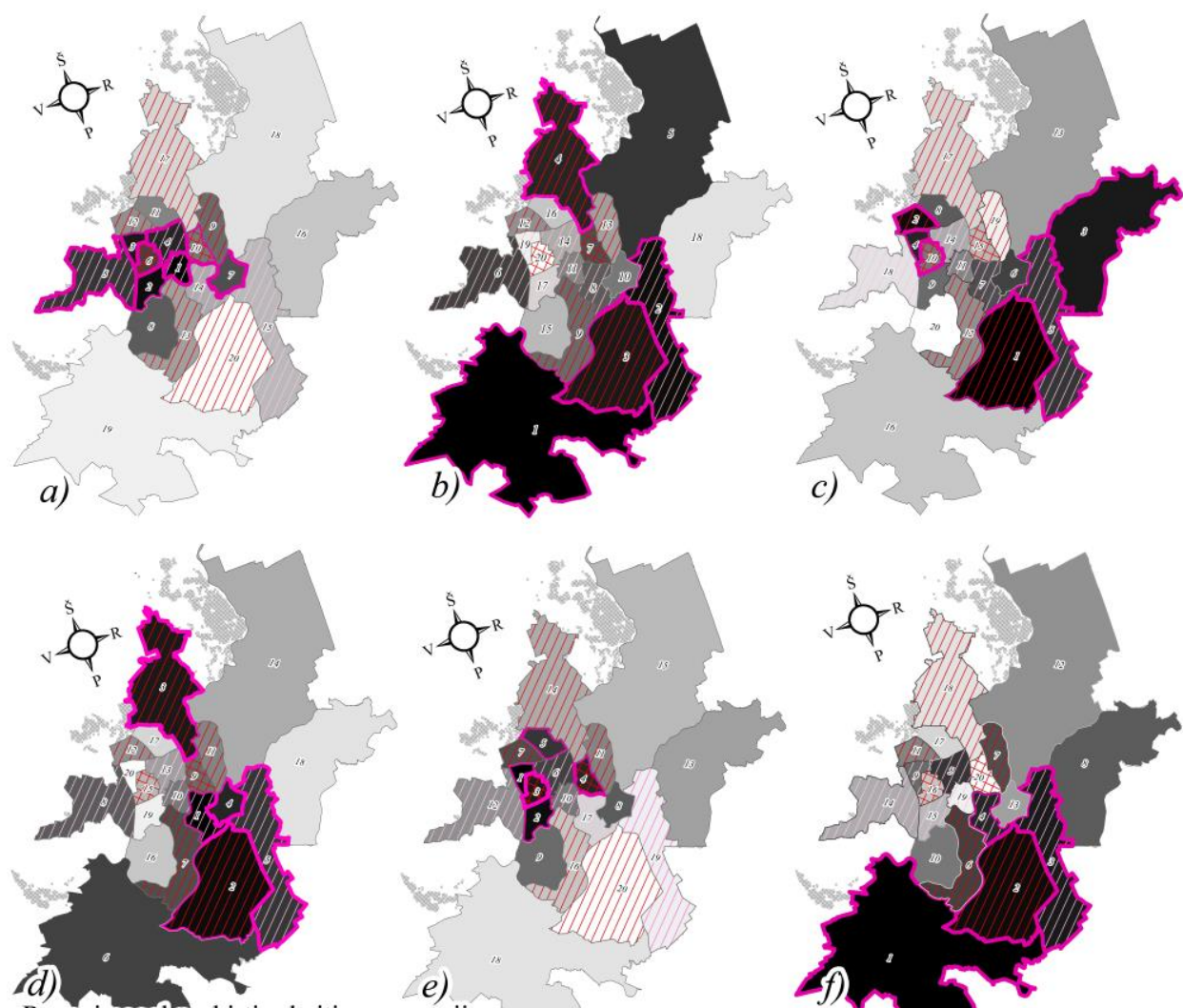

Rangai pagal paskirties keitimo scenarijų

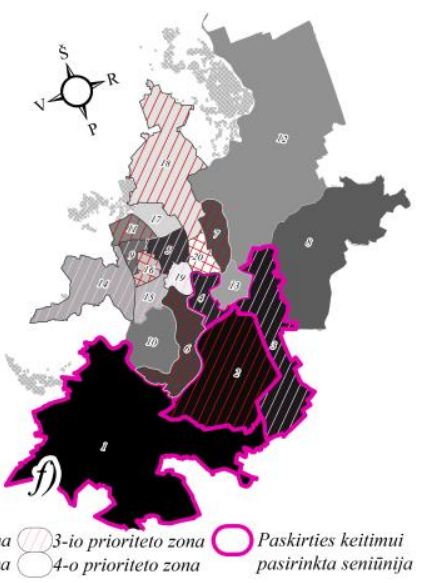

3.13 pav. Strategija skirtingais apleistų teritorijų paskirties keitimo scenarijų $T_{i}$ atvejais Vilniaus mieste: a) $\mathfrak{i}$ žaliasias zonas; b) $\mathfrak{i}$ komercinès paskirties teritorijas; c) $i$ rekreacinès paskirties teritorijas; d) i pramoninès paskirties teritorijasl e) i gyvenamosios paskirties teritorijas; f) rezervavimas miesto ateities reikmėms (sudaryta autoriaus)

Fig. 3.13. The implementation of the Strategy in different cases of scenarios $T_{i}$ for changes in brownfield land purpose in Vilnius: a) to green area; b) to commercial area; c) to recreational activity area; d) to industrial area; e) to residential area; f) to city's land reserve (created by author)

Mieste esančių AT paskirties keitimas į žaliąsias zonas $\left(T_{1}\right)$ labiausiai atitinka Žvėryno seniūnijos $\left(D_{19}\right)$ aplinkos parametrus. Šiuo atveju šis scenarijus suteiks 
daugiausia pridètinès vertės ekologiniu požiūriu. Antroji pagal tinkamumą šiam scenarijui - Karoliniškių seniūnija $\left(D_{14}\right)$. Trečioji - Justiniškių $\left(D_{9}\right)$ seniūnija.

AT paskirties keitimas ì komercinę $\left(T_{2}\right)$ Vilniaus miesto atveju labiausiai atitinka Paneriu $\left(D_{8}\right)$ seniūnijos ekonominès grupès parametrus. Antroji ir trečioji pagal tinkamumą šiam AT scenarijui nustatytos kitos periferinëje miesto dalyje esančios seniūnijos - Rasos $\left(D_{1}\right)$ ir Naujininkų $\left(D_{3}\right)$.

Paskirties keitimas i rekreacines zonas $\left(T_{3}\right)$ grịstas greta centrinès miesto dalies ir šiaurès vakarų bei šiaurès rytų periferinese miesto dalyse esančių AT sutvarkymu. Labiausiai šio AT paskirties keitimo scenarijaus rodiklius $C_{E, U, S, N}$ atitinka Naujininkų $\left(D_{3}\right)$, Pašilaičių $\left(\mathrm{D}_{5}\right)$ ir Naujosios Vilnios $\left(\mathrm{D}_{7}\right)$ seniūnijos gamtinès ir socialinès aplinkos parametrai. Atsižvelgiant ị prioritetiškumo laipsnị $\operatorname{Pr}$, AT paskirties keitimo procesai turi būti pradedami Naujininkų ir Pašilaičių, paskui Naujosios Vilnios seniūnijoje.

AT paskirties keitimas ị pramoninę $\left(T_{4}\right)$ gali būti taikomas Naujamiesčio $\left(D_{12}\right)$, Naujininkų $\left(D_{3}\right)$ ir Verkių $\left(D_{13}\right)$ seniūnijose. Atsižvelgiant ị pirminę AT paskirtị ir galimą paskirties keitimo potencialą ekonominiu požiūriu, šio AT scenarijaus prioritetinè kryptis yra pietryčių, pradedant nuo Naujamiesčio ir Naujininkų, seniūnijose esančių AT.

Remiantis atliktais skaičiavimais, AT paskirties keitimas i gyvenamają $\left(T_{5}\right)$ Vilniaus miesto atveju turi būti vykdomas šiaurinèje ir šiaurès vakarinè miesto dalyse esančiuose gyvenamuosiuse mikrorajonuose, kuriems būdingas aukštas užstatymo intensyvumas. Šio AT scenarijaus rodiklius $C_{E, U, S, N}$ atitinka Justiniškių $\left(D_{9}\right)$, Karoliniškių $\left(D_{14}\right)$, Viršuliškių $\left(D_{10}\right)$ ir Šnipiškių $\left(D_{6}\right)$ seniūnijų socialinès aplinkos parametrai. Remiantis nustatytu prioritetiškumo laipsniu, daugiausia dėmesio turi būti skiriama Viršuliškių ir Šnipiškių seniūnijoms. Šis sprendinys parodo, kad Vilniaus mieste gyvenamosios zonos turi koncentruotis $\mathfrak{i}$ atskiru teritorinių bendruomenių formavimąsi ir patogaus susisiekimo su miesto centru išlaikymą.

AT rezervavimu miesto ateities reikmėms $\left(T_{6}\right)$ grindžiamas miesto teritorijų plètros pristabdymas tose AT, kurios nagrinejjamu momentu yra ekonomiškai nenaudingos, neatitinka miesto plètros savybių. Būtu naudingiau atidèti paskirties keitimo procesus, ịvykus natūraliems miesto posistemių parametrų pokyčiams ilgalaikèje 5-10 metu perspektyvoje. Skaičiavimai parodè, kad labiausiai tokios plètros bruožus atitinka Panerių $\left(D_{8}\right)$, Naujininkų $\left(D_{3}\right)$ ir Rasų $\left(D_{1}\right)$ seniūnijos.

Nustačius skirtingiems strategijos scenarijams tas pačias vienodo rango seniūnijas, AT paskirties keitimas turi būti paskirstytas tolygiai nustatytiems scenarijams. Pavyzdžiui, Panerių seniūnija $\left(D_{8}\right)$ pagal skaičiavimų rezultatus yra tinkama igyvendinant AT paskirties keitimą i komercinę $\left(T_{2}\right)$, taip pat AT atidèjimą miesto rezervui $\left(T_{6}\right)$. Tokiu atveju apytikriai $50 \%$ turi būti taikomas $T_{2}$ ir likusiems $50 \%-T_{6}$ sprendinys. Proporcijos turi būti nustatomos arba tikslinamos atliekant papildomą ekspertizę vietovès lygmeniu. Taip pat, esant tokiam atvejui, šeštasis strategijos sprendinys laikomas silpnesnio prioriteto negu pirmieji penki. 


\subsubsection{Integruoti skirtingu apleistụ teritorijụ paskirties keitimo scenarijụ deriniai pagal planavimo pobūdị}

AT sutvarkymo koncepcija turi būti parenkama (2.23 pav.) atsižvelgiant ị miesto ypatybes, apibrèžtas prioritetines strateginio planavimo gaires ir atliktą geostatistinę analizę. Kiekvienas koncepcijas etapas turi būti vykdomas vienas po kito, pradedant nuo turinčio didžiausią prioritetą.

Esant apibrež̌toms strateginio planavimo prioritetinèms kryptims ir atsižvelgus i gautus sprendimų prièmimo rezultatus, pasiūlyti integruoti AT paskirties keitimo scenarijų rinkiniai, iggyvendinti unikaliomis miesto sąlygomis (3.12 pav.).

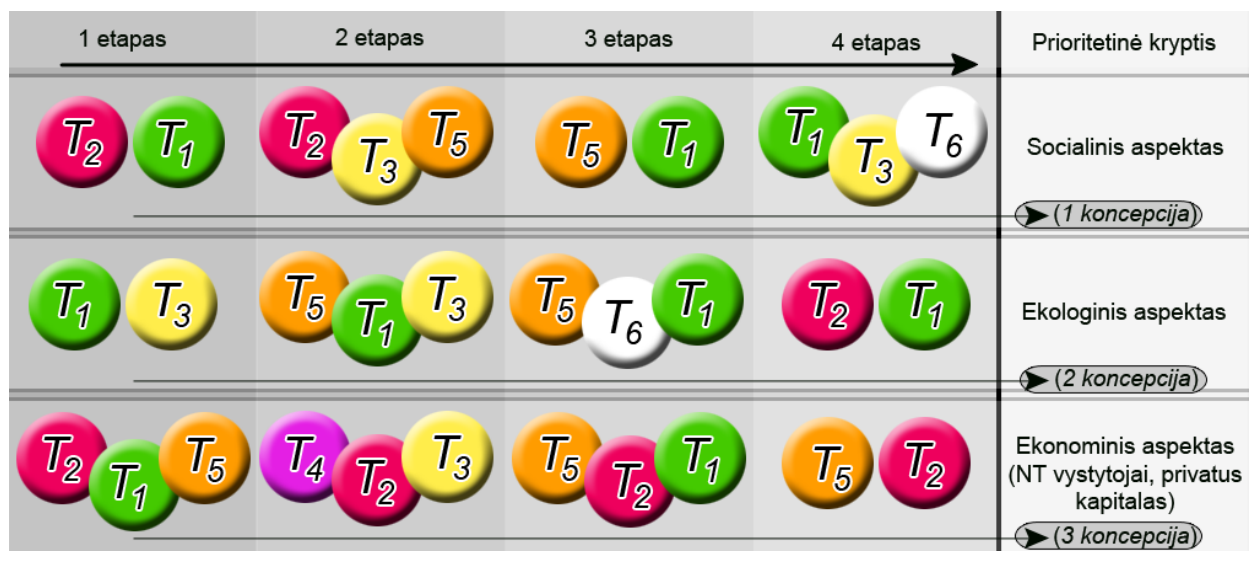

3.14 pav. Pasiūlyti apleistų teritorijų sutvarkymo koncepcijoms ịgyvendinti integruoti paskirties keitimo sprendiniai (sudaryta autoriaus)

Fig. 3.14. The suggested integrated solutions for changes in the purpose of implementing the concepts of brownfield redevelopment (created by author)

1-oje koncepcijoje ši strategijos veikimo kryptis nukreipta $\mathfrak{i}$ socialinès aplinkos gerinimą socialiai jautriausiose miesto vietovėse. Šiuo atveju pirmuoju etapu keičiama AT paskirtis didžiausiu kriminogeniniu aktyvumu pasižyminčiose miesto vietose ị komercinę paskirtị $\left(T_{2}\right)$ ir žaliujų erdvių teritorijų paskirti $\left(T_{1}\right)$. Centrinèse miesto teritorijose siūloma AT paskirtị pakeisti ị mišrią teritorijų paskirti, kur dominuoja komercinès $\left(T_{2}\right)$, rekreacinès $\left(T_{3}\right)$ ir gyvenamosios paskirties $\left(T_{5}\right)$ teritorijos. Trečiuoju etapu toliau nuo mesto centro esančiose pramoninès paskirties teritorijose siūloma mažesnès apimties AT paskirtị keisti ị žaliujų erdvių $\left(T_{1}\right)$ ir gyvenamosios paskirties teritorijų paskirtį $\left(T_{5}\right)$. Ketvirtuoju etapu, siekiant apsaugoti miesto žaliajji žiedą, AT turi būti transformuojamos ị žaliąsias $\left(T_{1}\right)$ ir rekreacines $\left(T_{3}\right)$ zonas arba paliekamos miesto rezervo reikmėms. 
2-oje koncepcijoje ši strategijos veikimo kryptis nukreipta ị ekologinės aplinkos gerinimą didžiausios esamos arba potencialios taršos miesto vietose. Šioje koncepcijoje atkreipiamas ypatingas dėmesys $\mathfrak{i}$ žaliujų miesto zonų apsaugą ir rekreacinių erdvių vystymą visais koncepcijos ịgyvendinimo etapais. Atkreipiamas dèmesys, kad žaliosios erdvès planuojamos keičiant AT paskirtị kompleksiškai kartu su komercinès paskirties teritorijomis, kad būtų padidintas teritorijos matomumas viešojo saugumo prevencijos tikslais paskutiniame koncepcijos įgyvendinimo etape. Laikantis koncepcijos gairių, žaliosios zonos $\left(T_{1,3}\right)$ turi būti planuojamos kartu su gyvenamujų zonų plètra. Tai reiškia, kad gyvenamujų zonų prieigose arba pasiekiamumo spindulio ribose dèl urboekologinès funkcijos ši koncepcija turi būti igyvendinama aukštu prioritetu. Vietovėse, kuriose yra pakankamai žaliujų plotų, šiai funkcijai tinkamos AT turi būti sutvarkomos kaip rezervinè teritorija vystyti žaliąsias ir rekreacines teritorijas ateityje $\left(T_{6}\right)$.

3-ioje koncepcijoje ši strategijos veikimo kryptis nukreipta i ekonomiškai patrauklias naujam gyvenamojo ir komercinio NT vystymui miesto vietas. Pagrindinis demesys skiriamas komercinių teritorijų vystymui $\left(T_{2}\right)$ esamose AT. Centrinèse ir teritorinių bendruomenių veikimo zonose šios koncepcijos sprendiniai derinami atsižvelgiant ị žaliujų plotų skaičių ir prieinamumą. Todẻl prireikus dalis AT turi būti keičiamos ì žaliąsias ir rekreacines zonas $\left(T_{1,3}\right)$ užtikrinant urboekologinès funkcijos veikimą gyvenamujų ir didžiausiu oro ir garso taršos lygiu pasižyminčiose teritorijų prieigose. Šios koncepcijos igyvendinimas pasižymi daugiafunkcių teritorijų plètra didžiausių gyventojų susibūrimo prieigos zonose (centriné miesto dalis, teritorinių bendruomeniu, rajonų centrai), šalia gyventojų srautus generuojančių traukos centrų. Ši koncepcija yra pagrindinė priemonè kompaktiško miesto modeliui kurti, išaugant miesto formą ir naudojant esamą socialinę bei inžinerinę infrastruktūrą rekreacinių, komercinių ir gyvenamujų erdvių prieigos zonose.

\subsection{Trečiojo skyriaus išvados}

1. Apskaičiuoti koreliacijos koeficientai išryškino stiprų priežastinį ryšį tarp apleistų teritorijų ir socialinę aplinką apibūdinančių rodiklių $\left(\right.$ Det $\left._{\text {,vid,CS }}=0,526\right)$.

2. Naudojantis atlikta mokslinès literatūros analize ir taikant ekspertinio vertinimo metodą, sudaryta hierarchinè ankstyvujų apleistų teritorijų rodiklių sistema. Šios sistemos galutinèje grandyje atrinkta 15 svarbiausių rodiklių. Jie suskirstyti ị keturias grupes pagal ekonominị, socialinị, urbanistinị ir ekologinị poveikị. 
3. Taikant Delphi metodiką, nustatytos svarbiausios apleistas teritorijas apibūdinančių rodiklių grupès paskirties keitimo scenarijams igyvendinti. Didžiausią ịtaką apleistų teritorijų paskirties keitimui ị žaliąsias erdves turi ekologinès grupès rodikliai, keitimui ị komercinių erdvių paskirti - ekonominès grupès, sporto aikštynų ir (arba) aktyvaus laisvalaikio zonų - socialinès ir urbanistinès grupès, gyvenamujų zonų - socialinès grupės rodikliai. Planuojant apleistas teritorijas kaip potencialias žemes miesto ateities reikmėms (dabartinis rezervas), svarbiausia ịvertinti vietinius gamtinius ir urbanistinius rodiklius.

4. Pritaikius daugiarodiklius sprendimų prièmimo metodus Vilniaus miesto atveju, skaičiavimais pagristi apleistų teritorijų paskirties keitimo sprendiniai: komercinių teritorijų plètrą numatyti Panerių, Rasų ir Naujininkų seniūnijose; pramoninių teritorijų plètrą Naujamiesčio, Naujininkų ir Verkių seniūnijose, strategijos igyvendinimą pradedant nuo Naujininkų ir Verkių; gyvenamujų teritoriju plètra turi būti plètojama Justiniškių, Karoliniškių ir Viršuliškių seniūnijose. Mišrios paskirties teritorijas planuoti Rasų ir Naujininkų seniūnijose tolygiai paskirstant komercines ir pramonines teritorijas.

5. Mokslinè apleistų teritorijų rodiklių analizè, sudarè sąlygas apibrèžti šešis detalizuotus Vilniaus miesto apleistų teritorijų paskirties keitimo strategijų sprendinius. Remiantis parengta strategija, apibrèžtos gairès, kuriomis remiantis apleistas teritorijas galima panaudoti kaip rezervines teritorijas, žaliąsias zonas, komercinès, rekreacinès, pramoninès ar gyvenamosios paskirties teritorijas. Tai leidžia objektyviau vertinti esamas ir būsimas apleistas teritorijas, parinkti tinkamiausius paskirties keitimo scenarijus ir juos pritaikyti kompleksiniuose teritorijų planavimo dokumentuose (bendruose ir detaliuose planuose). 


\section{Bendrosios išvados}

1. Atlikus mokslinès literatūros ir teritorijų planavimo reglamentų analizę, išryškinta apleistų teritorijų tikslingo panaudojimo problema. Matyti, kad apleistų teritorijų paskirties keitimo sprendimo igyvendinimą apsunkina teritorijų ribų neapibrèžtumas ir skirtingai literatūros šaltiniuose naudojamos sąvokos šioms teritorijoms apibūdinti. Dèl šios priežasties apleistų teritorijų paskirties keitimo galimybès vertintos tik atskirais atvejais. Atsižvelgus ị analizès rezultatus, pasiūlytas apleistos teritorijos apibrèžimas ir rūšys.

2. Išnagrinèjus mokslinèje literatūroje ir reglamentuose pateiktus apleistų teritorijų apibrèžimus, tvarkymo praktiką ir rekomendacijas, iš 152 skirtingu rodiklių, susietų pagal naudojimo prasmę ir poveikį, sudaryta hierarchiné rodiklių sistema. Atlikus rodiklių apžvalgą, joje atrinkti 15 rodikliu, pagal kuriuos apleistos teritorijos mieste gali būti vertinamos ir palyginamos tarpusavyje.

3. Atlikta geostatistinè analizè parodè, kad apleistų teritorijų kiekis skiriasi nuo oficialiai skelbiamų duomenų. Priklausomai nuo atskirose miesto seniūnijose esančio funkcinio nevienalytiškumo, apleistos teritorijos plotas skiriasi net iki 40 kartų. 
4. İrodytas priežastinis ryšys tarp apleistų teritorijų vietos mieste ir šias teritorijas apibūdinančių rodiklių reikšmių seniūnijose. Nustatyti svarbiausi veiksniai, skatinantys apleistų teritorijų plètrą. Koreliacinès analizès ir rodiklių savujų svorių skaičiavimai parodè, kad didžiausiu priežastiniu ryšiu pasižymi socialinès grupès rodikliai $(R=0,526)$. Iš jų, stipriausias koreliacinis ryšys nustatytas tarp nedarbo lygi $(R=$ $0,85)$, skurstančių gyventojų skaičių $(R=0,83)$ ir nusikalstamumo lygi seniūnijose $(R=0,83)$ apibūdinančių rodiklių.

5. Pritaikius daugiarodiklius sprendimų prièmimo metodus, nustatyti svarbiausi apleistų teritorijų rodikliai, kurie padeda priimti sprendimus dèl paskirties keitimo scenarijaus igyvendinimo. Skaičiavimai atskleidé, kad urbanistinių rodiklių grupe daro didžiausią ịtaką sprendimų prièmimui keisti apleistų teritorijų paskirtị $(\omega \%=26,7 \%)$. Keičiant jų paskirti i gyvenamosios zonos paskirti, svarbiausi tampa socialinès grupès rodikliai $\left(\omega_{\%}=34,08 \%\right)$.

6. Pritaikius daugiarodiklius sprendimų prièmimo metodus, pasiūlytas būdas nustatyti tinkamiausias miesto dalis apleistų teritorijų scenarijams igyvendinti. Apskaičiuoti ịverčiai, nusakantys paskirties keitimo scenarijaus tinkamumą seniūnijoje. Taikant ši atrankos būdą nustatyta, kad Vilniaus miesto atveju, apleistų teritorijų paskirties keitimas ị komercinès paskirties teritorijų paskirtị turi būti vykdomas Panerių seniūnijoje $(\omega=0,577)$, keičiant ì žaliųjų plotų paskirtịŽvèryno $(\omega=0,577), \quad \grave{i}$ rekreacinès paskirties - Naujininkų $(\omega=0,486)$, ì pramoninès paskirties - Pilaitè $(\omega=0,510)$, ị gyvenamosios paskirties - Justiniškių $(\omega=0,538)$ seniūnijose. Miesto teritorijos rezervui plètoti rekomenduojama naudoti Paneriu seniūnijoje $(\omega=0,589)$ esančias apleistas teritorijas. Nustatyta, kad apleistų centrinès ir vidurinès daugiaaukščio užstatymo teritorijų paskirtis turi būti keičiama ị mišrių daugiafunkcių teritorijų paskirtį.

7. Disertacijos pagrindu parengta unikali apleistų teritorijų paskirties keitimo vertinimo metodika, kuri leidžia derinant pradines rodiklių reikšmes ir galimus jų paskirties keitimo scenarijus koreguoti apleistų teritorijų atrankos modelị bei ją taikyti pasirinktam miestui. 


\section{Literatūra ir šaltiniai}

Abdullahi, S.; Pradhan, B. 2015. Sustainable Land Use Change Modelling Using GIS-based Weights-of-Evidence Approach. Applied Spatial Analysis and Policy 9(1). DOI: https://doi.org/10.1007/s12061-015-9139-1.

Adams, D.; De Sousa, C.; Tiesdell, S. 2010. Brownfield development: A comparison of North American and British approaches, Urban studies 47(1): 75-104. Prieiga per internetą: <https://www.gla.ac.uk/media/media_47883_en.pdf>.

Alexandrescu, F.; Pizzol, L.; Zabeo, A.; Rizzo, E.; Giubilato, E.; Critto, A. 2018. Identifying sustainability communicators in urban regeneration: Integrating individual and relational attributes, Journal of Cleaner Production 173: 278-291. DOI: https://doi.org/10.1016/j.jclepro.2016.09.076.

Aloini, D.; Dulmin, R.; Mininno, V.; Pellegrini, L.; Farina, G. 2018. Technology assessment with IF-TOPSIS: An application in the advanced underwater system sectorm, Technological Forecasting and Social Change 131:38-48. DOI: https://doi.org/10.1016/j.techfore.2017.07.010.

Alvarez-Guerra, M.; Viguri, J.R.; Voulvoulis, N. 2009. A multicriteria-based methodology for site prioritisation in sediment management, Environment International 35(6): 920-930. DOI: https://doi.org/10.1016/j.envint.2009.03.012.

Antucheviciene, J.; Zakarevicius, A.; Zavadskas, E. K. 2011. Measuring congruence of ranking results applying particular MCDM methods, Informatica 22(3): 319-338.

Antucheviciene, J.; Zavadskas, E. K.; Zakarevicius, A. 2012. Ranking redevelopment decisions of derelict buildings and analysis of ranking results, Journal of Economic computation and economic cybernetics studies and research 46(2): 37-62.

ArcGIS Pro. 2016. What is a z-score? What is a p-value? [Žiūrèta 2018-07-07]. Prieiga per internetą: <http://pro.arcgis.com/en/pro-app/tool-reference/spatial-statistics/what-is-a-z-score-what-is-a-pvalue.htm>. 
Attoh-Okine, N. O.; Gibbons, J. 2001. Use of belief function in brownfield infrastructure redevelopment decision making, Journal of Urban Planning and Development 127: 126-143. DOI: https://doi.org/10.1061/(ASCE)0733-9488(2001)127:3(126).

Beames, A.; Broekx, S.; Heijungs, R.; Lookman, R.; Boonen, K.; Van Geert, Y.; Dendoncker, K.; Seuntjens, P. 2015. Accounting for land-use efficiency and temporal variations between brownfields remediation alternatives in life-cycle assesment, Journal of Cleaner Production 101: 109-117. DOI: https://doi.org/10.1016/j.jclepro.2015.03.073.

Beames, A.; Broekx, S.; Schneidewind, U.; Landuyt, D.; Meulen, M.; Heijungs, R.; Seuntjens, P. 2018. Amenity proximity analysis for sustainable brownfield redevelopment planning, Landscape and Urban Planning 171: 68-79. DOI: https://doi.org/10.1016/j.landurbplan.2017.12.003.

BenDor, T. K.; Metcalf, S. S.; Paich, M. 2011. The Dynamics of Brownfield Redevelopment, Sustainability 3(6), 914-936. DOI: 10.3390/su3060914.

Benkirane, M. 2016. Geographical Database, [žiūrèta 2016-12-04]. Prieiga per internetą: <http://slideplayer.com/slide/4945014>.

Bertoméu-Sánchez, S., Camos, D., Estache, A. 2018. Do economic regulatory agencies matter to private-sector involvement in water utilities in developing countries?, Utilities Policy 50: 153-163. DOI: https://doi.org/10.1016/j.jup.2018.01.001.

Blanco, H.; Alberti, M.; Olshansky, R.; Chang, S.; Wheeler, S. M.; Randolph, J., London, J. B.; Hollander, J. B.; Pallagst, K. M.; Schwarz, T.; Popper, F. J.; Parnell, S.; Pieterse, E.; Watson, V. 2009. Shaken, shrinking, hot improverished and informal: emerging research agendas in planning, Progress in Planning 72(4): 195-250. DOI: https://doi.org/10.1016/j.progress.2009.09.001.

Blotnys, A. 2013. Vilniaus būstas planuose ir igyvendintuose projektuose. Darniosios Plètros Akademija, [žiūrèta 2014-11-25]. Prieiga per internetą: <http://dpakademija.lt/stor/uploads/2013/07/Art\%C5\%ABras-Blotnys-Vilniaus-miesto-savivaldyb\%C4\%97-Vilniaus-b\%C5\%ABstas-\%C4\%AFgyvendinami-ir-planuojami-projektai.pdf>.

Bolund, P.; Hunhammar, S. 1999. Ecosystem services in urban areas, Ecological Economics 29(2): 293-301, [žiūrèta 2015-04-24]. ]Prieiga per internetą: <http://www.fao.org/uploads/media/Ecosystem_services_in_urban_areas.pdf $>$.

Burinskienè, M.; Jakovlevas-Mateckis, K.; Adomavičius, V. 2003. Subalansuota miestu plètra. Vilnius: Technika, 251 p. ISBN 9986056640.

Bürger, C. M.; Bayer, P.; Finkel, M. 2007. Algorithmic funnel-and-gate system design optimization, Water Resources Research 43 (W08426): 1-19. DOI: 10.1029/2006WR005058.

Butkus, T. S. 2011. Miestas kaip ịvykis. Urbanistine kultūriniu funkciju studija. Vilnius: Kitos knygos, 123 p. ISBN 9786094270352.

CABERNET (Concerted Action on Brownfield and Economic Regeneration). 2007. The Scale and Nature of European Brownfields, [žiūrèta 2014-03-21]. Prieiga per internetą: <www.cabernet.org.uk/resourcefs/417.pdf>.

CEEP. 2014. Brownfields: From Redevelopment to Revitalization, [žiūrèta 2015-11-11]. Prieiga per internetą: <http://ceep.udel.edu/?s=Brownfields\%3A+From+Redevelopment+to+Revitalization>.

Centrinè projektų valdymo agentūra [Central Project Management]. 2014, [žiūrèta 2014-10-22]. Prieiga per internetą: 〈http://www.ppplietuva.lt/projektai>.

Céspedes Restrepo, J.; Morales-Pinzón, T. 2018. Urban metabolism and sustainability: Precedents, genesis and research perspectives, Resources, Conservation and Recycling 131: 216-224. DOI: https://doi.org/10.1016/j.resconrec.2017.12.023.

Chen, W.; Peng, J.; Hong, H.; Shahabi, H.; Pradhan, B.; Liu, J.; Zhu, A.; Pei, X.; Duan, Z. 2018. Landslide susceptibility modelling using GIS-based machine learning techniques for Chongren 
County, Jiangxi Province, China, Science of The Total Environment 626: 1121-1135. DOI: https://doi.org/10.1016/j.scitotenv.2018.01.124.

Chiesura, A. 2004. The role of urban parks for the sustainable city. Landscape and Urban Planning 68 (1): 129-138. DOI: https://doi.org/10.1016/j.landurbplan.2003.08.003.

Chrysochoou, M.; Brown, K.; Dahal, G.; Granda-Carvajal, C.; Segerson, K.; Garrick, N.; Bagtzoglou, A. 2012. A GIS and indexing scheme to screen brownfield for area-wide redevelopment planning, Landscape and Urban Planning 105: 187-198. DOI: http://dx.doi.org/10.1016/j.landurbplan.2011.12.010.

Copraman project. 2012. [online], [cited 3 May 2015]. Internet access: http://cobraman.vsb.cz.

Couch, Ch.; Sykes, O.; Börstinghaus, W. 2011. Thirty years of urban regeneration in-Britain, Germany and France: The importance of context and path dependency, Progress in Planning 75(1): 1-52. DOI: https://doi.org/10.1016/j.progress.2010.12.001.

Critto, A.; Cantarella, L.; Carlon, C.; Giove, S.; Petruzzelli, G.; Marcomini, A. 2006. Decision support-oriented selection of remediation technologies to rehabilitate contaminated sites, Integrated environmental assessment and management 2(3): 273-285.

CTLS. 2011. Reversing Urban Sprawl: A Reclaimability Index Approach for Reviving Downtown Brownfields, [online], [žiūrèta 2015-10-11]. Prieiga per internetą: <http://www.ctls.uconn.edu/ research/completed-projects>.

Čekanavičius, V.; Murauskas, G. 2004. Statistika ir jos taikymai. II. Vilnius: TEV, 271 p. ISBN 9955491167.

Černiauskas, Š. 2014. Aukso vertès laukymė miesto pakraštyje: Vilniaus valdžia netiki savo akimis, Delfi.lt., [žiūrèta 2015-02-10]. Prieiga per internetą: <http://www.delfi.lt/news/daily/lit-huania/auksovertes-laukyme-miesto-pakrastyje-vilniaus-vald-zia-netiki-savo-akimis.d?id=66067032 > .

De Meirleir, M. 2012. Location, Location, Location. A plant Location and Site Selection Guide. Abingdon: Routledge, 184 p. ISBN 9781136409035.

De Vivo, B.; Lima A. 2018. Chapter 15 - The Bagnoli-Napoli Brownfield Site in Italy: Before and After the Remediation, Environmental Geochemistry (Second Edition), Site Characterization, Data Analysis and Case Histories: 389-416. DOI: https://doi.org/10.1016/B978-0-444-63763-5.00008-2.

Deilmann, C.; Hennersdorf, J.; Lehmann, I.; Reißmann, D. 2018. Data envelopment analysis of urban efficiency - Interpretative methods to make DEA a heuristic tool, Ecological Indicators 84: 607-618. DOI: https://doi.org/10.1016/j.ecolind.2017.09.017.

Del Sasso, P.; Caliandro, L. P. 2010. The role of historical agroindustrial buildings in the study of rural territory, Landscape and Urban Planning 96(3): 146-162. DOI: 10.1016/j.landurbplan.2010.03.003.

Donaldson, R., Lord, R. 2018. Can brownfield land be reused for ground source heating to alleviate fuel poverty?, Reneweable Energy 116(A): 344-355. DOI: https://doi.org/10.1016/j.renene.2017.09.037.

Dotzour, M. 2002. Groundwater contamination and residential property values, in: Roddewig, R. J. (Ed.). Valuing Contaminated Properties. Illinois: The Appraisal Institute, 398-405. ISBN 9780922154715.

Doumpos M.; Zopounidis C. 2002. Multicriteria decision aid classification methods. Berlin: Springer Science \& Business Media, 256 p. ISBN 9781402008054.

Drèmaitè, N. 2004. Fabrikas kaip modernizmo architektūros simbolis, Urbanistika ir Architektūra 28(1): 25-31.

Duerr, I.; Merril, H.; Wang, C.; Bai, R.; Boyer, M.; Dukes, M.D.; Bliznyuk, N. 2018. Forecasting urban household water demand with statistical and machine learning methods using large space- 
time data: A Comparative study, Environmental Modelling \& Software 102: 29-38. DOI: https://doi.org/10.1016/j.envsoft.2018.01.002.

EPA's Smart Growth Index in 20 Pilot Communities. 2003. Using GIS Sketch Modelling to Advance Smart Growth [online], [žiūrèta 2015-10-05]. Prieiga per internetą: <http://www2.epa.gov/smart-growth/smart-growthindex>.

Eremenko, K. 2018. Confident Data Skills. Great Britain: Kogan Page, 257 p.

Erener, A.; Mutlu, A.; Düzgün, S. 2016. A comparative study for landslide susceptibility mapping using GIS-based multi-criteria decision making analysis (MCDA), logistic regression (LR) and association rule mining (ARM), Energy Geology, Special Issue on Probabilistic and Soft Computing Methods for Engineering Geology 203: 45-55. DOI: http://dx.doi.org/10.1016/j.enggeo.2015.09.007.

Ertel, T.; Schug, B.; Geffers, G. 2008. REVIT - Revitalising Industrial Sites. Towards More Effective and Sustainable Brownfields Revitalisation Policies, Proceedings of ConSoil 2008, Milan.

EUGRIS: Portal for soil and water management in Europe. 2005. REVIT Towards more effective and sustainable brownfield revitalisation policies. European Commission, $5^{\text {th }}$ Framework Programme, [online], [žiūrèta 2017-12-22]. Prieiga per internetą: <http://www.eugris.info/displayproject.asp? Projectid $=4509>$.

European Commission. 2010. Regions for economic change conference 2010. Workshop on Reusing Bronfields Sites and Buildings, 21 May 2010, Brussels.

European Commission. 2013. Thematic Issue: Brownfield Regeneration. Issue 39, [online], [cited 11 May 2017]. Internet access: http://ec.europa.eu/environment/integration/research/newsalert/ pdf/39si_en.pdf.

Frantal, B.; Greer-Wootten, B.; Klusaček, P.; Krejči, T.; Kunc, J.; Martinat, S. 2015. Exploring spatial pattern of urban brownfields regeneration: The case of Brno, Czech Republic, Cities 44: 9-18. DOI: http://dx.doi.org/10.1016/j.cities.2014.12.007.

Garcia-Ayllon, S. 2018. Urban transformations as indicators of economic change in post-communist Eastern Europe: Territorial diagnosis through five case studies, Habitat International 71: 29-37. DOI: https://doi.org/10.1016/j.habitatint.2017.11.004.

Garcia-Palomares, J. C.; Gutiérrez, J.; Mínguez, C. 2016. Identification of tourist hot spots based on social networks: A comparative analysis of European metropolises using photosharing services and GIS, Applied Geography 63: 408-417. DOI: http://dx.doi.org/10.1016/j.apgeog.2015.08.002.

Geddes, R.R., Reeves, E. 2017. The favourability of U.S. PPP enabling legislation and private investment in transportation infrastructure, Utilities Policy 48: 157-165. DOI: https://doi.org/10.1016/j.jup.2017.07.002.

Ginevicius, R.; Podvezko, V.; Podviezko, A. 2012. Evaluation of Isolated Socio-Economical Processes by a Multi-Criteria Decision Aid Method ESP, in: Ginevicius, R.; Rutkauskas, A. V.; Stankeviciene, J. (eds.). The 7th International Scientific Conference Business and Management'2012. Selected papers. Vilnius: Technika, 1083-1088.

Ginevicius, R.; Podvezko, V.; Podviezko, A.; Ginevicius, T. 2013. On Creating a System of Criteria for Multiple Criteria Evaluation Using Methods of Mathematical Statistics, in: Zavadskas, E. K.; Vilutiene, T.; Tamosaitiene, J. (Eds.). The 14th German-Lithuanian-Polish colloquium on Innovative solutions in construction technology and management. Vilnius: Technika.

GIS Resources. 2014. Types of Interpolation Methods, [žiūrèta 2017-12-23]. Prieiga per internetą: <http://www.gisresources.com/types-interpolation-methods_3>.

Glumac, B.; Han, Q.; Schaefer, W.; van der Krabben, E. 2015. Negotiation issues in forming publicprivate partnerships for brownfield redevelopment: Applying a game theoretical experiment, Land Use Policy 47: 66-77. DOI: https://doi.org/10.1016/j.landusepol.2015.03.018. 
Green, K. C.; Amstrong, J. S.; Graefe, A. 2007. Methods to elicit forecast from groups: Delphi and prediction markets compared. Foresight: The International Journal of Applied Forecasting 8(1): 17-20.

Green, T.L. 2018. Evaluating predictors for brownfield redevelopment, Land Use Policy 73: 299-319. DOI: https://doi.org/10.1016/j.landusepol.2018.01.008.

Grimsey, D.; Lewis, M.K. 2002. Evaluating the risks of public private partnerships for infrastructure projects, International Journal of Project Management 20: 107-118. DOI: http://dx.doi.org/10.1016/S0263-7863(00)00040-5.

Griškevičiūtè-Gečienè, A., Griškevičienè, D. 2016. The Influence of Transport Infrastructure Development on Sustainable Living Environment in Lithuania, Proceedia Engineering 134: 215-223. DOI: https://doi.org/10.1016/j.proeng.2016.01.062.

Gudienė, N.; Banaitis, A.; Podvezko, V.; Banaitienè, N. 2014. Identification and evaluation of the critical success factors for construction projects in Lithuania: AHP approach, Journal of Civil Engineering and Management 20(3): 350-359. DOI: https://doi.org/10.3846/13923730.2014.914082.

Guzmán, F.; Sierra, V. 2012. Public-private collaborations: Branded public services? European Journal of Marketing 46 (7/8): 994-1012. DOI: https://doi.org/10.1108/03090561211230160.

Habibi, A.; Jahantigh, F. F.; Sarafrazi, A. 2015. Fuzzy Delphi Technique for Forecasting and Screening Items, Asian Journal of Research in Business Economics and Management 5(2): 130-143. DOI: 10.5958/2249-7307.2015.00036.5.

Håkansson, I. 2017. The socio-spatial politics of urban sustainability transitions: Grassroots initiatives in gentrifying Peckham, Environment Innovation and Societal Transitions. DOI: https://doi.org/10.1016/j.eist.2017.10.003.

Hallsworth, A.; Coca-Stefaniak, J.A. 2018. National high street retail and town centre policy at a cross roads in England and Wales in Cities. DOI: https://doi.org/10.1016/j.cities.2018.03.002.

HOMBRE. 2013. Holistic Management of Brownfield Regeneration Early Indicators for Brownfield origination. 7th EC Framework Programme, [žiūrèta 2015-05-25]. Prieiga per internetą: <http://www.zerobrownfields.eu>.

Hwang, C. L.; Lin, M.-J. 1987. Group Decision Making under Multiple Criteria: Methods and Applications. Berlin-Heidelberg: Springer, 400 p. ISBN 9783642615801.

Hwang, C. L.; Yoon, K. 1981. Multiple attribute decision-making methods and applications. A state of the art survey, Berlin: Springer-Verlag, 269 p. ISBN 9783540105589.

Jackson, J. B.; Finka, M.; Hermann, G.; Kliučininkas, L.; Lemešenoka, N.; Petriková, D.; Pletnická, J.; Teirumnieks, E.; Velykienè, D.; Vojvodíková, B.; Zahnašová, M.; Zubková, M. 2010. Apleistos teritorijos - Vadovas: Tarp-disciplinine mokomoji priemoné, skirta apleistu teritoriju atstatymui Latvijoje ir Lietuvoje. Ostrava: Ostravos technikos universitetas, 131 p.

Jacquet-Lagreze, E.; Siskos, J. 1982. Assessing a set of additive utility functions for multicriteria decision-making, the UTA method, European journal of operational research, 10(2): 151-164. DOI: https://doi.org/10.1016/0377-2217(82)90155-2.

Jakimavicius, M.; Burinskiene, M.; Gusaroviene, M.; Podviezko, A. 2016. Assessing multiple criteria for rapid bus routes in the public transport system in Vilnius, Public Transport 8(3): 365-385. DOI: http://dx.doi.org/10.1007/s12469-016-0146-7.

Kaklauskas, A.; Zavadskas, E. K.; Bardauskienė, D. 2012. Darnus nekilnojamojo turto vystymas. Vilnius: Technika, 880 p. ISBN 9786094571985.

Kaufman, M. M.; Rogers, D. T.; Murray, K. S. 2005. An empirical model for estimating remediation costs at contaminated sites, Water, Air, and Soil Pollution 167: 365-386. DOI: http://dx.doi.org/10.1007/s11270-005-0214-0. 
Keller, S. 2011. Social Psychology and Philosophy: Problems in Translation, Nous 45(4): 776-791. DOI: 10.1111/j.1468-0068.2010.00818.x.

Kendall, M. G. 1975. Rank Correlation Methods, 4th. edition. London: Charles Griffin, 272 p. ISBN 978-0195208375.

Kendall, M. G.; Gibbons, J. D. 1990. Rank correlation methods. 5th ed. New York: Oxford University Press, 260 p. ISBN 9780195205725.

Keshavarz Ghorabaee, M.; Zavadskas, E. K.; Olfat, L.; Turskis, Z. 2015. Multi-Criteria Inventory Classification Using a New Method of Evaluation Based on Distance from Average Solution (EDAS), Informatica 26(3): 435-451. DOI: http://dx.doi.org/10.15388/Informatica.2015.57.

Kilgour, D. M.; Chen, Y.; Hipel, K. W. 2010. Multiple Criteria Approaches to Group Decision and Negotiation, in: Ehrgott, M.; Figueira, J. R.; Greco, S. (Eds.). Trends in Multiple Criteria Decision Analysis. Boston: Springer, 317-338. ISBN 9781441959041.

Kimmelman, M. 2014. The Climax in a Tale of Green and Gritty. The High Line Opens Its Third and Final Phase. The New York Times, [žiūrèta 2015-07-12]. Prieiga per internetą: <https://www.nytimes.com/2014/09/20/arts/design/the-high-line-opens-its-third-and-final-phase.html>.

Klusáček, P.; Alexandrescu, F.; Osman, R.; Malýa, J.; Kunc, J.; Dvořák, P.; Frantál, B.; Havlíček, M.; Krejčía, T.; Martinát, S.; Skokanová, H.; Trojan, J. 2018. Good governance as a strategic choise in brownfield regeneration: Regional dynamics from the Czech Republik, Land Use Policy 73: 29-39. DOI: https://doi.org/10.1016/j.landusepol.2018.01.007.

Koch, F., Bilke, L., Helbig, C., Schlink, U. 2018. Compact or cool? The impact of brownfield redevelopment on inner-city micro climate, Sustainable Cities and Society 38: 31-41. DOI: https://doi.org/10.1016/j.scs.2017.11.021.

Koppenjan, J. F. M.; Enserink, B. 2009. Public-private partnerships in urban infrastructures: reconciling private sector participation and sustainability, Public Administration Review 69: 84-296. DOI: https://doi.org/10.1111/j.1540-6210.2008.01974.x.

Krejčí, T., Dostál, I., Havlíček, M., Martinát, S. 2016. Exploring the hidden potential of sugar beet industry brownfields (case study of the Czech Republic), Transportation Research Part D: Transport and Environment 46:284-297. DOI: https://doi.org/10.1016/j.trd.2016.04.006.

Kuliešis, G.; Šalengaitė, D.; Kozlovskaja, A. 2011. Apleista Žemé: problemos ir sprendimo būdai. Mokslo studija. Vilnius: Lietuvos Agrarinès Ekonomikos Institutas, 53 p. ISBN 9789955481256.

Kumar, L., Jindal, A., Velaga, N.R. 2018. Financial risk assessment and modelling of PPP based Indian highway infrastructure projects, Transport Policy 65: 2-11. DOI: https://doi.org/10.1016/j.tranpol.2017.03.010.

Lange, D. A., McNeil, S. 2004. Brownfield development: tools for stewardship, Journal of Urban Planning and Development 130(2): 109-116. DOI: https://doi.org/10.1061/(ASCE)07339488(2004)130:2(109).

Laprise, M., Lufkin, S., Rey, E. An operational monitoring tool facilitating the transformation of urban brownfields into sustainable neighborhoods, Building and Environment (Available online 5 June 2018). DOI: https://doi.org/10.1016/j.buildenv.2018.06.005.

Laurinènaitè-Šimelevičienè, J. 2012. Išsiplètusi viešoji Lietuvos infrastruktūra - ne mūsų kišenei? Veidas 38(2012-09-17).

Leitanaitė, R. 2010. Post-industrinis scenarijų mezginys prie Vilniaus senamiesčio, [žiūrèta 2016-05-11]. Prieiga per internetą: <http://old.architektusajunga.lt/skaitiniai/scenariju-mezginyspost-industrinei-demei-prie-vilniaus-senamiescio>.

Leitanaite, R. 2007. Teritorijų konversija Vilniaus miesto kontekste pagal bendrojo plano 2015 metams sprendinius, Urbanistika ir architektūra = Town Planning and Architecture 31(3): 131-139. 
Li, X., Yang, H., Li, W., Chen, Z. 2018. Public-private partnership in residential brownfield redevelopment: case studies of Pittsburgh, International Conference on Sustainable Design, Engineering and Construction, Proceedia Engineering 145(2016): 1534-1540. DOI: https://doi.org/10.1016/j.proeng.2016.04.193.

Lietuvos statistikos departamentas. 2018. Tarptautinè ir vidaus migracija, [žiūrèta 2018-05-27]. Prieiga per internetą: <https://osp.stat.gov.lt/statistiniu-rodikliu-analize?hash=ac45e880-29124156-b678-040dc9eed305\#>.

Limasset, E., Pizzol, L., Merly, C., Gatchett, A.M., Le Guern, C., Martinat, S., Klusáček, P., Bartke, S. 2018. Points of attention in designing tools for regional brownfield prioritization, Science of The Total Environment 622-623: 997-1008. DOI: https://doi.org/10.1016/j.scitotenv.2017.11.168.

Ling, K. 2008. Exploring the Potential Application of Brownfield Redevelopment in Dalian, China; Based on Municipal Experiences in Ontario, Canada. A thesis. Waterloo: University of Waterloo.

Linkov, I., Satterstrom, F. K.; Kiker, G.; Batchelor, C.; Bridges, T.; Ferguson, E. 2006. From comparative risk assessment to multi-criteria decision analysis and adaptive management: recent developments and applications, Environment International 32: 1072-1093. DOI: https://doi.org/10.1016/j.envint.2006.06.013.

Liverpool City Council. 2011. Key statistic and data. Cencus, [žiūrèta 2016-12-14]. Prieiga per internetą: 〈http://liverpool.gov.uk/council/key-statistics-and-data/census〉.

Liverpool City Region: Local Enterprise Partnership. 2016. Liverpool City Region Innovation Plan. 2014-2020, [žiūrèta 2016-03-17]. Prieiga per internetą: <https://www.liverpoollep.org/wpcontent/uploads/2015/06/wpid-lcr-innovation-plan-draft2014.pdf $>$.

Loures, L.; Vaz.; E. 2018. Exploring expert perception towards brownfield redevelopment benefits according to their typology, Habitat International 72: 66-76. DOI: https://doi.org/10.1016/j.habitatint.2016.11.003.

LR Aplinkos ministerija. 2014. İsakymas dèl teritorijų planavimo normų patvirtinimo, [žiūrèta 2014-01-02]. Prieiga per internetą: <https://www.etar.lt/rs/legalact/cb52bff0783311e38f91e655960bc309/transcript>.

Lwin, K. K.; Murayama Y.; Mizutani, C. 2012. Quantitative versus Qualitative Geospatial Data in Spatial Modelling and Decision Making, Journal of Geographic Information System 4(3): 237-241. DOI: http://dx.doi.org/10.4236/jgis.2012.43028.

MacCrimmon, K.R. 1968. Descriptive and Normative Implications of the Decision-Theory Postulates, Risk and Uncertainty: 3-32. International Economic Association Conference Volumes: 1-50. DOI: https://doi.org/10.1007/978-1-349-15248-3_1.

Maliene, V.; Durney-Knight, N.; Sertyesilisik, B.; Malys, N. 2012. Challenges and Opportunities in Developing Sustainable Communities in the North West of England, Challenges 3: 133-152. DOI: http://dx.doi.org/10.3390/challe3020133.

Maliene, V.; Wignall, L.; Malys, N. 2012. Brownfield Regeneration: Waterfront Site Development in Liverpool and Cologne, Journal of Environmental Engineering and Landscape Management 20(1): 5-16. DOI: https://doi.org/10.3846/16486897.2012.659030.

Marinescu, E. I.; Avran, S. 2011. Evaluation of urban fragmentation in Craiova city, Romania, Procedia Environmental Sciences 14(2012): 207-215. DOI: https://doi.org/10.1016/j.proenv.2012.03.020.

Markevicius, N.; Podviezko, A. 2014. Trademarks, trade names and brands as a measure of local, regional and global competition, in: Loster T.; Pavelka T. (Eds.). The 8th International Days of Statistics and Economics, Prague, September 11-13, 2014, Conference Proceedings. Prague: University of Economics, 1006-1015. ISBN 9788087990025. 
Martinat, S.; Dvorak, P.; Frantal, B.; Klusacek, P.; Kunc, J.; Navratil, J.; Osman, R.; Tureckova, K.; Reed, M. 2016. Sustainable urban development in a city affected by heavy industry and mining? Case study of brownfields in Karvina, Czech Republic, Journal of Cleaner Production 118: 78-87. DOI: https://doi.org/10.1016/j.jclepro.2016.01.029.

Martinat, S., Navratil, J., Hollander, J.B., Trojan, J., Klapka, P., Klusacek, P., Kalok, D. 2018. Rereuse of regenerated brownfields: Lessons from an Eastern European post-industrial city, Journal of Cleaner Production 188: 536-545. DOI: https://doi.org/10.1016/j.jclepro.2018.03.313.

Mathey, J., Arndt, T., Banse, J., Rink, D. Public perception of spontaneous vegetation on brownfields in urban areas - Results from surveys in Dresden and Leipzig (Germany), Urban Forestry \& Urban Greening 29: 384-392. DOI: https://doi.org/10.1016/j.ufug.2016.10.007.

Masson, V. 2018. Impacts of Global Changes in Cities, Encyclopedia of the Anthropocene 2: 467474. DOI: https://doi.org/10.1016/B978-0-12-809665-9.09773-1.

Matos, P.V.; Cardadeiro, E.; Amando da Silva, J.; Fernanes De Muylder, C. 2018. The use of multicriteria analysis in the recovery of abandoned mines: a study of intervention in Portugal, RAUSP Management Journal 53(2): 214-224. DOI: https://doi.org/10.1016/j.rauspm.2017.06.005.

Matulevičius, K.; Šliogerienė, J. 2011. Industrinių teritorijų konvercija: užsienio šalių praktika, iš: 14-osios Lietuvos jaunųjų mokslininkų konferencijos „Mokslas - Lietuvos ateitis“ 2011 metų teminès konferencijos „Statyba“ straipsnių rinkinys. Vilnius: Technika. ISBN 9789955289296.

Mekdjian, S. 2018. Urban artivism and migrations. Disrupting spatial and political segregation of migrants in European cities, Cities 77: 39-48. DOI: https://doi.org/10.1016/j.cities.2017.05.008.

Melander, L. 2018. Scenario development in transport studies: Methodological considerations and reflections on delphi studies, Futures 96: 68-78. DOI:https://doi.org/10.1016/j.futures.2017.11.007.

Moldoveanu, M.; Franc, V. I. 2013. Urban regeneration and more opportunities for artistic expression and cultural consumption, Procedia Economic and Finance 8 (2014): 490-496. DOI: https://doi.org/10.1016/S2212-5671(14)00118-X.

Mostafavi, M. 2010. Why ecological urbanism? Why now? in Mostafavi, M.; Doherty, G. (Eds.). Ecological Urbanism. Baden: Lars Mueller Publishers, 12-56.

Morio, M.; Schädler, S.; Finkel, M. 2013. Applying a multi-criteria genetic algorithm framework for brownfield reuse optimization: Improving redevelopment options based on stakeholder preferences, Journal of Environmental Management 130: 331-346. DOI: doi:10.1016/j.jenvman.2013.09.002.

Mozuriunaite, S. 2016. Technological Factors Determining Transformation of Urban Functions in Lithuanian Cities, Procedia Engineering 161: 1899-1903. DOI: https://doi.org/10.1016/j.proeng.2016.08.748.

Mulliner, E.; Maliene, V. 2015. An Analysis of Professional Perceptions of Criteria Contributing to Sustainable Housing Affordability. Sustainability 2015, 7, 248-270. DOI: http://dx.doi.org/10.3390/su7010248.

Navratil, J.; Pícha, K.; Martinat, S.; Knotek, J.; Kucera, T.; Balounova, Z.; White Baravalle Gilliam, V. L.; Svec, R.; Rajchard, J. 2013. A model for the identification of areas favourable for the development of tourism: a case study of the Sumava Mts. and South Bohemia tourist regions (Czech Republic), Moravian Geographical Reports 21(1): 25-40. DOI: https://doi.org/10.2478/mgr-2013-0003.

Navratil, J., Picha, K., Martinat, S., Nathanail, P. C., Tureckova, K., Holesinska, A. 2018. Resident's preferences for urban brownfield revitalization: Insights from two Czech cities, Land Use Policy 76 : 224-234. DOI: https://doi.org/10.1016/j.landusepol.2018.05.013.

Newman, G.; Park, Y.; Brownman, A. M.; Jung Lee, R. 2018. Vacant urban areas: Causes and interconnected factors, Cities 72, part B: 421-429. DOI: https://doi.org/10.1016/j.cities.2017.10.005. 
Nishisato, S. 2004. Dual Scaling, in: Kaplan, D. (Ed.). The SAGE Handbook of Quantitative Methodology for the Social Sciences. Thousand Oaks: SAGE Publications, 3-25. ISBN 0761923594.

Norrman, J.; Volchko, Y.; Maring, L.; Hooimeijer, F.; Broekx, S.; Garcção, R.; Beames, A.; Kain, J. H.; Ivarsson, M.; Touchant, K. 2015. BALANCE 4P: Balancing decision for urban brownfield redevelopment. Technical report of the BALANCE 4P project of the SNOWMAN Network coordinated call IV. Gothenburg: Chalmers University of Technology, [žiūrèta 2016-12-14]. Prieiga per internetą: http://publications.lib.chalmers.se/records/fulltext/231843/local_231843.pdf.

Norvilaitė, G. 2005. Statybų bumas užvertė darbu ir architektus, Vakaru ekspresas, [žiūrèta 2014-06-23]. Prieiga per internetą: <http://www.ve.lt/naujienos/ekonomika/ekonomikosnaujienos/statybu-bumas-uzverte-darbu-ir-architektus-394145>.

Osman, R.; Mulíček, O. 2017. Urban chronopolis: Ensemble of rhythmized dislocated places, Geoforum 85: 46-57. DOI: https://doi.org/10.1016/j.geoforum.2017.07.013.

Pakalnis, M. 2014. Konversija - mada ar neišvengiamybė? [Žiūrèta 2014-12-10]. Prieiga per intenetą: <http://ntpa.lt/wp-content/uploads/2014/12/Mindaugas-Pakalnis-Konversija-mada-arneisvengiamybe.pdf $>$.

Palevicius, V.; Grigonis, V.; Podviezko, A.; Barauskaite, G. 2016. Developmental analysis of parkand-ride facilities in Vilnius, PROMET - Traffic \& Transportation 28(2): 165-178. DOI: http://dx.doi.org/10.7307/ptt.v28i2.1767.

Palevicius, V.; Sivilevicius, H.; Podviezko, A.; Griskeviciute-Geciene, A.; Karpavicius, T. 2017. Evaluation of park and ride facilities at communication corridors in a middle-sized city, Economic Computation \& Economic Cybernetics Studies \& Research 51(2): 231-248.

Parfenova, L.; Pugachev, A.; Podviezko, A. 2016. Comparative analysis of tax capacity in regions of Russia, Technological and Economic Development of Economy 22(6): 905-925. DOI: https://doi.org/10.3846/20294913.2016.1216019.

Paul Bardos, R., Jones, S., Stephenson, I., Menger, P., Beumer, V., Neonato, F., Maring, L., Ferber, U., Track, T., Wendler, K. 2016. Optimising value from the soft re-use of brownfield sites, Science of The Total Environment 563-564: 769-782. DOI: https://doi.org/10.1016/j.scitotenv.2015.12.002.

Petersen, J.P., Heurkens, E. 2018. Implementing energy policies in urban development projects: The role of public planning authorities in Denmark, Germany and the Netherlands, Land Use Policy 76 : 275-289. DOI: https://doi.org/10.1016/j.landusepol.2018.05.004.

Petríková, D.; Vojvodíková, B.; Samson, N.; Jackson, J.B.; Finka, M.; Toptchiyski, S.; Rusu, O.C.; Zúbkoá, M.; Grigorovschi, M.; Ladzianska, Z.; Toptchiyska, D.; Pletnická, J.; Jamečný, Ĺ.; Ciolacu, D.; Jaššo, M.; Bláha, P.; Maturová, M.; Lukš, J.; Kralchevska, A.; Murínová, T.; Bergatt, W. 2012. Brownfields - Handbook BROWNTRAINS, VŠB-Technical University of Ostrava. ISBN 9788024828930.

Podvezko, V. 2005. Ekspertų įverčių suderinamumas, Ükio technologinis ir ekonominis vystymas 9(2): 101-107. DOI: https://doi.org/10.1080/13928619.2005.9637688.

Podvezko, V. 2009. Application of AHP technique, Journal of Business Economics and Management 10(2): 181-189. DOI: https://doi.org/10.3846/1611-1699.2009.10.181-189.

Podvezko, V. 2011. The Comparative Analysis of MCDA Methods SAW and COPRAS, Inžinerine Ekonomika- Engineering Economics 22(2): 134-146. DOI: http://dx.doi.org/10.5755/j01.ee.22.2.310.

Podviezko, A. 2015. Use of multiple criteria decision aid methods in case of large amounts of data, International Journal of Business and Emerging Markets 7(2): 155-169. DOI: https://doi.org/10.1504/IJBEM.2015.068351. 
Podviezko, A.; Podvezko, V. 2014. Absolute and Relative Evaluation of Socio-Economic Objects Based on Multiple Criteria Decision Making Methods, Engineering Economics 25(5): 522-529. DOI: http://dx.doi.org/10.5755/j01.ee.25.5.6624.

Pointereau, P.; Coulon, F.; Girard, P.; Lambotte, M.; Stuczynski, T.; Ortega Sanchez, V.; Del Rio, A. 2008. Analysis of Farmland Abandonment and the Extent and Location of Agricultural Areas that are Actually Abandoned or are in Risk to be Abandoned. Ispra: Institute for Environment and Sustainability, 208 p. ISSN 1018-5593.

Polyakova, I.; Vasylyeva, E. 2016. Benefits of Public-and-private Partnership for the Creation of the Infrastructure of the Urbanized Territories in Russia, Procedia Engineering 165: 1380-1387. DOI: https://doi.org/10.1016/j.proeng.2016.11.868.

Popescu, G.; Patrascoiu, R. 2012. Brownfields sites - between abandoment and redevelopment case study: Craiova city, Human Geograpgies - Journal of Studies and Research in Human Geography 6(1): 91-97. DOI: https://doi.org/10.5719/hgeo.2012.61.91.

Pourghasemi, H.R.; Rahmati, O. 2018. Prediction of the landslide susceptibility: Which algorithm, which precision? CATENA 162: 177-192. DOI: https://doi.org/10.1016/j.catena.2017.11.022.

PPP Lietuva. 2018. Viešojo ir privataus sektorių partnerystè - projektai, [žiūrèta 2018-05-28]. Prieiga per internetą: <http://ppplietuva.lt/lt/viesojo-ir-privataus-sektoriu-partneryste/vpsp-projektai>.

Prochorskaite, A., Couch, C., Malys, N., Maliene, V. 2016. Housing Stakeholder Preferences for the "Soft" Features of Sustainable and Healthy Housing Design in the UK. Int. J. Environmental Research and Public Health 2016, 13, 111. DOI: http://dx.doi.org/10.3390/ijerph13010111.

Pueffel, C., Haase, D., Priess, J.A. 2018. Mapping ecosystem services on brownfields in Leipzig, Germany, Ecosystem Services 30(A): 73-85. DOI: https://doi.org/10.1016/j.ecoser.2018.01.011.

Rafson, H. J., Rafson, R. N. 1999. Brownfields: Redeveloping Environmentally Distressed Properties. New York: McGraw-Hill, 567 p. ISBN 9780070527683.

Rizzo, E., Pesce, M., Pizzol, L., Alexandrescu, F., Giubilato, E., Critto, A., Marcomini, A., Bartke, S. 2015. Brownfield Regeneration in Europe: Identifying Stakeholder Perceptions, Concerns, Attitudes and Information Needs, Land Use Policy 43: 437-453. DOI: https://doi.org/10.1016/j.landusepol.2015.06.012.

Rizzo, E., Pizzol, L., Zabeo, A., Giubilato, E., Critto, A., Cosmo, L., Marmomini, A. 2018. An Information System for Brownfield Regeneration: providing customised information according to stakeholders' characteristics and needs, Journal of Environmental Management 217: 144-156. DOI: https://doi.org/10.1016/j.jenvman.2018.03.059.

Roig, J.; Soriano, M. J. 2015. Public-Private Partnership for Real Estate Projects: Current Framework and New Trends, Regional and Sectoral Economic Studies 15(1): 35-44.

Rosén, L., Back, P. E., Söderqvist, T., Norrman, J., Brinkhoff, P., Norberg, T., Volchko, Y., Norin, M., Bergknut, M., Döberl, G. 2015. SCORE: a novel multi-criteria decision analysis approach to assessing the sustainability of contaminated land remediation, Science of the Total Environment 511: 621-638. DOI: https://doi.org/10.1016/j.scitotenv.2014.12.058.

Rouhani, O. M., Geddes, R., Do, V. Oliver Gao, H., Beheshtian, A. 2018. Revenue-Risk-Sharing Approaches for Public-Private Partnership Provision of Highway Facilities, Case Studies on Transport Policy (accepted manuscript). DOI: https://doi.org/10.1016/j.cstp.2018.04.003.

Rowe, G.; Wright, G. 1999. The Delphi technique asa forecasting tool: issues and analysis, International Journal of Forecasting, 15(4): 353-375.

Rügner, H.; Finkel, M.; Kaschl, A.; Bittens, M. 2006. Application of monitored natural attenuation in contaminated land management e a review and recommended approach for Europe, Environmental Science \& Policy 9(6): 568-576. DOI: 10.1016/j.envsci.2006.06.001. 
Sassi, E.; Vismara, F.; Cavadini, N. O.; Acebillo, J. 2009. Industrial areas. A survey, analysis and appraisal of the potential for conversion of disused industrial areas in Ticino, Theoretical and Empirical Researches 2(1): 95-104.

Saaty, T. L. 1967. Modern Nonlinear Equations, New York, McGraw-Hill.

Saaty, T. L. 1980. The Analytic Hierarchy Process, New York: McGraw-Hill.

Saaty, T. L. 1988. Decision making for leaders: the analytical hierarchy process for decisions in a complex world. Pittsburgh: RWS Publications, 291 p. ISBN 9780962031700.

Schädler, S.; Morio, M.; Bartke, S.; Rohr-Zänker, R.; Finkel, M. 2010. Designing sustainable and economically attractive brownfield revitalization options using an integrated assessment model, Journal of Environmental Management 92: 827-837. DOI: https://doi.org/10.1016/j.jenvman.2010.10.026.

Semenzin, E.; Critto, A.; Rutgers, M.; Marcomini, A. 2009. DSS-ERA MANIA: Decision Support System for Site-Specific Ecological Risk Assessment of Contaminated Sites, in: Marcomini, A.; Suter Il, G. W.; Critto, A. (Eds.). Decision Support Systems for Risk Based Management of Contaminated Sites. Heidelberg: Springer, 205-237. ISBN 9780387097220.

Sharma, R., Newman, P. 2018. Can land value capture make PPP's competitive in fares? A Mumbai case study, Transport Policy 64: 123-131. DOI: https://doi.org/10.1016/j.tranpol.2018.02.002.

Shaw, C.; Hurth, V.; Capstick, S.; Cox, E. 2018. Intermediaries' perspectives on the public's role in the energy transitions needed to deliver UK climate change policy goals, Energy Policy 116: 267-276. DOI: https://doi.org/10.1016/j.enpol.2018.02.002.

Sivilevičius, H. 2012. Keliu dangos tiesimo ir ju priežiūros technologijos: praktiniu darbu metodikos nurodymai. Vilnius: Technika, 103 p. ISBN 9786094573699.

Stauskis, G. 2010. Development of sustainable access to urban and peri-urban landscapes in Vilnius regional area, in: Proceedings of the 27th ECLAS conference "Cultural Landscape“, 2010 September 2-October 10. Istanbul: Istanbul Technical University, 895-905.

Stevens, D.; Dragicevic, S.; Rothley, K. 2007. iCity: a GIS-CA modelling tool for urban planning and decision making, Environmental Modelling \& Software 22: 761-773. DOI: https://doi.org/10.1016/j.envsoft.2006.02.004.

Stillwell, J.; Scholten H. J. 2001. Land Use Simulation for Europe. Dordrecht: Springer Science \& Business Media, 302 p. ISBN 9781402002137.

Strenge, D. L.; Chamberlain, P. J. 1995. Multimedia Environmental Pollutant Assessment System (MEPAS): Exposure Pathway and Human Health Impact Assessment Models. Richland: Pacific Northwest Laboratory, $180 \mathrm{p}$.

Theobald, D. M. 2014. Development and Applications of a Comprehensive Land Use Classification and Map for the US, PLoS One 9(4): e-94628. DOI: https://doi.org/10.1371/journal.pone.0094628.

TIMBRE. 2012. Tailored Improvement of Brownfield Regeneration in Europe, [žiūrèta 2015-05- 25]. Prieiga per internetą: 〈http://www.timbre-project.eu〉.

TPSIS. 2015. Lietuvos Respublikos Aplinkos ministerijos Teritorijų planavimo stebėsenos informacinè sistema, [žiūrèta 2015-02-27]. Prieiga per internetą: <https://tpsis.am.lt/lt/web/guest/9>.

United Nations ESCAP. 2011. A guidebook on public-private partnership in infrastructure. Bangkok: United Nations Economic and Social Commission for Asia and the Pacific, 76 p.

United States Environmental Protection Agency. 2011. Brownfield and Urban Agriculture: Interim Guidelines for Safe Gardening Practises, [žiūrèta 2015-01-21]. Prieiga per internetą: <https://www.epa.gov/sites/production/files/2015-09/documents/bf_urban_ag.pdf>. 
Urbonaitè, I. 2010. Uždarų slidinėjimo trasų integravimas į miesto rekreacijos sistemą, Mokslas Lietuvos ateitis / Science - Future of Lithuania 2(3): 76-77. DOI: 10.3846/mla.2010.056.

Urbonaite, I. 2011. Miesto teritorinių bendruomenių itaka rekreacinių teritorijų formavimui, Mokslas - Lietuvos ateitis / Science-future of Lithuania 3(3): 30-37. DOI: 10.3846/mla.2011.048.

Urbonaitè, I. 2012. Apleistų teritorijų reikšmè formuojant miesto rekreacijos sistemą, Mokslas Lietuvos ateitis / Science - Future of Lithuania 4(2): 97-105. ISSN 2029-2341.

U.S. EPA. 1991. Risk Assessment Guidance for Superfund: Volume 1, Human Health Evaluation Manual (Part B, Development of Risk-based Preliminary Remediation Goals), EPA/540/R-92/003. Cincinnati: US Environmental Protection Agency, 54 p.

U.S. EPA. 2003. Brownfields Definition, [žiūrèta 2014-10-10]. Prieiga per internetą: <http://epa.gov/brownfields/index.html>.

Valstybinè saugomų teritorijų tarnyba prie Aplinkos ministerijos. 2008. Apleistu pastatu likvidumo programa. Vilnius: UAB HNIT BALTIC ir UAB Statybos projektų ekspertizès centras, $159 \mathrm{p}$.

Vidal, L.-A.; Marle, F.; Bocquet, J.-C. 2011. Using a Delphi process and the Analytic Hierarchy Process (AHP) to evaluate the complexity of projects, Expert Systems with Applications 38(5): 5388-5405. DOI: https://doi.org/10.1016/j.eswa.2010.10.016.

Vilniaus miesto savivaldybès administracija. 2007. Vilniaus miesto bendrasis planas iki $2015 \mathrm{~m}$., [žiūrèta 2014-11-11]. Prieiga per internetą: <https://vilnius.lt/lt/savivaldybe/miesto-pletra/vilniausmiesto-bendrasis-planas/bendras-planas-iki-2015-m>.

Vilniaus miesto savivaldybès adminsitracija. 2011. Naujų transporto rūšių diegimo Vilniaus mieste specialusis planas, [žiūrèta 2017-09-15]. Prieiga per internetą: <http://www.vilnius.lt/lit/Nauju_transporto_ruiu_diegimo_vilniaus_m/44350>.

Vilniaus miesto savivaldybès taryba. 2015. 2014-2020 m. Vilniaus miesto integruotų teritorijų vystymo programos projektas, [žiūrèta 2015-05-14]. Prieiga per internetą: <https://www.vilnius.lt/vaktai2011/DefaultLite.aspx?Id=3\&DocId=30243678>.

Wang, F. 2006. Quanttitative Methods and Applications in GIS. Abingdon: Taylor \& Francis, 304 p. ISBN 9780849327957.

Wang, T. A.; McTernan, W. F. 2002. The development and application of a multilevel decision analysis model for the remediation of contaminated groundwater under uncertainty, Journal of Environmental Management 64: 221-235. DOI: https://doi.org/10.1006/jema.2001.0470.

Weihe, G. 2005. Public-private partnerships: addressing a nebulous concept, in: Kaspersen, L. B. (Ed.), 10th International Research Symposium on Public Management (IRSPM X). Copehnagen: International Center for Business and Politics Copenhagen Business School, 29 p. ISBN 8791690161.

Wilson, M. 2011. The Park Is Elevated. Its Crime Rate Is Anything But. The New York Times, [žiūrèta 2016-02-11]. Prieiga per internetą: <http://www.nytimes.com/2011/06/11/nyregion/thehigh-line-park-is-elevated-its-crime-rate-is-not.html>.

Zaleckis, K.; Kamičaitytè-Virbašienè, J.; Matijošaitienè, I. Using space syntax method and GIS-based analysis for the spatial allocation of roadside rest areas, Transport 30: 182-193. DOI: https://doi.org/10.3846/16484142.2015.1045026.

Zavadskas, E. K.; Kaklauskas, A. 1996. Pastatu sistemotechninis įvertinimas. Vilnius: Technika, 275 p. ISBN 9986052823.

Xiaoling, Z.; Huan, L. 2018. Urban resilience and urban sustainability: What we know and what do not know? Cities 72: 141-148. DOI: https://doi.org/10.1016/j.cities.2017.08.009. 
Y1ldı, N.; Tüysüz, F. 2018. A hybrid multi-criteria decision making approach for strategic retail location investment: Application to Turkish food retailing, Socio-Economic Planning Sciences. DOI: https://doi.org/10.1016/j.seps.2018.02.006.

Кремер, Н. Ш. 2003. Теория вероятностей и математическая статистика [Kremer, N. S̆. Tikimybių teorija ir matematinė statistika]. Москва: ЮНИТИ. 573 с.

Завадскас, Э. К. 1987. Комплексная оиенка и выбор ресурсосберегающих рещений в строительстве [Zavadskas, E. K. Resursų taupymo sprendimų statyboje kompleksinis ịvertinimas ir parinkimas]. Вильнюс: Мокслас, 212 с. 



\section{Autoriaus mokslinių publikacijų disertacijos tema sąrašas}

\section{Straipsniai recenzuojamuose mokslo žurnaluose}

Bielinskas, V.; Burinskienè, M.; Podviezko, A. 2018. Choise Of Abandoned Territories Conversion

Scenario According to MCDA Methods. Journal of Civil Engineering and Management, 24(1), 79-92. ISSN 1392-3730/eISSN 1822-3605 (Clarivate Analytics Web of Science).

Burinskienè, M.; Bielinskas, V.; Podviezko, A. 2017. Evaluating the significance of criteria contributing to decision-making on brownfield land redevelopment strategies in urban areas. Sustainability, 9(1), 1-17. ISSN 2071-1050 (Clarivate Analytics Web of Science).

Burinskienè, M.; Lazauskaitè, D.; Bielinskas, V. 2015. Preventive indicators for creating brownfields. Sustainability, 7(6), 6706-6720. ISSN 2071-1050 (Clarivate Analytics Web of Science).

Bielinskas, V.; Burinskienė, M. 2016. Apleistų miesto seniūnijų teritorijų koreliacinè analizè. Vilniaus miesto atvejis. Journal of Science - future of Lithuania (K. Šešelgis Readings), 8(1), 3847. ISSN 2029-2341 print, ISSN 2029-2252 online.

Bielinskas, V.; Burinskienė, M. 2015. Apleistų teritorijų konversijos igyvendinimo galimybės Lietuvos miestuose. Journal of Science - future of Lithuania (K. Šě̌elgis Readings), 7(1), 30-39. ISSN 2029-2341 print, ISSN 2029-2252 online. 


\section{Straipsniai kituose leidiniuose}

Bielinskas, V. 2017. Geostatistical analysis of urban brownfields in Liverpool city. $10^{\text {th }}$ International Conference "Environmental Engineering”, April 27-28. p. 1-10. eISBN 9786094760440, eISSN 2029-7092. (ISI Proceedings).

Bielinskas, V.; Palevičius, V.; Burinskienè, M. 2015. Assessment of neglected areas in Vilnius city using MADM and COPRAS methods. Procedia Engineering. Innovative solutions in construction engineering and management. Flexible approach: Operational Research in Sustainable Development and Civil Engineering - meeting of EURO working group and $15^{\text {th }}$ German Lithuanian - Polish colloqui. Amsterdam: Elsevier Science Ltd., 122(2015), 29-38. ISSN 18777058 online. (ISI Proceedings). 


\section{Summary in English}

\section{Introduction}

\section{Problem formulation}

The assessment and use of brownfield areas (hereinafter referred to as BF) appears as one of the most relevant problems encountered in planning the urban environment, new types of construction and areas meeting the needs of the population. As for Lithuania and Eastern European countries, the BF is often regarded as the legacy of the Soviet regime. Such an area, demanding on potential additional financial resources for its cleaning and preparing for use, in most of the cases, is unattractive to new investors.

Within different historical periods, European cities encountered the problems of area regeneration. The natural urban framework and the formation of a public space system had a strong impact on the decisions made (Garcia-Ayllon 2018; Urbonaite 2012). Compared to other European countries, Lithuania suffers from a lack of the integrated approach of architects, municipalities and city planners to urban development processes, its coherence and ecology (Mekdjian 2018; Sassi et al., 2009).

Planning urban development and management often addresses the problems associated with abandoned areas that are no longer used for their intended purpose. (Matulevičius, Šliogerienė 2011). In Vilnius City General Plan till 2015 (Vilniaus miesto savivaldybės... 2007) there are city planning solutions that cover territories for change of initial purpose in future. Those territories cover 614 ha, i.e. $1.53 \%$ of the total area of the city (Leitanaite 2007). In the central part of the city, such areas amount to approximately 120 ha. (Blotnys 2013). 
There is a lack of norms and recommendations for management of BF among the laws and legislations in Lithuania. An overview of the information sources from Lithuania and

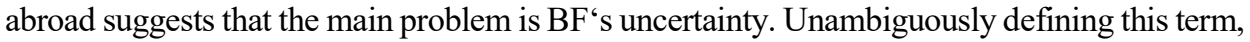
it is impossible to objectively determine the potential of these territories, to identify threats and to provide reasoned solutions.

After defining the $\mathrm{BF}$, it is expedient to set objective criteria and their individual weights (coefficients). The numerical value of these criteria should help to assess the potential, necessity and priority of possible BF scenarios for changes in land purpose (Laprise et al 2018). The objects of changes in the purpose of areas are the entire public infrastructure in the urban environment and cover the re-organizational planning, regulation and implementation of roads, streets, separate transport, residential, industrial and other districts or individual territorial units.

\section{Relevance of the thesis}

Cities are not a static finite form. The city, as an urban unit, is characteristic of the continuity of different creative processes in terms of economic, social and ecological aspects. The coherence of these components determines the quality of life and shapes the characteristics of the aesthetics of the urban environment. Variations in socio-economic, socio-cultural and geo-ecological dimensions form the eternal cycle, the criterion of which is the urban environment (Griškevičiūtè-Gèčienè, Griškevičienė 2016; Mozuriunaite 2016). Therefore, in order to avoid local and global economic, cultural and ecological threats, changes in urban development are an inevitable process.

The international approach to working out solutions for BF areas has grown for more than 40 years - since 1970 when the issue of using BF areas has gained weight in the political agenda. Currently, these methods are closely linked to a more general agenda for the sustainable development of cities and regions and must be applied in accordance with the present standards and changed urban environments.

The brownfields in industrial areas are the most vulnerable from an ecological point of view and require particular attention. Adapting such territories to meet modern needs should reduce the extent of urban development and protect natural resources. The upcoming function of these areas must be determined so that following changes in land purpose the territory should be coherent with the urban and functional urban structure (Matulevičius and Šliogerienè 2011).

At this time, more than $1200 \mathrm{BF}$ areas are counted in Vilnius. Overall, these zones occupy more than 1090 ha within the administrative boundaries of Vilnius city, i.e. about $2.7 \%$ of the total urban area. Such areas should be accepted as an untapped urban resource that can improve the quality of life and the multi-layered urban environment.

\section{The object of the thesis}

The object of the research is a system of indicators describing characteristics and use of urban brownfields.

\section{The aim of the thesis}

The aim of thesis is to scientifically justify and propose a model for the assessment of urban abandoned land use change scenarios that can be used to select the most appropriate brownfield scenario. 


\section{The tasks of the thesis}

The following objectives are being solved in order to achieve the aims of the thesis:

1. To analyse references aimed at identifying the threats of using BF areas in Lithuania and foreign countries, at proposing solutions and methods of use and at summarizing concepts.

2. To create a database (DB) of numerical values of indicators describing the characteristics of brownfields using geographic information system (GIS) and statistical methods.

3. To set the key criteria for different cases of scenarios for changes in the purpose of brownfields with reference to the created database of criteria.

4. To calculate quantitative parameters for brownfields applying Multi-Attribute Decision-Making (MCDM) methods, and, based on the made calculations, to develop scenarios for implementing changes in the purpose of brownfields.

5. To adapt and verify developed brownfield scenarios in the specific areas of Vilnius city neighbourhoods.

\section{The research methodology}

The thesis applies to theoretical research analysis, spatial correlation analysis, the expert method, multi-attribute decision making (TOPSIS, SAW, COPRAS, DELFI, EDAS) methods, quantitative and spatial data linking and merging methods.

The application of research analysis has assisted in presenting an overview of scientific literature, European Commission-provided and other legal publications as well as thesis-related materials produced by real estate developers.

By applying a natural research method, the number, size and characteristics of the $\mathrm{BF}$ areas, which measurements were not described in official documents, of Vilnius city were defined. Quantitative and spatial data linking and merging methods added information to the geospatial database of brownfields and calculated evaluation criteria for brownfields employing different normalization options.

The geostatistical method was applied using GIS software ArcGIS 10.0 and the Python programming language.

With reference to the multi-attribute decision making methods developed and advanced by VGTU scientists and to the practice of applying the expert evaluation method introduced in scientific literature, the criteria and their weights of brownfields have been calculated. Based on DSPM (TOPSIS, SAW, COPRAS, DELFI and EDAS), the correlation of the criteria describing brownfields has been assessed and the impact made by changes in the purpose of implementing scenarios has been examined.

By employing these methods, a strategy for selecting city neighbourhoods has been proposed, which aims to select the most appropriate parts of the city for executing specific scenarios for changes in the purpose of $\mathrm{BF}$ areas. 


\section{Scientific novelty of the thesis}

When preparing the thesis, the following results, new and significant to the science of civil engineering, were obtained:

1. A system for assessment criteria for BF areas which can be used at the stage of urban strategic planning, has been developed

2. With reference to multi-attribute decision-making methods, the numerical estimates of the weights of criteria have been calculated, which allowed forming a priority line of city neighbourhoods thus proposing a unique system for changes in the purpose of brownfields in Vilnius.

3. Three original conceptual models for implementing scenarios for changes in the purpose of brownfields have been developed can be applied in the case of any city.

\section{Practical value of the research findings}

The criterion system describing brownfields and presented in the doctoral thesis can be employed at the stage of urban complex planning when preparing plans for strategic and urban development. The application of the above introduced system for spatial planning experts and real estate developers provides favourable conditions for assessing social, urban, economic and natural criteria. Based on the results of this assessment, a calculation model has been proposed, which allows determining scenarios for changes in the purpose of brownfields and alternatives for developing separate parts of the city. The system for criteria assessing brownfields has been created and described and is a suitable tool for use in the biggest cities of Lithuania and other European countries.

The principle of the operating algorithm is based on the combined application of multi-attribute methods. The employment of different multi-attribute decision-making methods to simultaneously perform the same task and the aggregate evaluation of results is a unique achievement in the discourse of research literature on area planning and development in Lithuanian and foreign territories. The experience of Lithuanian spatial planning shows that such method will allow a more effective evaluation of the existing threats of brownfields, finding the most appropriate parameters for changes in the purpose of $\mathrm{BF}$ areas and optimizing scenarios for the management of these urban areas.

According to the unique methodology proposed in the thesis, the importance of each criterion and the correlation between the environmental characteristics of urban territorial communities and the spread of brownfields in them have been evaluated. Scenarios for changes in the purpose of brownfields are determined according to the areas occupied by the functional zones predominating in the city. In the case of Vilnius, six principal scenarios for changes in the purpose of brownfields have been specified.

\section{Defended statements}

1. Urban brownfields fall into groups according to the geographical boundaries of the urbanized areas, and therefore simulating changes in the purpose of brownfields can be induced systematically combining urban data according to territorial units. 
2. Scenarios for changes in the purpose of brownfields can be selected on the basis of the unique characteristics of the examined area. They are characterized by the criteria identified as the keys in each scenario.

3. Due to the uncertainty of the concept of the brownfield and different detection manner, the number of urban brownfields is higher than that provided in the official planning documents.

\section{Approval of the research findings}

Seven scientific publications were published on the subject of the thesis: three in scientific journals, included in the Clarivate Analytics Web of Science database (Burinskienè et al. 2015, Burinskienè et al. 2017, Bielinskas et al. 2018), Two - in a peer-reviewed scientific journal (Bielinskas and Burinskienè 2014 ir Bielinskas and Burinskienè 2015), one - in international conference, included in the ISI Proceedings database (Bielinskas 2017), one - in other international conference (Bielinskas et al. 2015).

The results of the research conducted in this thesis were published in four scientific conferences in Lithuania and abroad.

- Conference for Junior Researches Science is the Future for Lithuania in 2015, Rokiškis (Bielinskas and Burinskienè 2015).

- Conference for Junior Researches Science is the Future for Lithuania in 2016, Vilnius (Bielinskas and Burinskienè 2016).

- International conference $15^{\text {th }}$ German-Lithuanian-Polish Colloquium ORSDCE 2015; 2015, Poznań, Poland (Bielinskas et al. 2015);

- $10^{\text {th }}$ International Conference - Environmental engineering; 2017 Vilnius, (Bielinskas 2017).

\section{The structure of the thesis}

Thesis consists of introduction, three chapters, general conclusions, list of references, list of scientific publications by the author on the topic of the dissertation.

The scope of thesis is 149 pages excluding annexes, 41 numbered formulas, 27 tables and 50 pictures. 199 scientific sources were used while preparing the thesis.

\section{The overview of the procedures of chaning purpose of brownfields in Lithuania and foreign countries}

Since the beginning of the sudden urbanization process, most cities worldwide have faced the unprecedented occurrence: the number of the urban unexploited areas started growing despite the fact that these territories, in regard of the dislocation aspect, were situated in the attractive places of the city; however, from an ecological point of view, it was not useful and became threatening because of the risen risk of pollution. Most of real estate development planners felt safer investing in cheaper land in peripheral urban areas rather than in creating the new destination infrastructure within cities. Up to the year 2014, there were made no agreements between European countries and Lithuania. That is why by defining the exploratory problem, first of all, we have to define brownfields of a city as the main object of the research. 
Based on search for foreign literature, different approaches to the issues of urban brownfields can be observed. So far, there has been no general definition of the brownfield and no general agreement on how to deal with brownfields, non-functional and convertible areas in the EU Member States. Practice shows that Private-Public Partnership (PPP) is the most financially attractive way to manage brownfields. The least costly regeneration processes themselves require regenerated urban brownfields. The studies presented in the paper demonstrate that potentially economically feasible territories occupy the two-thirds of all brownfields.

Until 2014, no agreements were reached at European and Lithuanian levels. Therefore, for determining the research problem, defining urban brownfields as the main object of research is of utmost importance. Based on research into Lithuanian literature (Leitanaite, Stauskis, Urbonaite, Butkus, etc.), lack of good practise, available open data and the experience of the investigated issues of urban brownfields cause the obstruction of designing guidelines for strategic urban planning in the common case.

Considering a full knowledge of foreign and Lithuanian research literature on urban brownfields, it can be concluded that, in order to effectively manage brownfields, it is necessary to define the analyzed area and the possible uses of the territory. The thesis illustrates that Vilnius city is divided into 20 neighbourhoods expressed by a unique set of parameters. Further analysis was performed based on this scale.

An overview of research literature presented in this chapter has showed that more attention to the effective secondary use of the urban brownfield, in respect of local strengths, weaknesses and threads, is required.

Taking into account the practice of foreign countries applying the definition of the brownfield, the threats posed by urban brownfields in Lithuania and the characteristics of brownfields described in research literature, the author states that the formerly developed and at least one-year unexploited buildings and structures (if any) or their residues in brownfields (not necessarily polluted) do not meet the minimum requirements for exploiting them at present.

\section{Geostatistical analysis of brownfields in different districts of the city}

Vilnius is a Lithuanian city with the largest population and the biggest amount of investment in real estate development, including new buildings deployed across the whole area of the city. Thus, three issues of the urban brownfield can be identified. The first one is lack of available data on the complex evaluation of the scope of brownfields (this is a reason why the municipality cannot prepare optimal guidelines for strategic urban planning in Vilnius). The second is the promotion of intuitive planning performed considering a shortage of information about the area and neglecting multiple criteria representing different aspects of such territory. The third issue is the absence of the priority system among neighbourhoods at the prioritized stages of the redevelopment processes of urban brownfields. By solving this problem, we have an algorithm that allows investigating the current status of the urban brownfield, evaluating multiple criteria considering their importance, prioritizing city neighbourhoods, assessing the most important criteria for a specific scenario for changes in 
land use and selecting the optimal location or neighbourhood for the preferred scenario for changes in land use or a mix of those.

The conducted research shows that a total of BF areas cover 1090 ha, i.e. $2.7 \%$ of the total area of the city, and this value varies. Only about $17 \%$ of the total BF area is recorded in urban zones. These territories spatially constitute habitats that can be analyzed as individual subsets. (Fig. S.2.1).

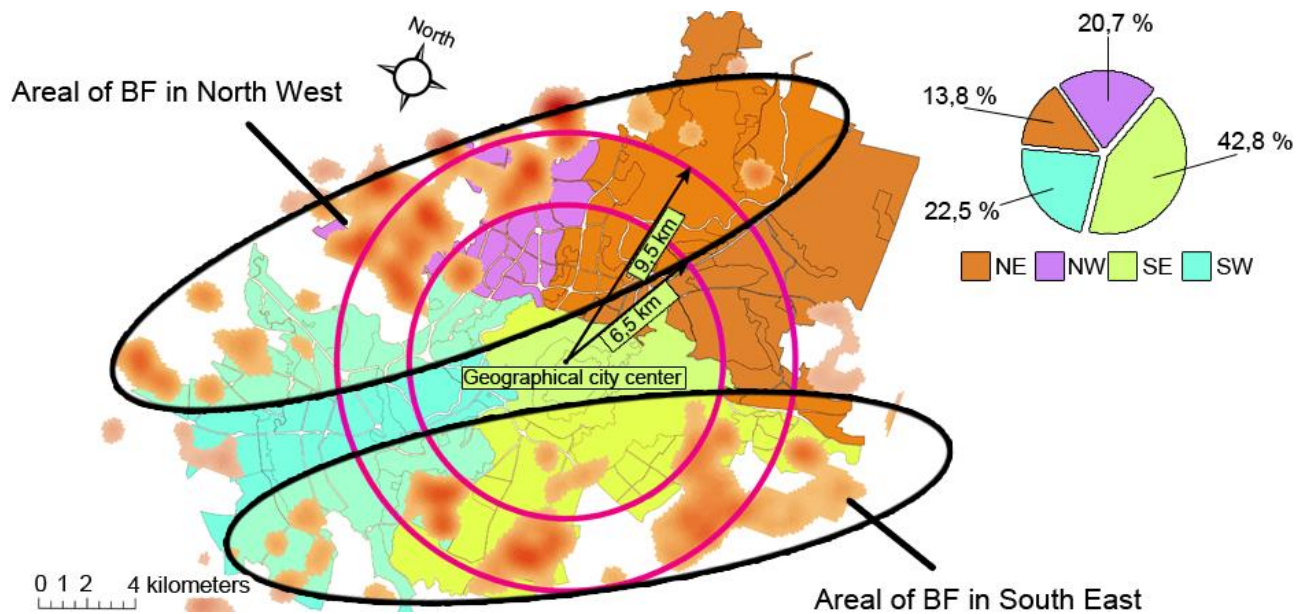

Fig. S.2.1. The areas of brownfields according to the number in the zones of South West, South East, North East and North West in of Vilnius city (created by author)

According to the estimates, during the last year, 230 real estate projects in Vilnius city using BF were implemented. 85 units (i.e. 37\%) are housing, 10 units (i.e. 4.3\%) are the objects of infrastructure, 41 units (i. e. 17.8\%) make commercial real estate, 70 buildings undergo refurbishment (i. e. 30.4\%) and 23 units (i. e. 10\%) are the buildings of public use. When making use of BF resources, mixed-purpose areas in the central part of the city that faced former dominating commercial projects of real estate development have been developed. The urban peripheral zone has involved intensive construction projects of medium and high-density housing development.

The made calculations have revealed that a varying functional type makes a different impact on BF management: some functions of the areas lead to an increase in brownfields while other functions contribute to their decline. Among the functions that make up a facilitating impact on brownfields in neighbourhoods, the business and industrial territory $(R=0.45)$ appears as the most distinguished functional type. The areas of such destination are generally mono-functional.

A strong relationship between the number of BF areas and the distance of these areas from the city centre has been discovered. The relationship is defined as correlation coefficient $R$ linking these two values. The estimated value of the correlation coefficient between BF quantity and the distance from the city centre moves toward the peripheral part of the city forming the boundary of up to $6,5 \mathrm{~km}$, which is 0.93 . While maintaining 
this direction from the boundary of $9.5 \mathrm{~km}$ to the edge of the administrative boundary of the city, the value of the correlation coefficient reaches 0.89 .

The spread and volumes of BF areas visually are greater than those declared in the solutions for the general plan. 23 various-size brownfields are found in a single neighbourhood in Vilnius. Depending on functional variance, the average size of the BF differs up to 40 times. 305.1 ha of brownfields are calculated in the peripheral parts of the city, which makes nearly $2.4 \%$ of the total peripheral part of Vilnius. An average area of a single brownfield makes 0.23 ha more than that in the inner part of the city.

It is estimated that the area of the potential concentrated development zone in Vilnius makes $3.43 \%$ of the total area of the whole city. In comparison, BF areas occupy 1089.91 hectares, i.e. $2.66 \%$. BF areas in the areas of the potential concentrated development zone occupy only 66.28 ha, i.e. $6.31 \%$, which shows that the geographical distribution of brownfields, a potential threat to the social environment and their ecological impact on urban development policies will not be overlooked for the next 25 years.

The examination of economic environmental factors in Liverpool has pointed out a negative causal link between retail transactions and the number of BF areas taking into consideration time perspective. Such relationship is expressed as the correlation coefficient and is equal to 0.72. This shows that investment in the urban economic environment by creating additional jobs and shopping sites constitutes a barrier to BF spread and ingrain. Therefore, the promotion of economic activities in the concentrated areas of BF areas and brownfields must be regarded as a planning priority.

The results of geostatistical analysis have showed that the BF is a typical different internal and external environment that can be expressed in terms of quantitative and qualitative criteria. Because of a shortage of historical data, taking into account functional zones dominant in the city and the multi-functionality of Vilnius areas, 6 possible scenarios for changes in land purpose of brownfields have been defined (Table S.2.1).

Table S.2.1. Scenarios $T_{i}$ for changes in the purpose of brownfields

\begin{tabular}{|l|l|l|l|}
\hline Scenario & $\begin{array}{l}\text { New possible land purpose } \\
\text { of BF }\end{array}$ & Scenario & $\begin{array}{l}\text { New possible land purpose of } \\
\text { BF }\end{array}$ \\
\hline$T_{1}$ & Green areas & $T_{4}$ & Industrial area \\
\hline$T_{2}$ & Commercial areas & $T_{5}$ & Residential area \\
\hline$T_{3}$ & Recreational activity area & $T_{6}$ & City reserve \\
\hline
\end{tabular}

Defined directions $T_{i}$ to BF scenarios for changes in land purpose is the result of implementing the urban development strategy and making use of the existing BF areas. The results of geostatistical analysis have showed that the BF can be classified according to the priority, location and other typical characteristics. As regards the existing needs and priorities of the city in different territorial units, a heterogeneous social and economic environment characterized by the qualities of the terrain and changes in land purpose of brownfields must be created considering the principles of the effective strategy for urban development (Fig. S.2.2). 


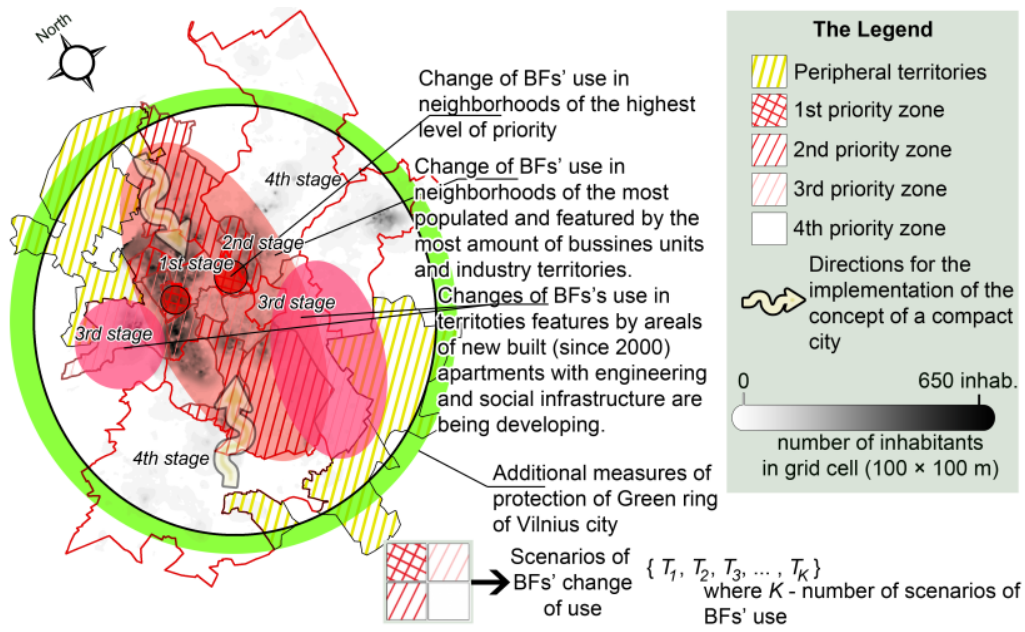

Fig. S.2.2. A theoretical model of the strategy for changes in the purpose of brownfields in Vilnius city (created by author)

The BF strategy provides that changes in land purpose and operations cover 4 stages. The first stage includes central urban areas where the $\mathrm{BF}$ could most of all contribute to implementing the compact model of the city. The second stage embraces the implementation of BF changes in land purpose pursued in the neighbourhoods that are mostly densely populated and have the highest volume of business and industrial territories. In the case of Vilnius, these are the areas around the city with the high intensity of development and the territories away from the city centre (Fig. S.2.3).

The third stage includes operations performed in the areas of new construction where the engineering and social infrastructure is not fully developed. At the fourth stage of the strategy, BF changes in land purpose are observed in the peripheral part of the city where the need for changes in land purpose is reduced.

\begin{tabular}{|c|c|c|c|c|}
\hline 1st stage & 2nd stage & 3rd stage & 4th stage & Priority approach \\
\hline $\begin{array}{c}\text { Territories with the } \\
\text { largest criminogenic } \\
\text { activity }\end{array}$ & Central city areas & $\begin{array}{l}\text { Industry areas } \\
\text { remoted further from } \\
\text { the city center }\end{array}$ & $\begin{array}{l}\text { Green Ring protection } \\
\text { by implementing } \\
\text { change of BFs' use to } \\
\text { green zones }\end{array}$ & Social approach \\
\hline $\begin{array}{l}\text { Green Ring protection } \\
\text { by change of BF's use } \\
\text { to green zones }\end{array}$ & $\begin{array}{l}\text { Industry areas } \\
\text { remoted further from } \\
\text { the city center }\end{array}$ & $\begin{array}{l}\text { Developing of } \\
\text { recreational areas, } \\
\text { sport grounds and } \\
\text { parks by implementing } \\
\text { change of BFs' use }\end{array}$ & $\begin{array}{c}\text { Territories with the } \\
\text { largest criminogenic } \\
\text { activitys }\end{array}$ & $\begin{array}{l}\text { Ecological approach } \\
\text { (2nd concept })\end{array}$ \\
\hline Central city areas & $\begin{array}{l}\text { Industry areas } \\
\text { remoted further from } \\
\text { the city center }\end{array}$ & $\begin{array}{l}\text { Change of BFs' use to } \\
\text { multifunctional areas } \\
\text { in central areas of } \\
\text { territorial communities } \\
\text { (neighborhoods) }\end{array}$ & $\begin{array}{l}\text { Development of } \\
\text { engineering and } \\
\text { social infrastructure in } \\
\text { recreational space } \\
\text { access areas }\end{array}$ & $\begin{array}{l}\text { Economical approach } \\
\text { (Real estate developers } \\
\text { and private capital) } \\
\text { (3rd concept) }\end{array}$ \\
\hline
\end{tabular}

Fig. S.2.3. A concept of brownfield development (created by author) 
Depending on the future prospects of the city, the BF strategy for changes in land purpose may be implemented by following the concept meeting the needs of the city. In the case of Vilnius, 3 main priorities in the direction of development can be provided (Fig. S4).

The BF clear-out concept encourages paying attention to the local level and to the social and economic problems of the city (for example, crime, preservation, the protection of recreation spaces ensuring the needs of territorial communities, etc.). These concepts are recommendatory in nature and can be modified according to the characteristics and planning objectives of each city.

\section{The assessment of scenarios for changes in the purpose of urban brownfields}

The third section discusses brownfields (business object), their potential scenario for changes in land purpose (process) and their impact on the location in the city (location). In accordance with the first stage, a hierarchical index system for BF areas consisting of the primary chain of 152 different criteria has been formed. Following the completion of the analysis of these criteria according to the type of exposure, behaviour and expert evaluation, 15 of the prior criteria have been selected for further calculations. Under different economic, social, urbanistic and physical conditions, they can lead to the emergence of BF areas or an increase in damage to the environment (Table S.3.1).

Table S.3.1. The calculated weights of the most significant (final) criteria for the initial brownfields in groups $C_{i}$

\begin{tabular}{|c|c|}
\hline \multicolumn{2}{|c|}{ Groups of attributes } \\
\hline$C_{E}$ & $C_{S}$ \\
\hline $\begin{array}{l}\text { Relationship between property prices in the } \\
\text { municipality and adjacent neighborhoods } \\
\left(Q_{j}=0,079\right)\end{array}$ & Long-term unemployment rate $\left(Q_{j}=0,098\right)$ \\
\hline Cost of new rental estate $\left(Q_{j}=0,085\right)$ & Poverty level $\left(Q_{j}=0,099\right)$ \\
\hline Infrastructure investments $\left(Q_{j}=0,099\right)$ & $\begin{array}{l}\text { The actual average income of the population } \\
\left(Q_{j}=0,093\right)\end{array}$ \\
\hline $\begin{array}{l}\text { Spatial mismatch between workers and } \\
\text { workplaces }\left(Q_{j}=0,078\right)\end{array}$ & Level of crimes $\left(Q_{j}=0,093\right)$ \\
\hline \multicolumn{2}{|c|}{ Groups of attributes } \\
\hline$C_{U}$ & $C_{N}$ \\
\hline Number of empty sites $\left(Q_{j}=0,082\right)$ & Soil contamination $\left(Q_{j}=0,112\right)$ \\
\hline $\begin{array}{l}\text { Number of new building permits } \\
\left(Q_{j}=0,072\right)\end{array}$ & $\begin{array}{l}\text { Emissions level from local sources } \\
\left(Q_{j}=0,115\right)\end{array}$ \\
\hline \multirow{2}{*}{$\begin{array}{l}\text { Age of installation of infrastructure elements } \\
\left(Q_{j}=0,074\right)\end{array}$} & $\begin{array}{l}\text { Number of green areas per capita } \\
\left(Q_{j}=0,126\right)\end{array}$ \\
\hline & Vehicle emissions level $\left(Q_{j}=0,105\right)$ \\
\hline
\end{tabular}

These criteria, in line with their effects, are classified into the previous groups of effect. Ultimately, in light of the data collected from the city and its potential use, 18 alternative criteria have been formed and are used for calculation purposes at other stages (Fig. S5). 
The criterion system can be applied in practice as a basis for processing criteria, data monitoring and observing changes. At the second stage, the correlation analysis of criteria has been done. A positive or negative causal link between assessment criteria has been considered and estimated using the declared population, values and size of the BF in the neighbourhood. The employed method has demonstrated that the strategic planning level of the city as well as one or the other criterion can be directly related to the problem of the brownfield. At the third stage, expertise and Delphi methods have been applied thus assessing crucial criteria and their groups in each scenario for changes in land purpose of the city. The model for selecting a brownfield has been produced in accordance with the final stage using the most suitable parts of the city (neighbourhoods) in each event (combined, planning an area of varying use) of BF changes in land purpose. At this stage, for the same task, COPRAS, SAW, TOPSIS, DELPHI and EDAS methods have been applied.

Following the calculations of correlation analysis (the second stage), 13 of 18 criteria have been found resulting in a positive outcome for the neglected areas to spread. The biggest positive relationship between the BF and separate criteria has been calculated analysing unemployment levels, people living in poverty and crime rates in separate neighbourhoods.

Among the criteria which have the largest dependency, the unused land plots $\left(R_{i} \mid U_{l}=0.83\right)$ have been assigned group of urbanistic criteria. The strongest negative dependence characteristic of the group belonging to the economic criteria of the $C_{E}$ magnitudes for investment into the environment $\left(R_{i} \mid E_{l}=0.68\right)$ and the price of construction $\left(R_{i} \mid E_{2}=0.68\right)$. The determined ranks of criteria are represented in Table S.3.2.

Table S.3.2. Determined ranks of criteria evaluated by coefficient $R_{i}\left[C_{E, U, S, N}\right]$

\begin{tabular}{|c|l|c|l|c|l|c|l|}
\hline \multicolumn{2}{|c|}{$C_{E}$} & \multicolumn{3}{c|}{$C_{U}$} & \multicolumn{2}{c|}{$C_{S}$} & \multicolumn{2}{c|}{$C_{E}$} \\
\hline$R n$ & Criterion & $R n$ & Criterion & $R n$ & Criterion & $R n$ & Criterion \\
\hline 1. & $E_{1}(R=-0.68)$ & 1. & $U_{1}(R=0.83)$ & 1. & $S_{1}(R=0.85)$ & 1. & $N_{3}(R=0.77)$ \\
\hline 2. & $E_{2}(R=-0.68)$ & 2. & $U_{5}(R=0.68)$ & 2. & $S_{2}(R=0.83)$ & 2. & $N_{4}(R=0.53)$ \\
\hline 3. & $E_{3}(R=0.34)$ & 3. & $U_{4}(R=-0.29)$ & 3. & $S_{4}(R=0.83)$ & 3. & $N_{2}(R=-0.24)$ \\
\cline { 1 - 6 } 4. & \multirow{2}{*}{$E_{4}(R=0.22)$} & 4. & $U_{2}(R=0.11)$ & 4. & $S_{3}(R=0.71)$ & \multirow{2}{*}{4.} & \multirow{2}{*}{$N_{1}(R=0.15)$} \\
\cline { 2 - 5 } & 5. & $U_{3}(R=0,11)$ & 5. & $S_{5}(R=-0.16)$ & & & \\
\hline
\end{tabular}

The results obtained at the second stage show that the defined cause and effect relationship between the areas and the urban physical, social and ecological environment describing criteria in each neighbourhood has been found in scalar quantities.

The third stage has showed the most important criteria and the groups of criteria in the cases of different brownfields. The weights of the group of criteria for the scenario for BF changes in land purpose have been calculated using the DELPHI method (Fig. S6).

The obtained results have showed that roughly all groups of criteria are equally important while executing $\mathrm{BF}$ changes in land purpose replacing brownfields with green area $\left(T_{1}: C_{E}=20.25, C_{U}=26.5, C_{S}=23.0, C_{N}=30.25\right.$, standard deviation equals to 4.33$)$.

The adoption of making a decision on implementing residential changes in BF land use is the most important criteria for the social group $\left(T_{5}: C_{E}=22.17, C_{U}=24.08\right.$, $C_{S}=34.08, C_{N}=19.5$, standard deviation equals to 6.36). The calculation of the weights of the criteria in each evaluated group inside the brownfields is provided in Fig S.3.1. 
The obtained results highlight the secondary use of the following brownfields changing their land purpose in accordance with the guidelines in question:

1. The biggest impact of $\mathrm{BF}$ changes in land purpose on the solution to replacing $\mathrm{BF}$ areas with green areas is observed in the group of ecologic criteria.

2. Criteria for the economic group are featured having the highest impact on decision making while replacing BF areas with commercial areas within the city.

3. Criteria for the urbanistic group have the greatest impact on BF changes in land purpose replacing $\mathrm{BF}$ areas with sports courses or active leisure zones.

4. All but criteria for the social group have the biggest impact on decision making regarding $\mathrm{BF}$ changes in land purpose replacing BF areas with industrial zones;

5. Criteria for the social group have the greatest impact on BF changes in land purpose replacing BF areas with residential areas. The availability of education and child care institutions has the biggest impact on these criteria

6. Natural and urbanistic criteria have the greatest impact on BF areas left as a city reserve for future needs.
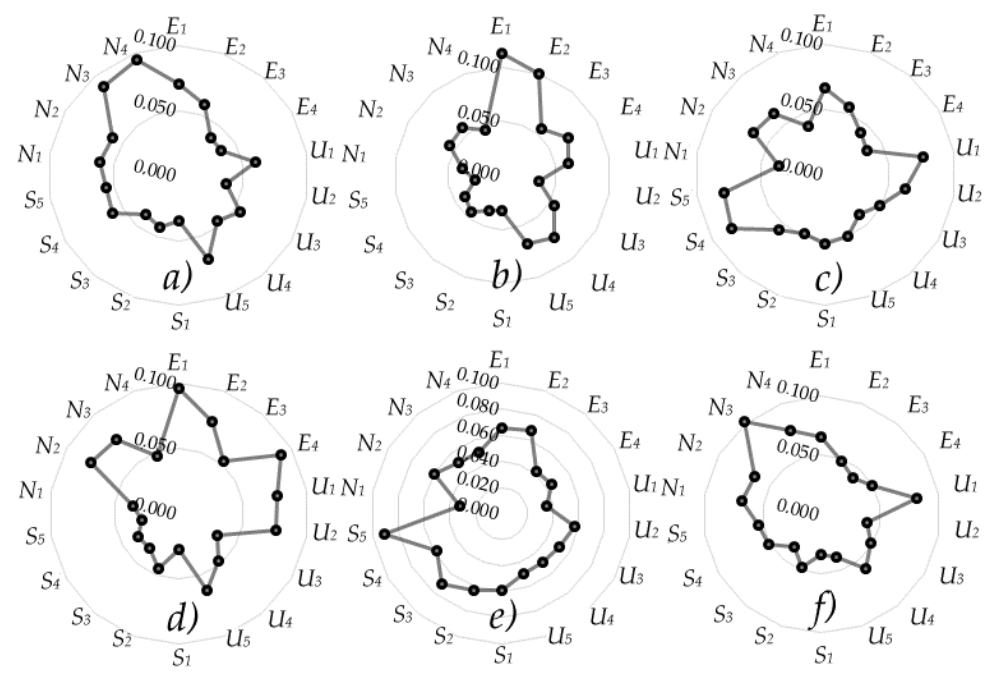

Fig. S.3.1.. The weights of individual criteria for each brownfield redevelopment scenario: a) $T_{1}$; b) $T_{2}$; c) $T_{3}$; d) $T_{4}$; e) $T_{5}$; f) $T_{6}$ (created by author)

The comprehensive application of different methods for COPRAS, TOPSIS, SAW and EDAS solving the same problem at the third stage and optimal city locations have been chosen for implementing different scenarios for BF changes in land purpose.

Thus, it is possible to assess the most appropriate parts of the city, to implement certain scenarios for changes in land purpose and to predict the most appropriate place for 
polyfunctional area formation using $\mathrm{BF}$ areas. For example, BF polyfunctional areas consisting of commercial, industrial and residential types of changes in land purpose as well as neighbourhood assessment are provided in Table S.3.3.

Table S.3.3. Appropriate possible scenarios $\bar{\omega}$ for changes in the purpose of brownfields according to neighbourhoods $D_{i \text {. }}$ (created by author)

\begin{tabular}{|c|c|c|c|c|c|c|}
\hline & \multicolumn{2}{|c|}{$T_{2}$} & \multicolumn{2}{c|}{$T_{4}$} & \multicolumn{2}{c|}{$T_{5}$} \\
\hline Rank & District & $\bar{\omega}$ & District & $\bar{\omega}$ & District & $\bar{\omega}$ \\
\hline 1 & $D_{8}^{I V}$ & 0.577 & $D_{12}^{I I I}$ & 0.510 & $D_{9}^{I I I}$ & 0.538 \\
\hline 2 & $D_{1}^{I I I}$ & 0.492 & $D_{3}^{I I}$ & 0.436 & $D_{14}^{I I I}$ & 0.513 \\
\hline 3 & $D_{3}^{I I}$ & 0.476 & $D_{13}^{I I}$ & 0.399 & $D_{10}^{I}$ & 0.508 \\
\hline 4 & $D_{13}^{I I}$ & 0.47 & $D_{20}^{I V}$ & 0.395 & $D_{6}^{I}$ & 0.488 \\
\hline 5 & $D_{17}^{I V}$ & 0.443 & $D_{1}^{I I I}$ & 0.382 & $D_{18}^{I V}$ & 0.487 \\
\hline
\end{tabular}

Notes: $D_{1}-$ Rasos, $D_{2}$ - Šeškinè, $D_{3}$ - Naujininkai, $D_{4}$ - Pilaitè, $D_{5}-$ Pašilaičiai, $D_{6}-\quad$ Šnipiškès, $D_{7}$ - Naujoji Vilnia, $D_{8}$ - Paneriai, $D_{9}$ - Justiniškès, $D_{10}$ - Viršuliškès, $D_{11}$ - Vilkpèdè, $D_{12}$ - Naujamiestis, $D_{13}$ - Verkiai, $D_{14}$ - Karoliniškès, $D_{15}$ - Žirmūnai, $D_{16}$ - Lazdynai, $D_{17}-$ Antakalnis, $D_{18} \quad$ - Fabijoniškès, $D_{19}-$ Žverrynas, $D_{20}-$ Senamiestis.

The obtained results show that mixed-use planning, including commercial, industrial and residential functions using the existing $\mathrm{BF}$ areas is the most suitable for exploitation in Rasos, Naujininkai and Verkiai neighbourhoods.

The detailed strategic urban planning of each scenario for BF changes in land purpose in Vilnius city is presented in the final section of the thesis (Fig. S.3.2).

The solutions to these strategies according to scenarios for BF changes in land purpose are provided below.

$\mathrm{BF}$ changes in land purpose replacing $\mathrm{BF}$ areas with green areas correpond to the scenario of Zverynas neighbourhood for brownfield changes in land purpose largely meets environmental parameters and provides the highest additional value in terms of ecology. Karoliniskes neighbourhood is the second most fitting location and goes next and Justiniskes is in the third position.

$\mathrm{BF}$ changes in land purpose replacing BF areas with commercial areas are directed towards the peripheral parts of the city. The criteria for the scenario for BF changes in land purpose mostly agree with economic environmental parameters for Paneriai neighbourhood. Rasos and Naujininkai neighbourhoods are in the other peripheral parts of the city, take the second and third positions and are suitable for this type of scenario.

$\mathrm{BF}$ changes in land purpose replacing $\mathrm{BF}$ areas with recreational areas can be described as development that is dispersed towards a nearby central part of the city located in both north-west and north-east peripheral areas of the city. This scenario for changes in land purpose is perfectly appropriate for social environmental parameters in Naujininkai, Pašilaičiai and Naujoji Vilnia neighbourhoods. Regarding the level of priority, the 
processes of the scenario for BF changes in land purpose must be started in Naujininkai and Pašilaičiai neighbourhoods, and then - in Naujoji Vilnia neighbourhood.

The change in land purpose of BF areas to industrial areas should be applied for Naujamiestis, Naujininkai and Verkiai neighbourhoods as priority. Based on the primary BF purpose and possible potential economy-wise changes in land purpose, this scenario for BF changes is primarily directed towards southeast starting in the BF areas located in Naujamiestis and Naujininkai neighbourhoods.
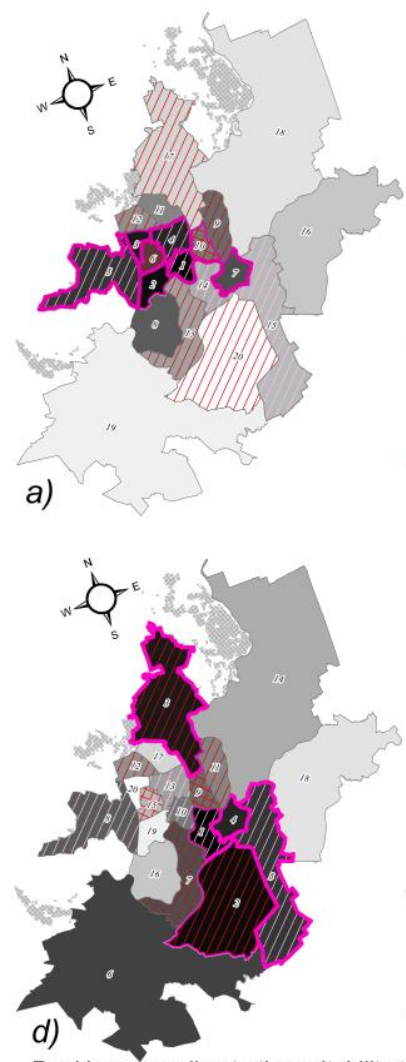

Ranking according to the suitability to implement changes

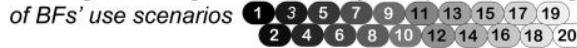

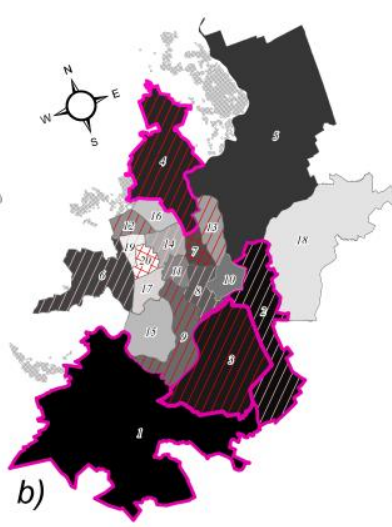

c)
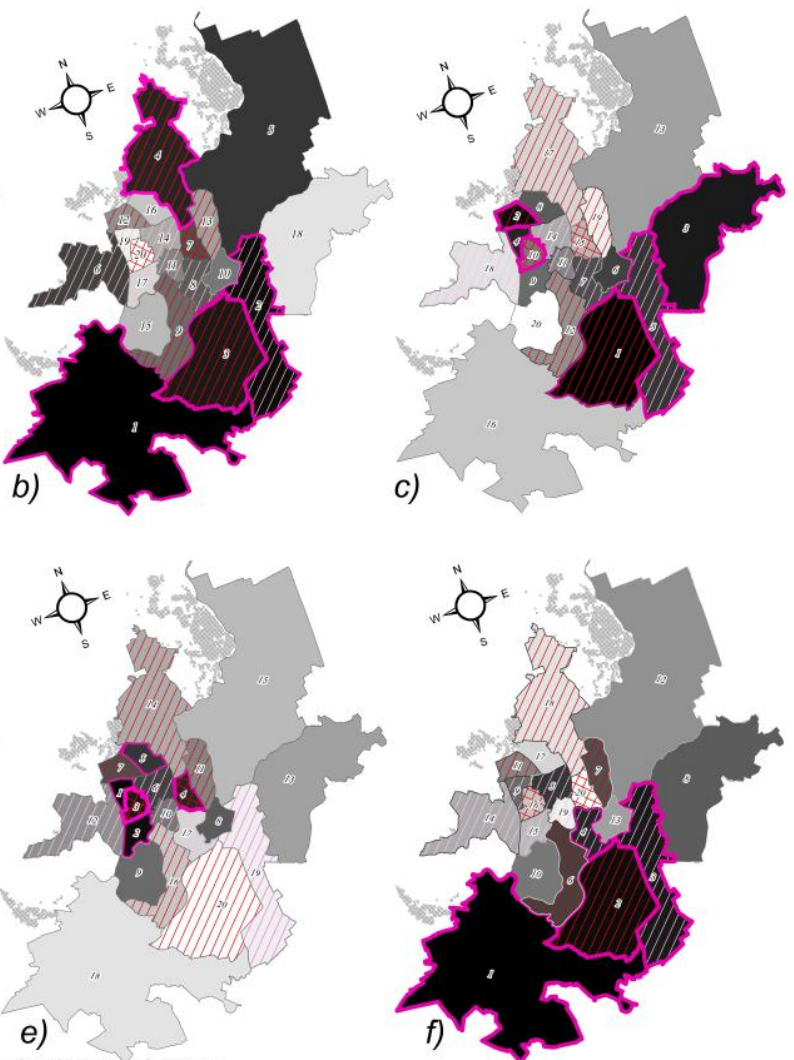

$87 \begin{aligned} & \text { 1st priority zone } \\ & \text { 2nd priority zone }\end{aligned}$

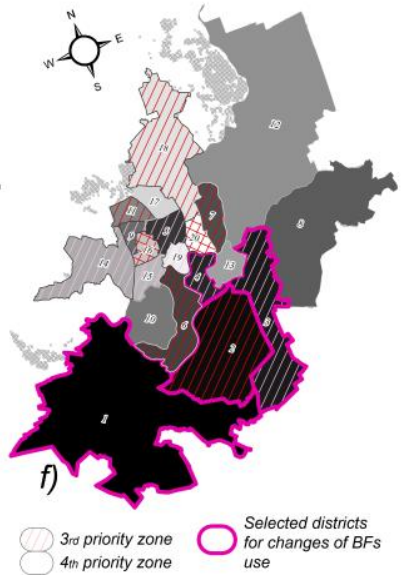

Fig. S.3.2. The implementation of the Strategy in different cases of scenarios $T_{i}$ for changes in

brownfield land purpose in Vilnius: a) to green area; b) to commercial area; c) to recreational activity area; d) to industrial area; e) to residential area; f) to city's land reserve (created by author)

$\mathrm{BF}$ changes in land purpose replacing BF areas with residential areas are directed towards north and north-east living areas that inherently have a large stacking rate. This scenario for changes in land purpose mostly fits social environmental parameters for 
Justiniškès, Karoliniškès, Viršuliškès and Šnipiškès neighbourhoods. Based on the degree of priority, Viršuliškès and Šnipiškès neighbourhoods must be paid most attention. This solution shows that residential areas in Vilnius city must concentrate on the formation of separate territorial communities and maintain convenient transport with the city centre.

The conservation of $\mathrm{BF}$ areas for the strategic needs of the city in the future is based on the solution to the temporary expansion of the urban area in BF halt that was economically useless at the time of research and did not agree with the required criteria for urban expansion. Thus, it would be useful to postpone the processes of changes in land purpose due to a growth in the natural city infrastructure for the next 5-10 years. The made calculations have showed that Paneriai, Naujininkai and Rasos neighbourhoods closely correspond with this kind of expansion criteria.

For editing primary BF criterion values, potentials and goals of the scenario for changes in land purpose, the model for selecting the BF has been used in the thesis and can be worldwide applied for any metropolitan city having a high rate of the BF and seeking to accomplish the strategic goals of the city.

\section{General conclusions}

1. The analysis of research literature and regulations has faced the problem of the purposeful use of brownfields. The implementation of the solution for changes in the purpose brownfields is burdened by the uncertainty of the territories boundaries and the inaccurate methodology for defining the ambiguities of the concepts found in different sources. Thus, the possibilities of changes in the purpose of brownfields have been evaluated only in local cases. Taking into account the results of the conducted analysis, the definition and typology of the brownfield has been proposed.

2. The examination of definitions, management practice and recommendations for brownfields has been done in research literature and regulations and demonstrates that from 152 different criteria combined according to the meaning and impact of use, a hierarchical criterion system has been created. The system identifies 15 finite criteria, according to which brownfields must be evaluated.

3. The performed geostatistical analysis has demonstrated that the spread of brownfields differs from the officially published data. Depending on functional heterogeneity observed in the separate neighbourhoods of the city, the area of the brownfield may vary up to 40 times.

4. Following the calculations of the method for modified spatial correlation analysis, a causal relationship between the distribution of brownfields and the values of the criteria describing them in a neighborhood has been proved. The key factors contributing to the spread of brownfields have been identified. The made calculations have showed that the criteria for the social group $(R=0,526)$ can be characterized as those having the most significant causal relationship. Among them, the strongest correlation was established between the criteria for the unemployment rate $(R=0,85)$, the poverty rate $(R=0,83)$ and the level of crime in the neighbourhoods $(R=0,83)$. 
5. The application of multi-attribute decision-making methods has identified individual criteria which help to make decision about implementation of different scenarios for changes in the purpose of BF areas. The calculations have demonstrated that the group of urban criteria had the strongest impact on decision making in order to change the purpose of brownfields $(\omega \%=26.7 \%)$. When changing land purpose replacing BF areas with the residential area, criteria for the social group become the most important $(\omega \%=34,08 \%)$.

6. By applying multi-attribute decision-making methods, a selection method was proposed to determine the most appropriate parts of the city for brownfield scenarios. The estimates defining the suitability of the scenario for changes in the purpose of the BF in the neighbourhood have been calculated. The research has disclosed that, in the case of changes in land purpose, when replacing brownfields with commercial areas in Vilnius city, Paneriai neighbourhood has been given the highest priority $(\omega=0.577)$, replacing brownfields with green areas, Zverynas neighbourhood appears in the best position $(\omega=0,577)$, replacing brownfields with the recreational area, Naujininkai neighbourhood goes first $(\omega=0,486)$, replacing brownfields for industrial purposes, Pilaite neighbourhood is the leader $(\omega=0,510)$ and replacing brownfields with the residential area, Justiniškès neighbourhood is in the most favourable position $(\omega=0,538)$. Brownfield changes used for developing the urban reserve area should concentrate in Paneriai neighbourhood $(\omega=0.589)$. The purpose of primary and secondary multi-storey area development has been found to be replaced with that of the mixed multi-functional zones.

7. On the basis of the dissertation, a unique methodology for evaluating the abandonment of urban brownfield areas has been developed, which allows. By adjusting the initial values of the indicators and their possible change of destination scenarios, adjust the model of brownfield selection and apply it to selected city. 


\section{Priedai $^{\star}$}

A priedas. Apleistų teritorijų automatizuotos klasterizacijos pagal apibrèžtus rodiklius algoritmo Python programinis kodas

B priedas. Apleistų teritorijų ankstyvujų vertinimo rodiklių ekspertinio vertinimo rezultatai

C priedas. Apleistų teritorijų rodiklių ekspertų vertinimo duomenys prieš rezultatu korekciją

D priedas. Daugiarodiklių sprendimo prièmimo metodụ vertinimo duomenys E priedas. Autoriaus sąžiningumo deklaracija

F priedas. Bendraautorių sutikimai teikti publikacijose skelbtą medžiagą mokslo daktaro disertacijoje

G priedas. Autoriaus mokslinių publikacijų disertacijos tema kopijos

\footnotetext{
* Priedai pateikiami pridètoje kompaktinejje plokštelëje.
} 
Vytautas BIELINSKAS

MIESTO APLEISTŲ TERITORIJŲ PASKIRTIES

KEITIMO SCENARIJUৃ VERTINIMAS DAUGIARODIKLIAIS

SPRENDIMŲ PRIĖMIMO METODAIS

Daktaro disertacija

Technologijos mokslai,

Statybos inžinerija (02T)

EVALUATION OF SCENARIOS FOR CHANGES

IN THE PURPOSE OF URBAN BROWNFIELDS APPLYING

MULTI-ATTRIBUTE DECISION MAKING METHODS

Doctoral Dissertation

Technological Sciences,

Civil Engineering (02T)

$20190107.14,5$ sp. I. tiražas 20 egz.

Vilniaus Gedimino Technikos Universiteto

leidykla „Technika“,

Saulètekio al. 11, 10223 Vilnius,

http://leidykla.vgtu.lt

Spausdino UAB „BMK leidykla“

A. Mickevičiaus g. 5, LT-08119, Vilnius. 